\title{
Władysław Grabski jako ekonomista (1874-1938)
}




\section{Ekonomia}

\section{Wtadystaw Grabski \\ jako ekonomista \\ (1874-1938)}

Janusz Skodlarski 
留 
Janusz Skodlarski - Uniwersytet Łódzki, Wydział Ekonomiczno-Socjologiczny, Instytut Ekonomii Katedra Historii Myśli Ekonomicznej i Historii Gospodarczej

90-214 Łódź, ul. Rewolucji 1905 r. 41

\title{
RECENZENT
}

Zdzisław Szymański

\author{
REDAKTOR WYDAWNICTWA UŁ \\ Joanna Balcerak
}

SKŁAD I ŁAMANIE

Eżbieta Potapiuk, Barbara Skodlarska

PROJEKT OKŁADKI

Stämpfli Polska Sp. z o.o.

Zdjęcie wykorzystane na okładce udostępnione przez Bibliotekę Narodową

- Zakład Informacji Naukowej

Wydrukowano z gotowych materiałów dostarczonych do Wydawnictwa UŁ

C Copyright by Uniwersytet Łódzki, Łódź 2015

Wydane przez Wydawnictwo Uniwersytetu Łódzkiego
Wydanie I. W.06843.15.0.M

Ark. druk. 9,0

ISBN 978-83-7969-621-5

e-ISBN 978-83-7969-643-7

Wydawnictwo Uniwersytetu Łódzkiego

90-131 Łódź, ul. Lindleya 8

www.wydawnictwo.uni.lodz.pl

e-mail: ksiegarnia@uni.lodz.pl

tel. (42) 6655863 


\section{Spis treści}

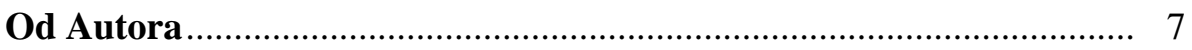

\section{Rozdzial I}

Wladysław Grabski (1874-1938)

\section{Rozdzial II}

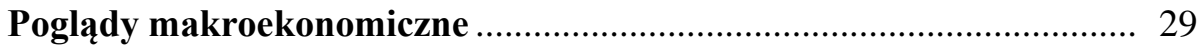

1. Systemy ekonomiczne ............................................................ 31

2. Determinanty dochodu narodowego .............................................. 34

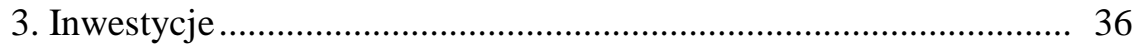

4. Rola czynnika pracy we wzroście gospodarczym .......................... 40

5. Państwo, budżet, podatki ............................................................... 44

6. System pieniężno-kredytowy ........................................................ 51

7. Cykle koniunkturalne. Kryzysy ekonomiczne …………….............. 55

8. Rozwój gospodarczy ………................................................... 78

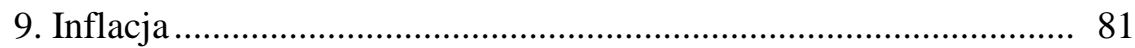

\section{Rozdzial III}

Polityka ekonomiczna

1. Przedmiot polityki ekonomicznej ................................................ 85

2. Kierunki rozwoju gospodarki polskiej.......................................... 87

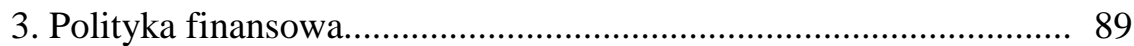

4. Polityka walutowo-kredytowa .................................................... 94

5. Polityka przemysłowa i inwestycyjna.............................................. 96

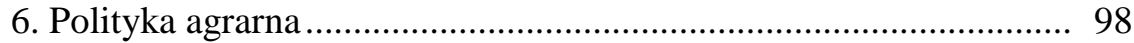

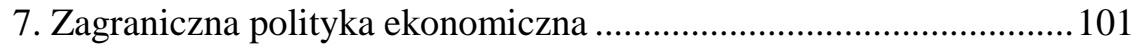

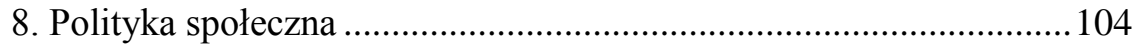




\section{Rozdzial IV}

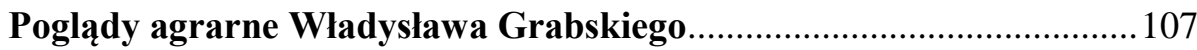

1. Podstawowe zasady ustroju agrarnego Polski .................................. 107

2. Wieś jako podstawa rozwoju społeczno-gospodarczego .................... 108

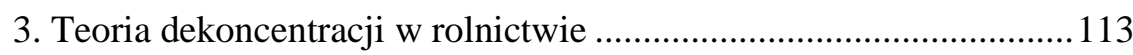

3.1. Wpływ zmian stosunków produkcji na strukturę agrarną ........113

3.2. Optymalny model struktury agrarnej....................................... 115

3.3. Postęp techniczny a struktura agrarna ...................................... 122

4. Przeludnienie agrarne. Reforma rolna. Parcelacja............................. 125

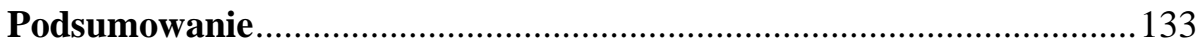

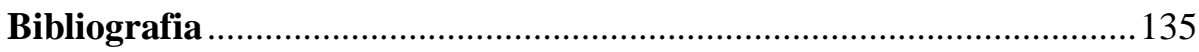

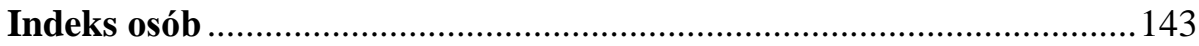




\section{Od Autora}

Władysław Grabski był wybitnym politykiem i reformatorem. Jego zasługi w dziele unifikacji i stabilizacji gospodarki polskiej po I wojnie światowej nie budzą dzisiaj żadnych wątpliwości. Najbardziej znane są dokonania Grabskiego dotyczące reformy walutowej. Literatura na ten temat jest bardzo bogata ${ }^{1}$.

Mniej znany jest natomiast Grabski jako uczony. Na uwagę zasługują przede wszystkim jego osiągnięcia $\mathrm{w}$ dziedzinie socjologii i ekonomii (do ekonomii zaliczam również prace z historii gospodarczej). Wyniki badawcze Grabskiego w zakresie socjologii wsi przedstawił, w solidnie udokumentowanej monografii, Kazimierz Korab ${ }^{2}$. Natomiast bogaty dorobek w dziedzinie ekonomii nie doczekał się dotychczas naukowej publikacji. Niniejsza praca ma na celu wypełnienie tej luki.

Głównym motywem w działalności publicznej i pracy naukowej W. Grabskiego była troska o przyszłość Polski. Jej niepodległość i poprawę bytu społeczeństwa miał zapewnić rozwój gospodarczy. Bezpieczeństwo kraju i pomyślność obywateli uzależniał Grabski przede wszystkim od rozwiązania problemów wsi: „Dla ogólnego postępu społeczeństwa, dla jego siły narodowej i państwowej, dla udoskonalenia społecznego i cywilizacyjnego koniecznym jest, by ogół ludności wiejskiej miał wysoki stopień niezależności gospodarczej oraz by w jego środowisku była znaczna ilość ludności zdolnej do wybijania się naprzód"3.

${ }^{1}$ Zob.: Z. Landau, J. Tomaszewski, Gospodarka Polski międzywojennej 1918-1939, t. 1, W dobie inflacji 1918-1923, Warszawa 1967; t. 2, Od Grabskiego do Pitsudskiego, Okres ożywienia koniunktury 1924-1929, Warszawa 1971; M. M. Drozdowski, Władysław Grabski, RzeszówWarszawa 2004; W. Pobóg-Malinowski, Najnowsza historia polityczna Polski, 1864-1945, t. 2, cz. 1, Londyn 1956. W wymienionych pracach zamieszczone są źródła i opracowania na temat polityki skarbowej i reform W. Grabskiego.

${ }^{2}$ K. Korab, Władystaw Grabski jako socjolog wsi, Warszawa 2004.

${ }^{3}$ W. Grabski, Historia wsi w Polsce, Warszawa 2004, s. 363. 



\section{Rozdział I}

\section{Wladysław Grabski (1874-1938)}

Władysław Grabski urodził się dnia 7.07.1874 r. we wsi Borów położonej w powiecie łowickim, w rodzinie ziemiańskiej, jako trzecie dziecko Feliksa i Stanisławy z Mittelstaedtów. Był młodszym bratem Stanisława (1871-1949) polityka, ekonomisty, publicysty i ideologa Narodowej Demokracji. Miał dwie siostry: Zofię (ur. w 1872 r., wybitna działaczka PPS) i Halinę (ur. w 1876 r., utalentowana pianistka) ${ }^{1}$.

Ród Grabskich, herbu Pomian, sięgał okresu średniowiecza. Pradziadek Władysława, Franciszek, utracił majątek w wyniku represji za udział w konfederacji barskiej (1768 r.). Dziadek Władysława, Andrzej Rafał Grabski, był już tylko dzierżawcą majątków w Śladkowie, Małachowicach i Rakowie. Ponownie posiadaczem stał się ojciec Władysława, Feliks Grabski, który nabył majątek w Borowie nad Bzurą. W 1859 r. przeprowadził uwłaszczenie chłopów w jednej z najuboższych wsi, należącej do jego majątku. W powstaniu styczniowym pełnił funkcję komisarza cywilnego ${ }^{2}$.

Ojciec zaszczepił Władysławowi szacunek do ziemi, wsi i włościan. Wzorując się na nim, jako kolejny właściciel majątku w Borowie, każdemu swemu robotnikowi rolnemu po przepracowaniu 10 lat przekazywał na własność 10 mórg ziemi ${ }^{3}$.

Feliks Grabski był nowoczesnym gospodarzem, cenionym przez ziemian i okolicznych chłopów. Interesował się historią i polityką. Podziwiał Stany Zjednoczone Ameryki Północnej. Przepowiadał utworzenie w przyszłości Stanów Europejskich. Był republikaninem i demokratą, nazywano go „chłopomanem", w przeciwieństwie do matki, która uchodziła za arystokratkę.

\footnotetext{
${ }^{1}$ M. M. Drozdowski, Władysław Grabski, Rzeszów-Warszawa 2004, s. 15.

${ }^{2}$ K. Korab, Władystaw Grabski jako socjolog wsi, Warszawa 2004, s. 14.

${ }^{3}$ J. W. Grabski, Blizny dzieciństwa, Warszawa 1971, s. 70.
} 
Władysław przejął po ojcu szacunek do chłopów. Jak pisał Jan Władysław, syn Władysława Grabskiego, podawał chłopom rękę na powitanie (ku zgorszeniu szlachty $)^{4}$. Feliks Grabski działał świadomie na rzecz jedności ponad podziałami społecznymi. Angażował się w sprawy ojczyzny, ale większe znaczenie przywiązywał do rzetelnej pracy i działalności publicznej na terenie gminy ${ }^{5}$.

Władysław Grabski postępował w swoim życiu i działalności zgodnie z zasadami wpojonymi mu przez ojca. Ideę niepodległości bardziej łączył z pozytywistyczną pracą niż z czynem zbrojnym.

Matka Władysława, Stanisława z d. Mittelstaedt, zajmowała się początkowym kształceniem dzieci. Korzystając z pomocy bon cudzoziemek i Polek guwernantek uczyła je czytać, pisać, dawała podstawy rachunków oraz języków obcych. Szczególną uwagę zwracała na naukę katechizmu i historii Polski. Zaszczepiała w nich patriotyzm i tradycje narodowe. Rodzina Mittelstaedtów pielęgnowała zwłaszcza kult powstań niepodległościowych. Przodkowie jej brali aktywny udział w powstaniu wielkopolskim (1848 r.) oraz w powstaniu styczniowym ${ }^{6}$.

W latach 1883-1892 Władysław uczęszczał do męskiego V Gimnazjum Filologicznego w Warszawie, podobnie jak jego starszy brat - Stanisław. W związku z edukacją dzieci matka zamieszkała z nimi w Warszawie. W rodzinie Grabskich przywiązywano dużą wagę do solidnego wykształcenia. Ojciec pozostał $\mathrm{w}$ Borowie, aby zarządzać majątkiem. Dochody $\mathrm{z}$ gospodarstwa przeznaczone były głównie na edukację dzieci. Siostra Władysława, Zofia Kirkor-Kiedroniowa (żona ministra przemysłu i handlu w rządzie W. Grabskiego - 1923-1925), wspomina: „ «Ostatnie bydlę wyprowadzę z obory, byleście się uczyli» - mawiał ojciec... Nie zapomniałam też słów Ojca, zwróconych do mych braci: «Pamiętajcie, żeby o was $\mathrm{w}$ gazetach pisano»... zawsze go pociągało, to jest by pracowali dla dobra publicznego, już nie w skromniutkim, prowincjonalnym zakresie, ale na donioślejszym dla Ojczyzny polu. Obok pracy społecznej - na równym poziomie stawiał ojciec tylko pracę naukową (o robieniu majątku nigdy z ust ojca żadnych pouczeń nie usłyszałam)"”.

W gimnazjum wraz z bratem organizował kółka samokształceniowe i należał do tajnej Centralizacji Związku Kółek Gimnazjalnych Królestwa Polskiego. Naczelnym hasłem programowym tej organizacji była walka o prawo ludu do awansu cywilizacyjnego i ochrona interesów ludzi biednych. Nierówności

\footnotetext{
${ }^{4}$ M. M. Drozdowski, op.cit., s. 16; K. Korab, op.cit., s. 14-15.

${ }^{5}$ K. Korab, op.cit., s. 15.

${ }^{6}$ M. M. Drozdowski, op.cit., s. 17; K. Korab, op.cit., s. 16.

${ }^{7}$ Cyt. za: K. Korab, op.cit., s. 16.
} 
społeczne i ekonomiczne w Królestwie Polskim skłoniły braci Grabskich i ich siostrę Zofię do wstąpienia do tajnych kółek socjalistycznych. Poznali oni i słuchali wykładów wybitnych socjalistów: Ludwika Krzywickiego i Edwarda Abramowskiego. W warszawskim mieszkaniu Grabskich odbywały się spotkania istniejącego od 1885 r. Uniwersytetu Latającego, którego wykładowcami byli m.in. Tadeusz Korzon, Władysław Smoleński, Piotr Chmielowski, Ignacy Chrzanowski, Adam Mahrburg i Jan Władysław Dawid - wybitni przedstawiciele różnych dziedzin nauk społecznych ${ }^{8}$. Pod ich wpływem, w ostatnich latach gimnazjalnych, pasją Władysława stały się nauki społeczno-ekonomiczne.

W mieszkaniu Grabskich spotykali się też młodzi socjaliści. Władysław, będąc w VII i VIII klasie, prowadził aktywną działalność spiskową i agitacyjną. W przebraniu wyprawiał się do dzielnic robotniczych. „Socjaliści budzili zainteresowanie Grabskiego nie tylko czynną walką o rozwiązanie kwestii robotniczej, ale przede wszystkim możliwościami zaangażowania nauki na rzecz budowania sprawiedliwości społecznej. Na kwestię robotniczą Grabski zdawał się jednak patrzeć w kategoriach patriotycznych i państwowotwórczych, a nie wyłącznie klasowych i ideologicznych" - ocenia Kazimierz Korab9. Świadczy o tym m.in. jego uczestnictwo w wykładach Latającego Uniwersytetu i czynny udział $\mathrm{w}$ manifestacji zorganizowanej $\mathrm{z}$ okazji setnej rocznicy uchwalenia Konstytucji 3 Maja przez Ligę Polską (endecja) i podporządkowany jej Związek Młodzieży Polskiej „Zet”.

Po zdaniu matury W. Grabski zerwał z socjalizmem, natomiast jego brat Stanisław został aktywnym działaczem socjalistycznym. W listopadzie $1892 \mathrm{r}$. brał udział w paryskim spotkaniu, podczas którego powołano Zagraniczny Związek Socjalistów Polskich. Fascynacja Władysława ideologią socjalistyczną zakończyła się zatem dość szybko. Jak pisze J. Wojnarowski: „Już pod koniec swego pobytu w szkole zraził się do socjalizmu, dostrzegając sprzeczność między postępowaniem socjalistów a wyznawanymi przez nich poglądami. Władysław był bodajże pierwszym z grona swego rodzeństwa, który socjalistyczną teorię walki klasowej zastąpił koncepcjami solidaryzmu społecznego i narodowego, co nastąpiło zresztą nie bez wpływu myśli Abramowskiego" 10 .

W latach 1892-1894 W. Grabski studiował w Szkole Nauk Politycznych w Paryżu. Należy zwrócić uwagę, że nie studiował zagadnień ściśle politycznych, ale zgłębiał wiedzę w dziedzinie finansów, ekonomii politycznej i historii. Jego wykładowcami byli m.in. Albert Sorel i Leon Say. Szkołę Nauk Politycznych

\footnotetext{
${ }^{8}$ M. M. Drozdowski, op.cit., s. 17-18.

${ }^{9}$ K. Korab, op.cit., s. 18.

${ }^{10}$ Ibidem.
} 
ukończył z wyróżnieniem. W latach 1893-1895, a więc przez pewien okres równolegle, studiował historię i archiwistykę na Sorbonie. Uczęszczał m.in. na wykłady E. Lavisse'a, P. Leroy-Beaulieu (ekonomista) i Charles'a Seignobsa. Grabskiego interesowała w szczególności historia filozofii Seignobsa, zwłaszcza jej aspekt społeczny i gospodarczy (,zdrowy krytyczny sens”) ${ }^{11}$. W tym czasie problematyka agrarna stała się głównym kierunkiem jego badań naukowych. Już w czasie studiów (w 1894 r.) opublikował na łamach „Ekonomisty Polskiego” (z. XII) artykuł pt. Kwestia agrarna we Francji. Po rocznych studiach (1896-1897) w zakresie agronomii w Halle ogłosił dwa studia dotyczące zagadnień agrarnych w Niemczech ${ }^{12}$.

Dzięki studiom zagranicznym Grabski posiadł wszechstronną wiedzę w zakresie nauk humanistycznych, ekonomii, prawa i rolnictwa. Zapoznał się z nowoczesnymi metodami badań naukowych. Jak trafnie zauważa Marian M. Drozdowski, „Grabski przez znajomość kultury francuskiej, włoskiej, niemieckiej, czeskiej i rosyjskiej był Polakiem i wielkim Europejczykiem"13. Władał biegle językiem francuskim, niemieckim i rosyjskim. Języka angielskiego uczył się przez całe życie ${ }^{14}$. Praca badawcza najbardziej odpowiadała jego zainteresowaniom i charakterowi. Posiadał odpowiednie wykształcenie i zdolność do mrówczej, wręcz benedyktyńskiej pracy.

Śmierć ojca w 1897 r. spowodowała jednak, że przerwał studia w Halle i powrócił do Borowa, aby przejąć prowadzenie majątku rodzinnego (520 ha). Jednocześnie został dzierżawcą majątku w Gosławicach.

Kontynuując dzieło ojca, W. Grabski przekształcił folwark borowski w nowoczesne gospodarstwo. Zmeliorował łąki, założył duże stawy hodowlane, wprowadził specjalizację upraw ${ }^{15}$. Wybudował nowy dwór i zadbał o jego otoczenie (założył nowy park). Wzorem swego ojca kontynuował parcelację ziemi folwarcznej, umożliwiając chłopom kupno gruntów za pośrednictwem Banku Włościańskiego. Na obszarze jego majątku powstały nowe włościańskie kolonie: Feliksów, Władysławowo i Józefów ${ }^{16}$.

W. Grabski podjął równocześnie szeroko zakrojoną działalność publiczną na obszarze Królestwa Polskiego, głównie w powiecie łowickim. W okresie

${ }^{11}$ Ibidem, s. 19-20.

${ }^{12}$ W. Grabski, Wiedza a praktyka rolnicza w Niemczech, „Ateneum” 1897, T. III, z. 3; idem, Praca społeczna na wsi w Niemczech, „Ateneum” 1893, T. I, z. 3.

${ }^{13}$ M. M. Drozdowski, op.cit., s. 14.

${ }^{14}$ K. Korab, op.cit., s. 16.

${ }^{15}$ Stawy rybne miały obszar 80 ha i dawały 5 ton karpia rocznie. Borów specjalizował się w produkcji buraków cukrowych i zbóż selekcjonowanych (M. M. Drozdowski, op.cit., s. 23).

${ }^{16}$ Ibidem . 
1899-1904 założył stację doświadczalną oraz spółdzielnię rolniczą pod Kutnem, kółko rolnicze i pierwszą w kraju spółdzielnię mleczarską w Bocheniu. Organizował również w Łowickiem kasy spółdzielcze dla włościan i wspierał finansowo szkoły rolnicze w Pszczelinie i Mieczysławowie. Dużym osiągnięciem Grabskiego było utworzenie w 1904 r. w Warszawie Towarzystwa Melioracyjnego, którym początkowo kierował. W tym samym roku powołał Łowickie Towarzystwo Rolnicze ${ }^{17}$. Jego wzorem w tej działalności był ks. Piotr Wawrzyniak, wybitny organizator spółdzielczości w zaborze pruskim.

Po powrocie z Paryża Władysław zakochał się z wzajemnością w Katarzynie z Lewandowskich, córce szewca z Piątku Łęczyckiego, która pracowała jako pokojówka i lektorka jego matki. Po dwóch latach nieformalnego związku, w 1902 r. W. Grabski poślubił Katarzynę, mimo groźby wydziedziczenia i klątw matki ${ }^{18}$. Małżeństwo Władysława $z$ Katarzyną było udane i pełne harmonii. Katarzyna urodziła czterech synów: Wacława, Władysława Jana, Zdzisława i Andrzeja ${ }^{19}$.

Rodzina stanowiła dla niego wielką wartość. Kochał swoją żonę. Tuż przed śmiercią wyznał: „nie dla twej krasy, nie dla twej urody, nie dla twego wdzięku, ale dla twej duszy, którą przejrzałem i pokochałem, wziąłem cię"20. Synom zapewnił staranne wykształcenie. $Z$ rodzeństwem utrzymywał bliskie i serdeczne kontakty. Świadczy o tym bogata korespondencja. Najczęściej korespondował ze Stanisławem. Wymieniał z nim poglądy dotyczące polityki i pracy naukowej. Mimo dzielących ich różnic politycznych byli sobie bardzo bliscy. Niepokoili się zwłaszcza wzajemnie swym stanem zdrowia. Rodzinę Grabskich trawiły liczne choroby $^{21}$.

${ }^{17}$ Archiwum Akt Nowych (dalej AAN), Akta Władysława Grabskiego, sygn. III-9, j. 7.

${ }^{18}$ W. J. Grabski, op.cit., s. 32.

${ }^{19}$ Wacław zmarł w wieku 16 lat (gruźlica), Władysław Jan - dr praw, znany publicysta i pisarz historyczny; Zdzisław - absolwent Wyższej Szkoły Handlowej we Fryburgu, profesor Politechniki Gdańskiej; Andrzej - absolwent Szkoły Głównej Gospodarstwa Wiejskiego, po II wojnie światowej wykładał socjologię wsi na Uniwersytecie Łódzkim (AAN), Akta Władysława Grabskiego, sygn. III-9, j. 1).

${ }^{20}$ Cyt. za: K. Korab, op.cit., s. 22.

${ }^{21}$ Władysław pisał do brata: „Kochany Stasiu. Cieszę się, że jak piszesz idzie u Ciebie ku lepszemu i że obejdzie się bez zabiegu chirurgicznego [miał kłopot z jelitami]. U Władka [Władysława Jana] też znacznie się poprawiło. Będziemy u niego w święta. Już nie ma wcale prądków gruźliczych... proces trwa tylko już inny. Małe komplikacje w grubej kiszce nie budzą obaw lekarzy. Ale utrudniają trawienie i daje się to Władkowi we znaki. Wygląd ma dobry i zdrowy, więc jest nadzieja, że wyzdrowieje zupełnie. Tylko kuracja będzie długa, bo ma trwać 4 lata z przerwami... Piszesz, żeby Kasia [żona Władysława] zaprzestała palić papierosy. Otóż od 
Władysław Grabski, będąc już ciężko chory, zachowywał spokój i wyjątkowe opanowanie ${ }^{22}$.

W lutym 1905 r. Grabski został aresztowany i osadzony na Pawiaku. Do więzienia carskiego trafił za aktywny udział w kampanii chłopskiej na rzecz samorządu gminnego i polonizacji wszystkich instytucji publicznych w Królestwie Polskim. Podpisał się też pod petycją, którą przygotował w tej sprawie H. Sienkiewicz. Dzięki staraniom żony wyszedł na wolność. Katarzyna złożyła świadectwo lekarskie (fałszywe, za łapówkę) o ciężkiej chorobie męża, grożącej utratą słuchu. Był współorganizatorem pochodu narodowego w Warszawie 5.11.1905 r. ${ }^{23}$

W tym czasie Grabski zbliżył się do Stronnictwa Narodowo-Demokratycznego (SN-D). Działacze Stronnictwa występowali przeciw ugodowcom i serwilizmowi prorosyjskiemu oraz socjalistom i ich koncepcji walki klas, która godziła w jedność narodową i tradycyjne wartości społeczeństwa polskiego. W $1906 \mathrm{r}$. z ramienia SN-D wszedł do Dumy (parlamentu rosyjskiego). Koło Polskie liczyło kilkudziesięciu posłów. W. Grabski, będąc w latach 1906-1912 przedstawicielem endecji w Dumie, bronił z powodzeniem interesów polskich ${ }^{24}$.

W sprawach politycznych aprobował program endecji. Był za zjednoczeniem ziem polskich i wzmacnianiem ducha narodowego. Wypowiadał się przeciwko postawie służebnej wobec Rosji. Odpowiadał mu pogląd narodowych demokratów, że lud powinien być „fundamentem narodu, głównym i ostatecznym źródłem jego siły i trwałości”. W poglądach społecznych Grabski zachował jednak samodzielność. Był za ograniczeniem stanu posiadania wielkiej własności, bronił warstwy chłopskiej. Przypisywał szczególną rolę demokracji w życiu publicznym. Negatywnie oceniał „egoizm narodowy” (nacjonalizm), podsycany przez niektórych działaczy SN-D.

W 1907 r. wydał własnym nakładem dokumenty poselskie. Na posiedzeniu Komisji Budżetowej II Dumy przedstawił wniosek dotyczący reformy podatków gruntowych w Królestwie Polskim. Domagał się jednego podatku gruntowego

pół roku nie bierze wcale papierosa do ust. Było już z nią źle latam (ciśnienie 220), ale teraz jest lepiej (192)" (AAN, Akta Władysława Grabskiego, sygn. III-9, j. 1, k. 21. List do Stanisława z 30.12.1929 r.).

${ }^{22}$ Pisał do Stanisława: „Twój list jest smutny, co się rzadko u Ciebie zdarza... Ale to nie znaczy, jeżeli człowiekowi dolega wiek, że ma rezygnować z robienia czegoś. Najlepiej zawsze być nastawionym na robienie czegoś. Niech klamka zapadnie w pełni ruchu. Trudno uznać, kiedy przyjdzie koniec. Nie trzeba o nim myśleć specjalnie, ani się do niego sposobić" (ibidem, k. 38. List do Stanisława, lata trzydzieste, brak dokładnej daty).

${ }^{23}$ M. M. Drozdowski, op.cit., s. 31-33.

${ }^{24}$ Ibidem, s. 36-45. 
i znacznego zmniejszenia podatków płaconych przez polskich rolników. W lutym 1908 r. Grabski przedstawił memoriał zawierający główne założenia programowe dla polskiej delegacji poselskiej w III Dumie. Zwracał się w nim do władz carskich o zniesienie $5 \mathrm{mln}$ rb podatków gruntowych i $2 \mathrm{mln}$ rb podatków miejskich płaconych przez mieszkańców Królestwa na rzecz skarbu rosyjskiego. Żądał ponadto respektowania prawa do posługiwania się językiem polskim w samorządach i szkolnictwie. Dzięki jego zabiegom, przy wsparciu posłów Koła Polskiego, Duma uchwaliła kredyty na finansowanie działalności polskich stowarzyszeń i kółek rolniczych. W 1908 r. starał się wpłynąć na polskich posłów w III Dumie, aby wzmogli wysiłki, mające na celu poprawę położenia „naszego narodu" w państwie rosyjskim ${ }^{25}$. Grabski uznał za podstawowe zadanie Polaków, aby podjęli działania mające na celu wykazanie wyższości ekonomicznej nad gospodarką rosyjską; obronili swą tożsamość narodową i przygotowali grunt do autonomii. Można zauważyć, że chciał pójść podobną drogą, jaką obrał ks. Ksawery Drucki-Lubecki.

W. Grabski, przebywając w Petersburgu, kontynuował pracę naukową i publicystyczną dotyczącą głównie rolnictwa w Królestwie Polskim. W swych studiach statystyczno-ekonomicznych udowadniał niezbicie, że rosyjski aparat fiskalny dokonuje $\mathrm{w}$ majestacie prawa systematycznego wyzysku ziem Królestwa Polskiego. Według jego obliczeń, udział Królestwa w wydatkach skarbu państwa na potrzeby rolnictwa w Rosji europejskiej wynosił zaledwie $0,7 \%$, natomiast kwota podatków gruntowych płaconych przez Królestwo stanowiła 40,4\% ściąganych należności. W 1912 r., wobec niemożności uzyskania w parlamencie rosyjskim jakichkolwiek korzyści dla sprawy polskiej, zrezygnował z kandydowania do IV Dumy ${ }^{26}$.

W latach 1913-1914 W. Grabski pracował w Centralnym Towarzystwie Rolniczym. Zorganizował w nim Biuro Pracy Społecznej. Został jego dyrektorem i kierownikiem sekcji ekonomiczno-społecznej. Prowadził wówczas badania dotyczące najważniejszych potrzeb ekonomicznych i społecznych kraju. Brał udział w zbieraniu materiałów do „Roczników Statystycznych Królestwa Polskiego"27.

W okresie I wojny światowej W. Grabski aktywizuje w ramach orientacji prorosyjskiej swą działalność na rzecz sprawy polskiej. Po wybuchu wojny

${ }^{25}$ Ibidem, s. 39-40.

${ }^{26}$ Biorąc pod uwagę ówczesne warunki, efekty działalności Grabskiego były wcale niemałe. Wniósł duży wkład w rozwój szkolnictwa elementarnego i średniego. Dzięki jego wysiłkom zarejestrowano w Królestwie Polskim wiele towarzystw naukowych, kulturalnych i zawodowych. Od 1912 r. współpracował z Towarzystwem Naukowym Warszawskim (ibidem, s. 44).

${ }^{27}$ AAN, Akta Władysława Grabskiego, sygn. III-9, k. 3. 
(8.08.1914 r.) Wiktor Jaroński, działacz Stronnictwa Demokratyczno-Narodowego, w imieniu Koła Polskiego w IV Dumie, wystąpił ze znamienną deklaracją, z którą solidaryzował się W. Grabski. Stwierdzono w niej: „Niech za pomocą Bożą Słowiaństwo pod egidą Rosji odeprze Teutonów, podobnie jak pięć wieków temu uczyniły to pod Grunwaldem Polska i Litwa. Oby krew przez nas wylana oraz okropności tej bratobójczej dla nas wojny doprowadziły do zjednoczenia rozerwanego na trzy części narodu polskiego" ${ }^{28}$. Stanowisko to potwierdzili narodowi demokraci i tzw. realiści z zaboru rosyjskiego w deklaracji z 16.08.1914 r. ${ }^{29}$

Dnia 8 sierpnia 1914 r., z inicjatywy Grabskiego, powołano Centralny Komitet Obywatelski (CKO), który niósł pomoc setkom tysięcy mieszkańców najbardziej poszkodowanych przez wojnę. CKO przyjął z nadzieją odezwę wielkiego księcia Mikołaja Mikołajewicza do Polaków z 14.08.1914 r., w której obiecywał połączenie ziem polskich pod berłem cara. Zapowiadał wolność języka polskiego i religii oraz samorzą ${ }^{30}$. Grabski wszedł również w skład Komitetu Narodowego Polskiego (powołali go działacze endecji 25.11.1914 r.). Komitet występował przeciwko Naczelnemu Komitetowi Narodowemu, który był związany z orientacją austriacką ${ }^{31}$.

Po wkroczeniu wojsk niemieckich do Warszawy (5.08.1915 r.) Grabski wyjechał w głąb Rosji, organizując pomoc dla tysięcy polskich uchodźców. W latach 1916-1917 pod opieką Centralnego Komitetu Obywatelskiego i innych polskich organizacji charytatywnych znalazło się ponad 800 tys. osób spośród ludności cywilnej. Organizowano dla nich szpitale, schroniska, sklepy oraz szkoły. Ogółem utworzono kilka tysięcy polskich szkół ${ }^{32}$.

W. Grabski poświęcił się całkowicie działalności CKO. Praca ponad siły odbiła się na jego zdrowiu. Nie zrezygnował jednak z prowadzenia tak ważnej dla Polaków misji. Przyczynił się do wielkiego dzieła, jakim było uchronienie od śmierci tysięcy ludzi rozproszonych po olbrzymich obszarach Rosji i Syberii. Jednocześnie dokumentował skutki wojny i przygotowywał program odbudowy państwa polskiego ${ }^{33}$.

${ }^{28}$ Cyt. za: M. M. Drozdowski, op.cit., s. 54.

${ }^{29} \mathrm{~W}$ deklaracji stwierdzono, że tylko „Zwycięstwo koalicji rosyjsko-francusko-angielskiej daje narodowi polskiemu widoki zjednoczenia wszystkich ziem polskich z dostępem do Bałtyku..." (J. Buszko, Historia Polski, 1864-1948, Warszawa 1978, s. 226-227).

${ }^{30}$ Zarys historii Polski, red. J. Tazbir, Warszawa 1980, s. 573.

${ }^{31}$ Ibidem.

${ }^{32}$ K. Korab, op.cit., s. 25.

33 „Rocznik Statystyczny Królestwa Polskiego”. Dopełnienie do roku 1914, oprac. pod kierunkiem W. Grabskiego, Piotrogród 1915; W. Grabski, Podstawy sity wewnętrznej państwa polskiego. Materiały i studia w sprawie odbudowy Państwa Polskiego, Piotrogród 1917. 
Szykany ze strony władz bolszewickich zmusiły Grabskiego do powrotu do kraju. W kwietniu 1918 r. został aresztowany przez policję niemiecką i osadzony w twierdzy Modlin. Podczas półrocznego pobytu w więzieniu pracował naukowo, przygotowując studia dotyczące polityki agrarnej w Polsce ${ }^{34}$.

W październiku 1918 r. Grabski został ministrem rolnictwa w rządzie Józefa Świeżyńskiego podległym Radzie Regencyjnej. Prace dotyczące przygotowania reformy rolnej przerwała mu rychła dymisja rządu (3.11.1918 r. $)^{35}$.

Powołanie gabinetu Ignacego Paderewskiego w 1919 r. otworzyło nowy rozdział w działalności publicznej W. Grabskiego. Dnia 31.01.1919 r. Naczelnik Państwa, Józef Piłsudski, powołał Grabskiego na dyrektora Głównego Urzędu Likwidacyjnego. Celem Urzędu było ustalenie strat wojennych oraz przygotowanie i prowadzenie wszelkich spraw związanych z rozrachunkiem z państwami zaborczymi. Decyzją Naczelnika Państwa z 1.04.1919 r. został mianowany trzecim delegatem do spraw ekonomicznych i finansowych RP (po Romanie Dmowskim i Ignacym Paderewskim) na konferencję pokojową. Dzięki jego wiedzy i zdolnościom negocjacyjnym udało się uchronić kraj przed poważniejszymi obciążeniami finansowymi z tytułu dawnego zadłużenia państw zaborczych $^{36}$. W liście z 6.04.1919 r. wzywał Paderewskiego, aby za pośrednictwem państw Ententy przeciwstawił się eksploatacji Polski przez Austrię ${ }^{37}$.

W styczniu 1919 r. W. Grabski został posłem do Sejmu Ustawodawczego z listy Związku Ludowo-Narodowego (endecji) na kadencję 1919-1922. Od 13.12.1919 r. do czerwca 1920 r. pełnił funkcję ministra skarbu w rządzie Leona Skulskiego. W tym czasie zunifikował walutę, upowszechniając markę polską, która w kwietniu 1920 r. stała się jedynym oficjalnym środkiem płatniczym. Przystąpił do realizacji programu naprawy finansów państwa, zahamowania inflacji i przeprowadzenia reformy walutowej. Opracował też projekt utworzenia Banku Emisyjnego. Jego realizację miał zapewnić dopływ walut z pożyczki amerykańskiej oraz z eksportu drewna. W tym celu przy Ministerstwie Skarbu

${ }^{34}$ Były to następujące opracowania: W. Grabski, Cele i zadania polityki agrarnej $w$ Polsce, Warszawa 1918; Materiały w sprawie włościańskiej, Warszawa 1919; Społeczne gospodarstwo agrarne w Polsce, Warszawa 1923.

${ }^{35}$ AAN, Akta Władysława Grabskiego, sygn. III-9, k. 5.

${ }^{36}$ Polska przyjęła dług wynikły z likwidacji jej stosunków z mocarstwami rozbiorowymi w wysokości 1,3 mld marek i 190 mln koron w złocie oraz 1,4 mld koron w papierach wartościowych. Po potrąceniu strat wojennych Polsce pozostał dług w kwocie przeszło $35 \mathrm{mln}$ dol. (M. M. Drozdowski, op.cit., s. 87; J. Skodlarski, Zarys historii gospodarczej Polski, WarszawaŁódź 2000, s. 242).

37 W. Grabski, Dwa lata pracy u podstaw państwowości naszej (1924-1925), oprac. M. M. Drozdowski, Warszawa-Rzeszów 2003, s. 19. 
utworzony został samodzielny komitet eksportu drewna. Plany te zniweczyła wojna polsko-bolszewicka ${ }^{38}$.

Dnia 23.06.1920 r., w obliczu narastającego zagrożenia bolszewickiego i trudnej sytuacji gospodarczej kraju, W. Grabski objął funkcję prezesa Rady Ministrów. Pełnił jednocześnie obowiązki ministra skarbu.

W. Grabski w swym pierwszym exposè (30 czerwca) stwierdził, że „decyzje w sprawach, w których o byt narodu chodzi, muszą być tak samo szybkie, jak decyzja żołnierza na polu bitwy". W związku z tym zaproponował powołanie Rady Obrony Państwa. Ustawę w tej sprawie Sejm uchwalił nazajutrz ${ }^{39}$. Radę wyposażono w bardzo dużą władzę. Wszystkie jej rozporządzenia i zarządzenia podlegały natychmiastowemu wykonaniu. Podstawowym zadaniem rządu było wyposażenie i aprowizacja armii oraz zaopatrzenie ludności miejskiej w żywność ${ }^{40}$.

Koszty związane z finansowaniem wojny rosły wówczas lawinowo. Bez pomocy Ententy Polska nie była w stanie dalej prowadzić wojny. W. Grabski, licząc na pożyczki zagraniczne, w przeciwieństwie do swoich poprzedników, widział konieczność równoczesnej aktywizacji wewnętrznych źródeł dochodów. Proponował m.in. finansowanie wydatków nadzwyczajnych z nowych podatków (podatku od spadków, podatku dochodowego) oraz uruchomienia pożyczek wewnętrznych ${ }^{41}$.

Wydatki na potrzeby Ministerstwa Spraw Wojskowych i Ministerstwa Aprowizacji wyniosły łącznie - w okresie 1.07.1919-31.03.1920 - 30 mld marek polskich, tj. dwukrotnie więcej niż preliminowane rozchody budżetowe. Dochody ze źródeł wewnętrznych, mimo wprowadzenia nowych podatków i opłat, niweczyła postępująca inflacja. Przewidywane kredyty zagraniczne na zaopatrzenie armii nie napłynęły. W tych warunkach plan Grabskiego dotyczący stabilizacji waluty, jej reformy i przywrócenia równowagi budżetowej musiał się załamać $^{42}$.

${ }^{38}$ AAN, Akta Władysława Grabskiego, sygn. III-9; W. Grabski, Dwa lata pracy u podstaw państwowości naszej (1924-1925), Lublin 2004, s. 11.

${ }^{39}$ W. Pobóg-Malinowski, Najnowsza historia polityczna Polski, 1864-1945, t. 2, cz. 1, Londyn 1956, s. 270.

${ }^{40}$ A. Podolska-Meducka, $\mathrm{O} d$ wojny do wojny. System świadczeń wojennych w Polsce w latach 1918-1921, Warszawa 2011.

${ }^{41}$ Z. Landau, J. Tomaszewski, Gospodarka Polski międzywojennej 1918-1939, t. I, W dobie inflacji 1918-1923, Warszawa 1967, s. 262.

${ }^{42}$ W. Grabski, Dwa lata pracy u podstaw państwowości naszej (1924-1925), Warszawa 1927, s. 8-9 i 10-11; Z. Landau, J. Tomaszewski, op.cit., s. 264-265. 
Ze względu na potrzeby wojska odbudowano i rozbudowano transport kolejowy. W okresie 1919-1920 długość linii kolejowych wzrosła prawie dwukrotnie (z $6613 \mathrm{~km}$ do $13763 \mathrm{~km}$ ). W. Grabski, mimo braku środków finansowych, uczynił wiele, aby przygotować zaplecze ekonomiczne dla działań militarnych. Słusznie Marian M. Drozdowski zauważa, że „Zasługi Grabskiego w organizowaniu obrony kraju przed agresją bolszewicką bardzo słabo eksponuje polska historiografia"43. Jego zasługą było też przyjęcie przez Sejm 18.07.1920 r. ustawy o reformie rolnej (zob. rozdz. IV, pkt. 3).

W lipcu 1920 r. na konferencji w Spa w zamian za obiecaną pomoc państw zachodnich i zawarcie rozejmu w wojnie $\mathrm{z}$ Rosją Radziecką, zaaprobował niekorzystne dla Polski postanowienia, m.in. w sprawie Zaolzia i Gdańska, co wywołało w kraju falę krytyki. Był to główny powód ustąpienia (24.07.1920 r.) Grabskiego ze stanowiska premiera ${ }^{44}$.

Podjęcie tej decyzji burzyło Grabskiemu przez wiele lat spokój wewnętrzny. W 1926 r. wspominał: „Spa było dla mnie w ciągu szeregu lat źródłem dużej moralnej udręki. Wciąż nasuwało się mi pytanie - czy nie należało zerwać rozmowy z aliantami z punktu, przedstawić narodowi całą prawdę, zażądać ofiar jak największych dla walki, nie oglądając się na sojuszników, którzy w momencie decydującym Polskę opuścili. Tak powinienem postąpić, gdybym wierzył w siły ofiarne i tężyznę naszego narodu. Tej wiary mi brakowało" ${ }^{45}$.

W. Grabski pełnił nadal funkcję ministra skarbu w rządzie Wincentego Witosa. W sierpniu 1920 r., jako minister skarbu, podpisał odezwę rządu do rodaków, w której odsłaniał prawdziwe oblicze bolszewizmu. Stwierdzał w niej, że Armia Czerwona chce obrabować i złupić Polskę, uczynić z niej pustynię, podobną do Rosji sowieckiej ${ }^{46}$. Grabski, jak mało kto, znał zamiary i metody władzy bolszewickiej. W tym okresie koncentrował swe wysiłki (wraz z gen. Kazimierzem Sosnkowskim) na przygotowaniu środków umożliwiających realizację śmiałej operacji militarnej, tj. ofensywy armii polskiej znad Wisły i Wieprza.

W listopadzie 1920 r., kiedy minęło zagrożenie wojenne, opracował przy pomocy swoich współpracowników, „Projekt programu polityki ekonomicznej i finansowej Polski po wojnie" (zob. rozdz. II). Zasadniczą ideą programu było przejście od gospodarki wojennej do odbudowy i normalizacji życia społeczno-gospodarczego. Zwraca uwagę jego kompleksowość, fachowość i dalekowzroczność,

\footnotetext{
${ }^{43}$ M. M. Drozdowski, op.cit., s. 104.

${ }^{44}$ A. Garlicki, Historia, 1815-2004, Polska i świat, Warszawa 2005, s. 244-245.

${ }^{45}$ Cyt. za M. M. Drozdowski, op.cit., s. 127.

${ }^{46}$ Ibidem, s. 136.
} 
a także odwaga autorów. Trwała jeszcze wojna i żądania radykalnego zmniejszenia wydatków wojskowych i aprowizacyjnych spotkały się ze sprzeciwem sfer wojskowych i wielu polityków.

Po złożeniu dymisji w pierwszym gabinecie W. Witosa przyjął w $1921 \mathrm{r}$. funkcję Nadzwyczajnego Komisarza Rządu dla Repatriacji Polaków z Rosji. W 1922 r. został dyrektorem Polsko-Amerykańskiego Komitetu Pomocy Dzieciom. W Sejmie, jako poseł, zajął się poprawą finansów państwa i polityką rolną rządu ${ }^{47}$.

Postępująca inflacja skłoniła prezydenta Stanisława Wojciechowskiego do zwołania 2.01.1923 r. narady wszystkich byłych ministrów skarbu w celu uzgodnienia zasad dalszej polityki skarbowej i walutowej. Jej uczestnicy byli zgodni, że warunkiem skuteczności reform jest stały rząd, zaplanowanie naprawy na dłuższy okres oraz podniesienie podatków, opłat i taryf ${ }^{48}$.

Następstwem konferencji było mianowanie ministrem skarbu W. Grabskiego, tym razem w rządzie gen. Władysława Sikorskiego. Rozpoczął on przygotowania do przeprowadzenia reformy walutowej. Warunkiem jej powodzenia było osiągnięcie równowagi budżetowej. Zakładał, że osiągnie ją w przeciągu 3 lat. Pokrycie deficytu budżetowego miały zapewnić następujące źródła dochodów: podatek majątkowy (600 mln zł, pożyczka zagraniczna (500 mln zł), pożyczka wewnętrzna (110 mln zł) i inflacja (120 mln zł). Grabski planował utworzenie Polskiego Banku Emisyjnego. Opracowanie jego projektu powierzył znakomitemu fachowcowi, Romanowi Rybarskiemu ${ }^{49}$. Pogarszająca się sytuacja finansowa państwa oraz indolencja parlamentu spowodowały, że Grabski musiał zaniechać realizacji tego projektu.

${ }^{47}$ Dnia 1.07.1921 r. przedstawił projekt poselski, w którym proponował waloryzację podatków i opłat, redukcję urzędników, wypuszczenie pożyczki wewnętrznej w walucie złotej w stosunku do dolara i utworzenie Banku Emisyjnego. Na posiedzeniu Sejmu 3.03.1923 r. przedstawił program naprawy skarbu. Uzasadnił jego konieczność, cel, główne działania i skutki gospodarczo-społeczne. Grabski mówił o potrzebie podwyższenia podatku dochodowego, niektórych podatków pośrednich, zwiększenia opłacalności kolei i wprowadzenia oszczędności budżetowych. Posłowie, a następnego dnia prasa, wyrażała podziw dla wiedzy i talentu krasomówczego W. Grabskiego: „Choć mówił przeszło trzy godziny, nie miał nawet ćwiartki papieru w ręku. Raz tylko poprosił o kilkuminutową przerwę, aby mógł odpocząć... Nawet zawodowi psuje nie śmieli mu przeszkadzać... Wszyscy byli z olbrzymim respektem dla tego ogromu pracy, wiedzy i wyników przemyślanych dociekań nad środkami ratunku dla naszego skarbu. Lecz znowu stronnictwa sejmowe, tym razem bardziej prawica niż lewica udaremniła plan naprawy skarbu” („Nowiny Finansowe" 1923, nr 24).

${ }^{48}$ Z. Landau, J. Tomaszewski, op.cit., s. 270-271.

${ }^{49}$ AAN, Akta Władysława Grabskiego, sygn. III-9; L. Landau, J. Tomaszewski, op.cit., s. 271 i 286. 
W. Grabski, mimo zmiany rządu, pełnił nadal funkcję ministra skarbu. Ponownie premierem został W. Witos $(7.05 .1923$ r.). W tym czasie zaczął gwałtownie spadać kurs marki polskiej. Skutki hiperinflacji wyniszczały gospodarkę polską. Grabski w lipcu podał się do dymisji, ponieważ nie uzyskał, jako minister skarbu, poparcia premiera dla swoich projektów reformy walutowej ${ }^{50}$.

Oficjalnie oświadczył, że jego działalność nie jest dostatecznie zharmonizowana z obecnym rządem. Witos argumentował, że Grabski nie spełnił żądań gabinetu, który domagał się „najsurowszych represyj przeciwko bankom walutowym". Zwolennicy Grabskiego odpowiedzieli zgodnie, że nie kto inny, jak właśnie Grabski walczył ze spekulacją banków i doprowadził do „rozgromienia aferzystów bankowych" 51 .

Następcom Grabskiego na stanowisku ministra skarbu, Herbertowi I. Lindemu i Władysławowi Kucharskiemu, nie udało się opanować hiperinflacji i głębokiego kryzysu struktur państwowych. W Sejmie i w prasie zarzucano im brak kompetencji. Wyrażano ubolewanie, że w Polsce marnuje się ludzi zdolnych i doświadczonych (chodziło o byłego ministra Jerzego Michalskiego i W. Grabskiego) ${ }^{52}$.

Po upadku gabinetu Witosa, spowodowanym zaostrzeniem sytuacji politycznej i katastrofalną sytuacją finansową kraju, prezydent Stanisław Wojciechowski powołał 20.12.1923 r. rząd pozaparlamentarny, na którego czele stanął Władysław Grabski. Objął on także tekę ministra skarbu.

W. Grabski przystąpił niezwłocznie do przeprowadzenia reform skarbowych. Reforma walutowa doczekała się obfitej literatury. W związku z tym ograniczę się do przedstawienia jej najbardziej istotnych wątków. W swym exposè oznajmił, że traktuje naprawę Skarbu Państwa jako zadanie pierwszoplanowe. Uznał on, że w wyjątkowej sytuacji konieczne są wyjątkowe metody działania. Powodzenie programu reform zależało w dużym stopniu od szybkości i skuteczności działania. Wobec tego rząd zwrócił się do Sejmu o udzielenie mu pełnomocnictw upoważniających wydawanie rozporządzeń $\mathrm{z}$ mocą ustawy $\mathrm{w}$ sprawach związanych $\mathrm{z}$ reformami, bez uciekania się

${ }^{50}$ Ibidem.

51 „Express”, 30.06.1923.

${ }^{52}$ „W dziedzinie Skarbu bierze się i brało się Kucharskich, Jastrzębskich, Fajansów, podczas gdy dwaj do tej pory jedynie wypróbowani znawcy spraw skarbowych i tędzy włodarze Skarbu, pp. dr Jerzy Michalski i Władysław Grabski muszą przymusowo odpoczywać dlatego, że pierwszy z nich padł ofiarą niechęci ze strony p. Józefa Piłsudskiego, a drugi naraził się prawicowym adwokatom banków i wielkich fabrykantów. Słowem, marnotrawstwo na całej linii. Marnotrawimy pieniądze państwowe i narodowe, marnotrawimy czas i marnotrawimy ludzi zdolnych i doświadczonych. Cóż więc potem się dziwić, że w naszem Państwie zaczyna się dziać coraz gorzej” („Nowiny Finansowe”, 18.10.1923). 
każdorazowo do decyzji parlamentu. Sejm udzielił żądanych pełnomocnictw na okres sześciu miesięcy, a następnie przedłużył na kolejne pięć miesięcy ${ }^{53}$.

„Była to rzecz niesłychana w historii parlamentaryzmu. Sejm sprawy ratowania Rzeczypospolitej złożył w ręce jednego człowieka” - stwierdził Andrzej Wierzbicki ${ }^{54}$.

Premier Grabski uznał, że wobec braku możliwości uzyskania pożyczki zagranicznej, środki niezbędne do naprawy skarbu muszą być zgromadzone w oparciu o zasoby wewnętrzne (waloryzacja podatków i pożyczek wewnętrznych $)^{55}$. Najważniejszym instrumentem takiej polityki stał się podatek majątkowy, którym obciążono właścicieli przedsiębiorstw przemysłowych, handlowych, gospodarstw rolnych, domów itd. o wartości ponad $10000 \mathrm{fr}$ szwajcarskich. Ustawa o podatku majątkowym upoważniała rząd do pobrania 1 mld fr szwajcarskich w złocie w latach 1924-1926 ${ }^{56}$.

W. Grabski przystąpił energicznie do realizacji śmiałego planu, który polegał na podjęciu jednoczesnych działań mających na celu zrównoważenie budżetu i sanację waluty polskiej. Przedsięwzięcie to stanowiło ewenement w historii reform skarbowych ${ }^{57}$.

Inicjatywa ustawodawcza Grabskiego napotkała znaczny opór. W innym kształcie widziała reformę tzw. szkoła ekonomistów krakowskich. Byli jej przeciwni posłowie $\mathrm{z}$ klubów mniejszości narodowych oraz Chłopskie Stronnictwo Radykalne. Ostatecznie, gabinet Grabskiego poparło 194 posłów, 95 było przeciwnych.

W. Grabski apelował w exposè o poparcie społeczne reform i pokój wewnętrzny: „zaprzestanie ostrych tarć i walk wewnętrznych. Ażeby taki stan

${ }^{53}$ Z. Landau, J. Tomaszewski, Zarys historii gospodarczej Polski, 1918-1939, Warszawa 1962, s. 83.

${ }^{54}$ A. Wierzbicki, Wielka reforma, [w:] Wspomnienia i relacje o reformach Władystawa Grabskiego, wyb. i oprac. M. M. Drozdowski, Warszawa 2004, s. 153.

${ }^{55}$ W. Grabski wspominał: „eksperci angielscy mówili, że reformy walutowej przeprowadzić na razie nie można, że trzeba postępować ostrożnie. Radzili przerzucenie różnych ciężarów państwowych na samorządy [...] przede wszystkim wskazywali na to, że za dużo wydajemy na armię [...] Co do pożyczki zagranicznej zaznaczyli, że się stanie ona możliwa dopiero, gdy zagranica nabierze do nas zaufania, a to ostatnie nastąpić może dopiero wtedy, gdy będziemy dobrym radom posłuszni. Przyłączali się przy tym do poglądu, że bez pożyczki zagranicznej, jako rezerwy, do reformy walutowej przystępować nie należy..." (W. Grabski, Myśli o Rzeczypospolitej. Autonomia, reforma, edukacja obywatelska. Wybór myśli politycznych i społecznych, wyb. i wstęp M. M. Drozdowski, Kraków 1988, s. 105-106).

${ }^{56}$ W. Breit, B. Blumenfeld, Podatek majątkowy, Lwów 1924.

${ }^{57}$ AAN, Akta Władysława Grabskiego, sygn. 17. Przemówienie W. Grabskiego. 
rzeczy mógł istnieć, rząd zapowiada ze swej strony jak największą bezstronność w zakresie wszelkich zagadnień, które dzielą społeczeństwo na zwalczające się obozy" 58 .

Zahamowanie hiperinflacji umożliwiło przeprowadzenie reformy walutowej. Markę zastąpiono złotym ( $1 \mathrm{zl}=1$ fr szwajcarski w złocie), którego wartość zabezpieczały rezerwy złota i dewiz. Dla wprowadzenia w życie tej reformy utworzono w połowie kwietnia 1924 r. Bank Polski z wyłącznym prawem emisji banknotów. Jego prezesem został Stanisław Karpiński. Pierwszy etap reformy zakończył się powodzeniem ${ }^{59}$. Podkreślano, że było to osiągnięcie polskiej racji stanu i osobisty sukces Grabskiego ${ }^{60}$.

W końcu 1924 r. pojawiły się pomyślne objawy w gospodarce polskiej. Dochody skarbu wzrosły, koniunktura uległa lekkiej poprawie. Reforma walutowa przeprowadzona o własnych siłach była wielkim dziełem, które uratowało odrodzone państwo polskie od katastrofy gospodarczej i osłabienia suwerenności.

Istotny był też wkład Grabskiego w rozwój ustawodawstwa socjalnego. Rząd z jego inicjatywy przygotował ustawę rozszerzającą ubezpieczenie od wypadków na były zabór pruski, ustawę o ochronie pracy kobiet i młodocianych oraz ustawę o ubezpieczeniu robotników na wypadek bezrobocia. Te akty prawne zatwierdził Sejm w 1924 r. ${ }^{61}$ W lutym 1925 r. premier doprowadził do podpisania konkordatu ze Stolicą Apostolską.

Prezydent RP, Stanisław Wojciechowski, w uznaniu zasług Władysława Grabskiego w służbie państwowej, odznaczył go w 1924 r. orderem Orła Białego.

Niebawem jednak doszło do pogorszenia sytuacji gospodarczej kraju. Mimo wysiłków Grabskiego (oszczędne dysponowanie wydatkami budżetowymi, likwidacja 61497 etatów państwowych) nie udało się utrzymać równowagi

58 „Strażnica Polska”, 29.12.1923.

${ }^{59}$ G. Wójtowicz, A. Wójtowicz, Historia monetarna Polski, Warszawa 2003, s. 144-146.

${ }^{60}$ W. Grabski mówił: „Dlatego jest to wielki czyn narodu. To nas nadzwyczajnie obowiązuje. Musimy stworzyć ten gmach tak, żeby go żadne podmuchy, żadne niebezpieczeństwo, któreby na niego czyhało, nie osłabiło, żeby przetrwał on pewien okres wahań, które w każdem państwie są niedostępne od biegu życia. A stanie się to tylko wtedy, jeśli świadomi będziemy, że w działaniach naszych nie powinniśmy się kierować tem, żeby dogodzić tym lub innym, żeby dawać na prawo lub na lewo, jak sparaliżować te lub inne nieukontentowania, ale jeśli skupimy całą naszą energię duchową do tego, żeby zabezpieczyć najlepiej ten pieniądz, który jest powierzony temu Bankowi...

Po przemówieniu premiera obecni wstają i oklaskują mówcę, wznosząc na jego cześć okrzyki. Przez kilka minut sala manifestuje na cześć premiera Grabskiego, poczem głos zabiera prezes Banku Polskiego p. St. Karpiński” („Gazeta Poranna”, 16.04.1924).

${ }^{61}$ M. M. Drozdowski, op.cit., s. 195. 
budżetowej. W połowie 1925 r. nastąpiła inflacja złotego, tzw. inflacja bilonowa (nadmiar emisji bilonu). Premier, pozbawiony zaplecza partyjnego, uległ naciskom niektórych ugrupowań i resortów w sprawie zwiększenia kredytów, z których część nie została spłacona. Wśród innych przyczyn inflacji należy wymienić wojnę celną $\mathrm{z}$ Niemcami, deficyt $\mathrm{w}$ handlu zagranicznym (spadek eksportu) oraz trudności w ściąganiu podatków. W. Grabski, obawiając się powrotu spirali inflacyjnej, przedłożył 30 września 1925 r. Radzie Ministrów nowy program walki o utrwalenie stabilizacji złotego. Przewidziano w nim m.in., że podstawą programu będzie utrzymanie pełnowartościowej waluty statutowo niezależnej od rządu. Premier proponował też utworzenie funduszu w wysokości $100 \mathrm{mln}$ zł, z którego środków można byłoby ratować banki przed bankructwem oraz zasilać kredytami przedsiębiorstwa. Wzrost pieniądza $\mathrm{w}$ obiegu powinien jedynie następować $\mathrm{w}$ wyniku poprawy bilansu handlowego oraz uzyskania pożyczek zagranicznych ${ }^{62}$.

Pomoc zagraniczna nie napływała, kurs złotego spadał, rozpoczęło się nerwowe wycofywanie bankowych wkładów pieniężnych. Banki ograniczyły kredyty, co przyczyniło się do zahamowania produkcji. W rezultacie szybko rosło bezrobocie. Niepokoje społeczne przerodziły się w nastroje antyrządowe. Opinia publiczna obróciła się przeciwko premierowi Grabskiemu ${ }^{63}$. W tej trudnej sytuacji Bank Polski odmówił interwencji na rzecz utrzymania kursu złotego. Dnia 13 listopada 1925 r. za dolara płacono już 6,50 złotego. Grabski tego dnia, zmęczony krańcowo fizycznie i psychicznie, podał się do dymisji. Inflację tę udało się zahamować w 1926 r. i kurs złotego ustabilizował się na poziomie o około $40 \%$ niższym od parytetu ustalonego w 1924 r. ${ }^{64}$

Po chwilowym załamaniu gospodarka wróciła do równowagi, ale W. Grabski zapłacił za te perturbacje wysoką cenę. Po jego dymisji rozpoczęła się kampania krytyki i oszczerstw. Krytycznie ocenili gabinet Grabskiego marszałek Piłsudski i W. Witos. W opozycji był też PSL „Piast”, co szczególnie bolało Grabskiego, gdyż to właśnie on opracował korzystną dla tego stronnictwa ustawę o reformie rolnej z $1925 r$ r. ${ }^{65}$ Najbardziej brutalnie atakowała premiera Frakcja Komunistyczna w Sejmie i partie ukraińskie ${ }^{66}$.

W. Grabski był tak rozżalony, że w maju 1926 r. odmówił prezydentowi Stanisławowi Wojciechowskiemu misji utworzenia rządu pozaparlamentarnego.

${ }^{62}$ Z. Landau, J. Tomaszewski, op.cit., s. 196-197.

${ }^{63}$ W. Pobóg-Malinowski, op.cit., s. 466-467.

${ }^{64}$ J. Skodlarski, op.cit., s. 249.

${ }^{65}$ K. Korab, op.cit., s. 53-56.

${ }^{66}$ Krytycznie ocenił politykę ekonomiczną W. Grabskiego Adam Krzyżanowski (Wspomnienia i relacje o reformach...), s. 91-97. 
Wcześniej, kiedy składał dymisję na ręce prezydenta, wziął całą winę za niepowodzenie misji na siebie: „Staję przed Panem Prezydentem Rzeczypospolitej Polskiej $\mathrm{z}$ poczuciem niespełnionego $\mathrm{z}$ mojej winy do końca obowiązku. Przed dwoma laty wezwałeś mnie Panie Prezesie do rządzenia Polską tak, by w ciągu trzech lat mogło w niej być dobrze. Stało się inaczej, odchodzimy wcześniej niż termin przez Ciebie wyznaczony i nie doprowadziliśmy do tego by było dobrze. Jest to wyłącznie moja wina. Moi ministrowie starali się jak mogli wypełniać swoje obowiązki" ${ }^{67}$.

Po wycofaniu się z życia politycznego nie zaprzestał żywo reagować na wydarzenia polityczne i gospodarcze w kraju ${ }^{68}$. Wiosną 1926 r. ogłosił kilka artykułów na łamach „Kuriera Warszawskiego”, którego redakcja wspierała opcję chrześcijańsko-demokratyczną. W jednym z nich przyznał, że jako premier popełnił błędy m.in. dlatego, że przecenił gotowość społeczeństwa polskiego do ofiar na rzecz reform państwowych ${ }^{69}$. Po zamachu majowym (1926 r.) krytycznie ocenił złamanie demokratycznych procedur przy dojściu piłsudczyków do władzy. Zarzucił także brak moralności uczestnikom życia gospodarczego ${ }^{70}$.

W. Grabski, osamotniony w życiu politycznym, nie zrezygnował z wypowiadania śmiałych poglądów. Miał odwagę krytykować postawy społeczeństwa polskiego (wszystkie warstwy), a także polityków polskich i zagranicznych. Wytknął w 1926 r. rządom państw zachodnich, że traktują ulgowo pokonane Niemcy (plan Dawesa), a Polsce, znajdującej się w trudnej sytuacji, nie spieszą z pomocą ${ }^{71}$. W artykule Eksperci zagraniczni ustosunkował się krytycznie do raportu Hiltona Younga i Edwina Kemmerera, którego realizacja utrwalałaby dotychczasową strukturę gospodarki polskiej ${ }^{72}$. Wystąpił też zdecydowanie przeciwko dewaluacji złotego (zob. rozdz. II, pkt 6). Andrzej Wierzbicki, dyrektor generalny Centralnego Związku Przemysłu Polskiego, podaje zarzuty, jakie znalazły się w sprawozdaniu H. Younga, a mianowicie: jednostronność reformatorstwa W. Grabskiego, błędne założenia polityki celnej oraz nietykalność tzw. zdobyczy socjalnych ${ }^{73}$.

${ }^{67}$ AAN, Brulion pracy Dwa lata pracy u podstaw państwowości naszej (1924-1925), sygn. III-9, j. 2, k. 232.

${ }^{68}$ AAN, Akta Władysława Grabskiego, sygn. 16. Notatki W. G. „Rzut oka na wypadki w Polsce w latach 1926-1929”, sygn. 16.

69 „Kurier Warszawski”, 8.05.1926.

70 „Drogi Naprawy” 1926, nr 5.

71 „Kurier Warszawski”, 2.05.1926.

72 „Kurier Warszawski”, 20.05.1926.

${ }^{73}$ Biblioteka Narodowa, dział rękopisów, sygn. 9751/I-V. Andrzej Wierzbicki, Wspomnienia i dokumenty (1921-1926). 
W 1927 r., kiedy rozważano możliwość uzyskania pożyczki amerykańskiej kosztem ustanowienia zagranicznej kontroli w Banku Polskim, W. Grabski rozpoczął kampanię przeciwko takim zamierzeniom. Zakończyła się ona częściowym powodzeniem. W planie stabilizacyjnym nie uwzględniono wszystkich zaleceń misji ekspertów pod przewodnictwem E. Kemmerera, m.in. propozycji wysokiej dewaluacji złotego.

Podstawowe zasady polityki walutowej W. Grabskiego zostały utrzymane. Kurs złotego ustabilizował się do końca okresu międzywojennego ${ }^{74}$.

Po wycofaniu się z życia politycznego Grabski poświęcił się pracy dydaktyczno-naukowej. Mianowany w 1923 r. profesorem Szkoły Głównej Gospodarstwa Wiejskiego, w grudniu 1925 r. powrócił do obowiązków uczelnianych. Został dwukrotnie wybrany rektorem SGGW na kadencję 1926-1927 i 1927-1928. Będąc rektorem zorganizował Zakład Polityki Ekonomicznej i pełnił funkcję kierownika. W ramach swego Zakładu utworzył w 1929 r. Sekcję Socjologii Wsi. W 1936 r. założył Instytut Socjologii Wsi i był jego dyrektorem. Z jego inicjatywy wydawano „Roczniki Socjologii Wsi” (sam je finansował). Stał się twórcą nowej dyscypliny naukowej - socjologii wsi ${ }^{75}$.

W latach 1928-1934 był prezesem Towarzystwa Ekonomicznego i Statystycznego. W 1936 r. został członkiem Rady Naukowej powołanej przez prezydenta Ignacego Mościckiego. W okresie wielkiego kryzysu ekonomicznego (1929-1933/35) prowadził badania nad jego przyczynami oraz metodami wyjścia z długotrwałej depresji, ze szczególnym uwzględnieniem sektora rolnego. Prowadził również w tym zakresie akcję odczytową.

Charakterystykę pracy naukowej W. Grabskiego bardzo trafnie przedstawił jego uczeń, Antoni Żabko-Potopowicz: „Odejście od życia politycznego pozwala Grabskiemu na oddanie się wreszcie całkowicie pracy naukowej. Pracę tę cechuje nadal dążność do służenia potrzebom życia, do szukania w niej odpowiedzi na zagadnienia, które posiadały szczególną wagę dla usunięcia bolączek nękających rzeczywistość polską. Tego rodzaju ujęcie przez Grabskiego celów swojej działalności naukowej idzie w parze z dążeniem do możliwie głębokiej analizy badanych faktów, do oparcia swych wniosków na możliwie wielkim materiale rzeczowym, do stałego pogłębiania swej wiedzy przez studiowanie ogromnej ilości najrozmaitszych dzieł z zakresu interesujących go spraw...

${ }^{74}$ Charles Dewey, doradca amerykański przy rządzie polskim wszedł na trzy lata do Rady Banku Polskiego, sprawując kontrolę nad realizacją planu stabilizacyjnego. Poczytywano to za ograniczenie suwerenności polityki gospodarczej Polski (Z. Landau, J. Tomaszewski, Zarys historii..., s. 121).

${ }^{75}$ AAN, Akta Władysława Grabskiego, sygn. III-9. 
Właśnie na tego rodzaju odczytach przejawiał się szczególnie jaskrawo talent pedagogiczny prof. Grabskiego; talent ten pozwalał mu najtrudniejsze dociekania oblekać $\mathrm{w}$ formy proste i jasne, a równocześnie tak umiejętnie łączyć teoretyczne rozważania $\mathrm{z}$ polską rzeczywistością, że stawały się one niezapomniane dla słuchaczy. Analogiczne podejście cechuje jego dzieła naukowe i powoduje, że zawarte w nich myśli wywoływały należyty oddźwięk w naszym społeczeństwie"

W. Grabskiego można śmiało nazywać „człowiekiem renesansu”. Miał rozległe zainteresowania i wrażliwą osobowość. Był melomanem, sam w chwilach napięć życiowych, szukając ukojenia, grał na fortepianie. Przeżywał wraz z rodziną sukcesy polskich sportowców. W latach trzydziestych stan jego zdrowia uległ pogorszeniu. W lutym 1937 r. przeszedł operację, po czym wyjechał na kurację do Karlsbadu. Nie dała ona oczekiwanych rezultatów. Rak w jamie brzusznej okazał się chorobą śmiertelną. Grabski w pełni świadomy zbliżającej się śmierci zamieszkał wraz z żoną w Gołąbkach pod Warszawą w tzw. Grabkowie. Jesienią 1937 r. przenieśli się do Warszawy ${ }^{77}$.

Umierał, mając świadomość całkowitego bankructwa. Wybudowane w Ołtarzewie pod Warszawą przedsiębiorstwo budowy dróg i fabryka klinkieru doprowadziło rodzinę do katastrofy finansowej ${ }^{78}$. Podpisano niewłaściwe umowy i nie uwzględniono, podejmując produkcję, polskich warunków drogowych. Przeprowadził wielką reformę, swój folwark doprowadził do rozkwitu, ale w biznesie nie sprawdził się.

Władysław Grabski, cierpiąc i będąc cały czas przytomny, zmarł $1.03 .1938 \mathrm{r}$. Został pochowany na Powązkach ${ }^{79}$.

\footnotetext{
${ }^{76}$ A. Żabko-Potopowicz, Ś.p. prof. Wtadysław Grabski, „Ekonomista” 1938, nr 1, s. 7.

${ }_{77}$ M. M. Drozdowski, op.cit., s. 275.

${ }^{78}$ Ibidem, s. 308-309.

${ }^{79}$ Ibidem, s. 310-325. Ostatnie dni życia Władysława Grabskiego.
} 



\section{Rozdzial II}

\section{Poglądy makroekonomiczne}

Władysław Grabski, dzięki studiom zagranicznym, posiadł rozległą wiedzę w zakresie ekonomii politycznej, finansów, prawa, historii, archiwistyki, socjologii i rolnictwa. Wszechstronne wykształcenie stanowiło solidną bazę do przyszłych badań naukowych i działalności publicznej. Do pracy badawczej predysponowały go szerokie horyzonty myślowe, krytycyzm i opieranie się na konkretach (źródłach), praktyka rolnicza (zarządzanie majątkami), obiektywizm (prawy charakter) i benedyktyńska wręcz pracowitość.

Pierwszy okres jego pracy twórczej zdominowała historia gospodarcza. Jego uwieńczeniem była Historia Towarzystwa Rolniczego ${ }^{1}$. Antoni Żabko-Potopowicz napisał w przedmowie do tego dzieła, że było ono w zakresie dziejów rolnictwa tym, czym Trylogia H. Sienkiewicza w polskim pisarstwie historycznym ${ }^{2}$.

Głębokie zrozumienie życia gospodarczego w przeszłości towarzyszyło nieodłącznie Grabskiemu w rozważaniach ekonomicznych. Ekonomia bowiem musi obficie czerpać z badań historycznych i zanim ,zdecydujemy się akceptować śmiałe sformułowania teoretyczne, należy je zweryfikować, zestawiając ze skrupulatnym opisem rzeczywistości danej z doświadczenia" - twierdzą autorzy klasycznego podręcznika P. A. Samuelson i W. D. Nordhaus ${ }^{3}$. W. Grabski stosował konsekwentnie tę zasadę w badaniach ekonomicznych, a w działalności gospodarczej, uwzględniając teorię, kierował się przede wszystkim realizmem. Wychodził od stwierdzeń teoretycznych i przechodził do praktyki ekonomicznej.

W. Grabski nie zajmował się, w przeciwieństwie do swego brata Stanisława, teorią ekonomii, nazywaną przez nich ekonomią społeczną. Władysław Grabski cenił teorię, ale interesował się głównie tymi wątkami, które były przydatne w realizacji jego przedsięwzięć praktycznych.

\footnotetext{
${ }^{1}$ W. Grabski, Historia Towarzystwa Rolniczego 1858-1861, t. I i II, Warszawa 1904.

${ }^{2}$ W. Grabski, Wybór pism, Warszawa 1987, s. 8.

${ }^{3}$ P. A. Samuelson, W. D. Nordhaus, Ekonomia 1, Warszawa 1995, s. 293; 26-27.
} 
Stanisław Grabski w swej bogatej twórczości naukowej wiele uwagi poświęcił teorii ekonomii. Uwieńczeniem jego badań było dzieło pt.: Ekonomia społeczna $a^{4}$. Poglądy Stanisława wywarły niewątpliwy wpływ na stosunek Władysława do nauki ekonomii ${ }^{5}$. Z drugiej strony, są podstawy, aby twierdzić, że stanowisko metodologiczne Władysława było zbieżne i korzystnie oddziaływało na podejście do konstrukcji teoretycznych Stanisława. Chodzi tu o dwie kwestie. Po pierwsze, W. Grabski, podobnie jak jego starszy brat Stanisław, uznawał badania historyczne za jedną z podstaw nauki ekonomii. Po drugie, główną metodą służącą do formułowania koncepcji i teorii ekonomicznych - uznawaną przez braci - była wnikliwa obserwacja procesów społeczno-gospodarczych (badania empiryczne) oraz gromadzenie i klasyfikacja materiału statystycznego ${ }^{6}$.

Stanisław i Władysław uważali, że zjawiska społeczno-gospodarcze, a tym samym gospodarka narodowa, nie mają charakteru abstrakcyjnego, lecz są zmienne, zależne od okoliczności, czasu i miejsca, dostosowując się nieustannie do nowych wymogów życia społecznego ${ }^{7}$. Zjawiska ekonomiczno-społeczne nie mają bowiem, ich zdaniem, charakteru prawd wiecznych i absolutnych.

Grabscy stali na gruncie społecznego charakteru nauki ekonomii oraz integralności zjawisk społecznych. Oznaczało to, że stosunki gospodarcze należy badać w połączeniu z całokształtem życia społeczno-politycznego i kulturalnego. Treścią rozważań powinna być analiza wzajemnych uwarunkowań jednostki i zbiorowości ${ }^{8}$.

${ }^{4}$ S. Grabski, Ekonomia społeczna, t. I-X, Lwów 1927-1933; zob. też: S. Duda, Przedmiot i metoda ekonomii w ujęciu Stanisława Grabskiego, [w:] Historia gospodarcza i historia myśli ekonomicznej a teoria ekonomii. Problemy metodologiczne, red. J. Skodlarski, Łódź 2008, s. 190-205.

${ }^{5}$ W liście do Stanisława napisał: „Przeczytałem Twój „Kapitał” [cz. VI]. Każdy tom jest doskonały. Dziwię się, że masz tyle umysłu do tak poważnego pisania. Mnie się nie chce poważnie pracować" (AAN, Akta Władysława Grabskiego, sygn. 2. List z 18.04.1928 r.).

${ }^{6} \mathrm{~W}$ X tomie Ekonomii społecznej napisał: „nauka ekonomii społecznej byłaby jałową konstrukcją abstrakcyjnych formul, gdyby nie wyjaśniała nam w pełni dokonywujących się dziś przemian społeczno-gospodarczych ustroju" (S. Grabski, Ekonomia społeczna, t. X, s. 3-13).

${ }^{7}$ S. Grabski, Zur Erkenntnische der Volkswirtschaflichen Erscheinungen (Przyczynek do nauki o poznaniu zjawisk gospodarczo-narodowych), Berno 1900, s. 129.

${ }^{8}$ S. Grabski uzasadniał to w sposób następujący: „W tej relacji człowiek znajduje swoje miejsce i realizuje indywidualno-gospodarczą inicjatywę. I raczej można wytłumaczyć dążenia i zabiegi gospodarcze jednostek ich kulturą, wychowaniem, majątkiem, pojęciami moralno-religijnymi niż wyprowadzić formy współżycia gospodarczego ludzi z ich sądów i działań indywidualno-gospodarczych (w izolacji i z abstrakcji)". (S. Grabski, Ekonomia społeczna ..., t. X, s. 12). 


\section{Systemy ekonomiczne}

W. Grabski, zafascynowany historią gospodarczą, dostrzegał przejawy gospodarki rynkowej już w okresie starożytności i średniowiecza. Rozwój kapitalizmu jako systemu nastąpił - jego zdaniem - jednak dopiero w połowie XIX w. Wyodrębnił trzy fazy rozwoju kapitalizmu: 1) kapitalizm wolnokonkurencyjny, 2) funkcjonujący w formie spółek - przedsiębiorstw akcyjnych (monopolistyczny), 3) „dzisiejszy, oparty na kilku jego rodzajach”9.

Charakterystyka poszczególnych faz nie odbiega zasadniczo od dzisiejszej wiedzy podręcznikowej. Na uwagę zasługuje jednak eksponowanie aspektu społecznego. I tak kapitalizm wolnokonkurencyjny funkcjonował $\mathrm{w}$ oparciu o działalność indywidualnych przedsiębiorstw, wolnej konkurencji i wolnego najmu, natomiast nie zapewniał ochrony prawnej robotnikom. Grabski głosił pochwałę kapitalizmu: „Dalszy rozwój kapitalizmu w tych warunkach zwiększył dobrobyt jednostki, zmniejszył przepaść między bogatym a biednym. Równocześnie zaznacza się wzrost higieny, zmniejszenie śmiertelności. W następnych stadiach rozwoju kapitalizm przejął wiele cech właściwych poprzednim kierunkom, jak pewna troska o konsumentów, wyodrębnienie gospodarki narodowej z ogólnej gospodarki świata. Niekiedy kapitalizm dla dobra producenta bezpośrednio, a konsumenta pośrednio ogranicza produkcję jak miało to miejsce w Ameryce Północnej"10.

Dostrzegał też negatywne skutki systemu kapitalistycznego. Zwrócił uwagę, że postęp gospodarczy, będący własnością całej ludzkości, przejął „kapitalizm dla silnych ekonomicznie jednostek, kosztem olbrzymiej większości pozostałych członków społeczeństwa"11.

W dobie kapitalizmu wolnokonkurencyjnego wyodrębniał jeszcze okres liberalizmu gospodarczego. Zaznaczał, że z zasad liberalnych mogły korzystać „albo bogate jednostki, albo silne państwa”. Państwem takim była Anglia ${ }^{12}$. W innym miejscu wyraził dość odmienną ocenę, a mianowicie, że „liberalizm przyznaje wprawdzie przewagę dużym przedsiębiorstwom, ale żąda także umożliwienia egzystencji i małym"13.

${ }^{9}$ W. Grabski, Polityka ekonomiczna. Skrypt z wykładów Prof. Władysława Grabskiego, Warszawa 1938, s. 5-6.

${ }^{10}$ Ibidem, s. 6.

${ }^{11}$ Ibidem, s. 3.

${ }^{12}$ Ibidem, s. 5.

${ }^{13}$ Ibidem, s. 4. 
Pisał, że w gospodarce monopolistycznej „szereg jednostek rządzi kapitałem za pośrednictwem zarządu". Powstają kartele i trusty regulujące produkcję i przeciwdziałające wolnej konkurencji i spadkowi cen, zwłaszcza w okresie złej koniunktury. Grabski wyrażał się z uznaniem o działalności monopoli, szczególnie w kontekście walki z kryzysami. Podkreślał, że jednocześnie dokonał się postęp w położeniu klasy robotniczej, np. ograniczono czas pracy, poprawie uległy warunki pracy, a ubezpieczenia oparto na zbiorowych umowach. Reasumując oceniał jednak, że interesy karteli i trustów były najczęściej sprzeczne z interesami ogółu obywateli ${ }^{14}$.

Grabski podkreślał, że w najnowszym okresie kapitalizmu, tj. w latach trzydziestych XX w., dokonały się istotne zmiany w gospodarce rynkowej. Nastąpiła demokratyzacja kapitalizmu. Pojawiły się tendencje umożliwiające rozwój „słabszym jednostkom"15.

W. Grabski przeciwstawiał się teoriom, które zapowiadały zmierzch kapitalizmu. Lansowali je zwłaszcza przedstawiciele socjalizmu. Według niego, chociaż „kapitalizm nie wkroczył głęboko w życie ludzkości, to jednak nie kończy się, gdyż właściwie dopiero się zaczął" ${ }^{16}$. Ocena okazała się nader trafna. Od tej wypowiedzi minęło więcej niż 7 lat, a gospodarka rynkowa, mimo licznych perturbacji, wciąż trwa.

W. Grabski zdawał sobie jednak sprawę ze słabych stron systemu kapitalistycznego. Jego obawy budziły przede wszystkim przeciągające się kryzysy ekonomiczne oraz nadmierny wyzysk ludności pracującej. Z tego też względu zainteresował się bliżej Kapitatem Karola Marksa. Teoria Marksowska nie miała na Grabskiego ani pozytywnego, ani negatywnego wpływu - jak słusznie ocenia Kazimierz Korab ${ }^{17}$. Traktował ją w kategoriach zagrożenia i odrzucał jej całościową koncepcję. Marksizmem interesował się na poziomie twierdzeń szczegółowych, mając świadomość powagi zjawiska. Przestudiował Kapitał i sporządził obszerne notatki, o czym donosił bratu w liście z $24.04 .1928 \mathrm{r}^{18}$ Streścił szczegółowo (na 55 stronach) poglądy Marksa dotyczące głównie pieniądza, kapitału, wytwarzania wartości dodatkowej, akumulacji pierwotnej oraz relacji kapitalista - robotnik $^{19}$.

\footnotetext{
${ }^{14}$ Ibidem, s. 5.

${ }^{15}$ Ibidem.

${ }^{16}$ Ibidem, s. 4.

${ }^{17}$ K. Korab, Władysław Grabski jako socjolog wsi, Warszawa 2004, s. 31.

${ }^{18}$ AAN, Akta Władysława Grabskiego, sygn. 1. List z 24.04.1928 r.

${ }^{19}$ AAN, Akta Władysława Grabskiego, sygn. 16. Karol Marks, k. 328-383.
} 
Grabski interesował się w szczególności tymi fragmentami Kapitału, które odnosiły się do stosunków społecznych. Według Marksa, rozwój kapitalizmu przyniósł postęp $\mathrm{w}$ dziedzinie produkcji, ale korzyści odnieśli tylko właściciele środków produkcji. Fabryki stały się ,jaskinią wyzysku wszelkich sił człowieka”. Grabski zanotował: „Bieda zatem wzrasta wraz z bogactwem. Ogólne prawo kapitalistycznego gromadzenia zasadza się na tem, że coraz więcej można wyprodukować z coraz mniejszym wydatkiem siły ludzkiej: pogarsza dolę robotnika, kapitał zwiększa zatem uciśnienie klasy robotniczej i zwiększa jej liczbę, liczbę zaś kapitalistów zmniejsza i wzbogaca ich [4 wyrazy nieczytelne] i przepaść między kapitalistami a robotnikami powiększa się..."20.

W. Grabski, któremu bardzo bliska była problematyka agrarna, zwrócił też uwagę na konstatacje Marksa dotyczące wpływu wielkiego kapitału na rolnictwo. Podkreśla on, że kapitalistyczna produkcja „,nadużywa i niszczy rolę”. Rozwija wprawdzie technikę (chodzi tu o maszyny rolnicze), ale jednocześnie, rujnuje źródła wszelkiego bogactwa: ziemię i robotnika"21.

Nie ulega wątpliwości, że Grabski akceptuje w pełni twierdzenia Marksa odnoszące się do wpływu na produkcję warunków naturalnych. Rozwinięcie tej kwestii odnajdujemy bowiem w jego przyszłych pracach. Zagadnienie to można streścić następująco. Postęp produkcji społecznej zależy od naturalnych warunków, które sprowadzają się do natury człowieka i przyrody. Na przyrodę zaś składają się bogactwa naturalne i „bogactwa naturalne narzędzi pracy”. W początkach cywilizacji główną rolę odgrywały pierwsze czynniki, później drugie. Ojczyzną kapitalizmu jest strefa umiarkowana. Decyduje o tym nie bezwzględna urodzajność gruntów, ale różnorodność jego własności chemiicznych, jego budowy geologicznej i topografii oraz rozmaitość wytwórców. Powyższe czynniki stanowią naturalną podstawę społecznego podziału pracy i pobudzają człowieka do działania ${ }^{22}$.

Kończąc sporządzanie notatek napisał: „możemy wywnioskować, że kapitał sprowadzając krańcowość społeczną do ostatnich granic przybliża godzinę śmierci monopolu kapitału własności kapitalistycznej. Następuje wtedy wywłaszczenie wywłaszczycieli” ${ }^{23}$. W procesie tworzenia kapitalizmu „szło o wywłaszczenie masy przez garstkę, teraz na odwrót będzie szło o wywłaszczenie garstki przez ogół"24. Grabski, zwracając uwagę na to zagrożenie, ostrzegał polityków i przedsiębiorców przed totalnym załamaniem systemu kapitalistycznego. Potwierdzenie

\footnotetext{
${ }^{20}$ Ibidem, k. 380.

${ }^{21}$ Ibidem, k. 363.

22 Ibidem, k. 364.

${ }^{23}$ Ibidem, k. 382; sygn. 2, k. 40-41.

${ }^{24}$ Ibidem, k. 383.
} 
tej obawy odnajdujemy w liście do Stanisława z maja 1937 r. Chwali w nim brata, że „najlepiej omówił” w X tomie cyklu opracowań kapitalne zagadnienie, a mianowicie: „czy kryzys obecny zwiastuje koniec ustroju opartego na prywatnej własności?" 25 . W. Grabski podzielał zasadniczo racje wyrażone przez bardziej radykalnego brata. S. Grabski przedstawił ewolucję systemu kapitalistycznego oraz bardzo trafną wizję rozwoju gospodarki rynkowej ${ }^{26}$.

\section{Determinanty dochodu narodowego}

Ekonomiści od dawna zastanawiali się nad czynnikami determinującymi poziom i wzrost gospodarczy. Na szczególną uwagę zasługują dwa ujęcia: podażowe i popytowe. W ujęciu podażowym, wywodzącym się z teorii neoklasycznej, przyjmuje się, że rozmiary dochodu narodowego są determinowane przez możliwości wytwórcze. Natomiast ujęcie popytowe, rozwinięte przez J. M. Keynesa, zakłada, że rozmiary rzeczywiste produkcji i dochodu narodowego zależą od efektywnego popytu na dobra i usługi.

W. Grabski opowiadał się za czynnikiem popytowym. Nie mógł wprawdzie znać Ogólnej teorii zatrudnienia, procentu i pieniadza (1936), ale jego poglądy są zbieżne z teorią J. M. Keynesa ${ }^{27}$. Generalnie zgadzał się z tezą, że wzrost siły nabywczej społeczeństwa jest czynnikiem zapewniającym wzrost gospodarczy. Zwiększeniu popytu służy podnoszenie płac realnych, a z kolei większe zarobki wpływają na poziom konsumpcji. Grabski pisał: „Podniesienie realne uposażeń i płac w okresach normalnych rozszerza rynek krajowy, stwarza zwiększony popyt i sprzyja przeto produkcji. Takie podniesienie płac jest tak samo korzystne dla produkcji, jak i podniesienie zdolności konsumpcyjnej wsi, co dziś jest

${ }^{25}$ Ibidem, sygn. 2, k. 40-41.

26 S. Grabski twierdził, że współczesny kapitalizm, obok tendencji upaństwowienia gospodarki rynkowej „ma międzynarodową tendencję do utworzenia systemu gospodarczego współżycia społeczeństw pod kierownictwem koncernów bankowych". Uważał, że ustrój kapitalistyczny nadal się przeobraża i że stan obecny nie jest ostatecznym etapem jego rozwoju. Ustrój ten ,,jest bardziej elastycznym od jakiegokolwiek poprzedniego”. Jego zdaniem rozpoczął się trzeci okres dziejów kapitalizmu. Będzie się on charakteryzował większym zróżnicowaniem typów kapitalistycznego ustroju w poszczególnych krajach, pogłębieniem się różnic w „uwarstwieniu społecznym", różnicach w polityce ekonomicznej i socjalnej, stosunku gospodarki prywatnej do publicznej, rozmiarach interwencjonizmu państwowego, większym wpływie robotniczych związków zawodowych, naśladownictwie w niektórych krajach polityki Związku Sowieckiego (S. Grabski, op.cit., t. X, s. 67, 69 i 97-126).

${ }^{27}$ J. M. Keynes, Ogólna teoria zatrudnienia, procentu i pieniądza, Warszawa 1956. 
powszechnie wysuwane, jako najlepszy sposób ożywienia przemysłu. Stany Zjednoczone Ameryki Północnej od dawna znajdują w podnoszeniu płac podstawę dla wzrostu ogólnego dobrobytu, a ponieważ wraz z tym podnoszeniem idzie w tym kraju wzrost wydajności pracy, koszty produkcji się nie podnoszą, a rynek krajowy dla zbytu wytworów produkcji się rozszerza"28.

Odnosząc się do sytuacji w kraju stwierdził, że wzrost płac realnych w 1924 r. nie wpłynął na podniesienie zamożności ludności. Niesprawdzenie się tej zależności upatruje w specyficznej sytuacji gospodarki polskiej ${ }^{29}$. Uważał on, że gospodarce polskiej zaszkodziła nadmierna konsumpcja całego społeczeństwa (wszystkich warstw społecznych) w latach 1924-1925, zwłaszcza konsumpcja luksusowa (import samochodów, cytrusów, mąki pszennej sprowadzanej z USA) ${ }^{30}$. Reforma walutowa wpłynęła na zwiększenie siły nabywczej społeczeństwa, szczególnie odnosiło się to do towarów importowanych. Kupowali ludzie (z różnych warstw społecznych), kupowały instytucje centralne i wojewódzkie. Zapasy walut zagranicznych szybko topniały, co wpłynęło m.in. na załamanie się złotego. W. Grabski konkludował: „Konsumpcja nadmierna psuje bilans i grozi walucie, konsumpcja niedostateczna kurczy rynek krajowy i sprowadza zastój. Zachowanie właściwej miary jest jedną $\mathrm{z}$ kardynalnych podstaw zdrowia społeczeństwa i siły państwa. Wymaga ono stanu równowagi w całym szeregu czynników, a przede wszystkim równowagi między produkcją a konsumpcją... Zmniejszenie konsumpcji może być złem koniecznym, ale jest złem"31. Zatem pogląd ten nie pozostaje $\mathrm{w}$ sprzeczności $\mathrm{z}$ generalną zasadą przyjętą $\mathrm{w}$ teorii ekonomii.

${ }^{28}$ W. Grabski, Dwa lata pracy u podstaw państwowości naszej (1924-1925), Warszawa 1927, s. 313.

${ }^{29}$ „A nie dokonał on tego nie tylko dlatego, że temu podnoszeniu się płac nie towarzyszył wzrost wydajności pracy, ale głównie dlatego, że produkcja krajowa w okresie poinflacyjnym znalazła się w obliczu specjalnych zupełnie trudności wynikających z drożyzny kredytu, będących skutkiem braku kapitału ruchomego zniszczonego w okresie inflacji. W takich warunkach potrzebą ogólną kraju było nie tyle rozszerzenie wewnętrznej pojemności rynku, co przyspieszenie procesu kapitalizacji. Proces ten doznałby przyspieszenia, gdyby konsumenci żyjący z płac i zarobków, zamiast rozszerzać swoją konsumpcję, odkładali w postaci oszczędności różnice w realnej wartości swoich płac w 1924 r., w porównaniu z latami poprzednimi” (ibidem).

${ }^{30}, \mathrm{~W}$ roku nieurodzajnym na zboża, a urodzajnym na kartofle nie zastępowano pierwszych tymi ostatnimi, tylko sprowadzano jak najwięcej najdroższego produktu zbożowego, gdyż mąki pszennej, i to najwyższych gatunków. Ze wzmożonej zdolności konsumpcyjnej ludności żyjącej z płac i zarobków nie skorzystała produkcja krajowa, uginająca się pod ciężarem drożyzny kredytu i klęski nieurodzaju, a tylko produkcja zagraniczna" (ibidem).

${ }^{31}$ Ibidem, s. 315. 
Należy tu wyraźnie podkreślić, że bardzo biedni mają poważne problemy $\mathrm{z}$ utrzymaniem konsumpcji na przyzwoitym poziomie. Polska w okresie międzywojennym była biednym krajem. Ludzie wydawali często więcej niż zarabiali, pokrywając różnice przez zadłużanie lub „przejadanie” wcześniej zgromadzonych oszczędności. Dotyczy to również krajów zamożnych ${ }^{32}$.

Wprawdzie w latach 1930-1935 postępował w Polsce wzrost płac realnych, ale nie poprawił on zdolności nabywczej ludności pracującej. Okazało się, że z powodu wysokiego bezrobocia realne dochody grupy pracowniczej spadły ${ }^{33}$.

Uwagi W. Grabskiego dotyczące wpływu efektywnego popytu na rozmiary dochodu społecznego, zawarte w pracy opublikowanej w 1927 r., należy uznać za bardzo interesujące. Wypływają z nich dwa wnioski: 1) badania empiryczne są często bardziej przydatne dla praktyki gospodarczej niż kierowanie się zasadami teoretycznymi; praktyka nie musi zgadzać się z teorią, 2) dochód narodowy determinują różne uwarunkowania i czynniki. Warto zauważyć, że badania ekonomistów w Polsce dotyczące dochodu narodowego znajdowały się w tym czasie w powijakach. Michał Kalecki i Ludwik Landau pierwsi obliczyli dochód za rok 1929 dla całego kraju ${ }^{34}$.

\section{Inwestycje}

Władysław Grabski przykładał dużą wagę do rozbudowy infrastruktury. Uważał, że w pierwszej kolejności należy przystąpić do budowy dróg. Pisał: „Mamy trochę budynków szkolnych luksusowo postawionych, ale szalony brak najzwyklejszych sal szkolnych, jako tako przyzwoicie wyglądających. Przede wszystkim mamy za mało dróg kołowych, jako tako możliwych.

Ze wszystkich inwestycji ta ostatnia jest gospodarczo najbardziej uzasadniona. Dobra droga przysparza produkcję rolną, ułatwia aprowizację miast i podnosi całą kulturę kraju. Wiadomo to od lat dawnych. Setki lat temu inne kraje już forsowały budowę dróg. Dziś te kraje stoją na czele cywilizacji" ${ }^{35}$.

W pracy Celowy Zwiazek Inwestycyjny Samorzadów Powiatowych rozwinął plan przeprowadzenia masowych inwestycji najważniejszych dla wsi polskiej, a mianowicie: budowy sieci dróg i melioracji ${ }^{36}$.

\footnotetext{
${ }^{32}$ Por. P. A. Samuelson, W. D. Nordhaus, Ekonomia 1, s. 203.

33 „Miesięczne Tablice Statystyczne” 1938, nr 7, s. 3-4.

${ }^{34}$ M. Kalecki, L. Landau, Szacunek dochodu społecznego w roku 1929, Warszawa 1934.

${ }^{35}$ W. Grabski, Dwa lata pracy..., s. 342.

${ }^{36}$ W. Grabski, Kultura wsi polskiej i nauczanie powszechne, Warszawa 1929, s. 5.
} 
Rząd oraz instytucje publiczne nie powinny godzić się na finansowanie „rzeczy niepotrzebnych”. W tej sprawie, twierdził W. Grabski, wszyscy muszą się kontrolować. „Nie przestaniemy być biedni, gdy sami godzić się będziemy na to, byśmy byli «błyszczący» nędzą. Nędzę naszą widzimy na każdym kroku...”. W związku z tym z budżetu należało finansować tylko najbardziej niezbędne inwestycje, tj. „Drogi bite, budynki szkolne proste, ale dla potrzeb nauczania odpowiednie, mieszkania dla ludności robotniczej w miastach, kanalizacja i uporządkowanie przedmieść, domy schroniska dla ubogich żebraków - są to rzeczy na Zachodzie dawno bardzo, bo przeszło pół wieku temu pozaprowadzane. Dzisiejsze pokolenie na Zachodzie nie pamięta wysiłków tego, które walczyło $\mathrm{z}$ niedostatkami na tle spraw powyższych. Walczyło ono tam z nimi w połowie XIX wieku i podniosło kraje Zachodu na pewien poziom kultury, do którego nam daleko. Czyż my możemy sądzić, że można te sprawy pomijać i myśleć o równaniu się z Zachodem w sprawach ogólnych politycznych czy ekonomicznych? Najpierw trzeba systematycznie kroczyć po linii wytwarzania kultury mas, a wtedy dopiero można się stać prawdziwą potęgą" ${ }^{37}$.

Pogląd Grabskiego dotyczący alokacji inwestycji ma nadal rację bytu we współczesnej teorii ekonomii ${ }^{38}$.

W związku z tym, że pieniędzy w kasie państwowej było zbyt mało sprzeciwiał się budowie, za pieniądze rządowe, piekarń mechanicznych, elewatorów i mleczarni. „I zadawał pytanie, dlaczego, jeśli te inwestycje mają się opłacać, nie pójdzie na nie kapitał prywatny?"39. Z góry był przekonany, że jeśli będą one realizowane przez kapitał państwowy, to będą nieopłacalne. W tym przypadku premier określił się jako zdecydowany liberał.

W 1936 r. W. Grabski oświadczył, że akcja inwestycyjna na wsi załamała się. Podawał, że główną przyczyną były wysokie koszty inwestycji, brak należytego nadzoru finansowego przez spółki oraz często mało przemyślane projekty ${ }^{40}$. Premier Grabski przykładał ogromną wagę do inwestowania w szkolnictwo i naukę - od szkoły powszechnej do wyższych uczelni. Podniesienie poziomu oświaty i kwalifikacji zawodowych uważał za podstawowy i niezbędny warunek rozwoju gospodarczego kraju. W książce $O$ własnych siłach poświęcił temu

${ }^{37}$ W. Grabski, Dwa lata pracy..., s. 344.

${ }^{38}$ Zdecydowanie wypowiedzieli się w tej kwestii P. A. Samuelson i W. D. Nordhaus. Podkreślają oni, że niepotrzebne, drogie inwestycje w krajach biednych są ,przejawem próżności i ekonomicznego szaleństwa. Są to raczej luksusowe ozdoby aniżeli rzeczy niezbędne do wzrostu gospodarczego" (P. A. Samuelson, W. D. Nordhaus, Ekonomia 2, Warszawa 1996, s. 405).

${ }^{39}$ W. Grabski, Dwa lata pracy..., s. 342.

${ }^{40}$ W. Grabski, Przeludnienie wsi $i$ wiejski plan inwestycyjny, „Gospodarka Narodowa” 1936, nr 21, s. 303. 
zagadnieniu rozdział zatytułowany Wychowanie publiczne jako czynnik sanacji gospodarczej. Wypowiedział w nim bardzo ważkie słowa: „Silniejszym i bardziej gruntownym od wpływu opinii publicznej i sfer rządzących czynnikiem, urabiania charakteru i usposobienia mas ludności jest wpływ wychowania publicznego. Jest to proste i zrozumiałe. A nie widzi się wcale troski publicznej o to, by szkoły nasze urabiały masy ludności w kierunku gospodarczo pożądanym. Świadomości nawet tego, że to jest zadaniem szkoły i że to jest jedną z konieczności naszego bytu narodowego na ogół nie widać. Od szkoły czy powszechnej, czy średniej wymaga się, by nauczyła dziecko możliwie dużo, ale żeby szkoła miała przygotować masy ludności do skutecznej rywalizacji z innemi narodami na polu walki życiowej, tego wcale się nie wymaga. A jednak trzeba się dobrze nad tem zastanowić, czy jest możliwem, by najbliższe pokolenie nasze mogło lepiej od nas samych wytrzymywać klęski i kryzysy gospodarcze, lepiej reagować na wypowiadanie nam wojen celnych, jeżeli wychowanie jego w szkole nie będzie szło w kierunku krzewienia cnót gospodarczych i urobienia takiej umysłowości, któraby usprawniała do walki życiowej na polu gospodarczem"41.

Ażeby spełnić ten cel, zalecał przeprowadzenie reformy szkolnictwa powszechnego na wsi. Sformułował 5 dyrektyw: 1) podręczniki szkolne i metody nauczania powinny być dostosowane do środowiska, tj. inne dla miast, inne dla wsi, a także zróżnicowane dla województw centralnych, zachodnich i wschodnich, 2) szkoła powinna kształtować uczniów myślących, aktywnych i zdolnych do pokonywania różnych przeciwności, 3) należało podnosić kwalifikacje nauczycieli, 4) dążyć do kształtowania producenta - „dzisiejsza szkoła dąży do urabiania konsumenta”, 5) kształtować zdolności do powiększenia wydajności pracy $^{42}$. Koncepcję nowej szkoły rozwinął w pracy Dwa lata pracy u podstaw państwowości naszej ${ }^{43}$.

${ }^{41}$ W. Grabski, O wlasnych sitach, Warszawa 1925, s. 94.

${ }^{42}$ W. Grabski, Dwa lata pracy..., s. 342.

43 „Szkoła musi wymagać wysiłków umysłu, musi wyrabiać zdolność do wysiłków we właściwym zakresie, a wytwarzać zamiłowanie do natężenia woli i umysłu jako ogólnego i podstawowego tła charakteru ludzkiego. Szkoła powszechna ma największe znaczenie dla urobienia charakteru gospodarczego ludzi. Ona ma większe znaczenie dla rozszerzenia umiejętności rolniczych od kółek rolniczych i odczytów dla ludu, bo gdy szkoła powszechna nie stworzy typu człowieka, który by miał skłonność do korzystania z wiedzy ludzkiej. Dwie trzecie Polaków to wieśniacy - drobni rolnicy. Dzieci ich pozostaną drobnymi rolnikami. Inaczej być nie może. Więc dla dwóch trzecich dzieci w całej Polsce szkoła powszechna powinna dawać to wszystko, co jest konieczne jako wstęp do tego, by przyszłe pokolenie drobnych rolników mogło i chciało dwa razy tyle produkować z jednostki przestrzeni roli, by umiało i chciało obracać owoce swojej pracy na podniesienie swego poziomu kulturalnego i na wzbogacenie państwa i społeczeństwa. W tym celu potrzeba urobić umysł i charakter wieśniaków. Trzeba wyrobić 
Grabski opracował szczegółowy system oświaty ludowej ${ }^{44}$. Miał on dwie zasadnicze cechy. Próbował skojarzyć w harmonijną całość oddziaływanie na ludność wiejską ziemiaństwa, kleru, szkół ludowych, organizacji samorządowych $\mathrm{w}$ celu włączenia chłopów w proces realizacji ponadklasowych, ogólnonarodowych zadań. System oświaty miał też na celu przekształcenie tradycyjnej psychiki chłopów, ukształtowanie cech charakteru właściwych nowoczesnemu, kapitalistycznemu przedsiębiorcy. System oświaty powinien przyczynić się do ukształtowania nowego typu rolnika-producenta o wysokich kwalifikacjach zawodowych.

Jak zawsze, i w tym przypadku, premier Grabski był bardzo konsekwentny i dalekowzroczny. W opracowaniu Kultura wsi polskiej zamieścił Projekt ustawy o budownictwie szkót powszechnych $w$ gminach wiejskich. Warunki lokalowe nauczania w szkołach wiejskich pozostawiały wiele do życzenia.

Wiedzę traktował jako źródło wszelkiego postępu. Z racji tego, że Polska była krajem z przewagą rolnictwa, a sam posiadał rozległą wiedzę i praktykę agrarną, koncentrował się na postępie w dziedzinie rolnictwa. Twierdził, że „trzeba będzie czynnikowi rozwoju umysłowego ludności oddać naczelne miejsce wśród przyczyn postępu" ${ }^{45}$. Na podstawie obserwacji sytuacji w rolnictwie duńskim, niemieckim, belgijskim, a zwłaszcza amerykańskim dowodził, że „szerzenie wiedzy rolniczej jest jednym z czynników ogólnoduchowych, które na produkcję rolną mają nie mniejszy wpływ od gleby, klimatu, podatków, ceny, kredytu"46.

W. Grabski wskazywał na potrzebę poznania natury rolnictwa. Pisał, że wiedza i postęp nie powinny być ślepymi sługami ducha przedsiębiorczości kapitalizmu. „Kryzys rolniczy jest pożytecznym tylko jako ostrzeżenie. Wiedza i postęp są duchowymi pomocnikami ludzkości społeczeństw i narodów tylko wtedy, gdy są poddawane krytyce naukowej. Wskazuje on, że rolnictwo nie jest tym samym co przemysł, że w rolnictwie działają wytwórczo siły przyrody, że kapitał ich nie zastępuje, że człowiek natomiast w rolnictwie w sobie samym posiada wielką moc wpływania na te siły, gdy opiera się o ich znajomość,

gruntowność usposobień, zamiłowanie do dokładności, ścisłości w rozumowaniu, pozytywnego ujmowania zjawisk przyrody, systematyczności i porządku. Jest to nadzwyczaj płodne pole pracy, by to wszystko wyrobić. Szkoły powszechne w Finlandii potrafiły zaszczepić te zalety charakteru plemionom fińskim, podczas gdy te same plemiona w Rosji pozostające odznaczały się brudem, niechlujstwem i ubóstwem" (W. Grabski, Dwa lata pracy..., s. 350).

${ }^{44}$ Szczegółowy opis systemu oświaty znaleźć także można w: W. Grabski, Materiały w sprawie włościańskiej, cz. III, Warszawa 1919, s. 7-70; idem, Zagadnienia polskiej polityki ekonomicznej, cz. 3 i 4, Warszawa 1929.

${ }^{45}$ W. Grabski, Historia wsi w Polsce, Warszawa 2004, s. 331.

${ }^{46}$ W. Grabski, Znaczenie czynników psychicznych w produkcji rolnej, Warszawa 1927, s. 7-8. 
czerpaną z bezpośredniego z przyrodą stosunku i wzmacnianą przez wiedzę rolniczą. Dlatego też wiedza w stosunku do rolnictwa wymaga szerokiej skali doświadczalnej i ciągłej styczności z życiem rolników. Widzimy, że tak jest w wielu krajach. U nas ten kontakt wiedzy z życiem wymaga mocniejszego utrwalenia" ${ }^{47}$. Namawiał również włościan do wykorzystywania czynników produkcji, które nie wymagają żadnych nakładów pieniężnych. Do tych czynników zaliczał inteligencję i rozumną pracowitość rolników oraz troskę o rośliny i zwierzęta. Nie wymagają one nakładów pieniężnych i ich wykorzystanie jest szczególnie istotne w okresach kryzysu. Zwracał uwagę, że w tej materii są w Polsce wielkie rezerwy ${ }^{48}$.

Premier W. Grabski w swojej twórczości i działalności publicznej domagał się należnego miejsca dla nauk ekonomiczno-rolniczych w gospodarce narodowej. Wypowiedzi jego $\mathrm{w}$ tej kwestii związane są przede wszystkim z problematyką kryzysów, w związku z czym znajdą swoje miejsce w dalszej części pracy.

\section{Rola czynnika pracy we wzroście gospodarczym}

W. Grabski w pismach i przemówieniach wielokrotnie podnosił znaczenie pracy jako ważnego czynnika dla rozwoju gospodarczego kraju, jego bezpieczeństwa zewnętrznego oraz podniesienia poziomu życia społeczeństwa. A oto jego credo w tej kwestii: „Bez ciężkiej pracy ogromnej większości społeczeństwa żaden kraj nie był nigdy silny i my nim nigdy nie będziemy. Świadomość tego musi wszędzie przenikać. Ciężka praca jest złym losem, gdy daje marne wyniki i liche wynagrodzenie. Ciężka praca umiejętnie użyta jest podstawą bogactwa ludzi i narodów, a jest ona taka, gdy jest opromieniona rozumem i gdy się dobrze opłaca. Obawiam się, że ogromna większość rozumuje tak, że na to człowiek się uczy, by ciężko nie potrzebował pracować. A gdy okazuje się to niemożliwe, następuje rozczarowanie i zniechęcenie do życia, do społeczeństwa, do rządu i do państwa własnego. Ciężko powinien pracować nie tylko włościanin i robotnicy, ale i pracodawcy, każdy w swoim zakresie. Ciężka praca to taka, w którą się wkłada duży nakład wysiłku.

Wysiłków większych niż te, które dziś dajemy, potrzebujemy nie tylko w pracy gospodarczej, ale i intelektualnej, artystycznej i wszelkiej innej. Nie tworzy się nic bardziej wartościowego bez większego wysiłku. Unikanie wysiłków to spadanie w dół w życiu cywilizacyjnym" ${ }^{49}$.

\footnotetext{
${ }^{47}$ W. Grabski, Kultura wsi polskiej..., s. 60-62.

48 Ibidem, s. 15.

${ }^{49}$ W. Grabski, Dwa lata pracy..., s. 349-350.
} 
Ubolewał, że świadomości tej konieczności w gronie państwowym, niestety, nie widzimy prawie wcale. Opinia publiczna nie zdradzała również - jego zdaniem - w tej dziedzinie zrozumienia i nie zdawała sobie sprawy, że możemy być $\mathrm{z}$ powrotem poddani rozbiorom. Rządzący i społeczeństwo powinni więcej dawać $\mathrm{z}$ siebie, bo inaczej mocarstwa wchłoną nas, jako bierną masę, do swych organizmów państwowych. Dalsza argumentacja Grabskiego jest utrzymana w podobnym duchu ${ }^{50}$.

W. Grabski doceniał pracę fizyczną. Twierdził, że w warunkach polskich „dobrze jest położyć duży nacisk na ważność i dostojeństwo pracy fizycznej”, gdyż u nas zauważa się często „wschodnie” lekceważenie i pogardę dla wszelkiej pracy. Jednak uważał, iż najważniejszym czynnikiem produkcji jest praca umysłowa, jako najbardziej twórcza i wydajna.

Niestety, pisze dalej, „lud nasz mało ceni pierwiastek intelektualny w życiu gospodarczym. Zajęcia w polu, czy w obejściu, często wykonuje mechanicznie, a nawet bezmyślnie" 51 .

We współczesnej nauce ekonomii podkreśla się niezmiennie wagę wykształcenia: „Ludzie wykształceni pracują wydajniej. Inwestują wobec tego w szkolnictwo i inne programy... Oprócz czytania i pisania uczą ludzi nowych technik rolniczych i przemysłowych" ${ }^{2}$.

Słowa krytyki kierował też do klasy posiadającej. Twierdził mianowicie, że z posiadanych warsztatów nie potrafią osiągać dochodów. Nie umieją sami gospodarować, nie mogą się zdobyć na powierzenie majątków zdolnym zarządzającym, czy też oddawanie ich $\mathrm{w}$ dzierżawę ${ }^{53}$. Opowiadał się za poglądem Władysława Radwana, który domagał się odebrania klasom posiadającym monopolu na „urabianie duchowości” młodzieży. Trzeba wykształcić przekonanie wśród

50 „Od tej ewentualności nie obronią nas wcale wyższe zalety uduchowienia szczytów naszego społeczeństwa, jeżeli szary dół będzie indolentny i jeżeli tempo pracy wytwórczej będzie $\mathrm{u}$ nas tak słabe, iż szukać będziemy ochrony waluty w reglamentacjach, a ochrony produkcji w niskim budżecie państwowym. Marazm, który tego będzie musiał być wynikiem, podetnie nasze siły zupełnie i odbierze nam wiarę w to, byśmy byli zdolni oprzeć się jakimkolwiek poważniejszym niebezpieczeństwom. A wtedy nie uratujemy największego skarbu, jaki dziś posiadamy i którego nie doceniamy - naszej państwowości, naszego rządu polskiego. Rządy w Polsce będą dobre i silne, i dla społeczeństwa korzystne, gdy społeczeństwo będzie umiało tak pracować, by stać je było na utrzymanie naprawdę dzielnego aparatu rządzącego, cywilnego i wojskowego. Wtedy tylko będziemy mogli być co do naszej przyszłości bezpieczni” (ibidem, s. 320).

${ }^{51}$ W. Grabski, Kultura wsi polskiej..., s. 28.

${ }^{52}$ P. A. Samuelson, W. D. Nordhaus, Ekonomia 2, s. 395.

${ }^{53}$ W. Grabski, Dwa lata pracy..., s. 348. 
młodych ludzi, aby nie widzieli w każdym posiadaczu wyzyskującego pana. Aby temu zapobiec należało umożliwić młodzieży z ludu większy dostęp do wykształcenia ${ }^{54}$.

W. Grabski twierdził zdecydowanie, że polska inteligencja „nie stoi na wysokości zadania", lekceważy producentów i potrzeby ludu. Nastawiana jest bowiem „na odczuwanie intelektualizmu i czynnika konsumpcji”. Lud potrzebuje przede wszystkim wychowania w duchu przygotowania do mądrzejszej i bardziej wydajnej pracy oraz umiejętności współpracy z inteligencją. Podaje, jako wzór do naśladowania, postawy społeczeństwa duńskiego i czeskiego ${ }^{55}$.

Premier Grabski nawoływał do jedności ludu z inteligencją. Polska, argumentował, potrzebuje więcej niż inne kraje ,żywotności, zdolności do walki o byt, energii czynu". Tylko wspólna, zgodna praca wytwórcza całego społeczeństwa uczyni kraj silnym i bezpiecznym. Nie może być jednak rozdźwięków między ludem a inteligencją ${ }^{56}$. Uważał za konieczne zwiększenie wydajności pracy wytwórczej. Wzrost wydajności pracy był dla niego najważniejszym czynnikiem odrodzenia życia gospodarczego, „kredytowego i finansowego”. Wyrażał przekonanie, że największe zło, jakie gospodarce polskiej wyrządził okres inflacji, polegało na demoralizacji producentów. Zaczęli oni upatrywać źródeł swych dochodów nie w zwiększaniu wydajności pracy, a w spekulacji (na cenach towarów sprzedawanych i nabywanych). Premiera atakowano za to, że nie przeprowadził rewizji ustawodawstwa socjalnego. Ograniczenie zdobyczy socjalnych miało przynieść oszczędności budżetowe i wpłynąć na lepsze efekty produkcyjne. Grabski stał na stanowisku, że rewizja ustaw w tym zakresie nie może naruszyć podstawowych zdobyczy klasy robotniczej. Sam przyczynił się do rozwoju ustawodawstwa socjalnego (zob. rozdz. I).

54 W. Radwan, Postulaty w sprawie ustroju szkolnictwa w Rzeczypospolitej Polskiej, Warszawa 1925, s. 20-21.

${ }^{55}$ W. Grabski, Kultura wsi polskiej..., s. 35.

56 „Dopóki lud będzie biedny, dopóki z własnego warsztatu nie potrafi wydobyć tyle, co Czech, Niemiec, póty inteligent, który wyszedł z ludu, nie będzie się czuł w środowisku ludowem jak u siebie, a lud nie będzie widział w nim swojego, a tylko obcego mu człowieka. Koloniści czescy na Wołyniu nie górują nad innym i, ani wielkością swojego posiadania gruntowego, bo wśród nich są dość liczni i małorolni nawet, nie górują tem, by kończyli wyżej zorganizowane szkoły, bo wśród nich wielu nie było w stanie nawet przejść kilku klas nauczania, ale górują oni bardzo silnie całą swoją kulturą materjalną i duchową przez nastawianie swojej duchowości na pracę wytwórczą, co wynieśli ze swojej ojczyzny, z której przybyli. Temu nastawieniu sprzyja to słabe szkolnictwo, jakie posiadają i cała kultura czeska z jakiej wyrośli i jakiej starają się pozostać wiernymi. Naszej kulturze polskiej musimy nadać tak samo nastawienie w kierunku wytwórczości. Nasza szkoła powszechna musi też temu nastawieniu być poświęcona” (ibidem, s. 33). 
Uważał, że główną przyczyną niskiej wydajności pracy nie jest ustawodawstwo, które było niewątpliwie wadliwe i wymagało naprawy, ale zespół uwarunkowań społeczno-administracyjnych. Podawał m.in. następujące przykłady: kasy chorych są źle administrowane i pochłaniają zbyt duże koszty, pomoc lekarska budzi niezadowolenie ludności, urlopy obowiązkowe są za długie, ośmiogodzinny dzień pracy $\mathrm{w}$ budownictwie $\mathrm{i}$ w zajęciach sezonowych nie daje się uzasadnić racjonalnie. Ten stan rzeczy przynosił negatywne skutki gospodarcze i społeczne. Podejmowane próby zmian napotykały jednak na opór poszczególnych partii politycznych i klasy robotniczej. Grabski zapytywał: ,jak zmienić ducha naszego narodu, kto ma to uczynić: rząd, samorząd, szkoła, stronnictwa, czy prasa?" 57 .

Największe możliwości wypełnienia tej misji widział w zreformowanej szkole powszechnej w mieście i na wsi. „Nastawiona być ona winna na to, by wytwarzać kandydatów na dzielniejszych producentów, musi przybrać podkład więcej realny, mniej humanistyczny, zawierać mniej subiektywizmu i liryki, a więcej pierwiastku woli i czynu, mniej uniwersalizmu, a więcej odbicia środowiska, mniej przeładowania wiadomościami powierzchownemu, a więcej dokładnego przyswojenia sobie rzeczy podstawowych" ${ }^{\text {"58 }}$.

Opis rzeczywistości przedwojennej uważam za bardzo trafny. Co więcej, gorzkie prawdy wypowiedziane 86 lat temu są w większości dzisiaj aktualne. Natomiast proponowana reforma szkolnictwa nie wytrzymuje konfrontacji z obecnymi zasadami pedagogiki. Podobnie, nie można się zgodzić ze stwierdzeniem, że praca włościan jest mało wydajna i ,na to żadne ustawodawstwo socjalne nie pomoże". Znamy przykłady, nawet z odległej historii, że chłopi otoczeni lepszą opieką, pracowali wydajniej na pańskim folwarku, np. w dobrach Anny Jabłonowskiej, Pawła Brzostowskiego, czy Andrzeja Zamojskiego ${ }^{59}$.

W. Grabski zwracał wielokrotnie uwagę, że pozycję państwa na arenie międzynarodowej zapewni przede wszystkim rozwój własnych sił produkcyjnych $^{60}$. Pożyczki zagraniczne nie zmienią stanu gospodarki, jeśli nie będzie

${ }^{57}$ W. Grabski, Dwa lata pracy..., s. 318-319.

${ }^{58}$ W. Grabski, Kultura wsi polskiej..., s. 27.

${ }^{59} \mathrm{~J}$. Skodlarski, Wybitni reformatorzy i kreatorzy polskiego pieniądza a ich oblicze moralne, t. I, Łódź 2009, s. 113-255.

60 „Przerobienie naszego społeczeństwa w duchu powyższych postulatów jest dla nas koniecznością dziejową. Bez granic naturalnych, w otoczeniu sił wrogich, nadzwyczaj silnych, bo stanowiących niebezpieczeństwo dla całego świata, nie będziemy mogli sami zachować naszej niepodległości, o ile nie podniesiemy się na ten wyższy poziom zdolności do życia zbiorowego, jaki już znamionuje społeczeństwa przodujące ludzkości i jaki jest jeszcze nam daleki i obcy" (W. Grabski, Dwa lata pracy..., s. 346). 
towarzyszył im wzrost wydajności pracy. Pieniądze „pójdą” na konsumpcję, mimo że formalnie będą przeznaczone na produkcję ${ }^{61}$. Taki stan rzeczy wystąpił $\mathrm{w}$ drastycznej formie w PRL ${ }^{62}$. Inną uwagę premiera Grabskiego również można odnieść do funkcjonowania gospodarki w tzw. Polsce Ludowej, a nawet w pewnym sensie do aktualnej sytuacji w III Rzeczpospolitej. W. Grabski konkluduje: w przemyśle nie doszło do przekształceń i „,dostosowań technicznych”63.

\section{Państwo, budżet, podatki}

Władysław Grabski, jako ekonomista, był liberałem. Zdecydowanie opowiadał się za wolnością gospodarczą. Uważał, że funkcje gospodarcze państwa powinny ograniczać się do ściśle koniecznych zadań, a rząd - winien popierać indywidualną i zbiorową inicjatywę ekonomiczną. Jego przekonania zweryfikowała dotychczasowa historia gospodarki kapitalistycznej. Dzisiaj również uważa się, że najważniejszą rolą państwa w gospodarce rynkowej winna stać się pomoc rynkom, aby działały bardziej efektywnie i przejrzyście. Zalecano i zaleca się obecnie zmniejszanie wydatków publicznych ${ }^{64}$. Mimo to mają one trend rosnący w krajach uprzemysłowionych - od kilku procent w II połowie XIX w. do kilkudziesięciu w latach 1960-2000. Vito Tanzi przekonuje, że państwa nie powinny wydawać więcej pieniędzy niż około $30 \% \mathrm{PKB}$, aby sfinansować swoje podstawowe cele społeczne i ekonomiczne ${ }^{65}$.

Grabski był przeciwny tworzeniu przedsiębiorstw państwowych. Twierdził, że państwo „w swojej gospodarce bardzo silny nacisk kładzie na zabezpieczenie przyszłości”. Rolę „ciał publicznych” sprowadzał do polityki ubezpieczeń społecznych, rozwoju oświaty, zapewnienia bezpieczeństwa wewnętrznego i zewnętrznego ${ }^{66}$.

Dowodził, że gospodarka publiczna nie podlega prawu, wynikającemu z pojęcia homo oeconomicus i zysk nie jest jej głównym motywem działania. Wydatki publiczne mają tak ,łatwo rozszerzające się granice”, że istnieje niebezpieczeństwo marnotrawstwa finansów skarbu państwa. Ze strony sfer kierowniczych

${ }^{61}$ Ibidem, s. 317-318.

${ }^{62}$ Zob. prace Janusza Kalińskiego, Zbigniewa Landaua, Wojciecha Roszkowskiego, Janusza Skodlarskiego i innych autorów.

${ }^{63}$ W. Grabski, Dwa lata pracy..., s. 318.

${ }^{64}$ V. Tanzi, Gospodarcza rola państwa w XXI wieku, [w:] Odkrywając wolność. Przeciw zniewoleniu umysłów, wyb. i wstęp L. Balcerowicz, Warszawa 2012, s. 645.

${ }^{65}$ Ibidem, s. 626-627.

${ }^{66}$ W. Grabski, Polityka ekonomiczna, s. 24. 
i poszczególnych partii dostrzegał rosnący nieustannie przerost żądań pod adresem państwa, przewyższający jego zdolność świadczenia na rzecz ogółu.

W. Grabski przeciwstawiał się silnym tendencjom etatystycznym w Polsce. Traktował je jako poważne zagrożenie dla gospodarki, a nawet dla funkcjonowania państwa. W jego przekonaniu nadmierny etatyzm hamował inicjatywy społeczne. Pisał: „W ogólnym przyjętym u nas światopoglądzie rząd jest wyolbrzymiany jako czynnik mogący wszystko regulować i opanować, naprawić albo popsuć... przy podnoszeniu rządu do nadnaturalnej potęgi, obarcza się go jedynie nadmierną odpowiedzialnością"67. Uważał, że „najgorszy z etatyzmów jest ten, który polega na stawianiu rządowi dużych wymagań" i oglądaniu się na pomoc państwa. Pod presją społeczną rząd musiał realizować przesadne roszczenia socjalne i utrzymywać liczne organizacje społeczne ${ }^{68}$.

Sam Grabski doświadczył, będąc premierem, sytuacji określanej mianem „błędnego koła”. Stan ten trafnie opisuje Frédéric Bastiat: „Jeśli odmówi [państwo] rzeczy, których się od niego domagają, zostaje oskarżone o niemoc, złą wolę i niezdolność. Jeśli usiłuje sprostać wymaganiom, musi uderzyć w ludzi zwiększonym podatkiem uczynić więcej zła niż dobra, i w inny sposób ściągnąć na siebie ogólną niechęć" ${ }^{69}$. Rząd Grabskiego i następne gabinety dość skutecznie ograniczały wydatki państwowe. W 1929 r. pochłaniały one około $7 \% \mathrm{PKB}^{70}$. Dla porównania w 1920 r. wydatki rządowe w Niemczech wynosiły $25 \%$ PKB, we Włoszech - 30,1\% PKB, w Hiszpanii - 8,3\% PKB i miały trend rosnący ${ }^{71}$.

Grabski szczególnie ostro krytykował politykę samorządów miejskich: „Gdy miasto chce mieć wszystko własne, wchodzi na złą drogę i marnuje pieniądze podatnika w realizowaniu najskrajniejszego etatyzmu, jaki tylko być może. Powinna być ustalona z góry zasada, że na żadne inwestycje miejskie, które mają wyręczać to, co mogą zrobić sami obywatele, rząd nie powinien dawać żadnych kredytów. Ulegać presji bezkrytycznych petycji i delegacji, dla których jedynym celem jest znalezienie pretekstu, by sięgać do kieszeni skarbu lub banków rządowych, jest to szkodliwym dla całego społeczeństwa marnotrawstwem grosza publicznego" $" 72$.

W. Grabski, będąc ministrem skarbu (1919), wyraził przekonanie, że wolny rynek jest zdolny „przywrócić zwiększenie zaofiarowania wszystkiego czego brak”, ale „sytuacji tak trudnej, jak obecna, nie można rozwiązać żadną określoną

\footnotetext{
${ }^{67}$ W. Grabski, Najszkodliwszy z etatyzmów, „Drogi Naprawy” 1926, nr 3, s. 4-6.

${ }^{68}$ Ibidem, s. 6.

${ }^{69}$ F. Bastiat, Państwo, [w:] Odkrywając wolność..., s. 354.

${ }^{70}$ Mały Rocznik Statystyczny 1939, s. 376. Obliczenia własne.

${ }^{71}$ Zob. szerzej: V. Tanzi, op.cit., s. 626-627.

${ }^{72}$ W. Grabski, Dwa lata pracy..., s. 345.
} 
formułą"73. Dopuszczał zatem możliwość różnorodnych działań, nie zawsze zgodnych $\mathrm{z}$ przyjętą teorią, $\mathrm{w}$ tym także ingerencję państwa $\mathrm{w}$ gospodarkę rynkową ${ }^{74}$. Przestrzegał przed ,skutkami powszechnej wolności” w kraju, w którym produkcja jest niedostateczna w stosunku do niezbędnej konsumpcji ${ }^{75}$.

Rząd i aparat państwowy powinien mieć wsparcie całego społeczeństwa. Grabski uświadamiał, że „los nasz jest przede wszystkim w naszych własnych rękach”, a warunkiem suwerenności państwa jest „rodzima myśl twórcza” i silna gospodarka. Dopuszczał możliwość korzystania z pomocy zagranicznej, ale pod warunkiem nieulegania „cudzemu przewodnictwu”. Apelował, aby „podnieść” skarb, walutę, kredyt i produkcję, uważając to za niezbędny warunek przetrwania na wypadek burz dziejowych ${ }^{76}$.

Premier Grabski w działalności publicznej i swym piśmiennictwie powtarzał wielokrotnie, jak mantrę, że „musimy przerobić zbiorową duchowość naszego ogółu i jego sił kierowniczych intelektualnych. [...] Zwiększyć wydajność na wszystkich polach, nie oglądać się na niczyją pomoc, płacić uczciwie podatki, oszczędzać i gromadzić środki do dalszej produkcji oraz zwiększyć odporność na trudne momenty w kraju"77.

Warunkiem zajęcia przez Polskę wysokiej pozycji w świecie był wspólny wysiłek całego społeczeństwa ${ }^{78}$. W latach 20 . W. Grabski wierzył w solidarną, zbiorową pracę polskiego społeczeństwa. Przykładał dużą wagę do czynnika

${ }^{73}$ W. Grabski, Projekt programu polityki ekonomicznej i finansowej po wojnie, Warszawa 1920, s. 19.

${ }^{74}$ Ibidem.

75 „Oczywiście sprowadzonoby brakujące przedmioty z zagranicy, a cena krajowych towarów podniosłaby się do wysokości zagranicznych. Drożyzna przez to jednak podniosłaby się tylko, a ponieważ przy wwozie z zagranicy produkcja krajowa nie mogłaby się rozwinąć, więc spadek waluty byłby nieustanny i zawrotnie szybki. Spadek ten doszedłby do takich rozmiarów, aż kraj stałby się zupełnie ubogim na to, by nastarczyć sprowadzać z zagranicy nawet rzeczy najniezbędniejszych. Oczywiście w tych warunkach nie byłoby mowy o tem, by kapitał zagraniczny chciał i mógł przyjść ożywić wytwórczość krajową. Kapitał ten najwyżej wykupywałby oczywiście pozostałe jeszcze w kraju bogactwa". Ibidem.

${ }^{76}$ W. Grabski, Dwa lata pracy..., s. 354.

77 Ibidem, s. 345.

78 „A więc spieszyć się musimy, by nie być zaskoczeni. A więc wysilać się musimy, by nie być zdystansowani. A więc zespalać się winniśmy, by nie być cudzą przewagą zmiażdżeni. A więc wznosić ducha własnego winniśmy, by nie być poniżeni. A gdy każdą chwilę, każdy czyn i każdą myśl naszą skierujemy ku spełnieniu tego, czego Opatrzność od nas wobec Ojczyzny wymaga, nie żal nam będzie naszych trudów i wysiłków, bo obrócą się one na sprawę najdroższą, jaka być może: zapewnienie naszemu państwu takiego miejsca na świecie, które by dało pełny wyraz sił ducha ludzkiego tkwiących w narodzie naszym" (ibidem, s. 355). 
społecznego. Szczególną rolę w rozwoju wsi i rolnictwa miała odegrać samorządność wiejska, wypełniając obowiązki oświatowe, socjalne i gospodarcze (opieka nad ubogimi, bezpieczeństwo publiczne, melioracje itp.). Ważną misją obarczał działaczy chłopskich, którzy mieli organizować życie społeczne i wyzwalać energię mieszkańców wsi ${ }^{79}$. W końcu lat 30., obserwując sytuację w Polsce, rozgoryczony pisał: „Ale nie widzę w społeczeństwie naszem sił twórczych gospodarczo o podkładzie indywidualistycznem. Niestety lud nasz tych sił nam daje za mało, a klasy wyższe prawie wcale" ${ }^{\text {. }}$

Podstawą dochodów skarbu państwa były podatki. W 1920 r. wprowadzono jednolity podatek dochodowy dla całego kraju. Poziom polskiego prawodawstwa podatkowego dorównywał najbardziej postępowym systemom podatkowym w krajach Europy Zachodniej.

Gros dochodów przynosiły podatki bezpośrednie, w tym najwięcej - podatek dochodowy. Istotną pozycję stanowiły podatki pośrednie, obciążające towary i usługi ${ }^{81}$.

W. Grabski uważał podnoszenie stawek podatków za posunięcie niezawodne. Zdawał sobie sprawę, że zwiększenie podatków musi wpłynąć na zmniejszenie wydatków konsumpcyjnych. Natomiast konieczna była - jego zdaniem - zmiana rozłożenia podatków. Uważał za konieczne zwiększenie globalnej kwoty dochodów. „Przy dzisiejszej stopie dochodów państwowych my jako państwo między Niemcami i Rosją się nie utrzymamy. W tej sprawie, albo Sejm okaże się wielkim Sejmem reform gospodarczych i skarbowych, a więc i podatkowych, albo musi nastać w Polsce okres takich pełnomocnictw dla rządu, ażeby mógł on objąć wszystkie ustawodawstwa i podatkowego i socjalnego" pisał pełen obaw o przyszłość Polski ${ }^{82}$.

Nie miał przekonania do podatków bezpośrednich; za lepsze uznawał podatki pośrednie ze źródeł konsumpcyjnych. Były one bardziej odpowiednie, zwłaszcza w pierwszych latach powojennych, proste i przynosiły szybko dochód $^{83}$. Zalecał podniesienie podatków konsumpcyjnych m.in. od nafty, piwa, drożdży, zapałek, wód mineralnych i innych towarów.

${ }^{79}$ W. Grabski, Historia wsi..., s. 319-331. Cenne uwagi na ten temat przedstawił K. Korab, op.cit., s. 244.

${ }^{80}$ AAN, Akta Władysława Grabskiego, sygn. 2, k. 40. List Stanisława z dn. 5.07.1937 r.

${ }^{81}$ W latach 1938-1939 dochody z podatków bezpośrednich wyniosły $830 \mathrm{mln}$ zł, w tym podatku dochodowego - $343 \mathrm{mln}$ zł. W tym samym czasie suma podatków pośrednich osiągnęła $214 \mathrm{mln}$ zł. Ogółem dochody z podatków zamknęły się kwotą $2141 \mathrm{mln}$ zł (Mały rocznik statystyczny 1939, s. 380).

${ }^{82}$ W. Grabski, Dwa lata pracy..., s. 344.

${ }^{83}$ W. Grabski, Projekt programu..., s. 29. 
W systemie finansowym gospodarki polskiej ważną rolę odgrywał podatek majątkowy, nazywany też daniną. Podatek ten uchwalano w okresie międzywojennym kilkakrotnie. Szczególnie duże znaczenie miał podatek majątkowy zatwierdzony przez sejm w $1923 \mathrm{r}$. Wpływy z niego przyczyniły się do likwidacji hiperinflacji ${ }^{84}$. Premier w tak dramatycznej sytuacji gospodarczej kraju wykazał się determinacją w ściąganiu podatków. Dnia 16.02.1924 r. wydał rozporządzenie nakazujące egzekwowanie kar za każdy dzień zwłoki w płatności podatku dochodowego i przemysłowego $\mathrm{w}$ wysokości $0,5 \%$ kwoty należnego podatku ${ }^{85}$.

Pobór podatku majątkowego napotkał na znaczne trudności i przedłużał się czas ściągania go. W. Grabski uznał w 1925 r., że budżet państwa polskiego nie potrzebuje wysokiego podatku ze środków nadzwyczajnych. W związku z tym zaproponował reformę podatku majątkowego. Powinien on być - twierdził zredukowany do połowy globalnej wysokości uchwalonej w 1923 r. (1 mld franków w złocie). Zamiast drugiej połowy kwoty należało ustanowić stały roczny umiarkowany podatek majątkowy. Istotę tej zmiany Grabski tłumaczył następująco: „O co powinno chodzić przy poborze tego podatku? O to, żeby nie sięgał on do substancji majątkowej. Sięga on do substancji majątkowej wtedy, kiedy jest bardzo duży, z chwilą gdy jest mniejszy, nie sięga. W miarę wzrastania wartości obiektów majątkowych wydajność tego podatku będzie wzrastała"86.

Dotychczasowy podatek uważał za niesprawiedliwy ${ }^{87}$. Zawieszenie jego poboru - jak domagało się wielu właścicieli - traktował jako samobójstwo w sferze finansów publicznych ${ }^{88}$.

${ }^{84}$ Z. Landau, Podatek majątkowy, [w:] Encyklopedia historii gospodarczej Polski do 1945 r., Warszawa 1981, s. 89. Zob. też: W. Breit, Podatek majątkowy, Lwów 1924.

${ }^{85}$ W. Sułkowska, Twórcy polskiej myśli ekonomicznej: Władystaw Grabski, Kraków 1990, s. 105.

${ }^{86}$ W. Grabski, Program walki z kryzysem gospodarczym w Polsce, Warszawa 1925, s. 31.

87 „Podatek majątkowy obecnie skonstruowany jest podatkiem osobisto-majątkowym, to znaczy, że jeżeli ktoś w 1923 r. zadeklarował pewien majątek, to w ciągu 8 lat ta deklaracja majątkowa prześladowałaby go choćby on już majątku nie miał, a z drugiej strony, kto w ciągu 8-miu lat dorobił się majątku byłby wolny od podatku majątkowego - stworzyłaby się więc niesprawiedliwa sytuacja, która by spowodowała masę reklamacji. Wobec tego Rząd w ostatnich czasach zdecydował się wystąpić z projektem, ażeby podatek majątkowy obecnie obowiązujący, ograniczyć do połowy, nie wchodząc już w to, czy rolnictwo jest nim za dużo obciążone, czy przemysł mniej” (ibidem, s. 30).

${ }^{88}$ Rozpowszechniło się mniemanie, że nasz system podatkowy i sposób ściągania podatków niszczy substancję majątkową. Oczywiście należy sobie uświadamiać, że nie ma takiego systemu podatkowego, któryby komuś istotnie czegoś nie brał. Majątek jest tak szeroko pojmowany przez każdego, że każdy system podatkowy, któryby polegał na tem, żeby substancji majątkowych nigdy w poszczególnych wypadkach nie naruszać, jest to system podatkowy znany bardzo dawno w Polsce, 
Premier Grabski uważał, że podstawą dobrze funkcjonującego państwa jest równowaga budżetowa. „Twarda to konieczność, ale konieczność. Bez równowagi budżetu nie utrzymamy kursu złotego i nie otrzymamy pożyczki zagranicznej. Trzeba wiele poświęcić, ażeby tę równowagę utrzymać" 89 . Nadmiar drukowanych pieniędzy papierowych bez pokrycia, w celu likwidacji deficytu budżetowego prowadzi bowiem do wyniszczenia kraju i zmierza do upadłości. „Gdy państwo raz wejdzie na tę drogę trudno mu z niej zawrócić"90. Istotne jest to, że słowa te napisał w 1919 r., tj. przed falą hiperinflacji w Polsce w 1923 r.

W latach 30. dominował pogląd, że budżet państwa musi być zrównoważony. Równowagę budżetową traktowano jako podstawę stabilizacji gospodarczej i walutowej ${ }^{11}$. Z. Knakiewicz uważa, że w warunkach walki z kryzysem równowaga budżetowa przestaje być gospodarczym kanonem. Jeśli budżet został poważnie zachwiany, to próby mechanicznego osiągnięcia równowagi budżetowej przez zwiększenie opodatkowania lub zmniejszenie wydatków potęgują słabość gospodarcząą

Aktualnie deficyt nie jest traktowany jako zjawisko wyjątkowe. Dopuszcza się możliwość nierównowagi budżetowej, ale do określonych granic. Likwidowanie deficytu „na siłę” może zahamować wzrost gospodarczy. Z drugiej zaś strony, patrząc na kryzys finansowy w ostatnich latach, nadmierne i nagminne luzowanie dyscypliny w dziedzinie finansów publicznych, uświadamiamy sobie, że poglądy Grabskiego w tej kwestii nie są anachroniczne.

Jedynym wyjściem, według Grabskiego, było ograniczenie wydatków państwowych i prowadzenie szerokiej akcji oszczędzania. Rzeczywistość

a polega na tem, aby właściwie podatków wcale nie płacić... To są rzeczy nie do pomyślenia, żadne ogólne zawieszenie poboru podatków, ogólne zrzeczenie się nie jest możliwe, natomiast potrzebny jest postęp i udoskonalenie samego systemu podatkowego. Nad tem udoskonaleniem pracujemy bardzo gorliwie. Sejm ma dużo do zrobienia. W tym roku zreformowaliśmy podatek obrotowy, zgodnie z potrzebami sfer gospodarczych, i podatek dochodowy też w kierunku obniżenia, bo wszędzie szło o obniżkę" (ibidem, s. 28-29).

${ }^{89}$ Ibidem, s. 329.

${ }^{90}$ „Przy spadku wartości pieniądza, tj. przy wzroście drożyzny niemożliwą się staje równowaga budżetowa w gospodarce państwowej. Podatek i dochód wszelki, obliczony w jednym miesiącu, wpływa w innym, gdy już posiada mniejszą wartość i przez to dochód ten staje się niewystarczający. Spadek waluty zagranicą tak samo niweczy równowagę budżetową, gdyż sprowadza drożyznę sprowadzonych produktów większą, niż przewidywana" (W. Grabski, Projekt programu..., s. 15).

${ }^{91}$ Takie stanowisko prezentowali m.in.: A. Krzyżanowski, Polityka i gospodarstwo, Kraków 1931, s. 610-612 oraz W. Zawadzki, Wyktad o polityce finansowej, „Polska Gospodarcza” 1934, z. 19 , s. 575-578.

${ }^{92}$ Z. Knakiewicz, Deflacja polska, Warszawa 1967, s. 244. 
gospodarcza dowiodła słuszności takiego stanowiska. Polityka zaciskania „śruby podatkowej" w latach 1930-1935 nie zwiększyła dochodów budżetowych ${ }^{93}$.

Rząd Grabskiego rozpoczął oszczędzanie od swojego „podwórka”. Zredukował m.in. wydatki reprezentacyjne na wynagrodzenia i zwolnił część personelu. Następne gabinety obniżały, w imię równowagi budżetu, pensje urzędnikom. Grabski krytykował ten sposób oszczędzania. Podkreślał, że racjonalną oszczędność można osiągnąć tylko drogą reorganizacji samej pracy, polegającej na uproszczeniu formalności oraz na zmniejszeniu czynności powtarzających się w działalności poszczególnych instytucji. Odnosiło się to do pracy aparatu władzy, biur prywatnych oraz wielkich przedsiębiorstw.

Stawiał pytanie, czy redukować urzędników? I odpowiadał, że zbędnych już zwolniono. Zalecał walkę z biurokratyzmem. Każdy urzędnik stawiał zbyt dużo wymagań formalnych swoim podwładnym. Należało skończyć z biurokratyzmem centralnym, i to raz na zawsze. Wszyscy narzekali na biurokrację, a wymagania formalne stawiane $z$ góry przez rząd i przez Najwyższą Izbę Kontroli Państwa wciąż rosły. Oszczędności z tego tytułu, a także w innym zakresie, wymagały zmian ustawodawczych. Jednakże Sejm uchylał się od podjęcia decyzji co do tej działalności. Sejm nie rozpatrzył wielu projektów rządowych. Projekt ustawy premiera Grabskiego z 1925 r. o Radzie Oszczędnościowej został odrzucony. W polityce oszczędnościowej bez ofiar obejść się nie można, ale ci, którzy domagają się oszczędności nie chcą sami ponosić ofiar - konkludował W. Grabski ${ }^{94}$.

Jako jedną z metod uzyskania oszczędności proponował likwidowanie całych ogniw i placówek organizacyjnych poprzez ich łączenie. Na przeszkodzie stały jednak partykularne interesy poszczególnych grup społecznych. „Jeśli przyjdzie zmniejszać liczby urzędników, to nie należy czynić tego mechanicznie, jak to dotychczas się odbywało. Trzeba reorganizować system biurowości, zmieniać sposób rządzenia i uwzględniać podział administracyjny kraju. Wówczas można będzie osiągać oszczędności nie tylko na wydatkach personalnych, ale i na rzeczowo-administracyjnych" ${ }^{95}$.

\footnotetext{
${ }^{93}$ Z. Knakiewicz, op.cit., s. 230-231.

${ }^{94}$ W. Grabski, Dwa lata pracy..., s. 329-332.

${ }^{95}$ Ibidem, s. 333.
} 


\section{System pieniężno-kredytowy}

Władysław Grabski był zwolennikiem zdrowej i silnej waluty opartej na złocie. Uważał ją za podstawę rozwoju życia gospodarczego oraz siły finansowej państwa. Zachowanie stabilnego pieniądza jako stałego miernika wartości gospodarczych było warunkiem sanacji ekonomicznej kraju. Nie uważał waluty złotej za „bóstwo”, ale za środek, prowadzący do zamożności obywateli i siły Państwa ${ }^{96}$.

W przemówieniu wygłoszonym w Sejmie 6.10.1925 r. stwierdził: „Dlatego też utrzymanie złotego, opartego na złocie i walutach, dzięki osobnemu statutowi Banku Polskiego, dającemu mu pełną od Rządu niezależność, należy uznać za jeden z kamieni węgielnych programu. Wszelkie pomysły znaków pieniężnych nominalnych $\mathrm{z}$ jakimikolwiek dodatkami w nazwie, jak złoty hipoteczny, czy w innej kombinacji słownej, należy stanowczo odrzucić, jako prowadzące w sposób nieunikniony do inflacji”"97.

Potrzeby odrodzonego państwa polskiego były bardzo duże. Wprawdzie wojna z bolszewikami zakończyła się, ale nadal na armię przeznaczano znaczące środki finansowe. Ponadto budowano nowy aparat państwowy, rozbudowywano infrastrukturę, pieniądze potrzebne były na cele socjalne, oświatę i służbę zdrowia. W tej sytuacji pojawiały się pomysły dodatkowego „pieniądza rządowego" czy asygnat bankowych. Premier temu się przeciwstawia9 ${ }^{98}$. Nie zgadzał się na oparcie polskiego handlu zagranicznego na kontyngentach, ponieważ zmiana ta osłabiłaby złotego i wzmocniła „czarną giełdę"

Oponował przeciwko dewaluacji złotego. Twierdził, że waluta raz zaprowadzona nie może być następnie dopasowywana do chwilowego stanu osłabienia życia gospodarczego w kraju. Dewaluacja stwarza bowiem tylko „pozory nowej siły”. Pieniądz musi być utrzymany na odpowiednim poziomie, aby powrócić z czasem, po poprawie sytuacji gospodarczej, do pełnej wartości ${ }^{100}$.

${ }^{96}$ W. Grabski, Program walki..., s. 15.

${ }^{97}$ Ibidem, s. 42.

${ }^{98}$ Mamy złotego polskiego a życie gospodarcze pragnęłoby jednak obok złotego polskiego mieć jeszcze asygnaty bankowe i asygnaty rządowe. I ludzie łamią sobie głowy nad tym, aby stworzyć nowy surogat pieniądza. Rząd musi się temu oprzeć, bo wszelki surogat pieniądza, wszelki surogat złotego polskiego pod tą lub inną postacią jest sposobem podkopywania siły złotego polskiego, polegającej na tym, że jest on oparty na własnej ustawie, której nikt nie może osłabić ubocznymi działaniami (W. Grabski, Równowaga budżetowa $w$ świetle sytuacji gospodarczej, Warszawa 1924, s. 114).

${ }^{99}$ AAN, Akta Władysława Grabskiego, sygn. 2, k. 46. List do Stanisława z dn. 4.09.1933 r.

${ }^{100}$ W. Grabski, Dwa lata pracy..., s. 266. 
$\mathrm{Na}$ posiedzeniu Narady Gospodarczej 1.10 .1925 r. kategorycznie oświadczył, że podstawą programu naprawczego musi być „wartość gospodarcza stałego miernika pod postacią złotego, zabezpieczonego złotem i walutami”, Przekonywał tych, którzy twierdzili, że złoty już nie jest stałym miernikiem ${ }^{101}$. Mówił: „Najważniejszą więc rzeczą jest zdać sobie sprawę, że nie może być mowy o żadnym programie produkcyjnym i eksportowym, o zdrowym eksporcie, o zdrowym kredycie, o zmniejszeniu stopy kredytowej, o kredytach zagranicznych, przede wszystkiem o kredytach zagranicznych, jeżeliby Polska odwróciła się od waluty, opartej na statucie Banku Polskiego, którego nie można zmienić inaczej, jak tylko za inicjatywą Rady tego Banku, a więc instytucji niezależnej. Więc gdybyśmy się odwrócili od takiej waluty i zaprowadzili znak pieniężny nominalny, a więc nie oparty na stałych podstawach, to wtedy oczywiście cały program musiałby się ukształtować inaczej, zresztą to nie byłby program, tylko rzucenie się na szalony eksperyment, który bardzo krótko mógłby trwać i musiałby się źle skończyć" 102 .

Wśród licznych rad, które zaleciła misja prof. Edwina W. Kemmerera (badała sytuację gospodarczą w Polsce przed udzieleniem pożyczki amerykańskiej) była propozycja wprowadzenia nowego złotego, „równego mniej więcej połowie obecnego". Koncepcję tę Grabski uważał za niepotrzebną ${ }^{103}$. Jego argumentacja była następująca: „Co to nam da za plusy, gdybyśmy oznaczyli, że złoty ma nie «X» złota, a połowę tego. Nic się przez to przecież w życiu gospodarczym nie zmieni, nikt nie będzie taniej produkował, mniej płacił, inaczej spłacał zobowiązania". W jego przekonaniu niski kurs tylko na krótką metę, wprawdzie nie powoduje znacznego wzrostu cen, lecz powoduje spadek wartości pieniądza. Wzrost cen następuje wolniej, ale systematycznie i po pewnym czasie premia eksportowa maleje i wreszcie zanika. Zatem ratować bilans handlowy niskim kursem złotego można tylko chwilowo. Dewaluacja wpłynęłaby na społeczeństwo demoralizująco i stanowiłaby zachętę do nieustannej polityki obniżania wartości własnej waluty. Grabski zwracał uwagę, że „Jeżeli społeczeństwo mało produkuje, a dużo konsumuje, musi mieć zły bilans, musi mieć zanik kapitału i kredytu" ${ }^{104}$. Powołuje się przy tym na pracę Leona

101 „Kto tak twierdzi, myli się. Fakt, że złoty spadł w stosunku do dolara o $15 \%$, nie zmienia stanu rzeczy, że jest stałym miernikiem wartości. Gdyby nie był stałym miernikiem wartości, toby spadł po tych 3-krotnych wzmożonych atakach nie o $15 \%$ w stosunku do dolara, ale znacznie niżej; złoty nie wytrzymałby naporu; gdyby nie był oparty na statucie Banku Polskiego, gdyby to był pieniądz drukowany przez Rząd, gdyby to nie był pieniądz, który ma oparcie o złoto i waluty, to niewątpliwie byłby to spadek nie 15\%-owy w stosunku do dolara, ale katastrofalny" (W. Grabski, Program walki..., s. 15-16).

102 Ibidem, s. 16.

${ }^{103}$ W. Grabski, Czy należy wprowadzać nowego złotego”, „Drogi Naprawy” 1927, nr 1, s. 2-3.

${ }^{104}$ Ibidem, s. 3. 
Barańskiego Uwagi nad obiegiem pieniężnym $w$ Polsce ${ }^{105}$, który wskazał na „rozbieżności między konsumpcją a dochodem narodowym”.

Wzrost kursu złotego w 1927 r. i pozytywne skutki obniżenia kursu dolara uznał Grabski za zwycięstwo swoich racji. Powołując się na informację, zamieszczoną w „Kurierze Warszawskim”, stwierdził z satysfakcją, że pod wpływem obniżenia kursu dolara nastąpił spadek cen zboża na warszawskim rynku zbożowo-towarowym ${ }^{106}$. Wyraził przekonanie, że jeżeli wartość złotego w ciągu kwartału ,podniesie się o 1\% w górę”, to nie zagrozi żadnej gałęzi produkcji. Z czasem złoty odzyska wszystko to, co wcześniej stracił. Powoli powróci do dawnej wartości, tylko nie należy mu w tym przeszkadzać ${ }^{107}$.

W pewnych sferach - pisał W. Grabski - pojawiła się krytyka rządu za to, że nie ratuje kursu dolara. Jej wyrazicielem stał się m.in. „Nasz Przegląd”. Zarzucano sprawującym władzę, że powróciła „grabarszczyzna” ${ }^{108}$.

Jakimi argumentami posługiwali się oponenci W. Grabskiego? Powoływali się przede wszystkim na autorytet prof. E. Kemmerera oraz wskazywali na większe szanse uzyskania kredytów w Stanach Zjednoczonych po przeprowadzeniu dewaluacji złotego. Grabski jednak przestrzegał, że wówczas dolar będzie „królował” w polskiej gospodarce i życiu publicznym. Natomiast złoty stopniowo będzie tracił wartość i stanie się „kopciuszkiem” wobec dolara. W rezultacie losy naszej gospodarki mogą znaleźć się w obcych rękach. Jeśli dopuścimy do obniżenia kursu złotego, suwerenność Polski może być zagrożona $^{109}$.

Odmienne poglądy głosili przedstawiciele Szkoły Krakowskiej. Głównym jej reprezentantem był Adam Krzyżanowski. Szkoła Krakowska zalecała porzucenie waluty złotej, proponując ,zawieszenie wymienialności banknotów złotowych z czasową przejściową przemianą długów obcowalutowych na długi w złotych" ${ }^{110}$. Propozycje odejścia od waluty złotej uzasadniano następującymi argumentami:

1) Waluta złota przestała być walutą międzynarodową i instrumentem kredytu międzynarodowego oraz handlu światowego.

2) Gold standard przestał pełnić rolę instrumentu kapitalizacji.

${ }^{105}$ L. Barański, Uwagi nad obiegiem pieniężnym w Polsce, Warszawa 1926.

106 „Kurier Warszawski”, 1.02.1927, s. 13.

107 W. Grabski, Czego nas uczy zwyżka złotego?, „Drogi Naprawy” 1928, nr 2, s. 3.

108 Termin „grabarszczyzna” został ukuty jesienią 1925 r. w czasie zmagań opozycji w walce z Grabskim. Oznaczał on politykę walutową, mającą na celu podniesienie wartości złotego. Senator Rotenstreich z Klubu Żydowskiego posłużył się tym określeniem, aby bronić kursu dolara (ibidem). ${ }^{109}$ Ibidem, s. 2-3.

${ }^{110}$ A. Krzyżanowski, Dolar i złoty, Kraków 1936, s. 231. 
3) Polska, nie mając aktywnego salda bilansu handlowego, nie miała realnych możliwości ponoszenia dalszych ciężarów z tytułu premii eksportowych ${ }^{111}$.

Faktycznie - w okresie 1931-1937 - wśród 64 państw o samodzielnej walucie, 36 zawiesiło wymienialność na złoto, a 33 zastosowały ograniczenia dewizowe. W tej sytuacji w handlu międzynarodowym upowszechniły się rozliczenia clearingowe $^{112}$. Należy jednak pamiętać, że wypowiedzi W. Grabskiego $\mathrm{w}$ tej kwestii pochodzą z lat 20., natomiast ekonomistów krakowskich $-\mathrm{z}$ lat 30 .

A. Krzyżanowski opowiadał się za wprowadzeniem dewaluacji bez inflacji. Powoływał się przy tym na pozytywne w tej kwestii doświadczenia angielskie. Likwidacja polityki deflacyjnej za pomocą inflacji groziła - jego zdaniem „Zabagnieniem naszej sytuacji budżetowej i finansowej”113.

Dewaluacja, jako jednorazowy akt obniżenia relacji złotego do złota, nie prowadziłaby jeszcze do niekontrolowanej inflacji. Zwiększenie emisji pieniądza mogłoby wpłynąć na wzrost inwestycji, co w efekcie - poprzez mechanizmy mnożnikowe - przyspieszyłoby produkcję nie tylko w branżach wytwarzających bezpośrednio na rzecz inwestycji, lecz także w przemysłach konsumpcyjnych twierdzą Z. Landau i J. Tomaszewski ${ }^{114}$.

Autorka klasycznej pracy o polskiej deflacji, Zenobia Knakiewicz, wyraziła przekonanie, że program dewaluacji bez inflacji był lepszym wariantem umożliwiającym przystosowanie się do kryzysu niż polityka deflacji ${ }^{115}$. Nie należy też wykluczyć, iż w trakcie jego stosowania doszłoby do „normalnej” dewaluacji, która spowodowałaby umiarkowaną inflację, tj. zjawisko korzystne w walce z kryzysem ekonomicznym.

Następcy premiera Grabskiego bronili skutecznie, w latach 30., mocnej pozycji złotego. W sytuacji, kiedy inne państwa stosowały umiarkowaną inflację, gospodarka polska poniosła znaczące straty.

W świetle przedstawionych faktów można śmiało zaliczyć W. Grabskiego do zwolenników teorii ilościowej pieniądza, których w dzisiejszym języku ekonomicznym określa się mianem monetarystów ${ }^{116}$.

111 A. Krzyżanowski, Trzy systemy polityki walutowej, „Przegląd Gospodarczy” 1932, z. 14, s. $572-573$.

112 Z. Landau, J. Tomaszewski, Lata interwencjonizmu państwowego, 1936-1939, Warszawa 1989, s. 464; T. Łychowski, Rozwój systemów clearingowych, „Polska Gospodarcza” 1938, nr 4, s. $119-122$.

${ }^{113}$ A. Krzyżanowski, Dolar i złoty..., s. 231.

${ }^{114}$ Z. Landau, J. Tomaszewski, op.cit., s. 340.

115 Z. Knakiewicz, op.cit., s. 99-100.

${ }^{116}$ T. Gruszecki, Reforma pieniężna W. Grabskiego. Ile warta jest stabilizacja pieniadza?, [w:] Wtadystaw Grabski. Uczony i mąż stanu, Lublin 2005, s. 147. 


\section{Cykle koniunkturalne. Kryzysy ekonomiczne}

Władysław Grabski przeprowadził wnikliwe rozważania nad koniunkturą gospodarczą, powodowany głównie dążeniem do wyjaśnienia natury kryzysów ekonomicznych, w szczególności - kryzysów w rolnictwie. Teoria miała umożliwić podjęcie działań praktycznych, które zapobiegałyby ustawicznym kryzysom w rolnictwie światowym. Polska, kraj rolniczo-przemysłowy, była tym szczególnie zainteresowana.

W. Grabski podkreślał z uznaniem, że badania nad koniunkturą uzyskały status nauki. Definiował koniunkturę gospodarczą, jako ustawiczny ruch, który cechuje się pewną regularnością wahań. Wahania cykliczne nazywał, jak współcześni ekonomiści, cyklem koniunkturalnym ${ }^{117}$.

Koniunkturę kształtowały dwa czynniki: zewnętrzny i wewnętrzny. Do czynników zewnętrznych zaliczał: zmienność sił natury, zasoby surowcowe i stosunki między poszczególnymi państwami; do wewnętrznych zaś (uznawał je za główny czynnik sprawczy): energię wytwórczą społeczeństwa, wynalazki oraz dążenia jednostek do kształtowania własnego bytu ${ }^{118}$. Właściwości umysłu ludzkiego i psychiki uznawał za główną przyczynę falowania w działalności gospodarczej: „Zmienność optymizmu i pesymizmu, zmienność przeceniania sytuacji i niedoceniania, zmienność okresu wytężenia wszystkich sił, by jak najwięcej produkować i się bogacić, oraz okresów zniechęcenia, by zaledwie utrzymać się na powierzchni życia - jest to naturalne falowanie życia gospodarczego" 119 .

Zmienne stany psychiki ludzkiej oddziałują na cykle koniunkturalne. Trzy czynniki - według Grabskiego - kształtują falowanie życia gospodarczego: duch spekulacji, obrót środkami pieniężnymi i „napięcia” produkcji towarowej. Czynnikiem utrzymującym pozostałe $\mathrm{w}$ stanie ciągłego falowania jest duch spekulacji, będący motorem kolejnych faz cyklu koniunkturalnego. Grabski wyjaśniał, że jest to zwykła skłonność natury ludzkiej, aby kierować się własnym interesem. Pobudza ona do szukania najkorzystniejszej lokaty wśród tych, którzy dysponują większymi sumami pieniędzy. Spekuluje ten, kto obraca pieniędzmi, szukając dla nich jak największego zysku. Cykl koniunkturalny i spekulacja są wytworami ustroju kapitalistycznego ${ }^{120}$.

${ }^{117}$ W. Grabski, Koniunktura, kryzysy i rozwój gospodarczy, Warszawa 1929, s. 4.

${ }^{118}$ W. Grabski uważał, że wpływ jednostek w sferze stosunków gospodarczych ma mniejsze znaczenie niż w polityce, gdzie jest niezaprzeczalny (ibidem, s. 18).

${ }^{119}$ Ibidem, s. 6.

${ }^{120}$ Ibidem, s. 13. 
Spekulacja kapitałem „ruchomym” prowadzi do kryzysu ekonomicznego. Nauka o cyklach koniunkturalnych wnosi do teorii kryzysów nowy element ${ }^{121}$. Oto, jak W. Grabski przedstawiał mechanizm cyklu koniunkturalnego: „Gdy produkcja jest w stanie depresji i pieniądz nie znajduje pola dla swego działania w dziedzinie pracy wytwórczej, spekulacja, korzystając ze stanu ogólnej depresji, pierwsza staje się fermentem ożywienia interesów, co wywołuje to, że depresja przechodzi $\mathrm{w}$ stan polepszenia. Wtedy to ożywia się produkcja i pieniądz znajduje zastosowanie $\mathrm{w}$ większych obrotach po wyższej stopie procentowej, ale mimo to spekulacja dalej trwa, aż stan dochodzi do okresu pomyślności, w którym choć produkcja i obroty pieniężne wzrastają, ale spekulacja się zatrzymuje, bo cała energia gospodarcza idzie w kierunku produkcji. Stwarza to okres napięcia finansowego, który poprzedza kryzys. W stanie napięcia akcje giełdowe spadają, bo kapitał został całkiem pochłonięty przez ruch towarowy. Ale ruch ten dochodzi do maximum i ruch zwyżkowy cen zostaje $z$ kolei zatrzymany. Takie zatrzymanie się cen towarów z okresu napięcia jest znakiem zwrotnym dla procesu odmiennego od tego, który miał miejsce w ciągu całego okresu polepszania się i pomyślności. Wtedy wzrastające ceny zachęcały do wkładania pieniędzy w produkcję. Teraz odwrotnie, produkowanie przestaje się opłacać. Po danych cenach trudno znaleźć nabywców. Ilość towarów się nagromadza bez zbytu. To doprowadza do kryzysu. W okresie kryzysu ceny spadają. Producenci potrzebują pieniędzy, by utrzymać swoje warsztaty, a więc wycofują swoje wkłady i sprzedają akcje, które spadają do najniższego poziomu, wkłady się zmniejszają, stopa procentowa rośnie silnie. Po szeregu bankructw kryzys sam przez się ustępuje i nastaje uregulowanie się stosunków, które przechodzą w stan depresji o niskich cenach, małej produkcji i niskiej stopie procentowej. W tym stanie rzeczy znów duch spekulacji znajduje podłoże, by wywoływać nowe ożywienie interesów" $" 122$.

W. Grabski zapoznał się z różnymi teoriami cykli koniunkturalnych. Nie podaje jednak nazwisk badaczy. Ogranicza się tylko do stwierdzenia: ,jak wykazały badania". Pisze, że fale (cykle) mogą być długie lub krótkie. Czas trwania fali może wynosić 7-8, 10-20, 50-100, 100-200 lat ${ }^{123}$. Jest przekonany, że cykle koniunkturalne stanowią właściwość gospodarki rynkowej. Wysuwał jednak zaskakującą sugestię, stwierdzając, że falowanie w gospodarce występowało jeszcze przed ustrojem kapitalistycznym. W uzasadnieniu wyjaśniał, że

\footnotetext{
${ }^{121}$ Ibidem, s. 6-7.

122 Ibidem, s. 7.

${ }^{123}$ W. Grabski, Polityka ekonomiczna ..., s. 15.
} 
rynek funkcjonował już w starożytności i średniowieczu ${ }^{124}$. Pogląd ten pozostaje W wyraźnej sprzeczności z teorią ekonomii ${ }^{125}$.

W gruncie rzeczy Grabski przyjmował, jeśli chodzi o długość trwania fal (7-8 lat), cykl klasyczny, w którym występują cztery fazy: kryzys, depresja, ożywienie, rozkwit. Jest on najbardziej zbliżony do cyklu Juglara (nazwa pochodzi od nazwiska francuskiego ekonomisty Clementa Juglara), który określił przeciętną długość trwania cyklu na 8-10 lat. J. A. Estey wyróżnia również cztery fazy, inaczej je nazywając, a mianowicie: prosperity, recesja, depresja i ożywienie ${ }^{126}$.

Rozróżniał dwie zasadnicze fazy: ruch w górę i w dół, które następnie dzielił na dalsze odcinki. Ożywienie i napięcie (rozkwit) są to fazy ruchu w górę, kryzys i recesja (depresja) są ruchem w dół. Stwierdzał, że współczesna nauka badania koniunktur wyróżnia dwie zasadnicze tendencje: ożywienie i depresję ${ }^{127}$.

W. Grabski zwracał baczną uwagę na fale przejściowe, a mianowicie w okresie ożywienia wyróżniał falę polepszenia i pomyślności, a po kryzysie recesję i depresję. W tych krótszych okresach możliwe było podjęcie środków zaradczych. Wyrażał przekonanie, że w ruchu cyklicznym może nie wystąpić, w pewnych wypadkach, okres napięcia (rozkwitu) i kryzysu, zawsze jednak musi być faza ożywienia i depresji ${ }^{128}$.

W zależności od rodzaju czynników cykl koniunkturalny mógł mieć różny przebieg. Może się zdarzyć, że po ożywieniu pomyślności dochodzi, z pominięciem kryzysu, do recesji i depresji. Jeżeli odcinki depresji początkowej (przed ożywieniem) i końcowej (po recesji) znajdują się na jednym poziomie, to ruch koniunktury nie przynosi gospodarce żadnych korzyści. Natomiast, kiedy okres recesji jest krótszy od ożywienia i depresja końcowa jest na poziomie wyższym od początkowej, wówczas pojawia się szereg fal o tendencji zwyżkowej $^{129}$.

124 „Następowanie po sobie faz ożywienia i depresji jest to objaw zasadniczy i naturalny w życiu gospodarczem każdego czasu i u wszystkich społeczeństw. Niektórzy uważają, że jest to właściwość jedynie ustroju kapitalistycznego, że w gospodarstwach przedkapitalistycznych nie było pola do tego. U podstawy tętna życia gospodarczego leży pewien stopień ruchliwości gospodarczej, wywołany orientowaniem procesów gospodarczych podług potrzeb rynku. A więc wtedy, gdy potrzeby rynku odgrywały mniejszą rolę, wtedy i te kolejne fazy tętna życia gospodarczego mniej ostro występowały. Ale kiedyż życie gospodarcze było niezależne od rynku? Przecież w wiekach średnich nie wszystko robiono tylko na obstalunek, nie mówiąc o starożytności z dużym handlem wymiennym (W. Grabski, Koniunktura, kryzysy..., s. 5).

125 J. A. Estey, Cykle koniunkturalne, Warszawa 1959, s. 48.

${ }^{126}$ Ibidem, s. 75.

${ }^{127}$ W. Grabski, Polityka ekonomiczna..., s. 13-14.

${ }^{128}$ Ibidem, s. 15.

${ }^{129}$ Ibidem, s. 14. 
W. Grabski doceniał badania koniunktury, ponieważ pozwalały wyciągać wnioski na przyszłość. Sporządzenie prognozy jednak nie jest, jego zdaniem, łatwe, gdyż związek między fazami a wskaźnikami makroekonomicznymi jest dość luźny i w znacznym stopniu zależny od zmiennych zachowań rynku ${ }^{130}$.

Rys. 1. Całkowity przebieg fali koniunktury

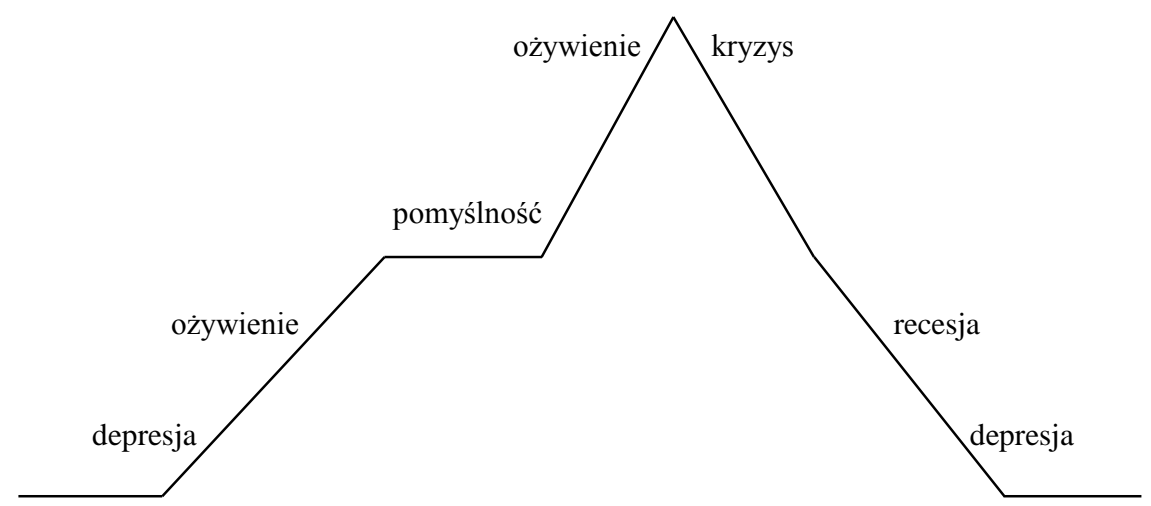

Źródło: W. Grabski, Polityka ekonomiczna..., s. 14.

Samo zrozumienie rozwoju życia gospodarczego i przebiegu koniunktur wymaga szerokich horyzontów historycznych i społecznych. W pełni wiarygodna prognoza nie jest możliwa, ponieważ ewolucja stosunków ekonomicznych, a więc i przebieg cyklu koniunkturalnego, stanowią wynik działania skomplikowanych czynników gospodarczych, społecznych, politycznych, przypadku (klęski losowe, wynalazki przypadkowe) oraz roli jednostek ${ }^{131}$.

Nawet jeżeli taka prognoza jest nierealna, to już cennym wynikiem badań w tym zakresie będzie zorientowanie się co do kierunku przyszłych zmian w gospodarce. Różni się tym od prognozy, że „nie mówi, co nastąpić musi, ale wskazuje na to, na co się zanosi, co staje się prawdopodobne. Więcej od nauk poświęconych przejawom działalności ludzkiej, wymagać nie można" przekonuje W. Grabski ${ }^{132}$.

We współczesnej gospodarce podejmowane są próby korelacji cykli koniunkturalnych w poszczególnych krajach. Poszukiwanie zbieżności ma na

\footnotetext{
${ }^{130}$ Ibidem, s. 15.

${ }^{131}$ W. Grabski, Koniunktura, kryzysy..., s. 22.

132 Ibidem, s. 23.
} 
celu neutralizację przyczyn powstawania wstrząsów gospodarczych. Mimo stosowania nowych metod i technik badawczych zwalczanie szoków ekonomicznych jest nadal mało skuteczne ${ }^{133}$.

Po I wojnie światowej zaczęły powstawać instytuty poświęcone badaniom koniunktury. Pionierami byli Amerykanie. Cały szereg takich instytucji utworzono w Stanach Zjednoczonych. W. Grabski podkreślał, że praca ludzi nauki przyniosła pierwsze pozytywne wyniki. W 1919 r. Instytut Howarda przewidział kryzys w 1920 r. Badania koniunktur zaczęły rozwijać się również w Europie. W 1926 r. instytut do badań kryzysów i koniunktury zorganizowano w Berlinie, a w 1928 r. - w Warszawie. Instytuty i placówki naukowe o licznym personelu zastąpiły prace gabinetowe ${ }^{134}$.

Badania nad koniunkturą należało prowadzić ostrożnie, ale były - w jego przekonaniu - znaczne możliwości, aby umożliwić człowiekowi wpływ na kształtowanie się poszczególnych faz koniunktury, a nawet uniknięcie kryzysu. Grabski pisze, w jaki sposób można uniknąć kryzysu bądź go złagodzić: „badania konjunktury otworzyły nowe horyzonty dla zagadnienia walki z kryzysami, jakkolwiek bowiem wyświetliły one, że kryzys jest nieodłączną fazą cyklu konjunkturalnego, ale, wskazawszy na główny motor zmienności tych faz, rzuciły światło na zagadnienie zasadnicze, jaką drogą najłatwiej wywrzeć wpływ na ich przebieg. Jeżeli bowiem fazy konjunktury następują po sobie w wyniku oddziaływania ruchu spekulacyjnego kapitału ruchomego, przerzucającego się z rynku walorów do produkcji towarów i do kredytów pieniężnych, to jasnem jest, że nie tylko kartele i trusty, ale i wszystko to, co reguluje obieg pieniężny i kredyt, a przez to przypływ i odpływ kapitału ruchomego tu i tam, wszystko to staje się czynnikiem, który bez zmian w zasadzie samej ustroju kapitalistycznego może wpłynąć na to, by bądź wybuch kryzysu oddalić na dalszą metę, bądź utrzymać go w charakterze możliwie bezbolesnym, bądź może całkowicie go uchylić"135.

133 J. Czaja, Zmiany cykli koniunkturalnych w Unii Europejskiej oraz ich konsekwencje dla gospodarek krajów członkowskich, [w:] Polityka ekonomiczna. Współczesne wyzwania, red. M. Klamut, Warszawa 2007, s. 72 i 75.

${ }^{134}$ „W dziedzinie nauk ekonomicznych badanie konjunktury stało się poważną próbą i polem doświadczalnem szerokiego stosowania współpracy naukowej o charakterze laboratoryjnym. Dotychczas praca ekonomistów była to praca pojedyńczych uczonych, praca ściśle gabinetowa. Wydawnictwa encyklopedyj i podręczników, wymagające współpracy wielu uczonych, nie wykraczały z tej metody pracy, gdyż tworzyły zbiór prac gabinetowych poszczególnych uczonych. Pracę naukową, zorganizowaną na wzór laboratorjum, widzimy w instytutach i biurach badania konjunktur" (W. Grabski, Polityka ekonomiczna ..., s. 11).

${ }^{135}$ Ibidem, s. 10. 
Kryzysowi amerykańskiemu z 1920 r., który został przewidziany dzięki badaniom koniunktury, udało się zapobiec właśnie poprzez zastosowanie systemu oddziaływania na kapitał obrotowy i na obrót pieniężny (celowa działalność banków emisyjnych).

W. Grabski, analizując sytuację gospodarczą w Stanach Zjednoczonych i Niemczech, dostrzegł już w 1927 r. narastające przesłanki Wielkiego Kryzysu Gospodarczego, zwłaszcza obserwując widoczny stan napięcia gospodarczo-finansowego. Uważał, że jeśli kryzys wybuchnie w tych krajach w 1928 r., mimo działalności zapobiegawczej banków emisyjnych, będzie to potwierdzenie poglądu, że kryzysy są nieodłączną częścią cyklu koniunkturalnego ${ }^{136}$. W liście do brata Stanisława z 24.04.1928 r. zgadza się z nim, że kapitalizm znalazł się w fazie kryzysu ${ }^{137}$.

W opracowaniach Grabskiego nie spotykamy propozycji dotyczących rozwoju interwencjonizmu państwowego. Opowiadał się przede wszystkim za utrzymaniem stabilnego pieniądza, selektywnej polityki inwestycyjnej, ograniczenia konsumpcji i oszczędzania. Był zatem zdecydowanie bliżej teorii Friedricha von Hayeka niż Johna M. Keynesa ${ }^{138}$.

Poglądy W. Grabskiego dotyczące cyklów koniunkturalnych są nadal aktualne. Podstawą ich wiarygodności było uwzględnianie realiów życia gospodarczego. Dane statystyczne uzupełniane są w pracach Grabskiego obserwacjami rytmu przyrody oraz przewidywaniem skutków, wynikających z zachowań ludzkich. W jego rozważaniach odnajdujemy elementy znanych teorii cyklów koniunkturalnych, m.in. teorii monetarnej, teorii innowacji i teorii psychologicznej ${ }^{139}$.

W literaturze przedmiotu problematyka cykli koniunkturalnych znalazła głęboki rezonans ${ }^{140}$. Autorem monumentalnego dzieła: Cykle koniunkturalne jest James Arthur Estey ${ }^{141}$. Pozostając $\mathrm{z}$ całym szacunkiem do profesjonalizmu J. A. Esteya uważam, że poglądy W. Grabskiego dotyczące czynników kształtowania koniunktury gospodarczej, były bardziej realistyczne. Łączył on bowiem

${ }^{136}$ W. Grabski, Koniunktura, kryzysy..., s. $12-13$.

${ }^{137}$ AAN, Akta Władysława Grabskiego, sygn. 2, k. 9. List do Stanisława z dn. 24.04.1928 r.

138 J. Godłów-Legiędź, Doktryna społeczno-ekonomiczna Friedricha von Hayeka, Warszawa 1992, s. 146-150.

${ }^{139}$ Zob. M. Friedman, Monetary Studies of the National Bureau, [w:] idem, The Optimum Quantity of Money and Other Essays, Chicago 1969, s. 271-275; A. C. Pigou, Industrial Fluctuations, London 1913; J. A. Schumpeter, Business Cycles, New York 1939.

${ }^{140}$ A. H. Hansen, Business Cycles Theory, Boston 1927; W.C. Mitchell, Bussiness Cycles, The Problem and Its Setting, New York 1927; J. M. Keynes, Treatise on Money, t. I, New York 1930; W. L. Thorp, Business Annals, New York 1926.

${ }^{141}$ J. A. Estey, op.cit., s. 101 i 208. 
przyczyny przyrodnicze, ekonomiczne i psychologiczne w jeden mechanizm, uruchamiający cykl koniunkturalny. Dzisiejsza rzeczywistość potwierdza, jak trafny był zwłaszcza pogląd wskazujący, że motorem napędzającym cykle jest „duch” spekulacji kapitałem „ruchomym”.

Badania koniunktury spowodowały postęp nauki o kryzysach. Wzbogaciły wiedzę o przyczynach i czynnikach kształtujących koniunkturę gospodarczą. Umożliwiły poznanie zwłaszcza jednego z nich, poprzednio niedocenianego ducha spekulacji pieniężnej i kredytowej. W. Grabski twierdził, że otworzyło to możliwość zażegnania kryzysów, oddalenia momentu ich wybuchu bądź osłabienia ich przebiegu. Aby osiągnąć ten cel, trzeba przeprowadzić akcję banków emisyjnych skoordynowaną z działalnością poszczególnych rządów i społeczeństw. Gdyby się to udało, „byłoby to wielką zdobyczą ludzkości o doniosłości wprost nieocenionej. Dałoby to jednocześnie podstawy dla dyktatury banków emisyjnych - dyktatury, która mogłaby stać się nowym czynnikiem całej polityki międzynarodowej" ${ }^{142}$. Konkluzją tą potwierdził jeszcze raz, że jest monetarystą.

Najwięcej miejsca w twórczości W. Grabskiego, jak już wcześniej nadmieniłem, zajmowała problematyka dotycząca kryzysów, a w szczególności kryzysów w rolnictwie.

W. Grabski rozpoczął analizę od przedstawienia pojęcia kryzysu: „Kryzysem w dziedzinie życia gospodarczego nazywamy stan, przy którym produkty towarowe tracą swoją poprzednio nabytą realną zdolność nabywczą do tego stopnia, że uzyskiwane ceny nie pokrywają kosztów produkcji i nie dają producentowi ekwiwalentów, umożliwiających mu kontynuowanie procesów wytwórczych w poprzednio ustalonej skali’"143.

$\mathrm{Z}$ definicją tą nie można się zgodzić, ponieważ ludność, a nie produkty towarowe, traci „realną zdolność nabywczą”. W innych opracowaniach nie podtrzymywał tej definicji. Pisał wyraźnie, że kryzys w ustroju kapitalistycznym jest objawem nadprodukcji. Tempo wzrostu produkcji przekraczało bowiem zapotrzebowanie społeczeństwa. W rezultacie coraz więcej wyprodukowanych wyrobów zalegało w magazynach. Nadmiar podaży w stosunku do popytu oznaczał kryzys ekonomiczny ${ }^{144}$. Takie rozumienie kryzysu jest zgodne $\mathrm{z}$ teorią współczesnej ekonomii, która stoi na stanowisku, że cykle gospodarcze (w tym i kryzysy) są wywoływane, w przeważającej mierze, zmianami globalnego popytu $^{145}$.

\footnotetext{
${ }^{142}$ W. Grabski, Koniunktura, kryzysy..., s. 12-13.

${ }^{143}$ W. Grabski, Kryzysy rolnicze światowe i kryzys w Polsce, Warszawa 1930, s. 5.

${ }^{144}$ W. Grabski, Polityka ekonomiczna ..., s. 17; idem, Kryzysy rolnicze ..., s. 4, 7.

${ }^{145}$ P. A. Samuelson, W. D. Nordhaus, op.cit., s. 301.
} 
W. Grabski wyróżniał kilka rodzajów kryzysu. Za najbardziej typowe uznawał kryzysy przemysłowy i rolniczy. Ponadto wymieniał jeszcze kryzysy: giełdowy, kredytowy, bankowy i walutowy. Jeśli kryzys występuje jednocześnie w rolnictwie, przemyśle i wymienionych dziedzinach życia gospodarczego, to wówczas mamy kryzys ogólny. W sytuacji, gdy kryzys dotyka nie tylko wielu dziedzin, ale i wielu krajów, mamy do czynienia z kryzysem powszechnym. Większą skłonność do załamań wykazywały kraje, w których zaznaczał się silny rozwój, występował większy ,pęd do bogacenia się" i wzmagała się spekulacja. Jednym słowem wszędzie tam, gdzie funkcjonowała w pełni gospodarka rynkowa ${ }^{146}$.

W. Grabski bardzo zwięźle charakteryzował poszczególne kryzysy i całą uwagę skupiał na kryzysach rolniczych. Pisał, że kryzysy przemysłowe są stosunkowo częstymi objawami życia gospodarczego i powtarzają się co siedem lat (duże uproszczenie). Cechuje je wysokie bezrobocie i duża liczba „zrujnowanych” zakładów przemysłowych. Zazwyczaj towarzyszą im kryzysy handlowe, które są tylko następstwem przemysłowych. Za najbardziej narażone na kryzys uznawał branżę tekstylną i metalową ${ }^{147}$.

Oto dalszy ciąg charakterystyki prezentowanej przez W. Grabskiego. Kryzysy giełdowe rozpoczęły się od czasów powstania giełdy. Kryzys giełdowy i towarzyszący mu tzw. krach przenosi się natychmiast na inne giełdy, co oddziaływuje silnie na całe życie gospodarcze. Ze względu na wrażliwość na nastroje społeczeństwa i zjawiska gospodarcze, giełda i kryzys giełdowy stanowią barometr rynków i całego życia ekonomicznego. Z kryzysem giełdowym często związany jest kryzys kredytowy. Występuje on wówczas, gdy operacje giełdowe odgrywają bardzo dużą rolę w życiu gospodarczym, np. w Stanach Zjednoczonych.

Kryzys bankowy pojawiał się w wyniku nacisku na banki. Żądanie natychmiastowej wypłaty większych kapitałów, pod wpływem silnych wstrząsów w gospodarce, prowadziło często do upadłości banków.

Kryzys walutowy jest, jak twierdził Grabski, załamaniem się kursu waluty. Kurs ten jest regulowany przeważnie stosunkiem waluty do złota. W wypadku braku zaufania do danej waluty, następuje wzmożona wymiana banknotów na złoto. W Polsce wskaźnikiem zaufania do waluty jest jej wymienialność na obcą, pełnowartościową walutę. Jeśli zapasy złota $\mathrm{w}$ banku centralnym są niedostateczne, przy zwiększonym popycie na obcą walutę kurs własnej może się załamać. Regulatorem kursu walutowego jest państwowy bank emisyjny, a w następnej

\footnotetext{
${ }^{146}$ W. Grabski, Polityka ekonomiczna ..., s. 17.

${ }^{147}$ Ibidem.
} 
kolejności dopiero banki prywatne. W czasie kryzysu walutowego państwo dąży do posiadania możliwie jak największej rezerwy obcych walut, które mają być oparciem dla własnej waluty ${ }^{148}$.

W. Grabski twierdził, że zasadnicze przyczyny kryzysów w przemyśle i rolnictwie są takie same. O jednej z nich była mowa już wcześniej. Chodzi mianowicie o spadek globalnego popytu. Ciągła chęć osiągnięcia coraz większego zysku prowadziła do nadmiernego wzrostu produkcji, która dochodziła do takiego stopnia, że przekraczała znacznie zdolność nabywczą społeczeństwa. Zmniejszenie konsumpcji może też być wynikiem zaburzeń natury kredytowej, społecznej i politycznej. Druga przyczyna związana jest ze sferą kredytowo-pieniężną i wzmagającą się, w wyniku jej funkcjonowania, spekulacją kapitałem obrotowym ${ }^{149}$. Zasadnicze znaczenie w tym zakresie odgrywają zmiany wartości nabywczej pieniądza. „Gdy pieniądz drożeje, to gospodarka pieniężna towarów doznaje kryzysu. Gdy pieniądz tanieje, gospodarka ta doznaje zasadniczo podniety, która nie chroni jednak od kryzysów częściowych, gdyż drożenie towarów nie odbywa się równomiernie i te grupy wytwórczości, w których proces drożenia jest bądź powolniejszy od innych, bądź sztucznie wstrzymywany drogą reglamentacji i utrudnień wywozowych, doznaje kryzysu" - dowodził W. Grabski ${ }^{150}$.

W. Grabski, który przestudiował Kapitał Karola Marksa, zwracał uwagę, że istnieje druga szkoła teorii kryzysów. Według niej, kryzysy są piętnem ustroju kapitalistycznego. Ich przyczyna tkwi przede wszystkim w tym, że robotnik nie otrzymuje pełnego wynagrodzenia za swoją pracę. $Z$ tego powodu rosnąca produkcja, stymulowana przez bogacących się kapitalistów, nie znajduje dostatecznego rynku wewnętrznej konsumpcji. Stan ten musi doprowadzić do kryzysu, który pociąga za sobą liczne ofiary. Według tej teorii, kryzys nie jest regulatorem doprowadzającym rynek do normy, a tylko przejawem smutnej rzeczywistości, ,odkrywającym zło, tkwiące w samym ustroju gospodarki kapitalistycznej" $"$.

W. Grabski konstatuje, że ten pogląd nie wytrzymuje rzeczowej krytyki. Stwierdza, że gdyby każdy pracownik otrzymywał równowartość swej pracy, to nastąpiłby okres stagnacji w gospodarce. Praca człowieka musi bowiem pokryć nie tylko jego utrzymanie, lecz także koszty fabryki, maszyn, narzędzi, ulepszeń, nowych warsztatów itp. ${ }^{152}$

148 Ibidem, s. 18.

${ }^{149}$ Uzależnienie całego systemu rynkowego od ruchu kapitałów pieniężnych oraz spekulacja na rynku prowadzą do zaburzeń w produkcji i konsumpcji - pogląd S. Grabskiego (op.cit., cz. V, s. 114).

${ }^{150}$ W. Grabski, Kryzysy rolnicze..., s. 4, 5 i 8.

${ }^{151}$ Ibidem, s. 8.

${ }^{152}$ W. Grabski, Polityka ekonomiczna ..., s. 17. 
Stanisław, brat Władysława, dowodził, że twierdzenie Marksa, że zysk przedsiębiorcy ,pochodzi jedynie z nadwartości pracy robotników, znalazło tylko uznanie w środowisku socjalistów"153.

W. Grabski wyraził opinię, że w „obecnej” nauce o koniunkturze rolnictwo zostało włączone do ogólnych faz koniunktury. Między kryzysem rolniczym i przemysłowym występuje zależność. Rolnik jest poważnym odbiorcą produktów przemysłowych, a z drugiej strony, przemysł (ludność miast) konsumuje wytworzone przez rolnictwo artykuły żywnościowe. Dawniej koniunktura w rolnictwie stanowiła, w jego przekonaniu, odrębną całość ze względu na odmienne czynniki, wpływające na bieg gospodarki rolnej ${ }^{154}$.

Zdaniem Grabskiego, kryzys w rolnictwie powoduje znacznie więcej czynników niż w przemyśle. Dużo większą rolę odgrywają siły przyrody. W rolnictwie procesy życia biologicznego są ściśle zależne od zmiennych warunków atmosferycznych, chorób roślin i zwierząt oraz klęsk żywiołowych (epidemie, powodzie, szarańcze). Rezultaty produkcji rolniczej ulegają nieustannym wahaniom niezależnym od działań człowieka ${ }^{155}$.

Ze względu na naturę rolnictwa odmiennie układa się w przemyśle i rolnictwie stosunek człowieka do jego warsztatu pracy: „W tym ostatnim warsztat jest czynnikiem czysto objektywnym, jest środkiem jedynie służącym do osiągnięcia towaru. Tymczasem $\mathrm{w}$ rolnictwie rola nie jest dla producenta jedynie warsztatem dla osiągnięcia dóbr materjalnych. Dla ogromnej masy wytwórców drobnych rola jest jednocześnie karmicielką, pracującą na człowieka. Pomiędzy rolą, inwentarzem i człowiekiem odbywa się w drobnym warsztacie rolnym proces symbiozy. Część produktów idzie na sprzedaż, duża ich ilość służy dla spożycia. Warunki produkcji na ogół mogą być dla rolnictwa niekorzystne, ale $\mathrm{z}$ tego nie wynika by warsztat jego pracy miał być porzucony" 156 .

W związku z tym, główna przyczyna kryzysu powszechnego (spadek popytu) odgrywa znacznie mniejszą rolę $\mathrm{w}$ uruchomieniu kryzysu w rolnictwie. Wielość czynników wpływa też na częstotliwość, charakter i czas trwania kryzysu w gospodarce rolnej.

W. Grabski wyrażał pogląd, że kryzys w rolnictwie powoduje kurczenie się rynku dla produkcji przemysłowej, wzmaga bezrobocie i pogłębia kryzys gospodarczy. Z drugiej strony sytuacja krytyczna w rolnictwie zaostrza „ogólny

\footnotetext{
${ }^{153}$ S. Grabski, op.cit., cz. VI, s. 6.

${ }^{154}$ W. Grabski, Polityka ekonomiczna ..., s. 19.

${ }^{155}$ W. Grabski, Kryzys rolniczy, Warszawa 1929, s. 1-2.

156 Ibidem, s. 3.
} 
kryzys gospodarczy i kredytowy" 157 . Dostrzegał wzajemne oddziaływanie, ale nie stwierdzał, która sfera gospodarki wpływa w sposób decydujący na powstanie kryzysu powszechnego.

W. Grabski analizował szczegółowo kryzys agrarny, ponieważ dominującym działem gospodarki polskiej było rolnictwo. Niemniej istotne było to, że zagadnienia agrarne znał najlepiej zarówno od strony teoretycznej, jak i praktycznej. W pracach innych badaczy za czynnik sprawczy i główne źródło kryzysu powszechnego uznaje się depresję w sektorze rolnym ${ }^{158}$.

Grabski zastanawiał się też, czy kryzysy ekonomiczne są do uniknięcia. Wychodził z założenia, że fazy koniunktury są „,rodzajem niezłomnego prawa”. Zatem kryzysy są obiektywnym zjawiskiem i z tego powodu nie można ich uniknąć. Jednak, wychodząc z założenia, że najlepszym barometrem poziomu faz koniunktury jest stopa procentowa, to za jej pośrednictwem można wpływać na przyspieszenie okresu ożywienia i rozkwitu. Z kolei na wysokość stopy procentowej oddziałuje silnie polityka każdego banku emisyjnego i można zawsze ją zmniejszyć w razie nadmiernej ekspansji „ducha spekulacji”" ${ }^{159}$. Jak wykazały badania prowadzone w Stanach Zjednoczonych i Niemczech, kryzysu przy celowej działalności banków emisyjnych można uniknąć, a przynajmniej sporządzić prognozę o jego zbliżaniu się ${ }^{160}$.

Grabski proponował wprowadzić do gospodarki rynkowej „znaczne korektywy", tworząc więcej trustów i karteli. Wyrażał się też z uznaniem o włoskim systemie korporacji ${ }^{161}$.

Zwracał się do producentów, aby w pogoni za większym zyskiem kierowali się umiarkowaniem i produkowali na podstawie ,prawidłowo podejmowanych przewidywań" ${ }^{162}$. Głębokie zrozumienie zjawisk i procesów gospodarczych, umiejętność wnikania $\mathrm{w}$ ich treść pozwalała mu nakreślić prawdopodobny przebieg zbliżającego się kryzysu i sformułować szereg cennych wskazówek

${ }^{157}$ W. Grabski, Kryzysy rolnicze światowe..., s. 51.

158 J. A. Estey, op.cit., s. 138 I 194-195; T.W. Szultz, Agriculture in an Unstable Economy, New York 1945; E. O. Heady, Economics of Agricultural Production and Resource Use, New York 1925.

159 „W przebiegu tych faz konjunktury główną rolę, jak widzimy, odgrywa ruchliwość kapitału, tkwiącego $\mathrm{z}$ jednej strony $\mathrm{w}$ walorach giełdowych, $\mathrm{z}$ drugiej $\mathrm{w}$ zapasach towarów, $\mathrm{z}$ trzeciej $\mathrm{w}$ udzielanych kredytach. Przerzucanie się kapitału $\mathrm{z}$ jednej płaszczyzny do drugiej pozwala obserwować w każdej z faz konjunktury zbliżanie się fazy następnej: pozwala stawiać prognozę. Następstwo faz konjunktury staje się rodzajem niezłomnego prawa" (W. Grabski, Kryzysy światowe..., s. 9).

${ }^{160}$ W. Grabski, Polityka ekonomiczna ..., s. 17.

${ }^{161}$ W. Grabski, Kryzysy światowe..., s. 9.

162 Ibidem, s. 10. 
dotyczących środków zaradczych, które mogły złagodzić jego skutki ${ }^{163}$. Pogląd Grabskiego, co do aprobaty włoskiego systemu korporacji (centralizacja zarządzania gospodarką) jest dość zaskakujący, bowiem wielokrotnie opowiadał się on za mechanizmem wolnej konkurencji, nieskrępowanej ograniczeniami instytucjonalnymi.

W. Grabski analizował kryzys rolniczy w świecie i w Polsce. Czynił to na bieżąco, wraz z jego przebiegiem (w latach 1929-1931). Zaznaczał przy tym, że po kilku latach niektóre spostrzeżenia być może będą wymagały korekty. W jego mniemaniu kryzys rolniczy może być światowy, może też dotyczyć kilku krajów („miejscowy”). Bywały też kryzysy ograniczone do pewnych płodów rolnych, np. wystąpił kryzys buraka cukrowego, żyta, pszenicy. Przeprowadził, w oparciu o bardzo bogatą statystykę, szczegółową analizę produkcji i cen artykułów rolnych oraz zdolności konsumpcyjnej poszczególnych społeczeństw ${ }^{164}$.

Doszedł do wniosku, że aktualny kryzys rolny w świecie jest konsekwencją „raczej nadprodukcji niż podkonsumpcji” i że jest efektem nadprodukcji światowej, a nie europejskiej ${ }^{165}$. Główną przyczyną był wzrost produkcji roślinnej. W latach dwudziestych zwiększył się areał upraw w wielu krajach oraz wzrosła wydajność z hektara (stosowanie maszyn i większych nakładów kapitałowych). Szczególny wpływ miało forsowanie uprawy pszenicy w Stanach Zjednoczonych i Kanadzie, a także w Argentynie, Południowej Afryce, Australii i Nowej Zelandii. W konsekwencji doszło do nagromadzenia zbyt dużych zapasów tego zboża oraz spadku cen, który postępował w Ameryce, poczynając od $1925 \mathrm{r}$. i wywołał następnie załamanie się cen na zboża w Europie (w 1929 r., $\mathrm{w}$ niektórych krajach o połowę $\mathrm{w}$ porównaniu do okresu poprzedzającego kryzys).

W innej pracy Grabski upatrywał główną przyczynę kryzysu rolniczego w świecie w obniżeniu ,zdolności nabywczej Europy”. Na Starym Kontynencie nasiliła się tendencja zmierzająca do zmniejszania konsumpcji żyta i owsa, powodowana zmianami $\mathrm{w}$ strukturze spożycia społeczeństw europejskich ${ }^{166}$. Spadek popytu, a co za tym idzie, cen na zboża, tłumaczy Grabski jeszcze jedną

${ }^{163}$ A. Żabko-Potopowicz, Ś.p. Władysław Grabski, „Ekonomista” 1938, nr 1, s. 8.

${ }^{164}$ Ibidem, s. 20-43. Obliczenia statystyczne.

${ }^{165}$ W. Grabski, La crise agricole en Europe, Warszawa 1931, s. 6.

166 „Natomiast co do konsumpcji żyta i owsa spadek ten wydaje się niewątpliwym. Żyto stanowi poważny środek pożywienia głównie ludności wiejskiej i najuboższej miejskiej i to tylko w niektórych krajach na północy i wschodzie Europy. Ma ono zatem ograniczony zbyt, który stale maleje właśnie przy postępującej naprzód urbanizacji, przyczem kurczenie się konsumpcji nie ma co do żyta żadnej zasadniczej i trwałej kompensaty. Spadek ten zresztą nie jest zbyt silnym, bo odpływ ludności wiejskiej do miast nie jest dziś tak znaczny, jak przed wojną” (ibidem, s. 34). 
przyczyną, a mianowicie - zwiększeniem konsumpcji produktów zwierzęcych, jako bardziej wartościowych dla sprawności organizmu ludzkiego. Powoływał się przy tym na pracę dr Kurta Rittera z Berlina ${ }^{167}$.

Poza tym kryzys rolniczy w Europie powodowała konkurencja krajów o mniejszych kosztach produkcji oraz powiększanie się ciężarów publicznych i wzrost stopy procentowej, a także polityka niektórych rządów, dążących do utrzymania cen artykułów spożywczych na niskim poziomie ${ }^{168}$.

$\mathrm{W}$ rolnictwie, w przeciwieństwie do przemysłu, trudno ograniczyć rozmiary produkcji. W większości gospodarstw wytwórczość nie może być zatrzymana, ponieważ stanowi naturalne podłoże egzystencji dużych zbiorowości. W razie spadku cen poniżej opłacalności możliwe jest obniżanie nakładów. Jednak, aby doprowadzić ceny do poziomu opłacalności, proces ten może trwać nawet kilka lat $^{169}$.

W. Grabski zwracał uwage na wpływ urodzaju oraz nieurodzaju na ceny artykułów rolnych. Lata dużego urodzaju są niebezpieczne dla funkcjonowania rynku rolnego, ponieważ wywołują nadmierny spadek cen. Urodzaj wyższy od przeciętnego transferuje na rynek większą ilość towarów, co stanowi podłoże do tego, aby cena produktu mogła spaść w większym stopniu od wzrostu plonów. Kryzys w rolnictwie może pojawić się również w czasie wyjątkowego nieurodzaju, podczas którego może zabraknąć artykułów na sprzedaż, aby pokryć koszty produkcji. Nieznaczny spadek cen nie musi spowodować kryzysu. Taki niewielki spadek ma miejsce, gdy część urodzaju zostanie zmagazynowana lub gdy rynek jest pozbawiony zapasów lub pojawiają się warunki sprzyjające gromadzeniu zapasów ${ }^{170}$.

W. Grabski poświęcał dużo uwagi kryzysowi rolnemu w Polsce. Wskazywał przyczyny zewnętrzne i wewnętrzne. Do pierwszych zaliczał wpływ kryzysu w świecie i w Europie (spadek cen zbóż) oraz brak zagranicznych rynków zbytu na żyto. Duży urodzaj w 1929 r., będący „wynikiem siły wyższej” sprawił, że zaistniała konieczność eksportu zboża. Polska przed kryzysem bardzo mało eksportowała, często nawet importowała żyto. Nie miała zatem otwartych rynków zbytu. W okresie kryzysu wszystkie zagraniczne rynki były niedostępne. Nadmiaru produkcji nie mógł pochłonąć rynek wewnętrzny i ceny produktów zbożowych załamały się. Sytuację pogorszył spadek konsumpcji produkcji roślinnej (żyta, owsa i ziemniaków) ${ }^{171}$.

\footnotetext{
${ }^{167}$ Tendencje rozwojowe rolnictwa światowego, „Rolnictwo”, wrzesień 1929.

${ }^{168}$ W. Grabski, Kryzys rolniczy..., s. 30.

${ }^{169}$ W. Grabski, Kryzysy rolnicze światowe..., s. 6-7.

${ }^{170}$ Ibidem, s. 5-6 i 10.

${ }^{171}$ Ibidem, s. 40-44.
} 
Przyczyny wewnętrzne miały decydujący wpływ na kryzys rolny w Polsce, a zwłaszcza na jego głębokość i długotrwałość. Szczególnie dotkliwy był brak taniego kredytu i środków powstających z kapitalizacji wewnętrznej, która była słabo rozwinięta i nie stwarzała warunków dla rozwoju kredytu długoterminowego. Błędna była też polityka zbożowa, zwłaszcza w 1928 r., kiedy to rząd podjął działania ochraniające konsumenta (przed podwyżkami cen) i nie przewidział spadku cen na wiosnę 1929 r. Niesłusznie liczył również na utworzenie w 1929 r. instytucji kredytu długoterminowego w oparciu o kredyty zagraniczne $^{172}$. Rolnictwo w Polsce, wbrew sygnałom, jakie dawał ruch cen na rynkach światowych, nastawione było zbyt jednostronnie na produkcję żyta i owsa, zaniedbując uprawę pszenicy, na którą zapotrzebowanie zgłaszał rynek wewnętrzny ${ }^{173}$.

W. Grabski, mimo że od 1926 r. wycofał się z działalności publicznej, analizując koniunkturę i kryzysy gospodarcze, sugerował rozwiązania, które byłyby pomocne w działalności rządu. Przestudiował w tej kwestii prace ekonomistów polskich i zagranicznych (nie podaje nazwisk autorów). Pisze tylko, że metodami walki z kryzysem i stosowaniem środków zaradczych zajmują się ekonomiści całego świata. Istniały również teorie polskie. Jedna z nich zalecała stworzenie wysokiego poziomu cen na artykuły rolne, gdyż wówczas zwiększyłyby się dochody producentów rolnych, a w konsekwencji wzrosłaby siła nabywcza ludności wiejskiej. Wprowadzenie w życie tej teorii napotykało jednak poważne trudności $\mathrm{z}$ powodu niskiego poziomu cen światowych na produkty rolne. Ceny można i należy podnieść - według drugiej koncepcji - ale poprzez obniżenie wartości pieniądza (dewaluację), co również zwiększyłoby niską siłę nabywczą chłopstwa w stosunku do zdolności nabywczej innych warstw społeczeństwa.

Wśród wielu ekonomistów, zarówno polskich, jak i zagranicznych, panował pogląd, że kryzysu nie należy w ogóle zwalczać. Kryzys, według tej teorii, jest jedną z faz koniunktury, po której występują następne, prowadzące do ożywienia i rozkwitu. Nie należy zatem z nim walczyć, gdyż pogarsza to tylko sytuację, przedłużając jego trwanie. Tymczasem szereg bankructw przyspieszyłoby ustąpienie kryzysu, zgodnie z działaniem praw ekonomicznych. Grabski uważał, że ta teoria, zwana teorią automatyzmu gospodarczego, może mieć zastosowanie w praktyce tylko w przypadku kryzysu o łagodnym przebiegu. W sytuacji jednak kryzysu tak ostrego, jaki nastąpił po 1929 r., zastosowanie środków zaradczych było koniecznością. Wprawdzie tego typu podejście przedłużało czas trwania kryzysu, ale zmniejszało jego uciążliwość dla społeczeństwa ${ }^{174}$.

\footnotetext{
172 Ibidem, s. 43.

173 Ibidem.

${ }^{174}$ W. Grabski, Polityka ekonomiczna ..., s. 22.
} 
Po prezentacji poszczególnych teorii, przechodzi Grabski do przedstawienia praktycznych środków zaradczych służących zwalczaniu kryzysu w rolnictwie. Najpierw podaje przykłady ich stosowania w poszczególnych państwach. W Stanach Zjednoczonych wprowadzono ograniczenie produkcji, płacąc rolnikom odszkodowania ze skarbu państwa za pozostawienie części gruntów odłogiem. Jest to pewnego rodzaju forma wydzierżawienia pól uprawnych. Nadprodukcja wprawdzie zmniejszyła się, ale wzrost cen na artykuły rolne nie nastąpił ze względu na nadmierne zapasy. W Niemczech pojawiły się duże nadwyżki produkcji rolnej, ale udało się je „upłynnić”, zwiększając eksport. Jednocześnie wprowadzono cła zaporowe, uniemożliwiające import zboża. W Jugosławii, Norwegii, Szwajcarii i Czechosłowacji podjęto regulację produkcji za pomocą państwa, stosując przede wszystkim monopol zbożowy, ułatwiający eksport pszenicy lub żyta ${ }^{175}$. W niektórych krajach obowiązywał system cen minimalnych, wyznaczanych przez państwo. Dawał on pozytywne wyniki głównie w tych krajach, w których funkcjonował monopol zbożowy. Podsumowując, W. Grabski pisze, że działania antykryzysowe w rolnictwie będą skuteczne wówczas, gdy podniesie się dobrobyt społeczeństwa w całym świecie, a co za tym idzie - nastąpi wzrost popytu na artykuły rolne ${ }^{176}$.

W Polsce, gdzie gospodarka była w dużym stopniu uzależniona od rolnictwa, należało podjąć cały szereg środków zaradczych, aby w przyszłości nie dopuścić do kryzysu rolnego. W. Grabski przywiązywał dużą wagę do eksportu płodów rolnych i odpowiedniej polityki celnej. Twierdził, że Polska powinna być krajem eksportu rolnego.

Prawie wszystkie kraje europejskie od 1933 r. stosowały premie eksportowe, aby wywieźć za granicę nadmiar produktów rolnych. Polska wprowadziła premie eksportowe dla zbóż i artykułów zwierzęcych. W 1933 r. środki na nie uzyskano przez opodatkowanie przemysłu w wysokości $10 \%$ dodatku do podatku obrotowego ${ }^{177}$.

${ }^{175}$ Ibidem, s. 22-23.

176 „Na kongresie w Genewie rolnicy silnie podkreślili to, że rozkwit rolnictwa mógłby przynieść wielką ulgę ludzkości, którą trapi klęska bezrobocia. Ale właśnie dlatego, by rolnictwo mogło dojść do stanu rozkwitu, koniecznem jest, by mogło osiągnąć wyższe ceny za swe produkty' w tym znowu celu koniecznem jest, by ogólne warunki bytu całych społeczeństw i części świata uległy poprawie. Przyczyny kryzysu agrarnego są bardzo głębokie, a z tego też wypływa, że i środki zaradcze nie są łatwe do znalezienia i skutecznego zastosowania” (W. Grabski, Kryzysy rolnicze światowe..., s. 16 i 30).

177 W. Grabski, Polityka ekonomiczna ..., s. 22. 
W 1935 r. dokonano modyfikacji polityki popierania eksportu. Zwiększono mianowicie środki przeznaczone na premiowanie wywozu artykułów hodowlanych. Przyczyniło się to m.in. do powstrzymania spadku dochodów wsi ${ }^{178}$. Eksport zwierząt żywych wzrósł z $27 \mathrm{mln}$ zł w 1935 r. do $59 \mathrm{mln}$ zł w 1938 r. ${ }^{179}$

W. Grabski, aby pomóc polskim rolnikom, apelował o zniesienie wszelkich ceł wywozowych oraz wprowadzenie ceł ochronnych importowych ${ }^{180}$.

W końcu lat 30. Polska znajdowała się na 12 miejscu, wśród 20 państw, pod względem wysokości obciążeń celnych, należała zatem do krajów o przeciętnym obciążeniu importu opłatami celnymi ${ }^{181}$.

W. Grabski ubolewał, że część polskich ekonomistów, zajmujących się rolnictwem, stoi na stanowisku zniesienia barier celnych w stosunkach z bardziej zamożnymi krajami, m.in. z Niemcami, co stwarzało możliwość uzyskania wyższych cen na polskie produkty rolne. Taki pogląd przedstawił prof. Burek w pracy Środki naprawy obecnych stosunków rolniczych oraz Stefan Schmidt w opracowaniu Stan i kierunki rozwoju rolnictwa w Polsce. Stanowisko tych autorów nie uwzględniało zupełnie - jak dowodził Grabski - realiów rynków zagranicznych. Niemcy, Czechosłowacja i Austria stały na gruncie ochrony celnej własnego rolnictwa. Ponadto wolny handel krył niebezpieczeństwo dla Polski, wynikające $\mathrm{z}$ tego, że zniesienie barier celnych między krajem gospodarczo słabszym a państwami bardziej rozwiniętymi skazuje $\mathrm{z}$ góry te słabsze na stałą podrzędną rolę i uległość pod każdym względem ${ }^{182}$.

W. Grabski miał pełną świadomość i zrozumienie dla polityki celnej prowadzonej przez państwa rozwinięte. Otóż koszt produkcji był wyższy w krajach „o starej kulturze rolnej”. Wartość ziemi jest bowiem nie tylko wyrazem wielkich, trwałych nakładów od wielu lat nagromadzonych na ich obszarze, ale także nakładów całego społeczeństwa, dążącego usilnie do zaspokojenia potrzeb konsumpcyjnych. Dlatego kraje „o starej kulturze rolnej” domagają się ochrony celnej, aby zahamować wzmożony przywóz artykułów rolnych z krajów o „kulturze nowej” ${ }^{183}$.

178 Z. Landau, J. Tomaszewski, Lata interwencjonizmu państwowego 1936-1939, Warszawa 1989, s. 470 .

${ }^{179}$ Maty rocznik statystyczny 1939, s. 171.

180 W. Grabski, Polityka ekonomiczna ..., s. 40.

181 Z. Landau, J. Tomaszewski, op.cit., s. 241-242.

182 W. Grabski, Kryzys rolniczy..., s. 23.

183 „Dlatego też w tych dziedzinach, które pozwalają drogą zastosowania maszyn na znaczne zwiększania wydajności, kraje nowe są najpoważniejszym konkurentem, jak to ma głównie miejsce przy uprawie pszenicy. Natomiast w produkcji okopowych, wymagających dużej ilości rąk 
Pogodzenie interesów państw tych dwóch obszarów nastręczało wiele problemów i trudno było znaleźć rozwiązanie kompromisowe. W. Grabski pisał: „Chcąc rozwijać własny eksport, trzeba godzić się na cudzy import, nie tylko rzeczy absolutnie niezbędnych, ale $\mathrm{w}$ ogóle tych, które mogą stanowić ekwiwalent w wymianie międzynarodowej" 184 .

Eksport z Europy do krajów zamorskich zmalał. Rynki pozaeuropejskie zapełniły się rodzimą produkcją. W Europie pojawiły się miliony bezrobotnych, co spowodowało ograniczenie konsumpcji. Rynek europejski dla produktów rolniczych uległ skurczeniu ${ }^{185}$.

Od 1929 r. producenci zamorscy ,zalewali” swym zbożem rynki europejskie, które - dla uniknięcia dalszego spadku cen - podwyższały taryfy celne. Ostrze tych taryf, skierowane w pierwszym rzędzie przeciwko krajom zamorskim, ugodziło jednak także Węgry, Jugosławię, Bułgarię i inne państwa, dla których wywóz pszenicy był podstawą całego ich eksportu.

Na konferencjach międzynarodowych, które odbywały się kolejno w 1930, 1931 i 1932 r., Niemcy wyraziły chęć udzielenia pomocy krajom naddunajskim (cła preferencyjne), ale pod warunkiem przeprowadzenia osobnych pertraktacji z każdym państwem i za cenę importu własnych towarów przemysłowych. $\mathrm{Na}$ konferencjach tych Polska podtrzymywała koncepcję solidarności państw południowo-wschodniej Europy. Francja zaś domagała się preferencji ogólnoeuropejskich, wysuwając ideę Paneuropy ${ }^{186}$.

W. Grabski zaliczał porozumienia międzynarodowe do najważniejszych środków zwalczania kryzysów w rolnictwie. Dwustronne układy międzypaństwowe uważał za niewystarczające. Powoływał się przy tym na porozumienia między Polską a Niemcami dotyczące eksportu polskiego żyta, które nie przyniosły spodziewanych rezultatów. Opowiadał się za porozumieniami regionalnymi, bądź też światowymi: „W polityce gospodarczej państw współczesnych ciągłe tarcia wzajemne, które na kryzysy rolnicze wyraźny wpływ wywierają, tamując dostęp do szerszych rynków dla różnych produktów

roboczych, oraz przy produkcji zwierzęcej, w której maszynizm ma małe pole zastosowania, kraje o starej kulturze łatwo wytrzymują konkurencję w nowemi.

Kraje, w których znaczna większość ludności jest poświęcona rolnictwu, zmuszone są wywozić swoje produktu do krajów, mających bardziej gęstą ludność miejską. Gdy jednak takiemu wywozowi stoją na przeszkodzie utrudnienia graniczne i celne ze strony tych drugich krajów, staje się to dla pierwszych źródłem kryzysu rolnego" (W. Grabski, Kryzysy rolnicze..., s. 11).

${ }^{184}$ Ibidem, s. 16.

185 Ibidem, s. 15.

${ }^{186}$ W. Grabski, Polityka ekonomiczna ..., s. 22. 
i stwarzając trudne dla nich konjunktury. Tarcia te wysuwają na czoło sprawę porozumień, bądź lokalnych między odnośnemi państwami, bądź powszechnych międzynarodowych"187.

W. Grabski przedstawił w 1931 r. Komitetowi Federacji Współpracy Europejskiej raport, w którym zawarł koncepcję zbliżenia dwóch ugrupowań regionalnych: państw Europy centralnej i wschodniej, tj. Bułgarii, Rumunii, Węgier, Jugosławii i Polski oraz Europy południowej i zachodniej, tj. Włoch, Węgier, Czechosłowacji i Niemiec ${ }^{188}$.

Porozumienie tych państw byłoby możliwe pod warunkiem, że dotyczyłoby stricte spraw gospodarczych. Dlatego też włączenie Francji byłoby niewskazane, ponieważ ugrupowanie nabierałoby charakteru politycznego. Grabski wskazywał, że kraje Europy centralnej i wschodniej, współdziałając ze sobą, będą w korzystniejszej sytuacji w walce o rynek angielski. Generalnie zaś, jeśli dojdzie do porozumień eksporterów i importerów w Europie centralnej, państwa uprzemysłowione znajdą się w gorszym położeniu ${ }^{189}$.

W. Grabski w kwestii międzynarodowej współpracy w dziedzinie rolnictwa doszedł do następujących konkluzji:

- współpraca międzynarodowa, aby była skuteczna wymaga gruntownych studiów przygotowawczych; porozumienia między eksporterami muszą ograniczyć wzajemną konkurencję,

- jeśli spadną ceny produktów rolnych w państwach eksporterów południa i wschodu Europy należy wykazać „prawdziwą solidarność europejską”,

- współpraca nie powinna procedować środków, które łączyłyby jedne kraje lub eliminowałyby inne,

- nie można eliminować ZSRR, wielkiego eksportera z dużymi możliwościami rozwoju,

- wspomagać organizację kredytu rolnego,

- dążyć do eliminacji rygorystycznego protekcjonizmu celnego,

- idea regulacji produkcji nie może być „ekwiwalentem” etatyzmu ${ }^{190}$.

$\mathrm{W}$ drugiej połowie lat 30 . rozwiały się ostatecznie nadzieje na utworzenie bloku regionalnego, proponowanego m.in. przez polityków polskich. Udało się jedynie podpisać umowy międzynarodowe dotyczące reglamentacji cukru i drewna. W obu tych przedsięwzięciach wzięła udział Polska ${ }^{191}$. Porozumienia

\footnotetext{
${ }^{187}$ W. Grabski, Kryzysy rolnicze..., s. 16.

${ }^{188}$ W. Grabski, La crise agricole..., s. 27.

${ }^{189}$ Ibidem, s. 28-30.

${ }^{190}$ Ibidem, s. 35-36.

${ }^{191}$ Z. Landau, J. Tomaszewski, op.cit., s. 465.
} 
te nie zmieniły trudnej sytuacji krajów Europy środkowej i południowo-wschodniej w dziedzinie handlu międzynarodowego, zwłaszcza w zakresie eksportu produktów rolnych.

W. Grabski za najlepszą metodę „ulżenia” polskiemu rolnictwu, bez odnoszenia cen na jego produkty, uznawał obniżenie kosztów produkcji. Można było to osiągnąć dwoma sposobami: zmniejszeniem cen na środki produkcji (maszyny, materiały budowlane, nawozy sztuczne) oraz przyspieszeniem melioracji i budowy dróg dojazdowych. Na wzrost opłacalności produkcji rolnej miałoby wpływ również obniżenie cen na artykuły przemysłowe, służące do konsumpcji własnej ${ }^{192}$.

Wpływ na poprawę sytuacji $\mathrm{w}$ rolnictwie oraz redukcję negatywnych skutków kryzysu mógł zapewnić rozwinięty system kredytowy. Pozwalał on producentom rolnym - zdaniem Grabskiego - powstrzymać się od dostarczania na rynek nadmiaru produktów po zbyt niskich cenach. Duży urodzaj jest niebezpieczny dla rolników tam, gdzie kredyt jest nierozwinięty lub został zachwiany. System kredytowy ułatwiał też rozwój intensywnej gospodarki rolnej, zwłaszcza zakup środków produkcji ${ }^{193}$.

W. Grabski optował za potanieniem kredytu rolnego. Zaznaczał, że kraje, które mają wysoką stopę procentową, nie będą mogły konkurować z państwami o niskiej stopie, gdyż choćby miały inne niższe koszty produkcji, to stopa procentowa zawsze podniesie wydatki. Kraje, które znajdą się w takiej sytuacji, będą szukały wyrównania szans dla swego rynku w protekcji celnej ${ }^{194}$.

Tymczasem w Polsce stopa procentowa zarówno kredytu krótkoterminowego, jak i długoterminowego była wysoka (do 1932 r. - odpowiednio: 10\% i 7\% w stosunku rocznym $)^{195}$.

Szczególnie istotne znaczenie dla rolnictwa miał kredyt długoterminowy. Długi okres spłaty stwarzał bowiem możliwości rozwoju rolnictwa w przyszłości. Takiej szansy nie dawały pożyczki krótkookresowe. Drobni rolnicy zadłużali się u lichwiarzy. Zwiększały się ciężary z tego tytułu, często znacznie poważniejsze od podatkowych. Wprawdzie rząd polski ułatwiał rolnikom uzyskanie kredytów,

192 „Koszty produkcji dla rolnika nie kończą się w jego gospodarstwie. Gdy rolnik ma trudności w dowozie swego towaru na targ lub stację kolejową, koszty produkcji dla niego rosną niepomiernie. Na tem polu w Polsce są wielkie braki. Bez ich usunięcia trudno myśleć o tem, by postęp rolniczy mógł duże poczynić postępy i znajdzie on barjery dla siebie nie do przebycia" (W. Grabski, Kryzys rolniczy..., s. 28).

${ }^{193}$ Ibidem, s. 8.

${ }^{194}$ W. Grabski, Zagadnienie postęu rolniczego wobec kryzysu, Warszawa 1930, s. 20.

195 Dokumenty do dziejów Państwowego Banku Rolnego, t. I: 1938-1944, wstęp i oprac. M. Kłusek, s. 15-16 i 26-27. 
ale obniżanie stóp procentowych postępowało dużo wolniej niż $\mathrm{w}$ innych krajach ${ }^{196}$. Był to - według oceny Grabskiego - „,najboleśniejszy punkt”, hamujący rozwój gospodarki polskiej. Za dobre rozwiązanie uważał zorganizowanie systemu kredytowego pod zastaw zboża ${ }^{197}$.

Kredyt pod zastaw zbóż Państwowy Bank Rolny uruchomił od 1928 r. Zatem istniała zbieżność w czasie między opracowaniem Grabskiego (ukazało się w 1929 r.) a decyzją PBP. Pożyczek udzielano na trzy miesiące. Oprocentowanie wynosiło $10 \% \mathrm{w}$ stosunku rocznym i było płatne $\mathrm{z}$ góry przy pobieraniu pożyczki, bądź przy jej prolongowaniu ${ }^{198}$. Przy braku gotówki, mimo wysokich odsetek, kredyt pod zastaw zbóż cieszył się wśród rolników dużym zainteresowaniem ${ }^{199}$. W 1937/1938 r. rząd przeznaczył na nie 43,5 mln zł. PBR udzielił ogółem w 1938 r. 235 mln zł kredytów krótkoterminowych (w 1927 r. -

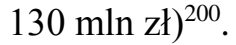

Doniosłym przedsięwzięciem rządu było przygotowanie oferty kredytu długoterminowego na melioracje rolne. Rozwój melioracji był jednym z głównych postulatów W. Grabskiego, które pojawiały się w jego opracowaniach i działalności publicznej ${ }^{201}$. PBR udzielał od 1928 r. tych kredytów w 7\% obligacjach melioracyjnych na maksymalny okres do 15 lat $^{202}$.

Ważnym środkiem zaradczym $\mathrm{w}$ walce $\mathrm{z}$ kryzysem $\mathrm{w}$ rolnictwie była właściwa polityka oddłużeniowa i redukcja ciężarów nakładanych na rolników. W. Grabski uważał, że akcję oddłużania można przeprowadzić następującymi sposobami: odraczaniem terminu płatności, obniżeniem oprocentowania, redukcją sumy dłużnej i zmniejszeniem „rozwarcia” nożyc cen (stosunek cen artkułów przemysłowych do rolniczych). Pisał z uznaniem w końcu lat 30., że w Polsce podjęto skuteczną działalność oddłużeniową. Utworzono urzędy mające prawo odraczać licytację, zmniejszać oprocentowanie bieżące i umarzać

${ }^{196}$ Stopa procentowa w Banku Polskim obniżyła się z 8,3\% w 1927 r. do 4,5\% w 1938 r.; natomiast odpowiednio w Wielkiej Brytanii z 4,7 do 2\%, Niemczech - z 5,8 do 4\%, Francji - z 5,2 do 3\%, Stanach Zjednoczonych - z 3,8 do 1\% (Mały rocznik statystyczny 1939, s. 215).

${ }^{197}$ W. Grabski, Kryzys rolniczy..., s. 29.

198 M. Kłusek. Uruchomienie kredytu warrantowo-lombardowego rolniczego $w$ Polsce międzywojennej, „Roczniki Naukowe Stowarzyszenia Ekonomistów Rolnictwa i Agrobiznesu” 2007, T. IX, z. 4.

199 Zob. szerzej: Dokumenty do dziejów..., s. 15-28.

${ }^{200}$ Maty rocznik statystyczny 1939, s. 226; Z. Landau, J. Tomaszewski, op.cit., s. 249.

${ }^{201}$ W. Grabski, Melioracje rolne w czasie kryzysu rolniczego, „Rolnictwo” 1933/34, T. I, z. 3 , s. 306 .

${ }^{202}$ S. Turczynowicz, Z zagadnień polityki melioracyjnej $w$ Polsce, „Rolnictwo”, R. I, T. I, s. $271-280$. 
zaległości. Pewną ulgę przyniosło producentom rolnym obniżenie stopy procentowej od pożyczek w Banku Rolnym i Towarzystwie Kredytowym Ziemskim oraz utworzenie Banku Akceptacyjnego, którego zadaniem była konwersja długów rolniczych. Żądania rolników dotyczące umorzenia długów napotykały jednak energiczny sprzeciw wierzycieli, którzy w ostatnich latach ponieśli poważne straty (inflacja, moratoria, obniżenie oprocentowania) ${ }^{203}$. Mimo opozycji licznej grupy posłów w parlamencie rząd w latach 30. wykazał się dużą determinacją $\mathrm{W}$ realizacji polityki konwersji i uporządkowania długów rolniczych ${ }^{204}$.

Skutki kryzysu w rolnictwie odczuwała cała gospodarka i polskie społeczeństwo. W tej sytuacji rząd zdecydował się na podjęcie skutecznej polityki oddłużeniowej. Jej efekty uwidoczniły się po 1932 r. Dużą ulgę przyniosło rolnikom zmniejszenie oprocentowania pożyczek oraz konwersja zadłużenia, która objęła wszystkie formy kredytowania. Prowadzono ją z dużym powodzeniem od 1932 do 1939 r. W 1932 r. oprocentowanie pożyczek krótkoterminowych obniżono o 1,5\%, zaś kredytu melioracyjnego - o 2,5\%. Akcja oddłużeniowa, prowadzona za pośrednictwem Banku Akceptacyjnego, spowodowała umorzenie kredytów krótkoterminowych w latach 1934-1938 na sumę około $1606 \mathrm{mln}$ zł, w tym na PBR przypadało $291,5 \mathrm{mln} \mathrm{zt}^{205}$. Natomiast konwersja kredytów w obligacjach melioracyjnych zmniejszyła zadłużenie rolników ze 111,5 mln zł w 1933 r. do około $58 \mathrm{mln}$ zł w 1939 r. ${ }^{206}$

Najprostszym wyjściem z kryzysu byłoby ograniczenie produkcji rolnej i zmiana jej kierunków. W Polsce zbyt wielkie obszary zasiewano żytem i owsem, co powodowało nadprodukcję tych zbóż. Należało też zwiększyć produkcję zwierzęcą, na którą było zapotrzebowanie eksportowe oraz uprawy roślin przemysłowych (lnu i konopi). Zmiany te, w przekonaniu Grabskiego, nie były jednak łatwe do wprowadzenia. $\mathrm{Na}$ rolnikach ciążyło wiele różnych płatności. Spadek cen w okresie kryzysu wymuszał zwiększenie sprzedaży artykułów rolnych, umożliwiające pokrycie wydatków, co z kolei zaostrzało kryzys. Ponadto chłopi w Polsce nie byli przygotowani mentalnie do zmiany sposobu gospodarowania ${ }^{207}$.

${ }^{203}$ W. Grabski, Polityka ekonomiczna..., s. 22.

${ }^{204}$ Z. Landau, J. Tomaszewski, op.cit., s. 277-278.

${ }^{205}$ Maty rocznik statystyczny 1939, s. 230.

${ }^{206}$ M. Kłusek, Konwersja zadlużenia rolniczego jako element walki państwa z kryzysem $w$ rolnictwie $w$ Polsce międzywojennej, „Roczniki Naukowe Stowarzyszenia Ekonomistów Rolnictwa i Agrobiznesu" 2009, T. I, z. 2.

${ }^{207}$ W. Grabski, Polityka ekonomiczna ..., s. 22; idem, Kryzys rolniczy ..., s. 8 i 51-52. 
W. Grabski, analizując naturę kryzysu w rolnictwie, doszedł do wniosku, że poprawa koniunktury wymaga przede wszystkim obniżenia kosztów produkcji. Dotychczas poszukiwano sposobów, aby jak najwięcej produkować, a nie jak najtaniej. Redukcję kosztów wytwarzania umożliwiał rozwój postępu technicznego i wiedzy rolniczej ${ }^{208}$.

Innowacje stosowane w rolnictwie, podobnie jak w przemyśle, wpływają na potanienie produkcji, odgrywają jednak w rolnictwie dużo mniejszą rolę. $\mathrm{W}$ tej dziedzinie, jak dowodzi Grabski, w procesie wytwarzania dominuje przyroda i sam człowiek. Maszyny tylko w niewielkim stopniu zastępują czynności rąk ludzkich. Postęp techniczny z trudnością przenika z kraju do kraju i dotyczy głównie środków produkcji, a tylko w niewielkim stopniu uprawy roślin i hodowli inwentarza ${ }^{209}$. Pogląd ten, jak pokazała przyszłość, stracił dość szybko swą aktualność.

W. Grabski zwracał uwagę, że najtaniej produkują kraje o „kulturze świeżej” i mało zaludnione, gdzie dominuje rolnictwo ekstensywne. Dużo większe koszty ponoszą kraje o „kulturze starej”, prowadzące gospodarkę intensywną. Zwiększają one wydajność, przeznaczając coraz większe środki na rozwój rolnictwa. Inaczej przedstawia się sprawa w krajach o „kulturze świeżej”, tam mniejszymi nakładami uzyskuje się od razu dużo większe plony ${ }^{210}$.

W. Grabski, kończąc rozważania na temat postępu technicznego w rolnictwie, stwierdza, że rozwój wiedzy ekonomiczno-rolniczej jest koniecznością, którą uświadomił społeczeństwu „obecny” kryzys. Zdawał sobie sprawę, że rolnicy są bezsilni w walce z przejawami kryzysu. Należało im pomóc m.in. dostarczając wiedzę, zwłaszcza fachową.

Jego zdaniem nauki ekonomiczno-rolnicze powinny znaleźć uznanie władz i społeczeństwa oraz uzyskać wysoką pozycję i autorytet dzięki swemu poziomowi naukowemu i ścisłej współpracy z praktyką. Zwracał uwagę, że poszczególne ośrodki nauki i praktyki były powiązane ze sobą funkcjonalnie, a nie organizacyjnie. Wyższe uczelnie rolnicze, stacje doświadczalne, Instytut Naukowy w Puławach, izby rolnicze pracują odrębnie. Organizacje rolnicze (do nich zalicza też izby rolnicze) nie mają organów, za pomocą których mogłyby

${ }^{208}$ W. Grabski, Zagadnienie postępu..., s. 17 i 21.

${ }^{209}$ Ibidem, s. 5.

210 „Postęp techniczny i stosowanie różnych wynalazków działa na potanienie produkcji rolnej tak samo, jak przemysłowej. Ale w odróżnieniu od działalności przemysłowej, w której postęp ten daje bezwzględną przewagę w razie stosowania wszelkich ulepszeń w rolnictwie nie są w stanie zniwelować tego zasadniczego prawa ekonomicznego w produkcji rolnej, które się wyraża w zmniejszaniu się wydajności nakładów przy potęgowaniu ich napięcia” (W. Grabski, Kryzys rolniczy..., s. 6). 
stawiać określone wymagania nauce ${ }^{211}$. Grabski apelował o utworzenie przynajmniej jednego wydziału ekonomiczno-rolniczego, w którym funkcjonowałyby specjalizacje w dziedzinie organizacji gospodarstw, polityki agrarnej, agronomii społecznej, spółdzielczości i polityki ekonomiczno-rolniczej. Rozwój ten wymagał zorganizowania liczniejszych katedr ekonomicznych oraz większego zatrudnienia „sił pomocniczych”. Ze względu na duży kompleks zagadnień ekonomiczno-społecznych w rolnictwie wykształcenie ogólno-ekonomiczne było niewystarczające. W związku z tym - konkluduje Grabski - nauki ekonomiczno-rolnicze powinny być przedmiotem odrębnych studiów i specjalizacji naukowych. Potrzebni są bowiem ludzie o wysokich kwalifikacjach. Obserwowany w Polsce postęp prac w zakresie polityki agrarnej i spółdzielczości rolniczej nie jest w stanie rozwiązać trudnych problemów rolnictwa, ponieważ nie stanowią one przedmiotu studiów. „A studia te są konieczne i potrzebne, zarówno jeśli idzie o kryzys, jak i o stronę ekonomiczną życia rolniczego" ${ }^{212}$. Uważał też, że należy pogłębić wiedzę w zakresie funkcjonowania gospodarstw rolnych w krajach słowiańskich ${ }^{213}$.

Akcja szerzenia oświaty rolniczej powinna iść w kierunku podniesienia wśród rolników zdolności wytwórczych tak, aby przy ograniczonych czynnikach produkcji mogli osiągać dobre wyniki. Dzięki temu wytwórcy będą uzyskiwali środki pieniężne niezbędne do osiągnięcia dalszych efektów ekonomicznych ${ }^{214}$.

Wykształceni rolnicy mogliby kupować nawozy sztuczne $\mathrm{z}$ większym namysłem i nie zawsze słuchać gotowych recept, głoszonych przez sprzedających. Bardziej rozumnie będą je stosować i z większą rozwagą przystępować do melioracji ${ }^{215}$. Wiedza fachowa umożliwiłaby im śledzenie ruchu cen produktów roślinnych i zwierzęcych. Jeśli ceny artykułów zwierzęcych „lepiej stoją od cen produktów roślinnych", to uznają, że trzeba więcej tych ostatnich używać do spasania inwentarzem żywym ${ }^{216}$.

${ }^{211}$ W. Grabski, Zagadnienie postępu..., s. 25-26.

${ }^{212}$ Ibidem, s. 27-29.

${ }^{213} \mathrm{~W}$. Grabski, O potrzebie napisania historii rozwoju nauki o spotecznem gospodarstwie agrarnem wśród narodów stowiańskich. Odb. ze Sprawozdania z posiedzenia Towarzystwa Naukowego Warszawskiego, Warszawa 1933.

${ }^{214}$ W. Grabski, Polityka ekonomiczna ..., s. 31.

215 „Inny, który wziął się do stosowania nawozów nie pod wpływem podszeptów kapitalizmu, czyli ducha przedsiębiorczego, a pod wpływem głębokiego zrozumienia potrzeb własnej gleby i roślin na nich uprawianych, ten zapewne pozostanie wierny swoim spostrzeżeniom o potrzebie zasilania gleby nawozami sztucznemi i najwyżej nieco swe dawki ograniczy i zmodyfikuje. Kto brał dostępny kredyt na melioracje bez właściwego rozumienia może ponieść nawet straty" (W. Grabski, Zagadnienie postępu..., s. 23-24).

216 „Spadek wywołany spasaniem tanich produktów kryzysu nie spowoduje, gdyż będzie on rezultatem obniżenia kosztów produkcji. Na dłuższą metę konieczne jest jednak rozszerzenie 
Jaką politykę powinien stosować rząd wobec kryzysu w rolnictwie? Grabski stwierdza, że w wielu krajach nie podejmuje się żadnej interwencji rządowej. W niektórych wprowadza się ochronę celną, np. w Niemczech, a także w Polsce. Jedno jest pewne, a mianowicie to, że polityka antyrolnicza państwa nie wywołuje kryzysu, ponieważ występuje on również i tam, gdzie jej nie ma, a jedynie go pogłębia. W Polsce za głębokość i długotrwałość kryzysu winę ponosił rząd, który popełnił szereg błędów i działał opieszale: „Okres dobrej konjunktury nie został u nas wykorzystany dla wzmocnienia naszego organizmu gospodarczego i uodpornienia go wobec kryzysu. W polityce rolniczej eksportowej i kredytowej popełnione były błędy, których dotychczas nie udało się sparaliżować" 217 .

\section{Rozwój gospodarczy}

W. Grabski doceniał rolę badań nad rozwojem gospodarczym. Wychodził z założenia, że zakres pojęcia rozwoju gospodarczego jest szerszy od pojęcia koniunktury. Badając rozwój gospodarczy, należy ujmować życie gospodarcze jako całość, tj. dochód narodowy, jego elementy składowe i zmiany w nim zachodzące, stan i dochodowość majątku narodowego, wydajność pracy „narodu” i jego „części składowych” oraz zmiany ilościowe i jakościowe poszczególnych parametrów ekonomicznych ${ }^{218}$.

Analizował różne teorie ekonomiczne i starał się konfrontować je z rzeczywistością gospodarczą. Wielu współczesnych ekonomistów podtrzymuje ten pogląd. B. Fiedor podkreśla, że zjawiska wzrostowe i stagnacyjne mają niezwykle złożony charakter. W związku z tym „bardziej zasadne wydaje się podejście «eklektyczne», to znaczy identyfikacja istoty, przejawów i źródeł omawianych zjawisk wzrostowych i stagnacyjnych oparta na dorobku wielu, niekiedy konkurujących między sobą, teorii i modeli" ${ }^{219}$.

Wyrażał przekonanie, że cykle koniunkturalne niekoniecznie muszą powodować rozwój gospodarczy. Nastąpi on jedynie wtedy, gdy procesy rozwojowe faz cyklu koniunkturalnego będą silniejsze od koniunktury w następnych fazach.

rynków wewnętrznych i zewnętrznych przy pomocy środków, które uczyniłyby tę produkcję dostępną dla najszerszych warstw ludności. Jest tu bardzo duże pole dla nauki i postępu rolniczego na niej opartego" (ibidem, s. 24).

${ }^{217}$ W. Grabski, Kryzys rolniczy..., s. 14 i 51-52.

${ }^{218}$ W. Grabski, Koniunktura, kryzysy..., s. 13.

${ }^{219}$ B. Fiedor, Wspótczesny wzrost gospodarczy - uwarunkowania strukturalne a koniunkturalne oraz potrzeba , eklektyczna” w teorii i polityce wzrostu, [w:] W. Grabski, Polityka ekonomiczna ..., s. 55. 
Przy przebiegu odwrotnym występuje nie rozwój, a spadek, przy równowadze zaś - stagnacja ${ }^{220}$.

Na rozwój gospodarczy wywierają wpływ różne czynniki. Obok ekonomicznych istotną rolę odgrywają uwarunkowania przyrodnicze oraz społeczne i polityczne. W. Grabski podaje szereg konkretnych przykładów ${ }^{221}$. Dostrzegał specyfikę rozwoju gospodarki polskiej. Pisał, że w polskim rolnictwie „ujawniają się siły społeczne silniejsze od czynników ekonomicznych". Znaczna część ziemi przechodziła w ręce drobnej własności; włościanie kupowali ziemię, aby zapewnić sobie egzystencję. W przemyśle rozbudowa ubezpieczeń socjalnych stanowiła klapę bezpieczeństwa przed ekspansją komunizmu, co wiązało się z polską racją stanu ${ }^{222}$.

W. Grabski dużo miejsca poświęcał metodzie prowadzenia badań: „Badania rozwoju gospodarczego tem przedewszystkiem muszą się różnić od badania konjunktur, że rozszerzać muszą znacznie pole obserwacji naukowej. Konjunktura interesuje się tem, co może wpłynąć na przebieg najbliższej fazy, rozwój musi się interesować i tem również, co oddziaływa na dalszą metę. Badania jego muszą być zatem bardziej wszechstronne, pełne dociekania, muszą wchodzić w rozróżnianie jakości przejawów"223. Badania są bardziej wiarygodne, jeśli niezależnie od danych ogólnych, uwzględnia się przeliczenia na poszczególne jednostki, dotyczące produkcji i konsumpcji. Konieczna jest też analiza porównawcza, obejmująca zwłaszcza państwa sąsiednie ${ }^{224}$. Badania naukowe muszą być prowadzone $\mathrm{z}$ zachowaniem objektywizmu. Obliczenia biur koniunktur, liczby i wykresy nie są wystarczające, aby wyjaśnić istotę rozwoju gospodarczego ${ }^{225}$. Wskazywał na potrzebę badań kompleksowych, prowadzonych

${ }^{220}$ W. Grabski, Polityka ekonomiczna ..., s. 16.

${ }^{221}$ Polityczne czynniki - wojna celna z Niemcami (1925 r.), przewrót majowy (1926 r.); przyrodniczy (nieurodzaj w 1925 r.); społeczny - strajk górników angielskich w 1926 r. (ibidem, s. 22).

${ }^{222}$ W. Grabski, Koniunktura, kryzysy..., s. 21-22.

${ }^{223}$ Ibidem, s. 15.

224 „Takiemi podstawami dla sądzenia o rozwoju gospodarczym winno być ustalenie tempa rozwojowego danego społeczeństwa w okresach poprzedzających (jak dla czasów obecnych to jest tempo w okresie przedwojennym), a z drugiej strony tempo tegoż rozwoju w społeczeństwach sąsiednich. Pierwszy probierz musi być brany pod uwagę, bo w każdem społeczeństwie tkwi świadomość jego bliższej przeszłości i wszystko, co w niej było dostatniego, urasta w tej świadomości do miary prawa i koniecznej potrzeby. Drugi czynnik winien być brany pod rozwagę dla tego, że żadne społeczeństwo nie może egzystować w izolacji i przy wzajemnem na siebie oddziaływaniu społeczeństw sąsiednich szybciej udzielają się jedne drugim poczucia idące w kierunku wzrostu potrzeb, niż przeszczepia się sama zdolność czynienia im radość" (ibidem, s. 18).

225 „Jeżeli jednak na zasadzie cyfr powyższych zechcemy sobie zdać sprawę z tego, w jakim stopniu rozwój gospodarczy kraju postąpił istotnie naprzód, w jakich warunkach zostały 
przez ekonomistów, historyków i socjologów. Szczególną rolę w tym względzie przypisywał badaniom historycznym ${ }^{226}$.

Badania nad rozwojem gospodarczym powinny stanowić podstawę do prowadzenia właściwej polityki ekonomicznej i społecznej. Mogłyby przyczynić się do usunięcia niedomagań, które są poważne i tkwią głęboko w polskiej gospodarce. Jeśli je poznamy gruntownie, to możliwe będzie podjęcie środków zaradczych. Wpłyną one również na zmianę świadomości społeczeństwa polskiego. Grabski był przekonany, że „Wtedy wniosą one do ogólnej orjentacji społeczeństwa pierwiastek nie tylko pozwalający na oddziaływanie w duchu unikania złych konjunktur i kryzysów, ale również i w duchu wzmożenia tempa rozwoju gospodarczego danego kraju w takiej mierze, by zapewnić temu krajowi właściwe miejsce w ogólnym wyścigu państw i społeczeństw na polu pracy"227.

Zdawał sobie sprawę, że zmiana mentalności nie jest rzeczą łatwą. Dla większości społeczeństwa ideałem życiowym było spokojne życie, bez większej aktywności, czyli wegetacja, przy ograniczeniu potrzeb do minimum. Tym tłumaczy się niska wydajność. Większość pracodawców traktuje swoje warsztaty „jako nabyte prawo do wygodnej egzystencji o wyższym od innych poziomie potrzeb bez konieczności codziennej systematycznej pracy"228. Grabski opowiadał się za wprowadzeniem ostrych reguł $w$ pracy, zwłaszcza w sferach

ugruntowane podstawy tego rozwoju, jakie zostały zdobyte stałe i nowe placówki, będące punktem wyjścia dalszego rozwoju, w jakiej mierze zostały opanowane trudności hamujące rozwój, lub w jakiej mierze ujawniły się nowe niebezpieczeństwa, to w tych licznych zestawieniach cyfrowych i wykresach graficznych nie znajdziemy wcale tego, coby nam dało oświetlenie i odpowiedź na najważniejsze pytania, tyczące się istoty rozwoju gospodarczego" (ibidem, s. 19-20).

${ }^{226}$ „Badanie przeszłości nagromadziło wiele takich zagadnień rozwojowych, które badacze starali się wyświetlić. Rozwój komunikacyj morskich i założenie licznych placówek ekspansji kolonjalnej, nie podniosło w swoim czasie Portugalii na wyższy szczebel rozwoju, pomimo dogodniejszego położenia i wielkich powodzeń na polu odkryć i zdobyczy nowych terenów, a natomiast odegrało wielką rolę dodatnią w rozwoju gospodarczym Holandji. Wskazuje to, że dla ciągłości rozwoju gospodarczego nie wystarczy, by działały pewne sprzyjające czynniki ogólne, które, będąc zasadniczo korzystnemi, stanowią w jednym wypadku tło jedynie dla szeregu okresów korzystnej konjunktury (Portugalja), w drugim dają podstawę do trwałego rozwoju (Holandja). Takich faktów w dziejach mamy niezliczone przykłady. Wytworzenie się potęgi gospodarczej Prus i Niemiec było przedmiotem wielu studjów historyczno-rozwojowych. Objaśnić utworzenie się tej potęgi samemi warunkami materjalnemi nie sposób. W wielu bardzo wypadkach przyjazne konjunktury nie zabezpieczają trwałego i silnego rozwoju gospodarczego w innych odwrotnie, rozwój gospodarczy toruje sobie drogę poprzez szereg nieprzyjaznych okoliczności, deprymująco oddziaływujących na konjunkturę" (ibidem).

227 Ibidem, s. 23.

${ }^{228}$ W. Grabski, Dwa lata pracy..., s. 346. 
kierujących życiem publicznym. Radził usuwać ludzi nieprzydatnych i nie przejmować się tym, że mówią o takim człowieku, że jest bez serca. Kto nie zwalnia pracownika nieudolnego, ten działa na szkodę Ojczyzny ${ }^{229}$.

W. Grabski, skoncentrowany na problematyce agrarnej, zalecał wzmożenie prac w całej gospodarce narodowej: „Dorównać kulturze materialnej Zachodu, to nakaz dla nas życia i śmierci. Nakaz ten stosuje się zarówno do miast, jak i wsi" ${ }^{230}$.

\section{Inflacja}

W. Grabski określał inflację jako spadek wartości pieniądza, spowodowany drukiem banknotów bez odpowiedniego pokrycia. Poznał on dobrze naturę inflacji, walcząc z nią jako minister skarbu, a następnie, jako premier i minister skarbu.

Nadmierną emisję pieniądza powodował wzrost wydatków państwowych. Grabski podaje dwa źródła wzrostu wydatków publicznych:

1. Powojenna odbudowa infrastruktury kraju (koleje, drogi, mosty), koszty związane z likwidacją skutków zaborów (administracja, oświata, sądownictwo), wydatki na emerytury nie tylko obywateli pracujących w Polsce, lecz także na terenie państw zaborczych.

2. Obciążenia skarbu państwa $\mathrm{z}$ tytułu zwiększonych wydatków na ubezpieczenia społeczne (nowe ustawodawstwo socjalne, opieka społeczna, zwłaszcza koszty utrzymania wdów i sierot po poległych żołnierzach ${ }^{231}$.

W. Grabski wyróżniał inflację wojenną i powojenną. Wypuszczenie nadmiernej ilości banknotów w czasie wojny jest koniecznością ze względu na ogromne wydatki na zbrojenia, aprowizację i działania wojenne. Zaznaczał jednak, że ma ona stosunkowo nieznaczny wpływ na wartość pieniądza, gdyż przy znacznie zmniejszonych obrotach handlowych z zagranicą waluta jest głównie środkiem płatniczym wewnątrz kraju.

Zwracał baczną uwagę na skutki inflacji. Inflacja umiarkowana jest „mało szkodliwa". W czasie jej trwania pojawiają się nawet efekty pozytywne. Wraz ze wzrostem cen rosną zyski producentów oraz zwiększa się popyt na kredyty inwestycyjne. Duże korzyści uzyskują rolnicy ze sprzedaży produktów rolnych.

\footnotetext{
${ }^{229}$ Ibidem, s. 347.

${ }^{230}$ W. Grabski, Przeludnienie wsi..., s. 302.

${ }^{231}$ W. Grabski, Polityka ekonomiczna ..., s. 9.
} 
Inflacja nadmierna prowadzi do hiperinflacji, która pociąga za sobą poważne zaburzenia w funkcjonowaniu całej gospodarki. Spadek wartości pieniądza powoduje niepokój na rynkach finansowych, który łatwo może się przerodzić w panikę. Podwyżki płac pracowniczych i robotniczych kończą się wprowadzeniem płac ruchomych, opartych na wskaźniku drożyźnianym. W produkcji nie ma wiarygodnych podstaw do kalkulacji, a podatki są nader niskie. We wszystkich niemal dziedzinach życia gospodarczego panuje chaos i destabilizacja ${ }^{232}$.

Hiperinflacja jest bardzo niekorzystna dla rolnictwa. Podjęta przez państwo reglamentacja cen najsilniej dotyka produkty rolne, co uniemożliwia producentom rolnym osiąganie odpowiednich dochodów, gdyż ceny kształtują się często poniżej kosztów produkcji. Wysoka inflacja prowadzi do zjawiska tzw. nożyc cen. Wówczas ceny na towary przemysłowe rosną dużo szybciej niż ceny artykułów rolnych ${ }^{233}$.

W. Grabski przykładał dużą wagę do zwalczania głównego źródła inflacji, jakim były nadmierne wydatki państwowe. Ażeby osiągnąć ten cel, decydował się na niepopularne decyzje. Szukał oszczędności w ograniczaniu wydatków na administrację, fundusze socjalne, a po zakończeniu wojny z bolszewikami - na zbrojenia i wojsko. Proponował też zmniejszenie liczby świąt, ale Sejm nie wyraził na to zgody ${ }^{234}$. Istotną rolę $w$ utrzymaniu stabilnej waluty miał pełnić bank centralny, mający uruchamiać w razie potrzeby rezerwę walutową.

$\mathrm{W}$ walce $\mathrm{z}$ inflacją doceniał Grabski znaczenie efektu psychologicznego. Kierując się tym czynnikiem zdecydował się na jednoczesne działania, mające na celu zrównoważenie budżetu i sanację waluty polskiej. Słusznie przewidywał, że pozytywne efekty w jednej dziedzinie wpłyną dodatnio na reformowanie drugiej sfery. Jeszcze większą skuteczność miało wykorzystanie czynnika psychologicznego w ograniczeniu spekulacji na giełdzie warszawskiej. Dnia 13.01.1924 r. Grabski podjął pokerową decyzję dotyczącą interwencji giełdowej. Rozpoczęto wówczas sprzedaż dolarów po obniżonym kursie. Posiadacze dużych zasobów dolarowych, nastawieni na dalszą zwyżkę kursu (liczyli, że w końcu stycznia osiągnie on $20 \mathrm{mln}$ marek za dolara), wpadli w panikę. Uświadomili sobie, że przy spadku kursu dolara mogą być zagrożone płatności markowe. Zaczęli więc w popłochu sprzedawać dolary. Do banku centralnego (PKKP) napływały masowo dewizy (30 mln dol. w ciągu kilku tygodni). Marka polska zaczęła stopniowo wykazywać oznaki stabilizacji" ${ }^{235}$.

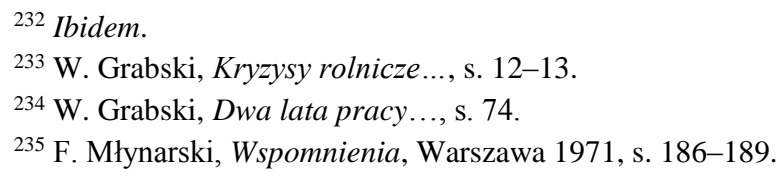


Wprowadzenie nowej waluty - złotego i nowej instytucji - Banku Polskiego było również trafnym pociągnięciem, spowodowało bowiem wzrost zaufania społeczeństwa do rządu i gospodarki polskiej.

Poglądy makroekonomiczne Władysława Grabskiego były osadzone na solidnej bazie źródłowej i bogatym doświadczeniu praktycznym. Nie były oderwane od rzeczywistości, stąd też miały walory prakseologiczne. Nie zawsze pokrywały się z założeniami koncepcyjno-teoretycznymi, na co starałem się zwracać uwagę, ale uwzględniały konkretne sytuacje gospodarcze oraz możliwości stosowania środków zaradczych ${ }^{236}$.

${ }^{236}$ Por. J. Luszniewicz, Wahania koniunktury a geneza, rozwój i kryzys keynesizmu. Refleksje historyczno-gospodarcze, [w:] Koniunktura gospodarcza a narodziny, wzrost $i$ upadek wielkich doktryn ekonomicznych. Księga pamiątkowa w 50-lecie śmierci profesora Andrzeja Grodka, red. J. Łazor, W. Morawski, Warszawa 2011, s. 73-98. 



\section{Rozdzial III}

\section{Polityka ekonomiczna}

\section{Przedmiot polityki ekonomicznej}

Władysław Grabski szczególne miejsce w naukach ekonomicznych wyznaczał polityce ekonomicznej. Prowadził badania pod kątem potrzeb polityki ekonomicznej państwa. Poszukiwał rozwiązań praktycznych, analizując całościowo życie gospodarcze kraju. Opierał się na teraźniejszości i ostatnich latach przeszłości. Umożliwiało to zestawianie faktów $\mathrm{z}$ ich bezpośrednimi skutkami i na tej podstawie pozwalało formułować wskazówki do właściwego postępowania. Jej przedmiot definiował następująco: „Polityka ekonomiczna jest nauką o sposobach osiągnięcia i zachowania dobrobytu"1.

Aby zrealizować ten cel, „Na czoło programu gospodarczego Państwa postawić należy takie zorganizowanie życia gospodarczego, by wszystkie naturalne warunki w granicach Państwa naszego istniejące, zostały wykorzystane w sposób najbardziej skuteczny dla zabezpieczenia maximum dobrobytu powszechnego. W związku z tem staje się koniecznem, by w pracy wytwórczej znaleźć mogła udział cała ludność, jaką posiadamy. Wymaga to, byśmy nie sprowadzali tego, co sami wytwarzać możemy, dopóki istnieją u nas masy nie mogące w kraju znaleźć zatrudnienia. Oparcie konsumpcji na krajowej produkcji musi być najistotniejszym celem naszej polityki gospodarczej"2.

W. Grabski pisał, że nie można utożsamiać polityki ekonomicznej z ekonomią społeczną. Zakres ekonomii społecznej jest szerszy, obejmuje m.in. politykę gospodarczą i pozwala ustalić pewne normy dla zjawisk ekonomiczno-społecznych. Ponadto posługuje się odrębnymi metodami badań ${ }^{3}$.

${ }^{1}$ W. Grabski, Polityka ekonomiczna. Skrypt z wykladów Prof. Władysława Grabskiego, Warszawa 1938, s. 1.

${ }^{2}$ W. Grabski, Program walki z kryzysem w Polsce, Warszawa 1925, s. 41.

${ }^{3}$ W. Grabski, Polityka ekonomiczna ..., s. 1. 
Interesy poszczególnych warstw społecznych, różne, a często i sprzeczne, kształtują wielorakie kierunki polityki ekonomicznej. W. Grabski wyodrębnił pięć takich kierunków: 1) proprodukcyjny i prokonsumpcyjny, 2) wierzycielski i dłużniczy, 3) prokapitalistyczny i prorobotniczy, 4) liberalny i etatystyczny, 5) narodowy i światowy ${ }^{4}$.

Polityka proprodukcyjna wspomaga interesy producenta, dążącego do uzyskania maksymalnych zysków. Natomiast celem polityki prokonsumpcyjnej jest zaspokojenie maksymalnych potrzeb (za pomocą posiadanych środków) pracowników mających stałe dochody. Często polityka prokonsumpcyjna łączy się z polityką proprodukcyjną, co bardzo wyraźnie godzi w interesy rolnictwa.

W polityce wierzycielskiej i dłużniczej wierzyciel jest zainteresowany polityką prokonsumpcyjną, a producent funkcjonuje zasadniczo w oparciu o kredyt.

Polityka prokapitalistyczna polega na wzroście wytwórczości, dąży do równowagi między dłużnikiem i wierzycielem oraz zapewnia swobodny obrót bez regulacji cen. Koniecznym warunkiem w jej realizacji jest odpowiednia ochrona własności prywatnej. Polityka prorobotnicza chroni interesy robotnika, wspierając ustawodawstwo robotnicze oraz nasilając presję na ograniczanie cen towarów.

W myśl zasad polityki liberalnej, każdy obywatel ma prawo do własności prywatnej oraz pełną swobodę do jej uzyskania. Grabski zaznaczał, że w praktyce jest to właściwie nieosiągalne, a w wypadku pojawienia się poważnych trudności gospodarczych - szkodliwe, gdyż pozostawia obywateli wyłącznie ich własnym środkom. Kierunek etatystyczny oznacza opiekę państwa nad społeczeństwem.

Polityka światowa opiera się na doktrynie liberalnej i służy zniesieniu barier celnych oraz wszelkich ograniczeń w zakresie ilości i rodzajów produkcji w poszczególnych państwach. Celem polityki narodowej jest osiągnięcie maksymalnego dobrobytu własnego społeczeństwa ${ }^{5}$.

W. Grabski, niezależnie od klasyfikacji polityki ekonomicznej na podstawie kryterium funkcjonalnego, dokonał jej podziału uwzględniając poszczególne działy gospodarki, politykę agrarną, skarbową, celną, finansową, kredytową i walutową. Podział ten w istocie rzeczy znalazł potwierdzenie w jego twórczości i działalności publicznej. Realizacja poszczególnych rodzajów polityki była uzależniona od sytuacji ekonomiczno-społecznej kraju i zmian w strukturze gospodarki polskiej.

\footnotetext{
${ }^{4}$ Ibidem, s. $1-2$.

${ }^{5}$ Ibidem.
} 


\section{Kierunki rozwoju gospodarki polskiej}

W pierwszym dziesięcioleciu odrodzonego państwa polskiego wyrażano przekonanie, że Polska powinna rozwijać się jako kraj rolniczy, bądź też rolniczo-przemysłowy ${ }^{6}$. Dopiero w końcu lat 20 . i w latach 30 . pojawiły się jednoznaczne opinie o konieczności uprzemysłowienia kraju?

W. Grabski należał do tej grupy ekonomistów, którzy w koncepcjach swych wychodzili z założenia, że Polska jest krajem rolniczo-przemysłowym i fakt ten wyznaczał przyszłą strukturę gospodarki polskiej. Pisał, że Polska „nie może być państwem agrarnym w tym znaczeniu, żeby lekceważyła rozwój przemysłu... nie może być antagonizmu między rozwojem produkcji rolnej i przemysłowej"s.

Obydwa te główne działy winny - zdaniem Grabskiego - rozwijać się równomiernie. Aby sprostać temu zadaniu, należało stworzyć jednakowe warunki, tak dla rozwoju przemysłu, jak i rolnictwa ${ }^{9}$. W programie gospodarczym zalecał przyciąganie kapitału inwestycyjnego krajowego i zagranicznego, który umożliwiłby rozwój istniejących oraz tworzenie nowych przedsiębiorstw. Powinno się zapewnić - według niego - ustawowe ulgi dla inwestorów i koncesje dotyczące posiadania terenów budowlanych i eksploatacyjnych ${ }^{10}$.

W. Grabski uważał, że rozwój przemysłu w Polsce jest koniecznością, wynikającą z dotychczasowej struktury rolniczo-przemysłowej, a szczególnie $\mathrm{z}$ istniejącego na wsi przeludnienia agrarnego. Likwidacja tego zjawiska wymuszała niejako podjęcie decyzji o rozwoju przemysłu: „bo mamy tak gęstą ludność i takie położenie geograficzne, że na to pozwolić sobie nie możemy.

${ }^{6}$ Potwierdzają to opinie zawarte w pracach nagrodzonych w konkursie Banku Krajowego nt. programu gospodarczego Polski. B. Balukiewicz i J. Piekałkiewicz postulowali oparcie rozwoju o leśnictwo. S. Rosciszewski jedyną szansę dla gospodarki polskiej widział w rolnictwie. Tę samą opinię wyrażali: W. Grabiański, W. Diamant i R. Battaglia. Na sześciu nagrodzonych autorów tylko jeden - F. Zweig proponował intensywny rozwój przemysłu, lecz i on nie potrafił wyzwolić się z wizji Polski, jako kraju rolniczo-przemysłowego. „Polska jest krajem rolniczo-przemysłowym i musi nim pozostać" (W. J. Puliński, Poglady agrarne Władysława Grabskiego. Praca doktorska, Łódź 1979, Biblioteka Uniwersytetu Łódzkiego, s. 195).

${ }^{7}$ Pogląd ten lansował m.in. E. Kwiatkowski, Rekonstrukcja gospodarcza Polski, Warszawa 1929 i W. Styś, Rolnictwo a uprzemysłowienie, Lwów 1938.

${ }^{8}$ W. Grabski, Rzad wobec kryzysu gospodarczego, Warszawa 1925, s. 28. Zob. też: idem, Wewnętrzny rynek zbytu, ,Rolnik Ekonomista” 1933, nr 21.

${ }^{9}$ W. Grabski, Dwa lata pracy u podstaw państwowości naszej (1924-1925), Warszawa 1927, s. 336; idem, Rzad wobec kryzysu ..., s. 28.

${ }^{10} \mathrm{~W}$. Grabski, Projekt programu polityki ekonomicznej i finansowej Polski po wojnie, Warszawa 1920, s. 13. 
Tylko państwo o rzadkim zaludnieniu mogłoby pozwolić sobie na lekceważenie czynnika rozwoju przemysłowego" 11 . Grabski nie proponował zmiany struktury gospodarczej Polski, ale jedynie jej modyfikację.

W latach 1918-1926 elity polityczne i ekonomiści poważnie rozważali dylemat: „Polska agrarna czy przemysłowa?” Proponowano wówczas zachowanie równowagi między obu potencjalnymi opcjami. W 1926 r. rząd - po uwzględnieniu zaleceń misji Edwina W. Kemmerera - przyjął program, który zapowiadał wzmożenie produkcji rolniczej i wykorzystanie bogactw naturalnych oraz popieranie przemysłu fabrycznego $\mathrm{w}$ granicach potrzeb rynku wewnętrznego. Kurs na uprzemysłowienie obrano dopiero od 1936 r., głównie za sprawą wicepremiera Eugeniusza Kwiatkowskiego ${ }^{12}$.

W. Grabski pragnął przyspieszenia rozwoju przemysłu drobnego w oparciu o zasoby wsi, miejscową siłę roboczą i surowce rolnicze. Zdawał sobie jednak sprawę, że przemysł rolny połączony z gospodarstwem rolnym „ma tę ujemną właściwość ekonomiczną", że jest to przemysł średniego typu. Rolnictwo potrzebowało przemysłu na wielką skalę ${ }^{13}$. Warunkiem rozwoju takiego przemysłu było podniesienie poziomu życia kulturalnego wsi ${ }^{14}$.

Grabski negatywnie oceniał skuteczność polityki gospodarczej w Polsce w latach 1918-1936. Pisał, że mimo wysiłków brak było efektów, które uprawniałyby do stwierdzenia, że obrano drogę najwłaściwszą. Przeciwnie, w niektórych dziedzinach (reforma rolna, podniesienie poziomu życia ludności, oświaty itp.) cel oddalał się, zamiast przybliżać ${ }^{15}$.

Ocena Grabskiego polityki rządowej wydaje się być zbyt surowa. Reforma rolna i parcelacja była realizowana, wprawdzie $\mathrm{z}$ różnym powodzeniem, $\mathrm{w}$ całym okresie międzywojennym. W jej wyniku chłopi otrzymali około $3 \mathrm{mln}$ ha ziemi. Własność chłopska powiększyła się o 13\%, zaś powierzchnia majątków obszarniczych zmniejszyła się o $16 \%{ }^{16}$.

${ }^{11}$ W. Grabski, Rząd wobec kryzysu..., s. 28-29.

${ }^{12}$ Z. Landau, W. Roszkowski, Polityka gospodarcza II RP i PRL, Warszawa 1995, s. 23-24; J. Luszniewicz, Druga Rzeczpospolita. Wzrost podporzadkowany integracji i modernizacji gospodarczej, [w:] Polskie osiagnięcia gospodarcze, red. J. Kaliński, Warszawa 2010, s. 149.

${ }^{13}$ W. Grabski, Cele i zadania polityki agrarnej w Polsce, Warszawa 1918, s. 37.

14 „Na dalszą metę najbardziej solidny środek uprzemysłowienia kraju całego, to rozbudzenie wsi do życia kulturalnego i wytworzenie atmosfery do życia takiej, w której energia życiowa samych wieśniaków zdolna byłaby tworzyć własne rzemiosło, handel i przemysł, tak, jak widzieliśmy to w wielu krajach innych...” (W. Grabski, Wieś jako siła spoleczna, „Rolnictwo” 1936, t. II, z. 2).

${ }^{15}$ W. Grabski, System socjologii wsi, cz. II, „Roczniki Socjologii Wsi”, t. II, 1937, s. 5.

${ }^{16}$ M. Mieszczankowski, Struktura agrarna Polski międzywojennej, Warszawa 1960. 
Położenie materialne chłopów pogorszyło się w porównaniu z okresem przed odzyskaniem niepodległości. Korzystniej przedstawiała się sytuacja klasy robotniczej. W niektórych grupach zatrudnionych wzrosły, w porównaniu ze stanem przedwojennym, płace realne. Podwyżka wynagrodzenia objęła przede wszystkim robotników wykwalifikowanych. Dobrze zarabiali ludzie wykształceni, zawodowi wojskowi i policja ${ }^{17}$.

Nie można też zgodzić się z Grabskim, gdy mówi o braku postępu w dziedzinie oświaty, nastąpił bowiem wyraźny rozwój szkolnictwa powszechnego. Liczba uczniów wzrosła z około 3,2 mln w 1922/1923 r. do prawie $5 \mathrm{mln}$ w 1938/1939 r. Odsetek analfabetów obniżył się z 33,1\% w 1921 r. do 23,1\% w 1931 r. i około $15 \%$ w 1939 r. ${ }^{18}$

\section{Polityka finansowa}

W. Grabski wiele uwagi poświęcał problematyce rolnej (zob. rozdz. II). W rozdziale czwartym zostaną omówione jego poglądy agrarne. Grabski traktował rolnictwo jako podstawę polskiej gospodarki. Trudna sytuacja ekonomicznospołeczna kraju w okresie międzywojennym wymuszała jednak, aby koncentrować się na rozwiązywaniu bieżących problemów. Dlatego też w polityce ekonomicznej czołowe miejsce zajmowała polityka finansowa i walutowo-kredytowa.

W. Grabski uważał, że głównym celem polityki ekonomicznej państwa, jest przeciwdziałanie inflacji, osiągnięcie równowagi budżetowej, podniesienie produkcji krajowej i zrównoważenie produkcji z konsumpcją oraz zbilansowanie eksportu z importem ${ }^{19}$. Natomiast podstawą prawidłowej polityki skarbowej powinna być równowaga pomiędzy wydatkami a dochodami, przy równoczesnym zaspokojeniu niezbędnych potrzeb państwa. Najprostszym sposobem osiągnięcia równowagi budżetowej było - według niego - ograniczenie wydatków i podniesienie dochodów, a różnicę między wydatkami i dochodami należało pokrywać zaciąganiem pożyczek krajowych i zagranicznych ${ }^{20}$.

Odrodzona Polska wymagała ogromnych wydatków: na odbudowę zniszczeń wojennych, przezwyciężenie skutków wieloletniej niewoli i wojnę $\mathrm{z}$ bolszewikami. Pojawiło się cały szereg nowych wydatków, m.in. na szkolnictwo wyższe, świadczenia Ministerstwa Pracy, roboty publiczne, zagospodarowywanie

${ }^{17}$ J. Skodlarski, Zarys historii gospodarczej Polski, Warszawa 2000, s. 316.

${ }^{18}$ Maty rocznik statystyczny 1939, s. 317; A. Albert, Najnowsza historia Polski, 1918-1980, Polonia 1989, s. 281.

${ }^{19}$ W. Grabski, Projekt programu polityki..., s. 17.

${ }^{20}$ Ibidem, s. $18-19$. 
odłogów, infrastrukturę (koleje, drogi, kanały). Grabski wskazywał, że realizację tych przedsięwzięć rozpoczęto nim nastąpił napływ pieniędzy $\mathrm{z}$ nowych podatków ${ }^{21}$.

Kraj miał ogromne potrzeby. Aby im podołać, społeczeństwo musiało zdobyć się na nadzwyczajny wysiłek. Grabski przekonywał, że pieniądze muszą być przeznaczane na „rzeczy konieczne”. Niezbędne wydatki, zresztą ograniczone, przyznawano sferze budżetowej, zaś nadzwyczajne - na armię i pomoc socjalną (pierwsze lata powojenne). Po zakończeniu wojny polsko-bolszewickiej Grabski proponował zmniejszenie wydatków na wojsko, a w okresie poprawy koniunktury - na cele socjalne. Konsekwentnie wypowiadał się za ograniczeniem wydatków osobowych i rzeczowych podwyższanych przez władze centralne, tj. na funkcjonowanie rządu, sejmu kancelarii prezydenta oraz na ministerstwa. Twierdził, że ministerstwa wykazują, z jednej strony, małą aktywność w pozyskiwaniu nowych źródeł dochodów, a z drugiej - nie rezygnują z finansowania „bezczynnych” urzędów. Uważano powszechnie, że przyznany kredyt trzeba koniecznie wykorzystać. Grabski ubolewał, że w Polsce zakorzenione jest postrzeganie skarbu państwa, jako „dojnej krowy”, z której każdy winien korzystać ${ }^{22}$.

Premier był przeciwny udzielaniu subwencji przedsiębiorstwom i budżetom lokalnym. Finansowanie samorządów należało opierać na własnych źródłach dochodów. Skarb nie powinien łożyć na inwestycje przemysłowe. Wyjątek mogły stanowić obiekty o znaczeniu strategicznym dla państwa, np. zakłady zbrojeniowe, budowa portu w Gdyni. Ulgi podatkowe należało przyznawać tylko wyjątkowo, po zbadaniu konkretnych przypadków ${ }^{23}$.

Wnioski dotyczące wydatków musiały zawierać źródła ich pokrycia. „Jeżeli kto, czy w Sejmie, czy w Rządzie, proponuje nowy wydatek, jeżeli zapada decyzja podwyżki, to zawsze powinno być powiedziane, z jakich to środków będą pokryte te wydatki. Jeżeli to nie jest powiedziane, jest to nieuczciwem, bo ogół społeczeństwa może myśleć, że te dobrodziejstwa i ustępstwa są czynione z tych źródeł, jaki społeczeństwo i Rząd posiadają. Jeżeli zatem uchwalony jest wydatek bez oznaczeń źródła dochodu do jego pokrycia, powinno być przynajmniej w imię prawdy powiedziane, że pokrycie danego wydatku powierza się drukarni pieniędzy papierowych"24.

Grabski powoływał się na praktykę stosowaną w niektórych krajach europejskich. W Czechosłowacji i Hiszpanii przyjęto zasadę, że nie wolno

\footnotetext{
${ }^{21}$ Ibidem, s. 28.

${ }^{22}$ Ibidem, s. 9 i 21.

${ }^{23}$ Ibidem, s. 7, 9 i 31.

${ }^{24}$ Ibidem, s. 21.
} 
projektować wydatków bez wskazania źródła dochodów. W Niemczech bez zgody ministra skarbu żaden wydatek nie mógł być uchwalony przez radę ministrów. Grabski uważał za słuszne, aby wydatki zwyczajne państwa były pokrywane z dochodów zwyczajnych, a nadzwyczajne - z pożyczek. Zasada ta była respektowana w większości krajów europejskich ${ }^{25}$.

W. Grabski zdawał sobie sprawę, że stan skarbu państwa zależy przede wszystkim od podatków płaconych przez sfery posiadające. Lata niewoli sprawiły, że utrwalił się w społeczeństwie niechętny stosunek do realizacji zobowiązań finansowych na rzecz państwa. Grabski na tę kwestię był szczególnie wyczulony: „O tem, że szerokie sfery warstw posiadających pozbawione są u nas podstaw etyki podatkowej tej etyki, która stanowi siłę współczesnych demokracji wspominałem już parokrotnie. Dziwić się temu trudno wobec tego, że w okresie zaborów taka etyka w ogóle nie mogła się przecież rozwijać. A i obecnie mamy również wśród sfer posiadających tak znaczny odłam ludności, której stosunek do państwa nie jest pozytywny a tylko albo negatywny albo neutralny, że na wyrobienie w tej sprawie etyki podatkowej rządowi jest bardzo trudno. A chyba ta etyka ma to do siebie, że albo jest powszechną, albo jej nie ma wcale za małymi wyjątkami, bo życie ekonomiczne oparte jest na konkurencji i jeden ogląda się na drugiego, gdy idzie o to wiele i za co płaci. Brak etyki podatkowej społeczeństwa będzie długo jeszcze u nas hamulcem w doskonaleniu naszego aparatu skarbowego i w wytworzeniu naszej siły skarbowej. Wiele zła dla naszego życia gospodarczego wynika z [...] braku skrupulatności w wywiązywaniu się z zobowiązań pieniężnych" ${ }^{26}$.

Rolnicy polscy, podobnie jak producenci rolni w innych krajach, narzekali na wysokie podatki. W. Grabski podkreślał, że „U nas mówi się o potrzebie powiększenia tych ciężarów dla ulżenia miastom. Istotnie ciężary najdrobniejszych rolników są nieznaczne, ale rolnicy średni i więksi mają obciążenia poważne. Obniżenie jednak tych ciężarów napotyka na wielkie trudności"27.

W. Grabski, czyniąc uwagi dotyczące budżetu na 1926 r., zwrócił uwagę na drastyczne zmniejszenie podatków „,z danin”. Podczas, gdy w 1924 r. dochody z „danin” wynosiły 70\% ogółu dochodów budżetowych, to w 1926 r. spadły one do 53\%. Ten sam stosunek zapisano w budżecie na rok 1927. Grabski nie zalecał jednak podwyższania stopy podatków. Uznał, że sprawa dojrzała do przeprowadzenia gruntownej reformy podatkowej. Chodziło przede wszystkim o usunięcie rażących dysproporcji w płaceniu podatków. Przeciwstawiał się ograniczaniu

${ }^{25}$ Ibidem, s. 20.

${ }^{26}$ Archiwum Akt Nowych, Akta Władysława Grabskiego, sygn. III-9, j. 1, k. 285. Brulion pracy W. Grabskiego, Dwa lata pracy u podstaw państwowości naszej (1924-1925), Warszawa 1927.

${ }^{27}$ W. Grabski, Kryzys rolniczy, Warszawa 1925, s. 28. 
wydatków budżetowych na wojsko i oświatę. W 1926 r. wyniosło ono 85\% całej redukcji wydatków. Oszczędności te zagrażały obronności oraz perspektywie rozwoju kraju. Uważał też za niesprawiedliwe, aby kosztem płac pracowników państwowych (poniżej określonego minimum) podnoszono wydatki na świadczenia społeczne ${ }^{28}$.

W 1933 r., nie bacząc na zastrzeżenia Grabskiego, zlikwidowano podatek majątkowy. Zastąpiono go nadzwyczajną daniną majątkową, która do $1937 \mathrm{r}$. obciążała płatników podatku gruntowego, obrotowego i od nieruchomości. W 1937-1938 r. podatek z daniny majątkowej przysporzył 2 mln zł, a w $1939 \mathrm{r}$. pobór ostatecznie wygas ${ }^{29}$.

Dość dużo dochodów dostarczały monopole skarbowe. W. Grabski zalecał ostrożną politykę wobec monopoli, obawiając się, że ich nadmierny rozwój będzie wzmacniał etatyzm w Polsce. Monopole powinny mieć wyraźnie charakter fiskalny ${ }^{30}$. Z jego inicjatywy sejm przyjął ustawę dotyczącą rozwiniętego monopolu tytoniowego. W latach 1934-1938 roczne jego dochody przekraczały $500 \mathrm{mln}$ zł (największe wśród wszystkich monopoli skarbowych) ${ }^{31}$.

W. Grabski, poszukując źródeł zwiększenia dochodów państwowych, wskazywał na racjonalizację eksploatacji lasów rządowych. Proponował nadać zarządom leśnym uprawnienia umożliwiające prowadzenie przedsiębiorstw. Zalecał przekazywanie na dłuższy okres eksploatacji większych terenów leśnych osobnym firmom prywatnym lub spółkom krajowym bądź zagranicznym pod warunkiem przeprowadzenia niezbędnych inwestycji ${ }^{32}$.

$\mathrm{W}$ tej kwestii kolejne rządy w latach 30 . postępowały zgodnie $\mathrm{z}$ sugestią Grabskiego. Sprzedaż roczna drewna z lasów państwowych wzrosła z $8,3 \mathrm{mln} \mathrm{m}^{3}$ w 1930-1931 r. do 10,4 mln m³ w 1937-1938 r. Godne podkreślenia jest to, że nie odbywało się to kosztem rabunkowej eksploatacji lasów. W okresie 1930-1938 roczny wyrąb utrzymywał się na poziomie około 23 tys. ha, a zalesienie obejmowało około 40 tys. ha ${ }^{33}$. s. 3-6.

${ }^{28}$ W. Grabski, Równowaga budżetu i konieczności państwowe, „Drogi Naprawy” 1927, nr 6,

${ }^{29}$ Maty rocznik statystyczny 1939, s. 380; Z. Landau, Podatek majątkowy, [w:] Encyklopedia historii gospodarczej Polski do 1945 roku, Warszawa 1981, s. 89.

${ }^{30}$ „W zakresie tworzenia monopolów skarbowych mających na celu zwiększenie środków dochodów w Polsce, nie powinno się iść zbyt daleko, aby nie wzmacniać przez to sztucznie i niepotrzebnie ogólnego systemu w dziedzinie gospodarczej. Z tego jednak nie należy wnosić, iż należy się wyrzec wprowadzenia monopolów skarbowych w tych dziedzinach, w których da się osiągnąc tą drogą poważniejszy dochód" (W. Grabski, Projekt programu..., s. 30).

${ }^{31}$ Maty rocznik statystyczny 1939, s. 389.

${ }^{32}$ W. Grabski, Projekt programu..., s. 9.

${ }^{33}$ Maty rocznik statystyczny 1939, s. 89. 
W. Grabski wielokrotnie zwracał uwagę na trudności, które towarzyszyły ściąganiu podatków. Był realistą i wiedział, że nie można oczekiwać od społeczeństwa, aby chętnie płaciło z własnej kieszeni. W żadnym państwie nie znajdzie się entuzjastów przymusowych świadczeń. Jednakże w Polsce psychoza antypodatkowa ugruntowała się nadzwyczaj mocno. Jakie przyczyny doprowadziły do tego stanu rzeczy? Niewątpliwy wpływ wywarły ,złe przyzwyczajenia przeszłości”. Grabski wskazywał jeszcze inne ważne przyczyny, a mianowicie demoralizację państwowej służby podatkowej, a zwłaszcza negatywne skutki nieuczciwej działalności urzędników ${ }^{34}$. Apelował o uzdrowienie aparatu podatkowego, wyszukiwanie ludzi uczciwych i wzbudzających zaufanie społeczeństwa. Był przekonany, że ich działalność nie może przynieść efektów, jeśli właściciele i producenci nie będą uczciwi w zeznaniach i szacowaniu dochodów i obrotu gospodarczego ${ }^{35}$.

Mimo różnorodnych inicjatyw, możliwości powiększania dochodów skarbowych były dość ograniczone. W tej sytuacji rząd musiał poszukiwać oszczędności. W. Grabski dążył do racjonalizacji wydatków. Gdy minęło zagrożenie bolszewickie, doprowadził do zmniejszenia budżetu Ministerstwa Spraw Wojskowych ${ }^{36}$. W następnych latach, kiedy rząd dokonał nadmiernych cięć w nakładach na wojsko i oświatę, uznał te decyzje za wielce niekorzystne dla przyszłości państwa polskiego.

Grabski był szczególnie wyczulony na marnotrawstwo pieniędzy publicznych. Przemawiając w Sejmie w 1925 r. zapowiedział utworzenie w każdym

${ }^{34}$ „Nic tak nie demoralizuje podatników jak to, gdy prawdzie nie daje się wiary, gdy samowolnie i bez podstaw wmawia się w kogoś, że miał więcej dochodu lub obrotu, niż miał istotnie. Gdy kto raz zmuszony zostanie zapłacić więcej, niż należy, już on sam więcej prawdą kierować się nie będzie, a dziesięć innych osób rozgrzeszy się też w swoim sumieniu, widząc, że takiego który chciał być sprawiedliwy, spotkała krzywda. O takich krzywdach ciągle się słyszy. Czyżby to robili ludzie złośliwi? Nie, robią to ludzie zwykli. Nie znają oni swego społeczeństwa. A przede wszystkim są zgorzkniali, zmuszeni do pracowania za zbyt marne wynagrodzenie, są zgnębieni biedą i nieufni. Nie wiedzą oni, komu wierzyć, komu nie, wolą nie wierzyć nikomu... Taka psychika jest nędzna i marna, bo jest to bronienie samego siebie i swoich bliźnich przed potrzebami Polski. Złe ustawy do wytworzenia takiej psychiki się przyczyniają. Ci z urzędników, którzy są bądź nie dość inteligentni, bądź złośliwie do całego społeczeństwa usposobieni, do wytworzenia się tej psychiki swoim postępowaniem się przyczyniają. Ale przecież ci większości nie stanowią. Większość urzędników ma te same wady i charaktery co i ogół społeczeństwa. Tak samo i w ustawach naszych, obok niektórych wad jest bardzo dużo słusznych i mądrych rzeczy, zaczerpniętych z doświadczeń i wzorów państw zachodnich” (W. Grabski, Dwa lata pracy..., s. 335 i 394).

${ }^{35}$ Ibidem.

${ }^{36}$ Po zakończeniu wojny postanowiono zmniejszać budżet w granicach 15-17 mld marek rocznie (W. Grabski, Projekt programu..., s. 23). 
ministerstwie instytutu kontrolerów budżetu. Wzorem miał być instytut zorganizowany we Francji. Przygotowano zastosowanie środków ograniczających wydatki w całej administracji, samorządach i innych organach prawno-publicznych ${ }^{37}$. Urzędom zakazano nabywania luksusowych urządzeń i przedmiotów ${ }^{38}$.

\section{Polityka walutowo-kredytowa}

W. Grabski już od 1919 r., jako minister skarbu, dążył do podniesienia wartości pieniądza (wówczas marki polskiej). Obniżanie się wartości siły nabywczej waluty uważał za największe zło, ponieważ prowadziło to do wzrostu drożyzny. Narastająca inflacja „podkopywała byt państwa”, stwarzała konieczność stałego podnoszenia płac, niszczyła pęd do oszczędzania oraz podstawy do kredytowania. Sprzyjała także spekulacji i pobudzała do strajkowania. Dlatego w projekcie programu polityki ekonomicznej i finansowej z 1920 r. uznał, że najważniejszym celem, do którego winna zmierzać polityka rządu jest ustalenie stabilnej wartości pieniądza ${ }^{39}$.

W. Grabski już wtedy przygotowywał się do przeprowadzenia reformy walutowej. Widział potrzebę zastąpienia słabnącej marki polskiej mocnym złotym polskim. Skuteczność reformy uzależniał od spełnienia kilku warunków. Po pierwsze, złotego można było wprowadzić wówczas, gdy wydatki zwyczajne państwa pokrywałyby dochody skarbowe, a na wydatki nadzwyczajne musiałyby wystarczyć pożyczki krajowe, bądź zagraniczne. Po drugie, emisję złotych należało powierzyć bankowi, a nie rządowi, „opartemu o czynniki poza Rządem stojące", czyli bankowi niezależnemu. Po trzecie, nową walutę należało zabezpieczyć odpowiednią ilością złota, srebra i dewiz zagranicznych. Złoty polski nie mógł być nadużywany dla celów pokrywania deficytu budżetowego, jak to działo się z marką polską ${ }^{40}$.

37 „Po powiatach namnożyła się liczba dygnitarzy państwowych, wyrokujących i dysponujących. Jest to gorszące w oczach ludu, a marnotrawstwem grosza publicznego. Daleko idące reformy są tu konieczne. Oczywiście, że źródłem złego jest brak wytycznych w rozwoju systemu administracyjnego w Polsce. Wytyczne winny być wspólne dla całego Państwa” (ibidem, s. 25).

38 „Gospodarcze wydatki na urządzenia biurowe powinny się sprowadzać do niezbędnych rzeczy, wyłączając wszelki zbytek. Brak środków w Skarbie nie pozwala na takie wydatki dzisiaj, jak budowa nowych wagonów salonowych, kupno automobili, powozów i koni wyjazdowych, których i tak jest aż za dużo" (ibidem).

${ }^{39}$ Ibidem, s. 14-15.

${ }^{40}$ Ibidem, s. 35 . 
W. Grabski podkreślał, że dobrze funkcjonujący system walutowy i kredytowy zależy nie tylko od poprawy sytuacji gospodarczej, lecz także od sanacji instytucji bankowych. Życiu gospodarczemu konieczne było dostarczanie środków kredytowych. Jest rzeczą powszechnie znaną, że w czasie kryzysu finansowego słabsze banki padają. Nie można jednak dopuścić, aby z powodu psychozy społecznej narażona została stabilność systemu bankowego. Rząd nie może odmówić w trudnej sytuacji pomocy instytucjom kredytowym, ale jednocześnie musi domagać się od banków przeprowadzenia reform wewnętrznych ${ }^{41}$. Rząd powinien występować o sankcje zarówno wobec banków, jak i osób, którym powierza się fundusze publiczne i które lokują je lekkomyślnie.

W. Grabski, w swym programie, na pierwszy plan wysuwał uzdrowienie i potanienie kredytu. Tymczasem stopa procentowa była zbyt wysoka, a uzyskaniu kredytu towarzyszyły rozliczne trudności. Przedsiębiorcy zużywali zbyt dużo energii i ponosili „fałszywe koszty”, ubiegając się o pożyczkę ${ }^{42}$. W. Grabski uważał, że trzeba robić wszystko, aby osiągnąć długoterminowy kredyt hipoteczny. Wielki kredyt hipoteczny, który istniał przed I wojną światową, był niemożliwy w warunkach powojennych. Dlaczego kredyt ten funkcjonował przed wojną? Grabski odpowiadał: „Bo listy były kupowane, ale dziś, jeżeli Rząd ich nie kupi, to nikt ich nie kupi, jeżeli Rząd ma te listy nabywać, to po co wydawać pieniądze na papier i drukowanie listów? Jeżeli Rząd je ma kupować i trzymać w szufladzie, to trzeba powiedzieć, że Rząd ma dawać kredyt”43.

Co powinni czynić producenci, jeśli odmawia się im kredytu lub żąda się od niego 5, 6, 10\% miesięcznie? Rezygnować z produkcji? - w żadnym przypadku! Producent musi sam wytwarzać we własnym warsztacie swój własny kapitał obrotowy ${ }^{44}$. Działalność taka była jednak niewystarczająca. Jeśli kraj miałby nadrobić opóźnienia gospodarcze, to rząd i sfery finansowe miały najwięcej do zrobienia. Grabski apelował do władz i do społeczeństwa o wykształcenie siły

${ }^{41}$ W. Grabski, Program walki z kryzysem gospodarczym w Polsce, Warszawa 1925, s. 40-41.

42 „Ubieganie się o kredyt, pochłaniają znaczną część zysku, któryby produkcja dawała, znaczną część energji, którą kierownicy w tę produkcję wkładają ku jej powodzeniu; stosunki te paraliżują tę energję, wytwarzają takie fałszywe koszty, wywołane tem, że się na coś rachuje, a coś nie dopisuje, jednem słowem stosunki te są w obecnym momencie największym szkopułem, największą trudnością dla urzeczywistnienia wielkiego programu ekonomicznego, jakim jest potanienie produkcji. I dlatego też akcja kredytu musi być szeroko zakrojona, ażeby dała pewne rezultaty... Ludziom się wydaje, że to jest coś nienormalnego, że ktoś jest temu winien, że gdyby nie coś, co stoi na przeszkodzie, to prawdopodobnie kredyt byłby. Gdyby tak było, że wystarczy mieć niezadłużony objekt i już byłby kredyt, to ludzkość miałaby bez porównania łatwiejszy przebieg dotychczasowego życia, fakt, że są domy jest niewystarczający, ponieważ nie przynoszą dochodu" (ibidem, s. 22).

${ }^{43}$ Ibidem, s. 24.

${ }^{44}$ Ibidem, s. 25. 
moralnej, która zamieni się w wartości ekonomiczne: ,zawsze istnieje ta możność zależna od siły woli i charakteru, tj. właściwych sił duchowych danego narodu i społeczeństwa. Dlatego jedne narody ten proces wytwarzają, a inne narody mają częstsze kryzysy i te kryzysy muszą je uczyć rozumu i zmuszają do tego" ${ }^{45}$.

\section{Polityka przemysłowa i inwestycyjna}

W. Grabski, będąc premierem, wypowiedział się jasno, że pierwsze miejsce w pracy społeczeństwa i rządu „musi zająć” produkcja. Potrzeby kraju powinna zaspokajać głównie własna wytwórczość. Nie oznaczało to jednak opowiedzenia się za polityką autarkiczną ${ }^{46}$.

W pierwszych latach powojennych przyczynił się zdecydowanie do odejścia od gospodarki wojennej, przezwyciężenia silnych tendencji etatystycznych i przejścia do gospodarki wolnorynkowej. Popierał indywidualną i zbiorową inicjatywę ekonomiczną oraz ograniczanie funkcji ekonomicznych państwa do ściśle koniecznych zadań. Opowiadał się za wolnością w wytwarzaniu i obrocie towarowym oraz za „Zwijaniem agend państwowych wszędzie tam, gdzie inicjatywa prywatna lepiej i sprężyściej zastąpić może maszynę państwową. Oddaniem żeglugi państwowej przedsiębiorstwom. Udziałem producentów w wykonywaniu monopoli państwowych... Ograniczeniem bezpośredniej akcji Państwa w udzielaniu pożyczek..."47.

Rola państwa w zakresie przemysłu i inwestycji powinna ograniczać się do „wytworzenia wielkiego przemysłu wojennego" oraz wspierania wytwórczości rolnej (głównie cukrownictwa), branży budowlanej, naftowej i drzewnej oraz innych opartych na bazie surowców krajowych i eksploatacji bogactw naturalnych. Państwo powinno również pomagać (kredyty, gwarancje) przy zakupie głównych środków produkcji dla rolnictwa i przemysłu ${ }^{48}$. Szczególną opieką należało też otoczyć drobną wytwórczość ${ }^{49}$.

${ }^{45}$ Ibidem.

46 „Najważniejszą rzeczą jest, ażebyśmy, jako organizm gospodarczy w granicach istniejących od 6 lat potrafili istotnie zadośćuczynić własną produkcją, tym wszystkim naszym potrzebom, które wypływają z naturalnych właściwości bogactw naszej gleby. Oczywiście, jeżeliby ktoś stanął na tym gruncie, że każdy kraj musi wszystko sam dla siebie produkować, byłoby to pod względem gospodarczym rzeczą zupełnie niemożliwą, bo np. kawy i herbaty produkować nie możemy" (s. 17).

${ }^{47}$ W. Grabski, Projekt programu..., s. 8-9.

${ }^{48}$ Ibidem, s. 11-12.

49 „Chroniąc produkcję w ogóle, należy szczególną pieczą otoczyć „drobnego” producenta czy w miastach czy na wsi. Rząd postulat ten całkowicie uznaje i gotów jest przyczyniać się do wszystkiego, co w zakresie tej pieczy oparte będzie na zdrowych podstawach. Za najzdrowsze Rząd 
Wielokrotnie powtarzał, że należy prowadzić racjonalną politykę inwestycyjną. Na pierwszy plan wysuwał budowę infrastruktury (zob. rozdz. II, pkt 3). Zaniedbania w tym zakresie były ogromne. Utrudniały one funkcjonowanie gospodarki i były bardzo uciążliwe dla społeczeństwa.

Najpilniejszym zadaniem było podjęcie inwestycji na obszarach wiejskich. Polski chłop musi dostrzec możliwości rozwojowe na własnym terenie. „Bez wiary ludu we własne państwo nie ma nic trwałego... państwowości naszej nie da się utrzymać. Polska nie dołączy do krajów Zachodu" ${ }^{50}$. Potrzeba zatem, aby przeludniona i ciemna wieś mogła mieć lepsze warunki do życia i pracy. Chodziło o rzeczy zwykłe, tj. drogi dojazdowe do stacji kolejowych, ogniotrwałe zabudowania, szkoły na przyzwoitym poziomie, melioracje, komasacje gruntów itp. ${ }^{51}$

Grabski był realistą i dobrze wiedział, że do przeprowadzenia szeroko zakrojonej akcji inwestycyjnej pojedynczy powiat jest za słaby. Dlatego też zaproponował utworzenie Celowego Związku Inwestycyjnego Samorządów Powiatowych ${ }^{52}$. Przemawiały za tym dwa zasadnicze argumenty: brak na szczeblu powiatowym (dość często) kadry kierowniczej na odpowiednim poziomie oraz trudności w uzyskaniu pożyczki zagranicznej (mała siła przebicia). Związek powiatów powinien obejmować powiaty sąsiadujące, niekoniecznie z jednego województwa. Jego zadaniem będzie opracowanie wspólnego programu i planu finansowego oraz nadzór nad wykonaniem inwestycji. W tym planie należy uwzględnić udział kapitału zagranicznego ${ }^{53}$.

Błędem byłoby - przekonywał Grabski - aby na obszarze całego kraju organizować celowe związki inwestycyjne. Powodzenie tego związku zależy od tego, aby $\mathrm{w}$ pierwszej kolejności zorganizowały się powiaty najbardziej predestynowane do własnych wysiłków, dysponujące odpowiednią kadrą oraz ludnością z „wyrobioną pracowitością”. Proponował połączyć szerokim pasmem Warszawę z Poznańskiem. Stolica Polski i jej otoczenie (wschodni krajobraz) dołączyłaby wówczas do kręgu kultury Zachodu. Za inwestycje płaciłaby ludność tak, jak w mieście za kanalizację czy elektryfikację ${ }^{54}$.

uznaje to wszystko, co wzmaga siłę wytwórczą tych szerokich warstw ludności. Wśród tych zadań szczególną wagę Rząd przywiązuje do zorganizowania przerobu wytworów, drobnego rolnictwa na eksport" (W. Grabski, Program walki..., s. 43).

${ }^{50}$ W. Grabski, Celowy Zwiąek Inwestycyjny Samorząów Powiatowych, Warszawa 1928, s. 18.

${ }^{51}$ Ibidem, s. 24.

${ }^{52}$ Ibidem, s. 19.

${ }^{53}$ Ibidem.

${ }^{54}$ Ibidem, s. 21-23. 


\section{Polityka agrarna}

Główne cele polityki rolnej określił Grabski w broszurze, przygotowanej w więzieniu niemieckim (w twierdzy Modlin) w 1918 r. pt.: Cele i zadania polityki agrarnej $w$ Polsce. Za najważniejszy cel uznał maksymalizację wydajności użytków rolnych oraz dążność do zapewnienia ludności rolniczej znacznie lepszych warunków bytu i rozwoju. Grabski przestrzegał, że zaniedbanie społecznego aspektu polityki rolnej może doprowadzić do anarchii i destrukcji, czego przykładem były ówczesne stosunki w bolszewickiej Rosji5 ${ }^{55}$.

We wcześniejszym opracowaniu (1917) pisał, że obowiązkiem odrodzonej Rzeczypospolitej jest podnieść dobrobyt materialny i kulturalny „ubogich, nieoświeconych włościan i robotników”. Powtarzał często, że klasy posiadające muszą ponieść ofiary materialne na rzecz silnej Polski. Po odzyskaniu niepodległości konieczna była koncentracja wysiłku wszystkich warstw społecznych ${ }^{56}$.

W odrodzonej Polsce chłopi liczyli, że w wolnym kraju ich położenie ulegnie zdecydowanej poprawie. Pod naciskiem partii ludowych, przy wsparciu Grabskiego, Sejm zatwierdził ustawy o reformie rolnej (1920 i 1925 r.). Nie zadowoliły one jednak większości rolników. Wieś oczekiwała dużej pomocy państwa (zwłaszcza finansowej) oraz protekcyjnej polityki rolnej. Powojenne trudności gospodarcze nie pozwoliły jednak na zaspokojenie nadmiernych roszczeń producentów rolnych. W tej sytuacji pojawiło się rozczarowanie i rozgorzała krytyka sfer rządowych.

Ziemianie przejawiali początkowo stosunek pozytywny do zachodzących przemian. Kiedy uwidoczniły się jednak trudności gospodarcze i kredytowe, a ustawodawstwo podatkowe nabrało wyraźnie charakteru antyziemiańskiego, nastroje wśród właścicieli majątków pogorszyły się ${ }^{57}$. Grabski pisał: „W gazetach i pismach rolniczych nie było numeru, nie było zebrania $\mathrm{z}$ odczytami publicznymi, gdzie by nie były wypowiedziane z całą apodyktycznością głosy, że dotychczas wszystkie rządy w Polsce lekceważyły i gnębiły rolników. Jakże można kochać państwo, którego rząd kogoś systematycznie gnębi.

W sprawozdaniu Centralnego Towarzystwa Rolniczego za 1925 r., we wstępie, na pierwszej stronicy odmalowana jest polityka rządu, jako wysoce dla rolnictwa nieprzychylna, a dalej $\mathrm{w}$ samej treści sprawozdania wydziału

\footnotetext{
${ }^{55}$ M. M. Drozdowski, Władysław Grabski, Rzeszów-Warszawa, s. 73.

${ }^{56} \mathrm{~W}$. Grabski, Podstawy sity wewnętrznej państwa polskiego. Materiaty i studia w sprawie odbudowania państwa polskiego, Piotrogród 1917.

${ }^{57}$ W. Grabski, Dwa lata pracy..., s. 321.
} 
ekonomicznego znajdujemy całą pełną litanię wyjednanych od rządu ulg, kredytów, pozwoleń, subwencji, zmian rozporządzeń. Okazuje się, że te fakty, których bogaty spis mówi za siebie i wskazują na przychylność rządu dla postulatów rolników, nie liczą się za nic przy odtwarzaniu nastroju ogólnego. Że rolnicy byli nieustannie krzywdzeni, jest to dziś dogmat wiary, którzy wyznają oni wszyscy, wielcy czy mali”,58.

Podzielał on częściowo racje rolników. W większości nie korzystali bowiem z kredytów, subwencji i innych form pomocy rządu. Władze państwowe nie miały bezpośredniego kontaktu z włościanami. Reprezentowały ich organizacje, które były bardzo często podporządkowane partiom politycznym. Zdarzało się niejednokrotnie, że urzędnik organizacji i reprezentant partii na dany okręg, to jedna i ta sama osoba ${ }^{59}$. W kontekście spostrzeżeń Grabskiego nasuwa się analogia do dzisiejszej rzeczywistości politycznej w naszym kraju.

Pisze on dalej, że nawet jeśli pomoc rządowa trafiałaby bezpośrednio do rolników, to i tak nie zapewniono dobrobytu tej warstwie społecznej. Włościanie stawiali wysokie wymagania rządowi, domagając się podnoszenia cen na produkty rolne oraz subwencji i różnych ulg. Tymczasem ich wysiłki na rzecz wzrostu produkcji rolnej pozostawiały wiele do życzenia. Postawa ogółu rolników wymagała stanowczej poprawy. Grabski widział potrzebę zwiększenia świadczeń rolniczych. Większa ofiarność wsi mogła przynieść pozytywne skutki całemu społeczeństwu i umocnić pozycję rolnictwa w kraju: „Gdy ogół nasz będzie widział, że rolnicy oddani są z całym zamiłowaniem istotnej pracy wytwórczej, dającej duże rezultaty, i gdy się przekona, że rolnicy przez wysiłki swojej pracy doszli do tego, by móc dźwigać zwiększone ciężary życia państwowego, to będzie to dużo bardziej ważkim argumentem na korzyść tego, że rolnikom należy się w państwie pierwsze miejsce niż to, że ich jest dwie trzecie ludności”' ${ }^{\prime 60}$.

W 1937 r., kiedy poprawiła się sytuacja płatnicza wsi (wzrost cen na artykuły rolne), przeciwstawił się zdecydowanie przyjęciu przez Sejm siedemnastoletniego moratorium na spłaty długów w rolnictwie - zdaniem Grabskiego kupowaniu przez nich ziemi. Odsprzedaż gruntu chłopom uważał za najlepszy sposób oddłużania majątków ziemskich. $Z$ jednej strony proces ten wzmacniałby ekonomicznie gospodarstwa chłopskie, a z drugiej - zdejmowałby z ziemian piętno „korzystania z krzywdy wierzycieli”. Moratorium to uważał za pozorny przywilej, ponieważ jego skutki tłumiły działanie naturalnych mechanizmów gospodarczych $^{61}$.

${ }^{58}$ Ibidem.

${ }^{59}$ Ibidem, s. 324.

${ }^{60}$ Ibidem, s. 328.

${ }^{61} \mathrm{~W}$. Grabski, Reforma oddlużenia rolniczego na skutek wzrostu cen rolniczych, „Przegląd Ekonomiczny" 1937, t. 17. 
W. Grabski opowiadał się za zmianą polityki podatkowej w rolnictwie. Podatki, które uiszczali rolnicy były wielokrotnie mniejsze od podatków wpłaconych przez inne warstwy społeczne. Na nierolniczą mniejszość społeczeństwa przypadało około $75 \%$ ogółu podatków bezpośrednich. Rolnicy, którzy stanowili $2 / 3$ ogółu społeczeństwa, płacili około sześć razy mniej podatków per capita niż reszta ludności. Posłowie chłopscy w Sejmie „wykrzykiwali”, że główny ciężar podatków pośrednich spada na wieś. Grabski odpowiadał, że to jest nieprawdą. Ludność miast w przeliczeniu na głowę mieszkańca piła więcej wódki i paliła więcej tytoniu. To, że rolnicy przysparzają skarbowi znacznie mniej dochodów niż miasta, było rzeczą zupełnie naturalną. Tak było i w innych krajach ${ }^{62}$.

Dochody z podatku gruntowego w latach 1934-1939 utrzymywały się na stałym, niskim poziomie $-58 \mathrm{mln}$ zł rocznie. Natomiast z podatku przemysłowego miały wyraźny trend rosnący - z $174 \mathrm{mln}$ zł w 1934-1935 r. do $301 \mathrm{mln}$ zł w $1938-1939$ r. $^{63}$

W. Grabski, mimo surowej oceny rolnictwa i rolników, stał na stanowisku, że rząd powinien dbać o potrzeby rolnika, docenić go jako człowieka, obywatela kraju i producenta. Rolników uważał za cenną część społeczeństwa. Nie omieszkał jednak przy tym dodać: „Ale element ten ma słabą siłę rozwojową, zbytnio poddają się rutynie i zbyt łatwo podlega wszelkim czynnikom depresji. Jest to właściwość rolników u wielu również innych narodów”64.

W. Grabski nie byłby sobą, gdyby pozostał na pozycji krytykującego. Zastanawiał się, co należy zrobić, aby produkcja rolna była opłacalna. Radził najpierw uświadomić producentów rolnych, że stosunek cen towarów przemysłowych do rolniczych będzie zawsze niekorzystny dla rolnictwa. To była tendencja ogólnoświatowa i żadne działania rządu nie mogły jej zmienić. Natomiast możliwa była poprawa tej relacji. Najlepszym sposobem zwiększenia opłacalności produkcji rolnej, było - według niego - uszlachetnienie produkcji. Należało zatem zasiewać więcej areału pszenicą, ponieważ jej cena miała trend rosnący, zwiększał się też popyt na nią w kraju. Korzystne było również zwiększenie produkcji zwierzęcej. Rósł na nią popyt zewnętrzny, a ponadto miała przewagę nad produkcją roślinną (mniejsza zależność od warunków klimatycznych $)^{65}$.

Polityka agrarna Profesora Grabskiego przypomina mi zachowanie dobrego ojca. Traktował on wieś i rolników, jak własne dzieci. Kochał ich i cenił, nie szczędził im uwag i wskazówek, a jak było trzeba, także ostrych słów krytyki.

\footnotetext{
${ }^{62}$ Ibidem, s. 326-327.

${ }^{63}$ Maty rocznik statystyczny 1939, s. 380.

${ }^{64}$ W. Grabski, Dwa lata pracy..., s. 327.

${ }^{65}$ W. Grabski, Program walki..., s. 19-20.
} 


\section{Zagraniczna polityka ekonomiczna}

Po I wojnie światowej coraz większą rolę w świecie odgrywały międzynarodowe stosunki gospodarcze. W. Grabski zdawał sobie z tego sprawę i uważał, że w interesie Polski leży aktywny udział w ich regulowaniu. Wielokrotnie powtarzał, że Polska powinna być silna, aby przeciwstawić się, w razie potrzeby, niebezpieczeństwu grożącemu jej ze strony wschodniej i zachodniej. Podstawą bezpieczeństwa kraju oraz jego pozycji w świecie był rozwój gospodarczy.

Polska ze względu na swą powierzchnię (390 tys. $\mathrm{km}^{2}$ ) i duży potencjał ludnościowy $(35,1 \mathrm{mln} \text { w } 1935 \text { r. })^{66}$ liczyła się w polityce Europy Środkowo-Południowo-Wschodniej. Grabski zwracał uwagę na korzyści, jakie nasz kraj mógł odnieść ze współpracy gospodarczej w tym regionie. W sytuacji, kiedy organy gospodarcze Ligi Narodów (Biuro Pracy, a od 1926 r. - Komisja Ekonomiczna) nie spełniały pokładanych $\mathrm{w}$ nich nadziei, główną rolę w kształtowaniu międzynarodowych stosunków ekonomicznych w Europie przejęły konferencje międzynarodowe.

Główne źródło rozwoju gospodarki polskiej Grabski upatrywał w zbiorowym wysiłku całego społeczeństwa. Był to słuszny pogląd. Jednak, aby zapewnić wzrost gospodarczy, potrzebne były pieniądze. Tymczasem społeczeństwo polskie było biedne. Brakowało środków finansowych na reformy, funkcjonowanie państwa i inwestycje. Reformę walutową przeprowadził premier Grabski w oparciu o możliwości wewnętrzne kraju. Jednakże należy pamiętać, że nie było wówczas innego wyjścia. Pomocy zagranicznej nie otrzymaliśmy. Ponadto, znając mentalność Polaków, nie można było liczyć na długotrwałą ofiarność.

W sytuacji braku kapitału rodzimego konieczny był dopływ do Polski kapitału zagranicznego. Zapotrzebowanie na środki finansowe było duże, zasadniczo we wszystkich działach gospodarki - przemyśle, budowie infrastruktury, transporcie, rolnictwie i leśnictwie, budownictwie.

Pozyskanie kapitałów zagranicznych na korzystnych warunkach nie było rzeczą łatwą. Najpierw jednak należało przełamać opór wewnętrzny - w kręgach politycznych i w samym społeczeństwie. Ludzie niechętni napływowi obcego kapitału argumentowali, że Polska straci pełną niezależność polityczną i gospodarczą.

Aby rozproszyć nieuzasadnione obawy, zalecał Grabski prowadzenie akcji uświadamiającej. Przekonywał, że jeśli do polskiej wytwórczości nie zaangażuje się kapitału zagranicznego, to „Rezultat tego wszystkiego będzie ten, że Polska nie będzie miała co prawda obcych kapitałów u siebie, lecz jej mieszkańcy będą

\footnotetext{
${ }^{66}$ Mały rocznik statystyczny 1939, s. 10-11.
} 
musieli pójść w służbę obcego kapitału poza granice Państwa" ${ }^{67}$. W tej sytuacji zacofany kraj nie wykorzysta swojego dogodnego położenia jako pośrednik w handlu między Wschodem a Zachodem.

Grabski twierdził, że „wprzęgnięcie” obcego kapitału w polski organizm gospodarczy leży w interesie całego społeczeństwa ${ }^{68}$. Kapitał ten mógł też wpłynąć korzystnie na poprawę konkurencji, która uniemożliwi nadmierny zysk niektórych producentów ${ }^{69}$.

W. Grabski podkreślał, że należy myśleć realistycznie, a nie idealistycznie. Ten, kto liczył na kombinacje polityczne i poczucie międzynarodowej solidarności w zakresie dopływu środków finansowych z zagranicy, był w głębokim błędzie. Kapitał zagraniczny mógł napłynąć do Polski, wiedziony tylko materialnymi korzyściami. Ponadto inwestorzy zagraniczni musieliby mieć zaufanie do Polski jako do kraju, który zapewni spokój wewnętrzny i zewnętrzny ${ }^{70}$.

W. Grabski zdawał sobie sprawę z zagrożenia, jakie niosła ze sobą ekspansja kapitału zagranicznego: „Trzeba baczyć, by kapitał obcy nie zyskiwał sobie przewagi tam, gdzie to jest sprzeczne z interesem państwowym, by zwracał się w kierunkach, które pośrednio mogą podeprzeć rozwój wytwórczości rodzimej, by pracował obok kapitału własnego, a nie wypierał go z życia gospodarczego kraju. Są to już jednak problemy, które nie dotyczą pytania, czy kapitał obcy jest u nas koniecznym, lecz kwestji, w jakiej formie jest pożytecznym" "71.

W. Grabski kredyty zagraniczne uważał za konieczne zło, ale uczynił wiele, aby je pozyskać. Zwracał uwagę, że w całym świecie, od zawsze do dzisiaj, pożyczki odgrywały ważną rolę w gospodarce. Polska odrodzona, przeżywająca ciągłe trudności (odbudowa, wojna polsko-bolszewicka, inflacja, kryzysy ekonomiczne) miała duże zapotrzebowanie na waluty zagraniczne.

${ }^{67}$ G. Grabski, Projekt programu..., s. 40.

68 „Mocne i skuteczne wciągnięcie obcego kapitału w nasz organizm gospodarczy, jest w interesie wszystkich warstw ludności. Ludność wiejska wtedy dojdzie do zamożności, gdy miasto będzie zamożnem, gdy rozwinie się wielki przemysł. Dzisiejszy dobrobyt wsi jest w znacznym stopniu pozornym. Wieś wydobywa z miasta papierowe pieniądze, ale potrzebnych surowców, maszyn, gotowych produktów, któreby podnosiły kulturę rolną, wieś nie jest w stanie uzyskać w dostatecznych rozmiarach. Robotnik znowu jest w tem zainteresowany, by pracować w kraju a nie szukać niepewnego chleba za morzem" (ibidem, s. 41).

69 „Ustalanie się cen możliwem jest przy wzmożeniu produkcji, a wtedy tylko da się usunąć nieproporcjonalne zyski niektórych producentów. Jeżeli kapitał zagraniczny odegra u nas rolę szczupaków, które wpuszcza się do stawu z karpiami, by te ostatnie uchronić od nadmiernego tycia, to w takim razie spełni bardzo pożyteczną funkcję. Oczywiście, że nie jednego karpia zjedzą szczupaki, ale to jest ofiara nieunikniona" (ibidem).

${ }^{70}$ Ibidem, s. 42; W. Grabski, Program walki..., s. 49.

${ }^{71}$ W. Grabski, Projekt programu ..., s. 41. 
Grabski zastrzegał się jednak, że „nigdy nie przyjęlibyśmy żadnej kombinacji finansowej, najbardziej korzystnej, która byłaby połączona z zrzeczeniem się jakichkolwiek praw państwowych" "72. Był zatem za ubieganiem się o kredyty zagraniczne, ale bez warunków politycznych, które ograniczałyby suwerenność kraju. Przeciwstawiał się uzyskiwaniu pożyczek za zgodę na dzierżawę monopoli skarbowych. Uznał m.in. za całkowicie niedopuszczalne wydzierżawienie kolei państwowych w zamian za uzyskanie kredytu zagranicznego ${ }^{73}$.

W przekonaniu Grabskiego, kredyty zagraniczne nie mogły być przeznaczane na ratowanie budżetu. Powinny one służyć pobudzaniu życia gospodarczego, a zwłaszcza wzmożeniu zdolności emisyjnej Banku Polskiego i zwiększeniu obiegu pieniężnego. Pożyczkami zagranicznymi nie można pokrywać nadzwyczajnych wydatków budżetu wojskowego - twierdził Grabski. Wydatki nadzwyczajne na przemysł zbrojeniowy są ważniejsze dla wzmocnienia obronności kraju i należy przeznaczać na nie dochody z pożyczek wewnętrznych ${ }^{74}$. Zadłużanie się za granicą nie mogło być zbyt duże, ponieważ należało brać pod uwagę koszty spłacania kredytów ${ }^{75}$.

W tej kwestii polityka kolejnych ekip rządowych była zgodna z zaleceniami Grabskiego. Zadłużenie kraju zmniejszało się stopniowo z $4570 \mathrm{mln}$ zł w $1931 \mathrm{r}$. (trudności finansowe spowodowane kryzysem) do $2515 \mathrm{mln}$ zł w $1938 \mathrm{r}^{76}$

Po odzyskaniu niepodległości rząd podjął działania mające na celu nawiązanie stosunków handlowych z poszczególnymi państwami. Wcześniej każdy zabór utrzymywał wymianę towarową, głównie zaborczą. W. Grabski, u progu nie podległości, w swym programie polityki ekonomicznej, zaproponował zawarcie umów handlowych „możliwie ze wszystkimi sąsiednimi państwami”77. Szczególne znaczenie miały dla niego stosunki gospodarcze z Francją i Stanami Zjednoczonymi.

${ }^{72}$ W. Grabski, Program walki..., s. 27.

73 „Rząd zwraca się o upoważnienie do zaciągnięcia pożyczek zagranicznych z prawem wydzierżawiania jednego $\mathrm{z}$ istniejących u nas monopoli państwowych. Nie potrzebuję dodawać, że wydzierżawianie takie powinno być czynnością czysto gospodarczą i nie może w niczem wkraczać w dziedzinę polityki państwowej. $Z$ tej racji uważam za absolutnie niedopuszczalne wydzierżawianie kolei dla uzyskania pożyczki. Przy wydzierżawianiu monopolu państwowego zarówno prawa pracowników krajowych, jak i przywileje koncesyjne muszą być, oczywiście, zagwarantowane" (ibidem, s. 48).

${ }^{74}$ W. Grabski, Dwa lata pracy..., s. 340.

${ }^{75}$ „Ale w dążeniu do posiadania tej waluty nie można iść za daleko, gdyż nie można zapominać, że waluta zagraniczna, wprowadzona w tej lub innej postaci do kraju, wymaga, by kraj oddał ją z powrotem, amortyzując sumę wyłożoną i oprocentowując ją. Chwilowa ulga staje się w następstwie ciężarem i zależnością na długie lata od zagranicy" (W. Grabski, Projekt programu..., s. 38).

${ }^{76}$ Z. Landau, Pożyczki zagraniczne państwa, [w:] Encyklopedia historii gospodarczej..., s. 130; idem, Pożyczki zagraniczne państwa polskiego, 1918-1939, „Finanse” 1969, nr 6.

${ }^{77}$ Ibidem, s. 10. 
W polityce handlowej dążył do utrzymania równowagi bilansu płatniczego, właściwej polityki celnej, forsowania eksportu i ograniczania luksusowego importu.

W. Grabski generalnie opowiadał się za liberalną polityką handlową, w praktyce, ze względu na trudną sytuację gospodarczą Polski - za czasową ochroną celną rodzimej wytwórczości. Protekcjonizm uważał za konieczność. Podwyższanie ceł na wszystko byłoby ogromnym błędem, zwłaszcza na towary w kraju nie produkowane ${ }^{78}$.

Eksport powinien być podstawą polityki handlowej. Grabski oceniał w 1926 r., że „Dotychczasowe usiłowania Rządu i społeczeństwa w tym kierunku nie dały dostatecznych jeszcze rezultatów. Być może, że to właśnie jest dziedzina, w której najwięcej może należałoby dotychczas zrobić i dlatego też do tej dziedziny polityki eksportowej jak największą przywiązuje wagę"79. Niezbędnym warunkiem zwiększenia eksportu było wspieranie tych działów gospodarki, które miały zdolność eksportową. Chodziło, mówiąc konkretnie, o udzielanie ulg podatkowych i gwarancji proeksportowych dla przedsiębiorstw. Należało też nadal podtrzymywać, już stosowane, ulgi w zakresie taryf kolejowych w wywozie towarów za granicę. Poprawie powinna również ulec organizacja eksportu pod względem handlowym i technicznym.

\section{Polityka społeczna}

Po I wojnie światowej, pod wpływem radykalnych ugrupowań politycznych, doszło w Polsce i wielu innych krajach do rozbudowania prawa pracy i ustawodawstwa ubezpieczeń społecznych. Po wielkim kryzysie dokonano zmian na ogół w kierunku zwiększenia uprawnień klasy robotniczej. Rząd polski zdecydował się na nie, aby rozładować niezadowolenie w środowisku ludzi pracy. Starał się przy tym unikać zmian „kosztownych”80. Skrócono czas pracy

78 „Bez tego protekcjonizmu produkcja przemysłowa wprost nie mogłaby odbyć procesu sanacyjnego, procesu stanienia kosztów. Można się obawiać, że nadmierny protekcjonizm tę produkcję podroży... Przecież dla produkcji nie jest wyjściem tylko drogo sprzedawać, a jest wyjściem dużo sprzedawać i właściwie produkcja nie potrafi się szanować, jeżeli tego drugiego zagadnienia nie wykona. Musi ona dużo sprzedawać, a z chwilą, gdy chce dużo sprzedawać, musi sprzedawać na rynku krajowym przedmioty poniżej tego poziomu, do którego idzie protekcja celna, gdyż inaczej będzie się znajdowała wciąż w stanie krytycznym” (W. Grabski, Program walki..., s. 18).

${ }^{79}$ Ibidem, s. 21.

${ }^{80}$ Z. Landau, J. Tomaszewski, Lata interwencjonizmu państwowego 1935-1939, Warszawa 1989, s. 214. 
w górnictwie, przyjęto przepisy regulujące urlopy, wynagrodzenia oraz system ubezpieczeniowy. Z drugiej strony rząd zgodził się spełnić niektóre żądania pracodawców ${ }^{81}$.

W. Grabski uznawał za rzecz naturalną przestrzeganie w państwie demokratycznym prawa pracy i ustawodawstwa ubezpieczeń społecznych. Pełniąc funkcję premiera, przyczynił się do rozbudowy świadczeń społecznych (zob. rozdz. I). Jednak jako zdecydowany zwolennik gospodarki rynkowej był przeciwny rozbudowie świadczeń społecznych. W jego przekonaniu, tylko zwiększenie produkcji przemysłowej, rolnej i handlu oraz wzrost zatrudnienia mógł przynieść odczuwalną poprawę bytu ludziom pracy. Mówił w Sejmie w 1925 r.: „Wytworzenie większej wydajności pracy na całym terenie życia gospodarczego i państwowego będzie największym czynnikiem sprowadzenia oczekiwanego przez wszystkich potanienia kosztów życia" ${ }^{\text {"2 }}$. Aby zwiększyć wydajność pracy należało stworzyć ludziom pracy odpowiednie warunki w przedsiębiorstwach oraz zapewnić im niezbędną konsumpcję. Rząd powinien regulować ceny na chleb i mąkę, a samorządy miejskie - na produkty „rzeźne”"83.

W. Grabski przewidywał pomoc doraźną, szczególnie ważną w latach powojennych, w czasie kryzysu lub w przypadku klęsk żywiołowych. Obowiązkiem rządu jest „dawać pomoc państwową bezrobotnym i to pomoc nie tylko ograniczoną do miesięcy statutem określonych, ale póki trwa kryzys" ${ }^{\prime 4}$. Akceptował prawo robotników do strajku, ale widział też potrzebę zapewniania bezpieczeństwa przed terrorem i groźbami pod adresem tych, którzy chcieli pracować ${ }^{85}$.

Trzeba przyznać, że rząd w latach 30. postępował zgodnie z poglądem W. Grabskiego w sprawie finansowania sfery świadczeń społecznych. Potwierdzają to wydatki z budżetu Ministerstwa Opieki Społecznej na ten cel. W 1927/1928 r. (okres dobrej koniunktury) wynosiły one 29,6 mln zł, w 1933/1934 r. (najtrudniejsze lata kryzysu) - $58 \mathrm{mln}$ zł, a w 1938/1939 r. (poprawa koniunktury) - 14,4 $\mathrm{mln} \mathrm{z}^{86}$.

81 Rząd zgodził się na obniżenie składek ubezpieczeń: chorobowego, emerytalnego i wypadkowego najpierw na okres 1936-1937, a następnie przedłużył na czas od 1.04.1938 r. do 31.03.1939 r. (A. Koźniewski, Czasowe obniżenie składek $w$ ubezpieczeniach społecznych, „Przegląd Ubezpieczeń Społecznych” 1937, nr 8, s. 725-726).

${ }^{82}$ W. Grabski, Program walki..., s. 45.

${ }^{83}$ Ibidem, s. 44.

${ }^{84}$ Ibidem.

${ }^{85}$ W. Grabski, Projekt programu..., s. 13.

${ }^{86}$ Maty rocznik statystyczny 1939, s. 287. 
Polityka społeczna rządu była właściwa. Utwierdzają nas w tym przekonaniu współcześni badacze. Michael S. Gazzaniga pisze, że nadmierna opieka społeczna odbiera ludziom zdolność do zmagania się z otoczeniem. Potwierdzają to bowiem liczne dhugofalowe badania ${ }^{87}$. William A. Niskanen przytacza fragment orędzia o stanie państwa, wygłoszonego na początku 1935 r. przez prezydenta Franklina D. Roosevelta, w którym prezydent stwierdza, że „trwałe uzależnienie od zewnętrznej pomocy powoduje duchową i moralną dezintegrację, które okazują się zabójcze dla tkanki życia społecznego". W. A. Niskanen dodaje dalej, że dzisiaj (1996 r.), ponad sześćdziesiąt lat po tym, jak wygłoszono te słowa, trzeba powiedzieć wyraźnie, że trwałe uzależnienie od pomocy jest o wiele groźniejsze niż przypuszczał prezydent Roosevelt ${ }^{88}$.

${ }^{87}$ M. S. Gazzaniga, Przyrodniczy umyst, [w:] Odkrywając wolność..., s. 766; W. A. Niskanen, Państwo opiekuńcze i kultura ubóstwa, [w:] ibidem, s. 771.

${ }^{88}$ W. A. Niskanen, Państwo opiekuńcze..., s. 771. 


\section{Rozdzial IV}

\section{Poglądy agrarne Władysława Grabskiego}

\section{Podstawowe zasady ustroju agrarnego Polski}

Władysław Grabski w swej fundamentalnej pracy Historia wsi w Polsce zasadniczą część opracowania poświęcił rozwojowi ustroju agrarnego Polski ${ }^{1}$. Starał się w niej uzasadnić konieczność ukształtowania właściwych stosunków agrarnych z punktu widzenia rozwoju gospodarczego, społecznego, politycznego i kulturowego kraju.

Na podstawie Historii wsi w Polsce, a zwłaszcza jej części zatytułowanej „Rozwój ustroju agrarnego Polski” oraz innych prac W. Grabskiego można wyodrębnić następujące zasady ustroju rolnego, które powinny być wprowadzone w Polsce:

- podstawą zdrowego ustroju agrarnego jest w każdej epoce historycznej indywidualizm gospodarczy (prywatna własność rolniczych czynników produkcji $)^{2}$,

- zróżnicowana struktura agrarna, ukształtowana w procesie historycznym, jest obiektywną cechą ustroju rolnego ${ }^{3}$,

- należy umacniać sektor chłopski w rolnictwie i dążyć do przekształcenia gospodarstw włościańskich w gospodarstwa farmerskie, zdolne do inwestowania i rozwoju,

${ }^{1}$ W. Grabski, Historia wsi w Polsce, Warszawa 2004.

2 ,Ja jestem przekonanym indywidualistą, to jest wierzę, iż społeczeństwo nasze może się dźwignąć z lenistwa i niechlujstwa, apatii tylko przez silny indywidualizm członków wielkiej zbiorowości, utajonych sił naszego narodu, jakim są włościanie”. List W. Grabskiego do Zofii Kiedroniowej (1906 r.), cyt. za: M. M. Drozdowski, Władysław Grabski, Rzeszów 2004, s. 32; zob. też: K. Korab, Władystaw Grabski jako socjolog wsi, Warszawa 2004, s. 227.

${ }^{3}$ W. Grabski, Historia wsi..., s. 64-68. 
- należy eliminować walkę klasową na wsi i zapewnić warunki do koegzystencji folwarków i gospodarstw chłopskich,

- ustrój agrarny w wyniku reform państwowych i działania mechanizmów rynkowych podlega ciągłej ewolucji ${ }^{4}$.

W. Grabski, formułując postulaty dotyczące ustroju agrarnego w Polsce, miał na uwadze głównie dwa cele: 1) ekonomiczny, tj. wzrost produkcji rolnej, 2) społeczny, podniesienie ludności wiejskiej na wyższym poziom materialny, kultury i życia publicznego ${ }^{5}$.

\section{Wieś jako podstawa rozwoju społeczno-gospodarczego}

Rolnictwo polskie charakteryzowało się, według Grabskiego, zacofaniem ekonomicznym i społecznym. Mogło zatem być potencjalnym zaczynem niepokojów społecznych, szczególnie niebezpiecznych, gdyż skorelowanych z niezadowoleniem z poziomu życia ludności miast. Stąd też poglądy agrarne Grabskiego koncentrowały się na czynnikach postępu ekonomicznego i społecznego. Formułował je, uwzględniając charakterystyczne cechy rolnictwa polskiego:

1) bardzo wysoką gęstość zaludnienia rolniczego;

2) przewagę mniejszej własności nad większą;

3) słabą wydajność zarówno mniejszej, jak i większej własności;

4) przewagę w sektorze chłopskim gospodarstw średniorolnych i niewielkie znaczenie gospodarstw karłowatych i większych;

5) istnienie znacznej liczby ludności bezrolnej, a wśród niej odrębnej warstwy - służby dworskiej ${ }^{6}$.

Przyszłość wsi można, zdaniem Grabskiego, rozpatrywać w kontekście walki klas, lub ewolucji sterowanej za pomocą odpowiednich metod polityki agrarnej. Walkę klas ogranicza Grabski tylko do szczególnych przypadków, gdy chodzi o zabezpieczenie interesów ekonomicznych pracowników najemnych. Jest to właściwie margines życia wsi, ciągle malejący ze względu na ograniczenie liczby folwarków oraz wzrost ich ekonomicznej efektywności. Zasadnicze dla

${ }^{4}$ Cechy ustroju agrarnego Polski w kontekście historycznym omawia szeroko W. J. Puliński w artykule Władystaw Grabski jako historyk i ekonomista, [w:] Historia gospodarcza i historia myśli ekonomicznej a teoria ekonomii. Problemy metodologiczne, red. J. Skodlarski, Łódź 2008, s. $177-190$.

${ }^{5}$ K. Korab, op.cit., s. 244.

${ }^{6}$ W. Grabski, Cele i zadania polityki agrarnej w Polsce, Warszawa 1918, s. 3. 
rozwoju społecznego znaczenie ma klasa chłopów pozbawiona wewnętrznych sprzeczności. Błędem byłoby sądzić, że ma to być wieś jednorodna, bo wszelka jednorodność jest dla Grabskiego hamulcem rozwoju. Wobec tego wieś stanowić będzie zbiór różnej wielkości gospodarstw (od małych do folwarcznych), pozostających we wzajemnej symbiozie ekonomicznej i społecznej ${ }^{7}$. Jest zatem - argumentował Grabski - podstawowym czynnikiem rozwoju solidarystycznego społeczeństwa. Nie mogły spełniać tej funkcji miasta, gdyż były one siedliskiem sprzeczności między robotnikami przemysłowymi a kapitałem. Ponadto środowisko miejskie wywiera destrukcyjny wpływ na zdolności kreatywne człowieka i pozbawia go możliwości tworzenia postępu ${ }^{8}$. Pojawia się tu pewna sprzeczność w jego poglądach, ponieważ w innym opracowaniu pisze: „Wieś daje wodzów, duchownych, administratorów, mniej natomiast wynalazców, nauczycieli, pisarzy, myślicieli, uczonych i polityków"9.

Miasta dla utrzymania swych funkcji gospodarczych, społecznych i politycznych wymagały ciągłego dopływu ludności wiejskiej. Jednak brak dostatecznego wykształcenia chłopów powodował, że zasilali oni z reguły szeregi proletariatu. Skazywało to ich tym samym na degradację społeczną, wynikającą z faktu przejścia z klasy drobnych posiadaczy do klasy robotników najemnych. Uzyskanie kwalifikacji stworzyłoby im szansę skutecznej konkurencji z obcym narodowo elementem, który opanował podstawową dla postępu, zdaniem Grabskiego, klasę społeczną w miastach, tj. drobnomieszczaństwo. Grabski liczył na rozwój inteligencji pochodzenia wiejskiego, a zwłaszcza na przenikanie do niej młodzieży chłopskiej ${ }^{10}$.

Groźbie walk klasowych próbował przeciwstawić siłę klasy średniej w miastach oraz wieś, której struktura powinna się opierać na średniej wielkości gospodarstwach chłopskich. Solidarne działanie klas średnich (na wsi i w mieście) miało zapewnić postęp społeczno-gospodarczy. Podstawę sukcesu widział w istniejącej strukturze gospodarczej kraju (rolniczo-przemysłowej) oraz pozytywnych cechach „duszy” chłopskiej ${ }^{11}$, a także zespole specyficznych właściwości wsi, które najogólniej wyrażają się w jej sile ekspansywnej, wynikającej $\mathrm{z}$,najwyższego stopnia symbiozy człowieka $\mathrm{z}$ przyrodą, jako czynnikiem

${ }^{7}$ W. Grabski, Wieś polska na tle rewolucji dziejowej, Warszawa 1929, s. 23.

${ }^{8}$ W. Grabski, Ekonomia rolnicza gospodarstw mniejszych, Warszawa 1910, s. 80.

${ }^{9}$ W. Grabski, Wieś polska na tle..., s. 12-13.

${ }^{10}$ Ibidem.

${ }^{11} \mathrm{~W}$ Materiałach $w$ sprawie włościańskiej pisał: „włościanin polski stanowi silny element zdrowia społecznego i nieprzebraną kopalnię dla odnowienia tych klas społecznych, które tego zdrowia nie posiadają i których indywidualizm doprowadził do zwyrodnienia" (W. Grabski, Materiały w sprawie włościańskiej, t. 1, Warszawa 1907, s. 22). 
produkcji... co sprawa, że inni ustępują z planu a wieś rośnie"12. Duże nadzieje wiązał ze wzrostem świadomości narodowej wsi polskiej, dzięki czemu możliwy był rozwój społeczeństwa polskiego w kierunku zespolenia „idei ludowej” z „ideą narodową” na gruncie „idei państwowej”" ${ }^{3}$. Grabski sądził, że wieś może spełnić funkcję ogólnospołecznego filaru postępu. Był przekonany, że wieś i rolnictwo, skieruje Polskę na nową drogę rozwoju kapitalizmu.

Nie była to jednak jego oryginalna koncepcja. Rodowód jej odnajdujemy w dziewiętnastowiecznym nurcie drobnomieszczańskiej myśli ekonomicznej. Odżyła w polskiej myśli agrarystycznej w okresie międzywojennym ${ }^{14}$. Kontynuację kierunku rozwoju gospodarczego Polski sugerowano $\mathrm{w}$ jednej $\mathrm{z}$ konkluzji w raporcie angielskiej misji Hiltona E. Younga (1924). Całości raportu nie aprobował premier Grabski ze względu na propozycje uzależnienia gospodarki polskiej od Anglii ${ }^{15}$. Przestrzegał także przed eskalacją wpływów innych państw. Uważał, że można przyspieszyć rozwój Polski, idąc proponowaną przez niego drogą. Aby osiągnąć ten cel, wieś musiała ulec daleko idącym przekształceniom. Nie mogła być, tak jak dotychczas, jedynie rezerwuarem siły roboczej dla fabryk i miast, a winna stać się sama środowiskiem ,wszelkich czynnych sił wytwórczych"16.

Charakterystyczną cechą poglądów Grabskiego jest uwypuklenie roli rodziny wiejskiej, a nie gospodarstwa rodzinnego jako podstawy stosunków społecznych na wsi. Tym samym problematykę ekonomicznych warunków funkcjonowania rodziny chłopskiej przesuwał na plan dalszy, a podkreślał znaczenie psychologicznych cech rodziny wiejskiej jako układu społecznego o wielkiej trwałości ${ }^{17}$. Rodzina chłopska stanowi układ wiecznie trwały, niezależny właściwie od ekonomicznych warunków jej funkcjonowania, czy to w czasach prehistorycznych, czy w feudalizmie, czy w kapitalizmie. Co więcej, wymusza ona rozwój ogólnych stosunków społecznych w kierunku najbardziej dla niej korzystnych (oczywiście w kierunku dekoncentracji) ${ }^{18}$.

${ }^{12}$ W. Grabski, Wieś jako siła społeczna, „Rolnictwo” 1936, T. II, z. 2, s. 8; idem, Znaczenie czynników psychicznych w produkcji rolnej, Warszawa 1927.

${ }^{13}$ W. Grabski, Idea Polski, Warszawa 1935, s. 143. Natomiast „lud miejski nie jest dojrzały do tego by rozumiał ideę Polski" (ibidem, s. 146).

${ }^{14}$ Zob. prace m.in. S. Żurawicki, Myśl ekonomiczno-polityczna w Polsce okresu międzywojennego, Warszawa 1970; S. Miłkowski, Agraryzm jako forma przebudowy ustroju społecznego, Kraków 1934; W. Piątkowski, Myśl agrarystyczna Stanisława Miłkowskiego, Warszawa 1983.

${ }^{15}$ Z. Landau, Polityczne aspekty działalności angielskiej misji doradców finansowych E. Hiltona Younga w Polsce (1923-1924), ,Zeszyty Naukowe Szkoły Głównej Planowania i Statystki” 1958, nr 9.

${ }^{16}$ W. Grabski, Wieś polska na tle..., s. 18.

${ }^{17}$ W. Grabski, System socjologii wsi, cz. II, „Roczniki Socjologii Wsi” 1937, T. II, s. 12-14.

${ }^{18}$ Ibidem, cz. I, s. 72-75. 
W. Grabski wyodrębnił rodzinę chłopską jako czynnik autonomiczny, niezależny od istniejących stosunków produkcji. „Prosty jest zatem wniosek, iż w doktrynie Grabskiego prawa rozwoju społecznego determinujące zmiany stosunków własności, poprzez dekoncentrację ziemi, wynikają z istnienia ponadczasowego, czyli właściwie ahistorycznie traktowanego zespołu dążeń rodziny chłopskiej do przetrwania i rozwoju - czyli z psychologicznych właściwości «duszy chłopskiej»-konkluduje Włodzimierz J. Puliński ${ }^{19}$.

Drobnotowarowe stosunki produkcji panujące w rolnictwie polskim ukształtowały zespół cech psychologicznych chłopów, adekwatny do istniejących warunków produkcji, tak w sensie technologicznym, jak i panujących stosunków produkcji. I ulegają one ewolucji w miarę zmiany tychże uwarunkowań. Przykład może stanowić tzw. problem przywiązania chłopa do ziemi, który przestał być aktualny w PRL. Nie są one, jak twierdził Grabski, czynnikiem determinującym rozwój, lecz są przez niego modelowane. Miał Grabski niewątpliwie rację wskazując na fakt, iż rodzina chłopska jest podstawową organizacją społeczeństwa wiejskiego, nie mylił się twierdząc, iż reprezentuje ona zespół cech odróżniających ją od innych rodzin ${ }^{20}$.

Należy tutaj zaznaczyć, że nie był on pierwszym w Polsce autorem podejmującym problematykę funkcjonowania rodziny chłopskiej. W socjologii polskiej problematykę tę podjęli W. Thomas i F. Znaniecki, których podstawowa praca poświęcona jest właśnie cechom specyficznym rodziny chłopskiej ${ }^{21}$. Pogląd o podstawowej roli rodziny chłopskiej w życiu gospodarczym i społecznym wsi był dla Grabskiego argumentem w dyskusji z lewicą chłopską oraz z kolektywistycznymi koncepcjami, które wskazywały społeczne walory i ekonomiczną efektywność uspołecznionego bądź też upaństwawianego rolnictwa. Chodziło o przeciwstawienie się propagandzie kolektywizacji, mającej swe źródło w akcji kołchozowizacji w ZSRR ${ }^{22}$. Już w 1904 r. na łamach „Gazety Rolniczej” wystąpił z ostrą krytyką „kwestii rolnej” Ludwika Krzywickiego, który proponował rozwój rolnictwa kolektywnego. Gospodarstwa kolektywne - zdaniem Krzywickiego umożliwiały upowszechnienie postępu technicznego w rolnictwie. Grabski przekonywał, że rozwój gospodarki chłopskiej, idący w kierunku indywidualizmu, jest na właściwej drodze ${ }^{23}$.

${ }^{19}$ W. J. Puliński, Poglady agrarne Władysława Grabskiego, praca doktorska, Łódź 1979, s. 236.

${ }^{20}$ Ibidem, s. 235.

${ }^{21}$ W. Thomas, F. Znaniecki, Chłop polski w Europie i Ameryce, Warszawa 1976.

${ }^{22}$ W. Grabski, System socjologii..., cz. II, s. 10-16.

${ }^{23}$ W. Sułkowska, Twórcy polskiej myśli ekonomicznej: Władysław Grabski, Kraków 1990, s. $26-27$. 
W. Grabski wierzył, że przemianami na wsi pokierują właściciele ziemscy. Wskazywał zmiany, jakie zaszły w ich świadomości. Twierdził bowiem, że „teraz większy właściciel żadnej przewagi i przemocy względem mniejszego nie jest w stanie czynić i nie chce tego robić, gdyż woli zgodę, która powoduje, iż życie na wsi jest milsze... woli sam ustąpić dla zysku mniejszym"24.

Ziemiaństwu wyznaczył następujące zadania: 1) pracę fachowo agronomiczną, 2) udział w życiu społecznym, 3) czuwanie nad wyrobieniem wśród obywateli ducha publicznego, 4) sprawowanie cywilizacyjnego przodownictwa ludności od ziemian ekonomicznie zależnej, 5) udział w pracach nad podniesieniem stanu całej okolicy ${ }^{25}$.

Tymczasem rzeczywistość społeczna była zgoła inna. W środowisku wiejskim panowało powszechne przekonanie, że między chłopstwem a resztą społeczeństwa (urzędnikami, ziemianami) istnieje przepaść, a państwo stało się narzędziem dyktatury obszarników i kapitalistów ${ }^{26}$.

W. Grabski dostrzegał sprzeczności na wsi i wyjaśniał, że wynikają one z tego, że „każdy lubi obmawiać drugiego... Tacy, którzy się panów i szlachty boją i im nie dowierzają, to ludzie, którzy się jeszcze nie zdążyli przyzwyczaić do dzisiejszych czasów, są ślepi i przesądni” ${ }^{27}$. Apelował do patriotycznych postaw ziemiaństwa, uważając, że będą one impulsem do samoczynnego rozwoju solidarystycznego społeczeństwa w oparciu o kreatywne siły wsi. Motyw ten pojawił się w pracy Grabskiego Rola społeczna obywatela wiejskiego ${ }^{28}$ już pod koniec XIX w. i przejawiał się w jego późniejszych opracowaniach. Właściwie do końca życia żywił on nadzieję, że ziemianie zdolni są uświadomić sobie wagę interesów ogólnospołecznych i swym działaniem wyjść im naprzeciw.

Warto zwrócić uwagę, że w tekstach poświęconych polityce ogólnogospodarczej Grabski wypowiadał się krytycznie o postawie zarówno ziemian, jak i chłopów. Natomiast ukazując w pozytywnym świetle właścicieli ziemskich i włościan, w prezentowanej koncepcji rozwoju społeczno-gospodarczego z wykorzystaniem wsi kierował się bardziej intencjami niż rzeczywistością.

Nie ulega jednak wątpliwości, że Grabski i ogół ludności wiejskiej (zwłaszcza młode pokolenie chłopów) dostrzegali potrzebę reform i przyspieszonego rozwoju gospodarki polskiej ${ }^{29}$.

${ }^{24}$ W. Grabski, Wieś polska na tle..., s. 81.

${ }^{25}$ W. Grabski, Rola społeczna obywatela wiejskiego, [w:] idem, W naszych sprawach, t. I, Warszawa 1899, s. 14-15.

${ }^{26}$ J. Chałasiński, Młode pokolenie chłopów, t. 1, Warszawa 1938, s. 21, s. 109-110, 113 i in.

${ }^{27}$ W. Grabski, Wieś polska na tle..., s. 81.

${ }^{28}$ W. Grabski, Rola spoleczna obywatela ..., s. 13-14.

29 J. Chałasiński, Młode pokolenie..., s. 105; J. Borkowski, Chtopi polscy w II Rzeczypospolitej, „Najnowsze Dzieje Polski 1914-1939” 1968, T. XIII. 


\section{Teoria dekoncentracji w rolnictwie}

Podstawowym warunkiem postępu w rolnictwie była ewolucja struktury agrarnej w kierunku umocnienia przewagi gospodarstw chłopskich. Konieczność tego procesu uzasadniała teoria dekoncentracji w rolnictwie. Znalazła ona uznanie wśród ekonomistów przełomu XIX i XX wieku. Na gruncie polskiej myśli ekonomiczno-społecznej uzasadnienie prawdziwości tej teorii zawierają prace W. Grabskiego. Za umacnianiem sektora chłopskiego przemawiały następujące czynniki: ewolucja stosunków produkcji, kształtowanie się efektywności wykorzystania pracy i ziemi w poszczególnych typach gospodarstw rolnych, postęp techniczny, przebieg koniunktury gospodarczej $\mathrm{w}$ drugiej połowie XIX w. i w pierwszych latach XX w.

\subsection{Wpływ zmian stosunków produkcji na strukturę agrarną}

Zagadnienie rozwoju struktury agrarnej ujmuje Grabski, jako proces historyczny, dokonujący się na tle społeczno-ekonomicznych stosunków funkcjonowania rolnictwa, w których uwypukla znaczenie stosunków własności panujących na danym etapie rozwoju społecznego ${ }^{30}$.

Analizując organizację produkcji rolnej w formacjach przedkapitalistycznych, Grabski twierdził, że produkcja $\mathrm{w}$ formacji feudalnej mogła być prowadzona w ramach wielkiego folwarku lub w małych gospodarstwach chłopów pańszczyźnianych. O ile wielka własność była zjawiskiem powszechnym, o tyle większe gospodarstwa były zjawiskiem zupełnie wyjątkowym. Pojawiły się one w wyniku odmiennych procesów gospodarczych w poszczególnych państwach ${ }^{31}$.

W Królestwie Polskim uwłaszczenie chłopów w 1864 r. otworzyło nowy rozdział w gospodarce chłopskiej. Przed uwłaszczeniem drobny rolnik nieustannie ustępował większemu. Od tej przełomowej daty rozpoczął się proces odwrotny, tj. rozpad własności folwarcznej i wzrost udziału własności chłopskiej. W latach 1864-1910 jej udział w ogólnej powierzchni gruntów w Królestwie Polskim wzrósł o $20 \%$ i wynosił $57 \%$ całego areału upraw ${ }^{32}$. Dane te jednak wydają się zawyżone. W zaborze pruskim obszar ziemi folwarcznej wydatnie się

\footnotetext{
${ }^{30}$ W. Grabski, Wieś i folwark, Warszawa 1930, s. 6.

${ }^{31}$ Ibidem, s. 6-8.

${ }^{32}$ W. Grabski, Ekonomia rolnicza..., s. 6-10.
} 
zwiększy ${ }^{33}$. W okresie międzywojennym areał majątków prywatnych znacznie się zmniejszył, w 1931 r. stanowiły one $25,8 \%$ ogólnej powierzchni ziemi ${ }^{34}$.

Wielkie gospodarstwa były - zdaniem Grabskiego - wytworem specyficznych relacji społeczno-ekonomicznych i politycznych. Rozwój kapitalizmu potwierdzał tezę o dekoncentracji produkcji rolnej. Kapitalizm przyczynił się wprawdzie do rozwoju większych gospodarstw dostarczając kredytu na inwestycje i zachęcając do stosowania postępu technicznego, ale z czasem - gdy okazało się, że gospodarstwa większe osiągają zbyt niski procent od kapitału w porównaniu z przedsiębiorstwami przemysłowymi zainteresowanie się kapitału większymi gospodarstwami znacznie zmalało. Okazało się, że gospodarstwa drobne dają większe czynsze dzierżawne, wyższe procenty itp., stanowią zatem lepszą lokatę kapitału $^{35}$. Dlaczego mniejsze gospodarstwa mają przewagę nad większymi? Przyczyny tego tkwią, według Grabskiego, w splocie korzystnych dla rozwoju mniejszej własności uwarunkowań przyrodniczych, ekonomicznych i społeczno-politycznych. Warunki te wynikają w pierwszym rzędzie z technologicznej specyfiki produkcji rolniczej odróżniającej ją od produkcji przemysłowej oraz psychologicznych cech drobnego rolnika, ukształtowanych w kontekście prywatnej własności środków produkcji rolniczej i bezpośredniego uczestnictwa $\mathrm{w}$ procesie produkcji. Specyfika ta wymaga ciągłego harmonizowania pracy człowieka i przyrody, a postulat ten lepiej spełniają chłopi, co dawało w tym zakresie przewagę gospodarstwom małym ${ }^{36}$. Symbioza człowieka z przyrodą sprzyja rozwojowi i pogłębianiu się indywidualizmu gospodarczego. Indywidualizm ów nie stwarza bariery dla rozwoju stosunków kapitalistycznych na wsi. Dzięki niemu następuje dostosowanie życia wsi do ogólnych wymogów funkcjonowania gospodarki kapitalistycznej. W konsekwencji indywidualizm determinuje formę przejawiania się kapitalizmu w rolnictwie, prowadząc nie do eliminacji gospodarstw chłopskich, ale do ich przekształcenia - w długim okresie - w gospodarstwa farmerskie. W istocie zatem kapitalizm jest raczej sojusznikiem rolnictwa chłopskiego, a nie jego wrogiem ${ }^{37}$.

${ }^{33}$ Według innych źródeł chłopi w Królestwie Polskim powiększyli swój areał o 8-9\% (J. Skodlarski, op.cit., s. 121; Encyklopedia historii gospodarczej Polski do 1945 r., Warszawa 1980, s. 176). W zaborze pruskim wzrost ziemi folwarcznej wzrósł z 47\% do $61 \%$ ogółu powierzchni użytków rolnych.

${ }^{34}$ Encyklopedia historii..., s. 176.

${ }^{35}$ W. Grabski, Reforma agrarna wstecz, Warszawa 1929. Odbitka z „Rolnika Ekonomisty”.

${ }^{36}$ W. Grabski, Ekonomia w produkcji rolnej, [w:] idem, W naszych sprawach, t. I, Warszawa 1900, s. 58; idem, Historia wsi w Polsce, Warszawa 1929, s. 431.

${ }^{37}$ W. Grabski, Historia wsi... s. 439-440; idem, Wieś polska i kapitalizm w rolnictwie, „Ekonomista” 1930, T. IV, s. 12. 


\subsection{Optymalny model struktury agrarnej}

Podstawę analizy struktury rolnej stanowiło w pracach Grabskiego założenie komplementarności gospodarstw różnej wielkości ${ }^{38}$. Idealna byłaby taka struktura, która grupowałaby racjonalnie prowadzone gospodarstwa różnej wielkości, pozostające w symbiozie społecznej i ekonomicznej. Oparciem jej byłby typ „wiodący”, który uzyska przewagę na drodze ewolucyjnej, zmierzającej do rozwoju rolnictwa w kierunku dekoncentracji, wspartej „dyskretną” polityką reform agrarnych ${ }^{39}$.

W. Grabski, zanim uzasadnił teorię dekoncentracji na gruncie polskim, przeprowadził głęboką analizę poszczególnych typów gospodarstw. Wyodrębnił następujące kategorie gospodarstw: karłowate (o powierzchni do 3-4 ha), średniorolne (od 4 do 15 ha), pełnorolne (od 15 do 30 ha), wielkochłopskie (powyżej $30 \mathrm{ha}$ ) i folwarki (od kilkudziesięciu do kilkuset ha).

W. Grabski oceniał negatywnie gospodarstwa karłowate o powierzchni nie gwarantującej egzystencji na poziomie minimalnym. W gospodarstwach tych widział siedlisko nędzy i zacofania. Twierdził, że właściciele terenów do 9 mórg (około 4,5 ha) z reguły muszą dorabiać pracą najemną. Gospodarstwa karłowate stanowiły przeszło połowę ogółu gospodarstw, w związku z czym wyraźnie rysowała się - zdaniem Grabskiego - nabrzmiała kwestia agrarna, która zagrażała strukturze społeczno-ekonomicznej kraju ${ }^{40}$.

Z punktu widzenia czysto ekonomicznego miały one także ujemne znaczenie, gdyż przy małym obszarze posiadanego gruntu utrzymanie pewnego poziomu życia na granicy minimum egzystencji jest możliwe tylko przy zupełnym ograniczeniu kontaktów rynkowych. Oznaczało to brak popytu konsumpcyjnego i w zasadzie produkcyjnego na wyroby przemysłowe. Rozwój rynku wewnętrznego był koniecznym warunkiem „startu” do gospodarki rozwiniętej. Pogląd ten wyrażali ekonomiści już w XIX w. ${ }^{41}$

Grabski pisał, że gospodarstwa karłowate konsumują właściwie cały wytworzony produkt. Nie spełniają zatem podstawowego zadania, jakim jest generowanie nadwyżki. Nie mogą więc przyczynić się do powiększania

${ }^{38}$ W. Grabski, Wieś i folwark..., s. 15 i 80-85. Odbicie tych poglądów odnajdujemy w pracach ekonomistów niemieckich, m.in. F. Lista, V. Schutza, V. Rlumahra, W. Roschera i Speringa (K. Kautsky, Kwestia agrarna, Warszawa 1958, s. 145-146).

39 W. J. Puliński, Struktura agrarna a rozwój gospodarczy $w$ pracach Władysława Grabskiego, „Acta Universitatis Lodziensis” 1982, Folia oeconomica 19, s. 185.

${ }^{40}$ W. Grabski, Materiaty w sprawie..., s. 14 i 27.

${ }^{41}$ J. Górski, Polska myśl ekonomiczna a rozwój gospodarczy, Warszawa 1963, s. 10 i nast. 
ogólnospołecznego funduszu akumulacji, a to podważa ich społeczną użyteczność ${ }^{42}$. Taką ocenę spotykamy w wydanych w 1907 r. Materiałach w sprawie wtościańskiej. Na jej radykalny charakter niewątpliwy wpływ wywarła rewolucja $1905 \mathrm{r}$. Koniec lat 20. był okresem pomyślnym dla całej gospodarki, w tym także dla rolnictwa polskiego ${ }^{43}$.

Wydawać się więc mogło, że wieś wchodzi w dłuższy okres prosperity, umożliwiający stopniową ewolucję struktury agrarnej. W pracy Wieś i folwark, wydanej w 1930 r., wskazuje dodatnie strony gospodarstw karłowatych. Twierdzi, że osiągają one najwyższą efektywność wykorzystania ziemi. Wielki kryzys skłonił ponownie Grabskiego do wysunięcia postulatu o konieczności likwidacji gospodarstw karłowatych ${ }^{44}$.

Posługując się danymi zaczerpniętymi z prac różnych autorów, Grabski uwypuklał fakt wysokiej produkcji globalnej z jednostki powierzchni, najwyższej w grupie gospodarstw chłopskich. Wysoką wydajność ziemi wiązał oczywiście z dużymi nakładami pracy w przeliczeniu na hektar. Jednak mała ilość posiadanej ziemi nie może być równoważona zwiększoną intensywnością upraw. Oznacza to, że mimo dużej intensywności wykorzystania ziemi i dużej wydajności z hektara, wydajność pracy musi pozostawać na niskim poziomie, który nie wynagradza dodatkowych nakładów pracy żywej przyrostem produkcji, możliwym do osiągnięcia na większej powierzchni (dodatkowe nakłady pracy są bardziej efektywne na większym obszarze) ${ }^{45}$.

W. Grabski zwrócił uwagę na jeszcze jedną cechę pozytywną gospodarstw karłowatych. W sytuacji braku migracji ze wsi do miast gospodarstwa te muszą spełniać funkcję rezerwuaru siły roboczej. Stan ,przechowywanej” siły roboczej zależy od polityki socjalnej i oświatowej państwa.

W konkluzji tego zagadnienia można sformułować opinię, że Grabski nie widział w swej ,idealnej strukturze agrarnej” miejsca dla gospodarstw karłowatych. Z drugiej strony, nie znajdował też możliwości ich likwidacji (w warunkach rolnictwa polskiego) działaniami „wewnątrz” rolnictwa. Szansę rozwiązania tego problemu dostrzegał $\mathrm{w}$ rozwoju pozarolniczych działów gospodarki ${ }^{46}$.

Koncepcja optymalnej struktury agrarnej Grabskiego ewoluowała pod wpływem zmian w sytuacji gospodarczo-społecznej kraju. W 1928/1929 r.,

${ }^{42}$ W. J. Puliński, Struktura agrarna ..., s. 189.

${ }^{43}$ Polskie osiagnięcia gospodarcze, red. J. Kaliński, Warszawa 2010, s. 156-161.

${ }^{44}$ W. Grabski, Reforma rolna a moralno-religijny stan wsi, Warszawa 1937; idem, Parcelacja agrarna wobec struktury, koniunktury i chwili dziejowej Polski, „Ekonomista” 1936, T. IV.

${ }^{45}$ W. J. Puliński, Struktura agrarna ..., s. 187.

${ }^{46}$ Ibidem, s. 188. 
w okresie widocznej poprawy koniunktury pisał, że w przeludnionej Polsce najkorzystniejszy wymiar gospodarstwa powinien wynosić od 5 do 15 ha. Areal taki pozwalał wykorzystać $\mathrm{w}$ pełni pracę rodziny na własnym zagonie, zapewniając jednocześnie najwyższą wydajność z hektara ${ }^{47}$. Nie mógł jednak, zdaniem Grabskiego, pełnić roli wiodącej. Wniosek ten oparł na badaniach rentowności gospodarstw chłopskich, przeprowadzonych przez J. Curzytka ${ }^{48}$. Wynikało z nich, że gospodarstwa tej wielkości miały wysoką produkcję, ale nie zapewniały wytworzenia dostatecznej nadwyżki, co stanowiło podstawowe kryterium oceny struktury agrarnej. Natomiast wysoką dochodowość gospodarstw o zbliżonych rozmiarach (0-15 ha) potwierdzają dane $\mathrm{z}$ „Małego Rocznika Statystycznego". Zgodnie z tym wskaźnikiem jeszcze lepsze wyniki miały gospodarstwa karłowate ${ }^{49}$. Ten rezultat osiągały dzięki dużej wydajności pracy „żywej”. Wskaźnik ten był dla Grabskiego podstawą oceny ekonomicznej efektywności gospodarstw i pozwolił mu sformułować prawo „ekonomiczno-społeczne” stwierdzające, że „praca na roli ma tym większą produkcyjność, wtedy kiedy jest na skalę mniejszą stosowana"50.

Warunki idealnej struktury agrarnej spełniały, według niego, pełnorolne gospodarstwa chłopskie (15-30 ha). Grabski, uzasadniając swój pogląd (w 1931 r.), powołuje się na wysokotowarowe rolnictwo farmerskie w Danii i Holandii ${ }^{51}$. Gospodarstwa o wielkości 15-30 ha miały zalety gospodarstw powyżej 30 ha, ale były pozbawione ich wad, gdyż przede wszystkim nie musiały korzystać ze stałego najmu siły roboczej. Analiza danych statystycznych potwierdza słuszność oceny W. Grabskiego ${ }^{52}$.

Negatywnie natomiast odnosił się Grabski do największych gospodarstw włościańskich o powierzchni powyżej 30 ha. Ustępowały one znacznie małorolnym, zarówno pod względem produkcji roślinnej, jak i zwierzęcej. Dochody netto $\mathrm{w}$ tej grupie gospodarstw były przeszło dwukrotnie niższe niż w karłowatych i średniorolnych ${ }^{53}$. Zadowalające wyniki, jakie osiągały te gospodarstwa,

${ }^{47}$ W. Grabski, Wieś i folwark..., s. 87.

${ }^{48}$ Ibidem, s. 39.

${ }^{49}$ Przeciętne dochody netto $\mathrm{z}$ ha (1933/34-1936/37) w gospodarstwach o powierzchni 10-15 ha wynosiły 46 zł. Natomiast gospodarstwa karłowate (3-5 ha) osiągały 51 zł dochodu (Mały Rocznik Statystyczny 1939, s. 74).

${ }^{50}$ W. Grabski, Ekonomia w produkcji rolnej ..., s. 71.

${ }^{51}$ Tezę tę uzasadnił Grabski w artykule Wieś polska i kapitalizm w rolnictwie.

52 Wprawdzie przeciętne dochody netto z ha (1933/34-1936/37) gospodarstwa o powierzchni 10-15 ha miały nieco niższe (46 zł) niż gospodarstwa (5-10 ha) - 48 zł, ale dużo mniejsze koszty produkcji - odpowiednio 175 zł i 211 zł, Mały Rocznik Statystyczny 1939, s. 74.

53 Gospodarstwa chłopskie (30-50 ha) osiągały przeciętne dochody netto $\mathrm{z}$ ha $21 \mathrm{zl}$, a karłowate $51 \mathrm{zl}$, średniorolne $-48 \mathrm{zł}$ (ibidem). 
stosując ekstensywne formy uprawy, prowadziły jednak, jak pisał Grabski, do „silnego zaniedbania produkcji roślinnej i zwierzęcej”54. Zły stan gospodarstw wielkochłopskich thumaczył zacofaniem kultury rolnej, które najbardziej uwidaczniało się właśnie $\mathrm{w}$ tej grupie gospodarstw. Nie omieszkał jednak wskazać cech dodatnich dużych gospodarstw chłopskich (powyżej $30 \mathrm{ha}$ ), a mianowicie tego, że dawały one zatrudnienie małorolnym i bezrolnym, wychowywały liczne rodziny, zasilały warstwy średnie, przodowały w życiu kulturalnym wsi ${ }^{55}$.

Dalsze pogłębienie nędzy wsi, zaostrzenie sprzeczności klasowych znalazło odbicie w modyfikacji jego poglądów. W 1936 r. pisał, że najbardziej odpowiedni typ reprezentują gospodarstwa $4-10 \mathrm{ha}^{56}$.

W. Grabski przeprowadził interesującą analizę sektora folwarcznego. Znał dobrze gospodarkę folwarczną, gdyż sam, przez pewien czas, zarządzał majątkiem w Borowie. Nie traktował tej kategorii gospodarstw jako monolitu. Dostrzegał ich wady i zalety.

Folwarki cechowała ta sama tendencja, która występowała w odniesieniu do gospodarstw chłopskich: wraz ze wzrostem obszaru gospodarstwa folwarcznego spadała produkcja globalna z hektara. Największą wydajność ziemi uzyskiwały folwarki o powierzchni około 25 ha. Przynosiły one duże dochody netto, miały zatem istotne znaczenie dla tworzenia potencjalnego funduszu rozwoju. Stosując duże nakłady pracy, spełniały także pozytywną funkcję społeczno-ekonomiczną, dając zatrudnienie okolicznym mieszkańcom. Niemniej ważną funkcją folwarków było stymulowanie przez właścicieli ziemskich procesów rozwoju społecznego, kultury oraz postępu technicznego ${ }^{57}$. Dla własności chłopskiej było również korzystne to, że folwarki reprezentowały wysoki poziom, gdyż wówczas mogły przyczyniać się do podwyższania kwalifikacji okolicznej ludności ${ }^{58}$.

Metody upraw w majątkach ziemskich nie odbiegały od stosowanych w gospodarce chłopskiej. W związku z tym, w modelowej strukturze agrarnej, zdaniem Grabskiego, powinna znaleźć się ta część własności folwarcznej, która sprosta walce konkurencyjnej z gospodarką chłopską.

Przypomnijmy, że Grabski do oceny ekonomicznej efektywności gospodarstw stosował wskaźnik wydajności pracy żywej. Jeśli zatem w tej grupie gospodarstw będzie realizowana najwyższa wydajność pracy, będą one dla niego najbardziej

${ }^{54}$ W. Grabski, Wieś i folwark..., s. 43.

55 W. Grabski, Mniejsze czy większe gospodarstwa włościańskie przy reformie rolnej, Warszawa 1937, s. 3.

${ }^{56}$ Ibidem, s. 5.

${ }^{57}$ W. Grabski, Historia Towarzystwa Rolniczego, t. 1, Warszawa 1904, s. 453.

${ }^{58}$ W. Grabski, Cele i zadania ..., s. 34-35. 
odpowiednie jako podstawa idealnej struktury agrarnej. Skupiają bowiem wtedy w sobie motywację produkcji, niezależną m.in. od bieżących wahań koniunktury (chodzi ich właścicielom o maksymalne wykorzystanie ziemi dla zaspokojenia własnych potrzeb), ale też stanowią najlepszą podstawę rozwoju, gdyż maksymalizują społeczną wydajność pracy w rolnictwie. Zakładając, że istnieje jakiś ukształtowany poziom spożycia, którego globalne rozmiary w skali społecznej wynikają z relacji między stopą wzrostu ludności a stopą wzrostu środków konsumpcji, można stwierdzić, że relacje te wyznaczają pewien minimalny, akceptowany poziom konsumpcji w skali mikro. A zatem, bez niebezpieczeństwa popełnienia większego błędu można przyjąć założenie, że rozmiary konsumpcji (w określonej grupie gospodarstw, np. do $15 \mathrm{ha}$ ) w niewielkim stopniu zależą od wielkości danego gospodarstwa, czyli te gospodarstwa, które osiągają większą wydajność pracy, maksymalizują także nadwyżkę ${ }^{59}$.

Idealna, zdaniem Grabskiego, struktura agrarna obejmowałaby więc gospodarstwa spełniające warunek minimum - zaspokajające potrzeby konsumpcyjne rodziny chłopskiej, oraz gospodarstwa spełniające warunek maksimum maksymalizujące nadwyżkę. Postulat ten spełniały większe gospodarstwa chłopskie i część kapitalistycznych folwarków. Stanowić one miały podstawę idealnej struktury agrarnej. Koncepcja idealnej struktury agrarnej W. Grabskiego opierała się na ocenie wydajności czynników produkcji rolniczej. Ekonomiczna efektywność tych gospodarstw zapewniała dobre warunki startu i nagromadzenia nadwyżki ${ }^{60}$.

W. Grabski twierdził, że na podstawie dostępnych danych statystycznych nie można sformułować jednoznacznej oceny użyteczności własności chłopskiej i folwarcznej. Folwarki zapewniały wyższe dochody brutto ${ }^{61}$. Natomiast gospodarstwa włościańskie, ze swej istoty, były predestynowane do osiągania wysokich

${ }^{59}$ W. J. Puliński, Struktura agrarna ..., s. 190 i 194. Grabski przykładał dużą wagę do możliwości maksymalizacji nadwyżki na danym obszarze ziemi użytkowanej rolniczo. Pisał: „miernikiem podstawowym (odnośnie parcelacji - przyp. autora) jest suma dóbr materialnych wyprodukowanych na danym terenie. Jeśli suma ta jest większa, to choćby mniej osób żyło na danym gruncie, korzyść społeczna będzie większa, gdyż z przewyżki produkcji nad konsumpcją miejscową korzystać będą inni członkowie danego społeczeństwa, których w sumie razem z miejscowymi, okaże się w ten sposób zawsze o tyle więcej, o ile produkcja sama będzie wyższa" (W. Grabski, Wieś i folwark..., s. 36).

${ }^{60}$ W. J. Puliński, Teoria dekoncentracji jako ekonomiczna przestanka agraryzmu $w$ poglądach Władystawa Grabskiego, „Roczniki Dziejów Ruchu Ludowego” 1983/1984, s. 165.

${ }^{61}$ W 1929 r. przychody majątków większych były wyższe na 1 ha użytków rolnych niż gospodarstw mniejszych o 196\%, w 1931 r. - 187\%, a w 1934 r. - aż o $251 \%$ (W. Roszkowski, Gospodarcza rola większej prywatnej własności ziemskiej w Polsce, 1918-1939, Warszawa 1986, s. 337-338). 
dochodów netto. Grabski sytuował gospodarstwa chłopskie wyżej od folwarków, zwłaszcza w zakresie hodowli i uprawy warzyw ${ }^{62}$. Majątki miały przewagę w produkcji zbóż. W jednej z ostatnich prac zakwestionował nawet wyższość folwarków w zakresie uprawy zbóż ${ }^{63}$. Wartość ziemi i kapitału w przeliczeniu na 1 ha użytków rolnych była wyższa $w$ gospodarstwach chłopskich ${ }^{64}$. Z kolei folwarki dostarczały nieco ponad połowę zboża na rynek wewnętrzny i na eksport ${ }^{65}$. Udział w produkcji globalnej miały jednak zdecydowanie większy niż sektor folwarczny. W rękach chłopskich znajdowało się w 1938 r. prawie $60 \%$ ziemi, a w ziemiańskich - tylko nieco ponad $24 \%{ }^{66}$. Należy przy tym pamiętać, że około 75\% ogółu ludności stanowiła społeczność wiejska. Zatem znaczna część produkcji przeznaczona była na samozaopatrzenie. Wyliczenie jej wysokości jest wprost niemożliwe, podobnie jak oszacowanie kosztów robocizny w gospodarstwach rodzinnych ${ }^{67}$.

Generalnie Grabski opowiadał się za rozwojem sektora chłopskiego. Zwracał uwagę na jego wysoką sprawność ekonomiczną i wzrost poziomu gospodarowania. W konsekwencji zwiększało to znaczenie własności chłopskiej i chłopi mogli torować sobie drogę do opanowania korzystnych dla nich dziedzin wytwórczości ${ }^{68}$.

${ }^{62}$ W. Grabski, Parcelacja agrarna wobec struktury, koniunktury i chwili dziejowej Polski, „Ekonomista” 1936, T. IV, s. 29; idem, Wieś i folwark..., s. 15-17.

${ }^{63}$ W. Grabski, Parcelacja agrarna ..., s. 6-7.

64 Według obliczeń W. Roszkowskiego, wartość budynków oraz inwentarza żywego i martwego w 1928 r. wynosiła 797 zł/ha użytków rolnych, zaś wraz z melioracjami - około 820 zł/ha, czyli nieco ponad połowę kapitału przypadającego na jednostkę powierzchni w gospodarstwach chłopskich. W latach 30. proporcja ta nie uległa zmianie. Badania Wacława Ponikowskiego potwierdzają ten stan rzeczy (W. Roszkowski, op.cit., s. 335; W. Ponikowski, Gospodarstwa folwarczne, Warszawa 1935, s. 9).

${ }^{65} \mathrm{~W}$ przeliczeniu na 1 ha użytków rolnych majątki większe dawały na rynek około 3 q zbóż, zaś gospodarstwa drobne - 0,7 q (W. Roszkowski, op.cit., s. 336).

${ }^{66}$ M. Mieszczankowski, Struktura agrarna Polski międzywojennej, Warszawa 1960, s. 147-148.

${ }^{67}$ Szczególną trudność sprawiało obliczenie kosztów robocizny w gospodarstwach chłopskich. Zadawalano się szacunkami orientacyjnymi, ponieważ nie było pełnego rozeznania nakładów pracy w gospodarstwach rodzinnych. Wyliczenia te były jednak konieczne, gdyż rzutowały one w głównej mierze na wnioski o wyższości lub niższości opłacalności gospodarstw folwarcznych i chłopskich z punktu widzenia czystego dochodu. Na podstawie szacunków Stanisława Antoniewskiego można przyjąć, że nakład pracy w gospodarstwach włościańskich był o 50\% wyższy (W. Roszkowski, op.cit., s. 335-336. S. Antoniewski, Z ekonomiki gospodarstw dużychi matych, Warszawa 1938, s. 113; zob. też: J. Stecki, Reforma rolna a kapitalizacja, „Przegląd Ekonomiczny” 1937, t. XVIII, s. 45; L. W. Biegeleisen, Teorya małej i wielkiej własności ziemskiej, Kraków 1918, s. 27-28).

${ }^{68}$ W. Grabski, Wieś i folwark..., s. 50. 
Kwestia dotycząca efektywnej ekonomicznie struktury agrarnej wzbudzała w okresie międzywojennym ogromne emocje. Pojawiło się wiele sprzecznych poglądów, o czym pisał Antoni Żabko-Potopowicz, dokonując wszechstronnego przeglądu opinii różnych autorów polskich z okresu międzywojennego ${ }^{69}$. Wojciech Roszkowski w kapitalnej pracy zatytułowanej Gospodarcza rola większej prywatnej własności ziemskiej w Polsce 1918-1939, przytoczył 27 opinii $^{70}$. Stanowisko Grabskiego aprobowali (całkowicie, bądź też częściowo): Juliusz Poniatowski, Leon W. Biegeleisen, Wacław Ponikowski, Stanisław Antoniewski, Witold Staniewicz, Zdzisław Ludkiewicz, Roman Rybarski, Jan K. Sondel, Błażej Stolarski ${ }^{71}$.

W. Roszkowski, oceniając opinie i polemiki autorów z okresu międzywojennego, uznał, że „najbardziej przekonywująco brzmiały wówczas głosy domagające się utrzymania pewnego zróżnicowania wielkości gospodarstw oraz postulujące stopniową, choć nie całkowitą parcelację dla wyrównania rażących dysproporcji struktury własności i częściowego choćby rozwiązania przeludnienia wsi" ${ }^{\prime 2}$.

W. Grabski usiłował sformułować koncepcję optymalnej struktury agrarnej. Sytuacja polskiego rolnictwa była jednak bardzo skomplikowana. Grabski, który zawsze liczył się z realiami gospodarczo-społecznymi kraju, przygotował zatem alternatywną koncepcję struktury agrarnej - jedynie możliwą i konieczną w polskich warunkach. Uwzględniała ona istniejące w Polsce przeludnienie agrarne, które skłoniło Grabskiego do stwierdzenia, że podstawą struktury agrarnej powinny być samodzielne gospodarstwa chłopskie. Miały one koegzystować z częścią gospodarstw folwarcznych, odznaczających się wysoką efektywnością ekonomiczną.

${ }^{69}$ A. Żabko-Potopowicz, Zagadnienie najkorzystniejszego stosunku między gospodarstwami wiejskimi różnych rozmiarów w polskiej literaturze naukowej, „Ekonomista” 1937, T. III, s. 39.

${ }^{70}$ Według W. Roszkowskiego do autorów najpełniej ujmujących ten problem należeli Stefan Schmidt i Wacław Ponikowski. S. Schmidt zajmował stanowisko pośrednie. Wskazywał on, że metoda liczenia produkcji gospodarstw większych i mniejszych zaproponowana przez W. Grabskiego zaniżała plony majątków. Opowiadał się on za uwzględnieniem wszystkich czynników społecznych, gospodarczych i politycznych w optymalizacji struktury agrarnej. W. Ponikowski przeciwstawiał się uproszczonemu porównywaniu wyników gospodarstw wielkich i małych. Za miarę dostatecznie ścisła i porównywalną, umożliwiająca wykazanie wyższości ekonomicznej, uznał dwa czynniki: dochód brutto i dochód społeczny (W. Roszkowski, op.cit., s. 333-334; S. Schmidt, Problemy związane z naprawa ustroju rolnego, „Ekonomista” 1938, T. II, s. 61-62; W. Ponikowski, Badanie porównawcze gospodarstw wiejskich rozmaitych wielkości lub rozmaitych typów pracy, „Roczniki Nauk Rolniczych i Leśnych” 1934, T. XXIII, s. 317-321).

${ }^{71}$ W. Roszkowski, op.cit., s. 332-337.

${ }^{72}$ Ibidem, s. 340. 
Rezygnacja ze sformułowanej uprzednio „optymalnej” struktury agrarnej na rzecz, nazwijmy to, struktury koniecznej, była przejawem realizmu Grabskiego. Likwidację przeludnienia agrarnego przyjął jako zasadniczą przesłankę determinującą program polityki agrarnej. Oznaczało to rezygnację z postulatu maksymalizacji nadwyżki na rzecz maksymalizacji produkcji globalnej. Fundusz akumulacji należało podporządkować kryterium społecznemu - rozumianemu, jako stworzenie warunków do zaspokojenia bieżących potrzeb konsumpcyjnych szerokich warstw ludności wiejskiej. W warunkach nędzy wsi polskiej należy to uznać za postulat postępowy ${ }^{73}$.

Nie oznaczało to oczywiście rezygnacji z wejścia na drogę przyspieszonego rozwoju, ale też niewątpliwie odsuwało w przyszłość okres startu na drodze rozwiązywania bieżących problemów społeczno-ekonomicznych.

Grabski był przekonany, że rolnictwo polskie będzie w sposób naturalny ewoluować w kierunku wyznaczonym przez rolnictwo krajów zachodnich, któremu przeciwstawiał nieracjonalne rolnictwo wschodu ${ }^{74}$. Pogląd ten wyraził w 1904 r. i wzmocnił go po rewolucji październikowej w Rosji.

Będąc przedstawicielem ziemiaństwa, propagował konieczność przywrócenia tej warstwie wiodącej roli społecznej, którą utraciła w XIX w. na rzecz burżuazji ${ }^{75}$. Widział $\mathrm{w}$ ziemiaństwie realną siłę zdolną przeciwstawić się socjalistycznej ideologii. Warunkiem powodzenia było podjęcie „pracy organicznej u podstaw”76, opartej na bezinteresownym spełnianiu „obowiązku publicznego" ${ }^{777}$.

\subsection{Postęp techniczny a struktura agrarna}

Wpływ postępu technicznego na ewolucję struktury agrarnej analizował Grabski, podobnie jak problem skali produkcji i specjalizacji, z punktu widzenia wzrostu produkcji rolnej. Generalnie rzecz biorąc, nie miał wątpliwości co do konieczności rozwoju agrotechniki. Niejednokrotnie zwracał uwagę na potrzebę szerzenia oświaty rolniczej i podnoszenia kwalifikacji (zob. rozdz. II). Natomiast uważał, że efektywność stosowania technik rolniczych zależy od struktury agrarnej.

${ }^{73}$ W. J. Puliński, Poglądy agrarne..., s. 178.

${ }^{74} \mathrm{~W}$ Historii Towarzystwa Rolniczego przekonywał, że w rolnictwie po lewej stronie Wisły dominuje „duch” zachodu. Natomiast „włościanie polscy na wschodzie królestwa pogrążeni byli w apatycznym niedbalstwie, pomimo niezłych nawet warunków egzystencji..." (s. 452-454).

${ }^{75}$ W. Grabski, Rola spoleczna obywatela, s. 13-15.

76 Większa część t. 2 Historii Towarzystwa Rolniczego poświęcona jest ziemiaństwu, realizującemu zasady ,pracy organicznej u podstaw”.

${ }^{77}$ W. Grabski, Rola społeczna obywatela ..., s. 22-23. 
Grabski dzielił techniki rolnicze na podnoszące wydajność pracy i na przyczyniające się do wzrostu produkcji z jednostki powierzchni ziemi. Rolę maszyn sprowadzał do substytucji pracy żywej. Twierdził, że korzyści z mechanizacji nikną wraz ze spadkiem obszaru gospodarstwa i wzrostem jego wyposażenia $\mathrm{w}$ pracę żywą. $\mathrm{W}$ wielkich gospodarstwach maszyny są jedynie w stanie zrównoważyć straty, jakie sprowadza produkcja na wielką skalę. Jest to oczywiście teza niesłuszna. Jej autor nie zauważył bowiem, że mechanizacja przeciwdziałając brakom siły roboczej, pozwala równolegle stosować techniki maksymalizujące produkcję. Pozostaje jeszcze do rozstrzygnięcia kwestia, czy brak mechanizacji w gospodarstwach rodzinnych, gdy istnieją duże zasoby siły roboczej, zmniejsza ich zdolność do zwiększania produkcji. Grabski uważał, że narzędzia $\mathrm{w}$ produkcji rolniczej odgrywają tylko pośrednią rolę ${ }^{78} \mathrm{~W}$ związku z tym mała własność może - dzięki indywidualnemu stosunkowi do warsztatu lepiej i taniej produkować i nawet przy malejących cenach otrzymywać dochody netto. Powyższe wywody oraz obserwacje jednoznacznych - jego zdaniem procesów historycznych przywiodły go do sformułowania prawa ekonomiczno-rolniczego, które stwierdzało, że „praca na roli tym większą ma produkcyjność, wtedy gdy jest na skalę mniejszą stosowana"79. Grabski nie doceniał wprawdzie technik podnoszących wydajność pracy, ale było to zrozumiałe w ówczesnych warunkach przeludnienia agrarnego i słabej możliwości zastąpienia pracy żywej uprzedmiotowioną. W tym przypadku rzeczywiście staranność uprawy mogła rosnąć wraz ze spadkiem rozmiarów gospodarstwa ${ }^{80}$.

W przeciwieństwie do sceptycznego stosunku do mechanizacji, pozytywnie wyrażał się Grabski o efektywności postępu technicznego, prowadzącego „wprost” do wzrostu produkcji rolniczej (np. stosowanie lepszego płodozmianu, nawożenia, lepszych nasion itp. zabiegów agrotechnicznych). Właśnie ten rodzaj postępu technicznego szczególnie zalecał na wsi polskiej. Są to metody niezwiązane bezpośrednio z rozwojem technicznym maszyn, lecz stosować je można właściwie bez zmian $\mathrm{w}$ technicznym uzbrojeniu pracy gospodarstwa. Wymagają jedynie aktywnej polityki państwa - szczególnie na polu oświaty rolniczej - a także rozwoju infrastruktury rolniczej ${ }^{81}$.

Dzięki dużej efektywności pracy żywej, stosowanej w gospodarstwach chłopskich, ich zdolności do racjonalnej absorpcji postępu technicznego i do

${ }^{78}$ W. Grabski, Ekonomia w produkcji rolnej, s. 70.

${ }^{79}$ Ibidem, s. 71.

${ }^{80}$ W. J. Puliński, Teoria dekoncentracji..., s. 160.

${ }^{81}$ W. Grabski, Celowy zwiazek inwestycyjny samorzadów powiatowych, Warszawa 1928, s. $13-14$. 
ciągłego harmonizowania pracy człowieka i przyrody, są one bardziej odporne na zasadnicze prawo determinujące wytwarzanie w rolnictwie ,prawo zmniejszającej się wydajności nakładów w rolnictwie" 82 .

W. Grabski zastanawiał się, w jakim stopniu wielkość gospodarstwa rolnego jest określana przez postęp techniczny. Nie zgadzał się on z twierdzeniem, że normy powierzchni gospodarstwa wynikają $\mathrm{z}$ technicznego doskonalenia narzędzi pracy. Pogląd, zgodnie z którym wydajniejszej maszynie musi odpowiadać większe gospodarstwo traktował jako „pobudzoną imaginację w kierunku materializmu dziejowego" $"$.

Grabski dowodził, że jeśli postęp techniczny stosowany w majątkach wielkiej własności będzie bardziej efektywny niż nakłady pracy żywej w gospodarstwach chłopskich, to uwidoczni się przewaga wielkiej własności. W przeciwnym wypadku postępować będą procesy dekoncentracji, tym bardziej, że gospodarstwa włościańskie miały pewną zdolność absorpcji nowej techniki i to tej, która jest najbardziej pożyteczna dla wzrostu produkcji.

W rzeczywistości folwarki nie były nośnikami nowoczesnej techniki rolniczej. W warunkach przeludnienia agrarnego właściciel zadowalał się optymalnym rozwiązaniem agrotechnicznym o stosunkowo niskiej intensywności i kapitałochłonności. Grabski zwracał uwagę na powszechne zacofanie folwarków, pisząc, że nasze wcale nie górowały, pod względem intensywności upraw, nad folwarkami rosyjskimi ${ }^{84}$.

W. Grabski uważał, że postęp techniczny w rolnictwie nie powoduje przewagi wielkiej własności nad mniejszą. Twierdził, że gospodarstwa chłopskie pełnorolne, dzięki specyficznym cechom funkcjonowania rolnictwa, a szczególnie dzięki stosowaniu dużych nakładów wysoce efektywnej pracy żywej, utrzymują przewagę nad gospodarstwami wielkimi.

Stwierdzenie Grabskiego, że postęp techniczny nie prowadzi do eliminacji gospodarstw chłopskich, stanowiło podstawę do uznania trwałości gospodarki chłopskiej, wychodziło naprzeciw interesom mieszkańców wsi, pozwalało na uczynienie z gospodarstw drobnotowarowych podstawy rozwoju wsi i rolnictwa.

Obserwacje współczesnego rolnictwa światowego oraz tendencje postępu technicznego w rolnictwie zdają się potwierdzać opinię Grabskiego. Popierał on ten postęp, który miał plonotwórczy charakter. Jest to ten rodzaj postępu technicznego, który przynosi najlepsze efekty w przeludnionym kraju, stojącym

${ }^{82}$ Ibidem, s. 19.

${ }^{83}$ W. Grabski, Ekonomia w produkcji rolnej..., s. 69.

${ }^{84}$ W. Grabski, Ze statystyki rolniczej Królestwa Polskiego w zestawieniu z innymi dzielnicami Państwa Rosyjskiego, Piotrogród 1908, s. 7. 
na niskim poziomie rozwoju. Natomiast mechanizacja w warunkach przeludnionego rolnictwa nie ma sensu. Przede wszystkim mechanizacja nie zwiększa rozmiarów produkcji, przy wysokich kosztach przynosi wzrost kapitałochłonności produkcji, jest więc nie tylko czynnikiem hamującym tempo wzrostu produkcji w skali całej gospodarki, lecz także powodem niskiej efektywności gospodarowania ${ }^{85}$.

Przyjmując założenia o wyłączności procesów dekoncentracji w rolnictwie, Grabski nie był oryginalny. Pogląd ten zdecydowanie przeważał wśród ekonomistów przełomu XIX i XX wieku. Jego zasługa jest natomiast wysunięcie szeregu argumentów, oryginalnych na gruncie polskiej myśli społeczno-ekonomicznej, uzasadniających teorię dekoncentracji. Przeprowadził on także pierwszą w Polsce próbę statystycznej weryfikacji teorii dekoncentracji, która choć nie zakończyła się pełnym sukcesem - stanowiła w latach 30. często wykorzystywany argument popierający tezę o przewadze ekonomicznej gospodarstw chłopskich.

\section{Przeludnienie agrarne. Reforma rolna. Parcelacja}

Jednym z najpoważniejszych problemów gospodarczo-społecznych II Rzeczypospolitej było przeludnienie agrarne (nadmiar rąk do pracy na wsi). W $1935 \mathrm{r}$. szacowano je na 2,4 mln osób ${ }^{86}$.

Przyczyny przeludnienia agrarnego nie tkwiły, zdaniem Grabskiego, w czynnikach demograficznych - wysokim przyroście naturalnym i dużej bezwzględnej gęstości zaludnienia. Grabski słusznie uważał, że przeludnienie agrarne jest skutkiem ukształtowania się czynników ekonomicznych. Twierdził, że Polska nie jest krajem w ogóle przeludnionym, ale w stosunku do ogólnej gęstości zaludnienia zbyt duża jest liczba ludności wiejskiej. Jedną z zasadniczych przyczyn przeludnienia agrarnego widział w wadliwej strukturze gospodarczej, niedorozwoju pozarolniczych gałęzi produkcji ${ }^{87}$. Grabski wiązał przeludnienie

${ }^{85}$ A. Müller, Wybór wytwarzania w rolnictwie krajów ekonomicznie słabo rozwiniętych, [w:] Rolnictwo a wzrost gospodarczy, Warszawa 1966, s. 387-389.

${ }^{86}$ Według Józefa Poniatowskiego, przeludnienie agrarne bezwzględne i względne łącznie wynosiło blisko $5 \mathrm{mln}$ osób czynnych zawodowo (J. Poniatowski, Rozmiary przeludnienia rolnictwa w świetle krytyki, Warszawa 1936; J. Orczyk, Studia nad opłacalnościa gospodarstw rolnych $w$ Polsce w latach 1929-1938, Warszawa 1981).

${ }^{87}$ Te i inne omówione w punkcie niniejszym poglądy, wyraził też Grabski osiem lat później. Stąd wniosek, iż przywiązywał do nich dużą wagę i że stanowiły w jego mniemaniu solidną teoretyczną podstawę do sformułowania metod walki z przeludnieniem agrarnym (patrz: W. Grabski, Przeludnienie wsi i wiejski plan inwestycyjny, „Gospodarka Narodowa” 1936, nr 21). 
agrarne zarówno ze strukturalnym zacofaniem gospodarki polskiej, jak i z niską produktywnością ziemi i pracy. Skrajnie nierównomierny podział ziemi nie był, jego zdaniem, podstawową, tkwiącą w rolnictwie przyczyną bezrobocia na wsi. Zwracał natomiast uwagę na słabość organizacyjną i technologiczną rolnictwa oraz niski poziom kwalifikacji ludności rolniczej.

Generalne rozwiązanie palącej kwestii, jaką było przeludnienie agrarne, widział Grabski w poważnej pracy nad przebudowaniem ,,całej struktury naszego życia ekonomicznego wzwyż do stanu kultury gospodarczej właściwej tym narodom, które nie wiedzą co to przeludnienie, choć mają gęstszą od nas ludność" $"$.

Analizowana $\mathrm{w}$ poprzednim podrozdziale modelowa struktura agrarna Grabskiego była jedną z metod likwidacji przeludnienia w rolnictwie. Szanse bardziej skutecznej walki z jego skutkami dawała zwłaszcza jej zmodyfikowana koncepcja. Zmiany struktury rolnej nie mogły w pełni rozwiązać tego problemu. Jest to zgodna opinia nie tylko autorów przedwojennych, lecz także współczesnych historyków gospodarczych. Zdawał sobie z tego sprawę również Grabski i dlatego uważał, że reforma rolna nie może być jedynym narzędziem likwidacji przeludnienia agrarnego.

W. Grabskiemu zarzucano wielokrotnie, że traktuje problemy rolnictwa z pozycji klasowych, tj. z punktu widzenia ziemiaństwa. Krytyka ta wynikała głównie $\mathrm{z}$ tego, że był on przeciwny radykalnej reformie rolnej. Zasadniczym celem reformy, jego zdaniem, miało być podniesienie poziomu egzystencji ludności wiejskiej. Reforma rolna, w przekonaniu Grabskiego, winna zmniejszyć liczbę rodzin bezrolnych, a powiększyć liczbę gospodarstw samodzielnych. Jej realizację należało przeprowadzić bez ,pierwiastków walki klasowej i metod rewolucyjnych" ${ }^{89}$. Oznaczało to, że uznawał jedynie reformę opartą na ustawie, której podstawą miała być oczywiście zasada odpłatności.

Należy wyraźnie powiedzieć, że Grabski opowiadał się za reformą rolną jeszcze przed odzyskaniem niepodległości. Częściową parcelację uważał za korzystną społecznie dla drobnej własności i dla kraju. Proces ten zmniejszał zawiść społeczną, której przedmiotem była większa własność i dzięki temu osłabiał siłę czynników destrukcyjnych. Opinię tę wyraził Grabski w czerwcu 1918 r..$^{90}$ Obowiązkiem państwa było - jego zdaniem - roztoczenie opieki nad bezrolnymi i służbą dworską.

\footnotetext{
${ }^{88}$ Ibidem, s. 12-13.

${ }^{89}$ W. Grabski, Reforma rolna a moralno-religijny stan ..., s. 8.

${ }^{90}$ W. Grabski, Cele i zadania ..., s. 4.
} 
Będąc ministrem rolnictwa w rządzie Józefa Świeżyńskiego przeforsował wprowadzenie do programu punktu dotyczącego przygotowania reformy rolnej (początek listopada 1918 r.). Zdawał sobie sprawę z konieczności reformy, dostrzegając pogłębiającą się pauperyzację ludności wiejskiej i jej społeczną radykalizację $e^{91}$.

W programie Związku Ludowo-Narodowego (endecja), opracowanym przez braci Grabskich (Stanisława i Władysława), zaakceptowano potrzebę przeprowadzenia umiarkowanych reform społecznych, ze szczególnym uwzględnieniem modyfikacji struktury agrarnej ${ }^{22}$.

W exposé sejmowym wygłoszonym 30.06.1920 r. premier W. Grabski za najważniejsze zadanie ustawodawcze uznał prace nad projektem ustawy o reformie rolnej. Zagrożenie bolszewickie (chodziło o większe zaangażowanie chłopów w wysiłek zbrojny) oraz nastroje rewolucyjne na wsi polskiej ułatwiły Grabskiemu przeforsowanie ustawy o reformie rolnej (18.07.1920 r.). Drugi projekt reformy rolnej (grudzień 1925 r.), która była kompromisem między interesami ziemiaństwa a interesami chłopów (zwłaszcza bogatszych) przyjął Sejm również wtedy, kiedy funkcję premiera pełnił W. Grabski ${ }^{93}$.

Grabski przestrzegał przed radykalną reformą rolną ze względów ekonomicznych i politycznych. Stanowisko w tej kwestii wyraził następująco: „dla Polski reforma, która nie dążyłaby do tego, by obdzielono ziemią chłopów, tak by jak największa liczba rodzin mogła się na niej samodzielnie utrzymać, jest zgubna i niebezpieczna, jest zaczynem fermentów agrarnych groźnych i gorszych od tych, przez jakie przechodziliśmy i przechodzimy"94.

W. Grabski wykazał się w tej drażliwej sprawie nie tylko realizmem i racjonalizmem, lecz także intuicją polityczną. Radykalna reforma rolna PKWN z 1944 r., przeprowadzona w sposób rewolucyjny, nie zadowoliła chłopów, a skrzywdziła właścicieli. Ponadto zmiana struktury agrarnej przez nią spowodowana (powiększenie liczby gospodarstw małorolnych) nie sprzyjała i nadal nie sprzyja wprowadzaniu postępu agrotechnicznego.

Grabski pisał, że „parcelacja nie rozwiązuje problemu, bo dając gospodarstwom możność powiększenia powierzchni, jednocześnie pozbawia

${ }^{91}$ M. M. Drozdowski, Władysław Grabski, Rzeszów-Warszawa 2004, s. 77.

${ }^{92}$ Pisali, że „z ducha moralności chrześcijańskiej” wynika reforma rolna. Musiała ona jednak uwzględniać efektywność gospodarowania, umacniać średnie gospodarstwa chłopskie, zachować równocześnie gospodarstwa folwarczne oraz wzmacniać stan posiadania na Kresach Wschodnich (ibidem, s. 89-90).

${ }^{93}$ J. Skodlarski, Historia gospodarcza, Warszawa 2012, s. 239.

${ }^{94}$ W. Grabski, Mniejsze czy większe..., s. 2. 
pracy bezrolnych i małorolnych. Znaczenie pozytywne parcelacji $\mathrm{w}$ tym względzie polega na tym, że na skutek parcelacji zbytnie zagęszczenie się ludności w pewnych ośrodkach zostaje rozprowadzone po innych. Jest to proces łagodzący" 95 .

Z parcelacji wyłączał nowoczesne, kapitalistyczne folwarki. Parcelowane winny być jedynie te majątki ziemskie, które nie wytrzymywały konkurencji z gospodarką chłopską. Grabski twierdził, że parcelacja majątków nie przyczyni się $\mathrm{w}$ zasadzie do rozwiązania problemu w skali globalnej, a jedynym jej skutkiem będzie przemieszczenie nadmiernego zagęszczenia ludności do innych obszarów ${ }^{96}$.

W. Grabski słusznie łączył przeludnienie z zacofaniem strukturalnym i technologicznym. Zalecał w związku z tym techniczno-organizacyjne środki jego likwidacji poprzez rozwój oświaty, nauki, budowę infrastruktury rolniczej itp. Wymagało to jednak dłuższego czasu i znacznych środków finansowych. $\mathrm{Na}$ podkreślenie zasługuje propozycja Grabskiego, aby równocześnie podnosić poziom efektywności sektora rolniczego oraz działać w kierunku unowocześnienia struktury gospodarczej, rozbudowując pozarolnicze gałęzie produkcji ${ }^{97}$.

Jak już poprzednio wspomniano, Grabski był przeciwnikiem przymusowej parcelacji majątków ziemskich. Sugerował pozostawienie jej swobodnej grze sił rynkowych. W istocie odrzucał potrzebę państwowej regulacji tego procesu ${ }^{98}$.

Dopiero pod wpływem wyniszczających gospodarkę polską skutków kryzysu lat 1929-1933 (w rolnictwie do 1935 r.) i zaostrzenia się sprzeczności klasowych na wsi, Grabski opowiedział się za przyspieszeniem procesu parcelacji w ramach ustawy o reformie rolnej z $1925 \mathrm{r} .^{99}$

Zmodyfikowane stanowisko $\mathrm{w}$ tej kwestii przedstawił w odczycie, który wygłosił 14.12.1936 r. w Towarzystwie Ekonomistów i Statystyków Polskich. Posługując się argumentami ekonomicznymi i politycznymi uzasadniał konieczność parcelacji folwarków w Polsce. Nie zalecał jednak całkowitej likwidacji większych gospodarstw rolnych. Podstawowym warunkiem parcelacji

95 Ibidem, s. 11.

96 „Ale przez parcelację rozrzedza się ludność sąsiednich wiosek. Jednocześnie zaś zagęszcza się zaludnienie na reszcie parcelowanego majątku oraz zagęszcza się ono również tam, gdzie udają się bezrolni, którzy uprzednio pracowali na całości i którzy nie kupili gruntu przy parcelacji. Czyli dodatnie znaczenie parcelacji ujawni się nie zawsze - tylko wtedy, gdy nadmierne zagęszczenie zostanie rozproszone na większym terenie" (W. Grabski, Przeludnienie wsi..., s. 45).

${ }^{97}$ W. J. Puliński, Poglady agrarne..., s. 175-176.

${ }^{98}$ W .J. Puliński, Teoria dekoncentracji..., s. 163.

${ }^{99}$ W. Grabski, Parcelacja agrarna... 
musiało być odszkodowanie. Wystąpienie to odbiło się głośnym echem wśród ekonomistów, publicystów i działaczy gospodarczych. Rozwinęła się burzliwa dyskusja. Nie brakowało polemik i głosów krytycznych ${ }^{100}$.

Grabski podjął dyskusję ze zwolennikami zachowania wielkiej własności ziemskiej. Dowodził, że reforma rolna wpłynie dodatnio na podniesienie „stanu moralnego i religijnego wsi”, co wykluczy walkę klasową, tak niebezpieczną dla całego społeczeństwa. Argument ten miał istotne znaczenie i skierowany był głównie do środowisk katolickich, w których narastała świadomość o konieczności przeprowadzenia reformy rolnej. Chodziło zatem o rozproszenie lęków, jakie niosła fama o reformie rolnej: „Kościół, jak i konserwatyści obawiają się przede wszystkim rewolucji i w reformie agrarnej widzą realizowanie jednego z jej powszechnych haseł"101.

W. Grabski traktował rolnictwo integralnie. Twierdził, że podstawowym problemem społecznym w Polsce i na świecie jest, obok kwestii robotniczej, kwestia rolna. Powstanie kwestii agrarnej Grabski wiązał z istnieniem klas społecznych w środowisku wiejskim. Na wsi wyróżniał trzy klasy: chłopów pracujących we własnych gospodarstwach, właścicieli folwarków zatrudniających najemną siłę roboczą i robotników rolnych.

Uważał, że harmonijne funkcjonowanie całej społeczności wiejskiej wymaga pilnego rozwiązania kwestii robotników rolnych. Problemowi egzystencji robotników rolnych poświęcił Grabski wiele uwagi. Już na początku swej kariery naukowej napisał pracę, w której obiektywnie przedstawił ich położenie ${ }^{102}$. Niewątpliwy wpływ na radykalizm sformułowanych $w$ niej postulatów wywarła rewolucja 1905 r. oraz strajki, które uważał za szczególnie zgubne dla funkcjonowania folwarków. Zalecał pewne ustępstwa, aby nie dopuścić do dalszego pogłębienia sprzeczności klasowych. Podkreślał jednak, że ewentualne reformy stosunków pracy winny leżeć w gestii samych zainteresowanych. Twierdził, że ingerencja państwa w stosunki społeczne na wsi powinna ograniczać się do reformy rolnej. Jego zdaniem tym, czym dla robotników jest ustawodawstwo socjalne, tym dla rolników jest reforma rolna ${ }^{103}$.

Nie jest przypadkiem, że do kwestii robotników rolnych powrócił Grabski w okresie ogarniających Polskę strajków chłopskich w 1937 r. W opublikowanym w tym roku artykule wyraził opinię, że robotnicy folwarczni pozostawali najniżej

${ }^{100}$ Z. Landau, J. Tomaszewski, Lata interwencjonizmu państwowego, 1936-1939, Warszawa 1989, s. 260-261; J. Tomaszewski, Trzy projekty Władystawa Grabskiego, „Kwartalnik Historyczny” 1969, nr 4, s. 1178-1181.

${ }^{101}$ W. Grabski, Reforma rolna a moralno-religijny stan ..., s. 8-9.

102 W. Grabski, Stosunki stużbowo-robotniczo-rolne w Królestwie Polskim, Warszawa 1906.

${ }^{103}$ W. Grabski, Reforma rolna a moralno-religijny stan ..., s. 10. 
w drabinie społecznej. Między nimi a resztą społeczeństwa istniała przepaść, która powodowała powstawanie fermentu klasowego ${ }^{104}$. Budzi tu jedynie wątpliwość zdecydowane oddzielenie pozycji społecznej robotników rolnych od właścicieli gospodarstw karłowatych. Grabski uważał, że nawet niewielka własność ziemska podnosi znacznie pozycję jej posiadacza. Opinii tej przeczy wniosek sformułowany przez Józefa Chałasińskiego (na podstawie badań ankietowych), że robotnicy rolni i biedni chłopi znajdują się na jednakowym poziomie społecznego uznania ${ }^{105}$.

W. Grabski podkreślał, że robotnicy rolni zostali zdegradowani do roli narzędzi; dostrzegał wyraźne pozostałości reliktów pańszczyźnianych w relacjach między robotnikami a obszarnikami. Ostrzegał, że było to powodem, dla którego w $1920 \mathrm{r}$. robotnicy rolni wyraźnie sprzyjali bolszewikom ${ }^{106}$. Przypominał dość często destrukcyjne skutki rewolucji październikowej w Rosji: „Rewolucja agrarna była tą siłą, która powaliła «Rosyjskie Imperium». [...] Stosunki rolne zniszczyły (chodzi o wojnę polsko-bolszewicką) siły prężnie tryumfującego bolszewizmu rosyjskiego"107.

Aby nie dopuścić do pogłębiania antagonizmów na wsi, Grabski przedstawił program poprawy pozycji społecznej robotników. Wyjście z trudnej sytuacji dostrzegał $\mathrm{w}$ reformie rolnej, która swym zasięgiem powinna objąc proletariat wiejski. Twierdził, że tylko w ten sposób można rozwiązać nabrzmiałą w Polsce kwestię agrarną ${ }^{108}$. Brak własnego gospodarstwa będzie zawsze upośledzał robotników folwarcznych w społeczności wiejskiej. Tylko ziemia, którą otrzymają na własność, może stworzyć z robotników rolnych pełnoprawnych obywateli $\mathrm{kraju}^{109}$. Postulat Grabskiego wychodził naprzeciw dążeniom robotników rolnych, którzy marzyli o posiadaniu gospodarstwa rolnego, widząc w nim szansę zabezpieczenia swej egzystencji ${ }^{110}$.

Grabski był przeciwnikiem ustawodawstwa socjalnego, ingerującego w stosunki między właścicielem folwarku a robotnikiem najemnym. Uważał, że rodzi to wzajemną nieufność i ferment między wielką własnością a robotnikami

${ }^{104}$ Ibidem.

105 J. Chałasiński, Drogi awansu spolecznego robotnika, Poznań 1931. Obejmowała ona tylko rejon byłego zaboru pruskiego i opierała się na materiale ankietowym z lat 1921-1922, dotyczącym okresu sprzed I wojny światowej.

${ }^{106}$ W. Grabski, Reforma rolna a moralno-religijny stan ..., s. 11.

${ }^{107}$ W. Grabski, Społeczne gospodarstwo agrarne w Polsce, Warszawa 1923, s. 5.

${ }^{108}$ W. Grabski, Reforma rolna a moralno-religijny stan..., s. 11.

${ }^{109}$ Ibidem, s. 8 i 11.

110 J. Chałasiński, op.cit., s. 142. Wielu z tych, którzy nabyli gospodarstwo karłowate przeżyło rozczarowanie. 
rolnymi. Dostrzegał wprawdzie niedolę robotników folwarcznych i widział naglącą potrzebę poprawy ich sytuacji materialnej, postulował m.in. poprawę warunków mieszkaniowych, organizację opieki lekarskiej, podniesienie płac, zabezpieczenie na starość i na wypadek niezdolności do pracy, ale realizacja tych postulatów miała nastąpić dzięki dobrowolnym decyzjom pracodawców ${ }^{111}$. Poglądów swych nie zmienił właściwie do końca życia. W 1935 r. pisał, że „rozszerzenie na robotników folwarcznych ustawodawstwa socjalnego stworzyło drugą legalną klasę robotniczą i klasę właścicieli folwarków" "112. Osiągnięto zatem odwrotny od pożądanego skutek, zamiast osłabić klasowość wsi, pogłębiano ją.

Postulaty wysuwane przez W. Grabskiego w celu poprawy położenia ekonomicznego i społecznego ludności wiejskiej oraz wprowadzenia gospodarki polskiej na ścieżkę przyspieszonego rozwoju tworzyły spójny i logiczny system polityki agrarnej. Grabski słusznie uważał, że system ten musi być oparty na solidnych naukowych podstawach. Rozumiał potrzebę i podejmował próby kompleksowego rozwiązania podstawowych problemów gospodarczych i społecznych Polski. Widział konieczność spełnienia podstawowych żądań społeczności wiejskiej, podniesienia poziomu jej egzystencji, poziomu oświaty, kultury, był przeciwnikiem dyskryminacji, klasowego upośledzenia chłopów. Jego poglądy na skalę przedsiębiorstwa rolnego, zakres specjalizacji, stosowaną technikę rolniczą były racjonalne z punktu widzenia warunków funkcjonowania rolnictwa polskiego.

${ }^{111}$ W. Grabski, Stosunki stużbowo-robotniczo-rolne..., s. 97.

112 W. Grabski, Idea Polski..., s. 95. 



\section{Podsumowanie}

Władysław Grabski znany jest przede wszystkim jako wybitny reformator gospodarki polskiej i socjolog wsi. Nie ukazało się dotąd opracowanie dotyczące jego poglądów makroekonomicznych. Zajmował się teorią ekonomii wówczas, gdy realizował zadania z zakresu praktyki gospodarczej. Wychodził od stwierdzeń teoretycznych i przechodził do praktyki ekonomicznej. W związku z powyższym poglądy ekonomiczne Grabskiego są w większości nadal aktualne i warto je zaprezentować dzisiaj, w naszej skomplikowanej rzeczywistości gospodarczej.

Przygotowując niniejszą publikację, autor przeprowadził kwerendę w Archiwum Akt Nowych w Warszawie, przeanalizował dorobek naukowy W. Grabskiego oraz skonfrontował jego poglądy z poglądami akademickich ekonomistów.

Na szczególną uwagę zasługują poglądy Grabskiego dotyczące relacji rynek - państwo, czynników kreujących dochód narodowy, podatków, budżetu i pieniądza.

Opowiadał się zdecydowanie za wolnością gospodarczą i prymatem rynku $\mathrm{w}$ gospodarce. Funkcje ekonomiczne państwa powinny - jego zdaniem ograniczać się do ściśle koniecznych zadań. Najważniejszym czynnikiem wzrostu gospodarczego, według Grabskiego, były inwestycje, zwłaszcza przeznaczone na rozbudowę infrastruktury oraz na naukę i oświatę. Podkreślał szczególną rolę pracy w tworzeniu dochodu narodowego, zwłaszcza pracy wykwalifikowanej. Zalecał, aby podatki były rozkładane sprawiedliwie. Unikanie płacenia podatków przez właścicieli uważał za zjawisko wysoce naganne.

Premier Grabski uważał, że podstawą dobrze funkcjonującego państwa jest równowaga budżetowa. Powtarzał często, że jest to „twarda konieczność, ale konieczność". Był zwolennikiem zdrowej i silnej waluty opartej na złocie. Dewaluację złotego uznawał za posunięcie szkodliwe dla gospodarki polskiej. Pogląd ten, jak wiadomo, nie wytrzymał próby czasu. 
Na wysoką ocenę zasługują poglądy agrarne W. Grabskiego. Ich wartość podnosi umiejętne połączenie teorii $\mathrm{z}$ praktyką. Opracował on teorię dekoncentracji w rolnictwie oraz koncepcję struktury agrarnej, którą można było zastosować w praktyce. Wniósł wkład do teorii kryzysów w rolnictwie, a także przedstawił środki zaradcze, służące ich zwalczaniu.

W. Grabski, poszukując optymalnego modelu struktury agrarnej, przeprowadził głęboką analizę poszczególnych typów gospodarstw w Polsce. Na jej podstawie uzasadnił teorię dekoncentracji na gruncie polskim. Właściwa struktura agrarna obejmowałaby, jego zdaniem, gospodarstwa zaspokajające potrzeby konsumpcyjne rodziny chłopskiej oraz gospodarstwa produkujące nadwyżki. Wymóg ten spełniały większe gospodarstwa chłopskie i część kapitalistycznych folwarków. Stanowić one miały podstawę idealnej struktury agrarnej.

Licząc się $\mathrm{z}$ realiami polskiego rolnictwa, przygotował alternatywną koncepcję struktury agrarnej - jedynie możliwą do przyjęcia w polskich warunkach. Do zmiany stanowiska skłoniło go przede wszystkim przeludnienie agrarne. $\mathrm{Z}$ tego powodu uznał, że podstawą struktury rolnej powinny być samodzielne gospodarstwa chłopskie, koegzystujące $\mathrm{z}$ folwarkami o wysokiej efektywności.

W. Grabski był przekonany, że rolnictwo polskie będzie w sposób naturalny ewaluować w kierunku wydajnego rolnictwa krajów zachodnich. Przestrzegał przed kolektywizacją w wydaniu sowieckim. Nowe podejście zaprezentował w kwestii badań dotyczących kryzysów w rolnictwie. Należało, jego zdaniem, uwzględniać więcej czynników niż w przemyśle, zwłaszcza zwracać większą uwagę na uwarunkowania przyrodnicze. Wyrażał przekonanie, że koniunkturę w rolnictwie powinno rozpatrywać się w powiązaniu ze zmianami dotyczącymi produkcji przemysłowej. Na podstawie bogatej statystyki dowiódł, że kryzys w rolnictwie może mieć zasięg światowy, może dotyczyć kilku państw, jednego kraju, bądź też ograniczać się do niektórych płodów rolnych, np. buraków cukrowych, żyta, pszenicy itp.

W. Grabski, zdając sobie sprawę ze słabości polskiego rolnictwa, zalecał zmiany polityki agrarnej, podniesienie poziomu egzystencji społeczności wiejskiej oraz rozwój nauki, oświaty i kultury. 


\section{Bibliografia}

\section{I. Źródła archiwalne}

Archiwum Akt Nowych w Warszawie.

Akta Władysława Grabskiego, sygn. III-9, 1, 2, 7, 15, 16, 17, 22, 25.

Biblioteka Narodowa w Warszawie. Dział rękopisów, sygn. 9751/I-V.

\section{Prace Wladysława Grabskiego}

Cele i zadania polityki agrarnej w Polsce, Warszawa 1918.

Celowy Związek Inwestycyjny Samorządów Powiatowych, Warszawa 1928.

Czy należy wprowadzać nowego złotego?, „Drogi Naprawy” 1928, nr 2.

Dwa lata pracy u podstaw państwowości naszej (1924-1925), Warszawa 1927; Lublin 2004.

Ekonomia rolnicza gospodarstw mniejszych, Warszawa 1910.

Ekonomia w produkcji rolnej, [w:] W naszych sprawach, t. 1, Warszawa 1900.

Historia Towarzystwa Rolniczego, t. 1-2, Warszawa 1904.

Historia wsi w Polsce, Warszawa 2004.

Idea Polski, Warszawa 1935.

Koniunktura, kryzysy i rozwój gospodarczy, Warszawa 1929.

Kryzysy rolnicze światowe i kryzys w Polsce, Warszawa 1930.

Kultura wsi polskiej i nauczanie powszechne, Warszawa 1929.

La crise agricole en Europe, Warszawa 1931.

Materiały w sprawie włościańskiej, t. 1, Warszawa 1907.

Melioracje rolne w czasie kryzysu rolnego, „Rolnictwo” 1933/1934, T. I, z. 3.

Mniejsze czy większe gospodarstwa włościańskie przy reformie rolnej, Warszawa 1937.

Myśli o Rzeczypospolitej. Autonomia, reforma, edukacja obywatelska. Wybór myśli politycznych i społecznych, wyb. i wstęp M. M. Drozdowski, Kraków 1988. 
Najszkodliwszy z etatyzmów, „Drogi Naprawy” 1926, nr 3.

O potrzebie napisania historii rozwoju nauki o spolecznem gospodarstwie agrarnem wśród narodów słowiańskich, odb. ze Sprawozdania z posiedzenia Towarzystwa Naukowego Warszawskiego XXVI. 1933, Warszawa 1933.

O wtasnych siłach, Warszawa 1925.

Parcelacja agrarna wobec struktury, koniunktury $i$ chwili dziejowej Polski, „Ekonomista” 1936, T. IV.

Podstawy sity wewnętrznej państwa polskiego. Materiaty i studia w sprawie odbudowy Państwa Polskiego, Piotrogród 1917.

Polityka ekonomiczna. Skrypt z wykładów Prof. Władysława Grabskiego, Warszawa 1938.

Program walki z kryzysem gospodarczym w Polsce, Warszawa 1925.

Projekt programu polityki ekonomicznej i finansowej po wojnie, Warszawa 1920.

Przeludnienie wsi i wiejski plan inwestycyjny, „Gospodarka Narodowa” 1936, nr 21.

Reforma agrarna wstecz, Warszawa 1929 [odb. z „Rolnika Ekonomisty”].

Reforma oddlużenia rolniczego na skutek wzrostu cen rolniczych, „Przegląd Ekonomiczny" 1937, T. XVII.

Reforma rolna a moralno-religijny stan wsi, Warszawa 1937.

Rola społeczna obywatela wiejskiego, [w:] W. Grabski, W naszych sprawach, Warszawa 1899.

Równowaga budżetowa w świetle sytuacji gospodarczej, Warszawa 1924.

Równowaga budżetu i konieczności państwowe, „Drogi Naprawy” 1927, nr 6.

Rząd wobec kryzysu gospodarczego, Warszawa 1925.

Społeczne gospodarstwo agrarne w Polsce, Warszawa 1923.

Stosunki stużbowo-robotniczo-rolne w Królestwie Polskim, Warszawa 1906.

System socjologii wsi, cz. II, ,Roczniki Socjologii Wsi” 1937, T. II.

Wewnętrzny rynek zbytu, ,Rolnik Ekonomista” 1933, nr 21.

Wiedza a praktyka rolnicza w Niemczech, „Ateneum” 1897, T. III.

Wieś i folwark, Warszawa 1930.

Wieś jako siła społeczna, „Rolnictwo” 1936, T. II, z. 2.

Wieś polska i kapitalizm w rolnictwie, „Ekonomista” 1930, T. IV.

Wieś polska na tle rewolucji dziejowej, Warszawa 1929.

Wybór pism, Warszawa 1987.

Zagadnienia polskiej polityki ekonomicznej, cz. 3 i 4, Warszawa 1929.

Zagadnienie postęu rolniczego wobec kryzysu, Warszawa 1930. 
Ze statystyki rolniczej Królestwa Polskiego w zestawieniu z innymi dzielnicami Państwa Rosyjskiego, Piotrogród 1908.

Znaczenie czynników psychicznych w produkcji rolnej, Warszawa 1927.

\section{Pozostałe prace i materiały}

Albert A., Najnowsza historia Polski, 1918-1980, Polonia 1989.

Antoniewski A., Z ekonomiki gospodarstw dużych i małych, Warszawa 1938.

Barański L., Uwagi nad obiegiem pieniężnym w Polsce, Warszawa 1926.

Bastiat F., Państwo, [w:] Odkrywając wolność. Przeciw zniewoleniu umystów, wyb. i wstęp L. Balcerowicz, Wydawnictwo Zysk i S-ka, Poznań 2012.

Biegeleisen L. W., Teorya małej i wielkiej własności ziemskiej, Kraków 1918.

Borkowski J., Chłopi polscy w II Rzeczypospolitej, „Najnowsze Dzieje Polski 1914-1939” 1968, T. XIII.

Breit W., Blumenfeld B., Podatek majątkowy, Lwów 1924.

Buszko J., Historia Polski, 1864-1948, Warszawa 1978.

Chałasiński J., Drogi awansu społecznego robotnika, Poznań 1931.

Chałasiński J., Młode pokolenie chłopów, t. 1, Warszawa 1938.

Czaja J., Zmiany cykli koniunkturalnych w Unii Europejskiej oraz ich konsekwencje dla gospodarek krajów członkowskich, [w:] Polityka ekonomiczna. Współczesne wyzwania, red. M. Klamut, Warszawa 2007.

Dokumenty do dziejów Państwowego Banku Rolnego, t. 1: 1938-1944, wstęp i oprac. M. Kłusek.

Drozdowski M. M., Wielka reforma antyinflacyjna Władysława Grabskiego i jej skutki, [w:] Władysław Grabski. Człowiek i dzieła, Łowicz 1994.

Drozdowski M. M., Władysław Grabski, Rzeszów-Warszawa 2004.

Duda S., Przedmiot i metoda ekonomii w ujęciu Stanisława Grabskiego, [w:] Historia gospodarcza $i$ historia myśli ekonomicznej a teoria ekonomii. Problemy metodologiczne, red. J. Skodlarski, Łódź 2008.

Dwa lata pracy u podstaw państwowości naszej (1924-1925), oprac. M. M. Drozdowski, Warszawa-Rzeszów 2003.

Estey J. A., Cykle koniunkturalne, Warszawa 1959.

Fiedor B., Współczesny wzrost gospodarczy - uwarunkowania strukturalne a koniunkturalne oraz potrzeba ,eklektyczna” $w$ teorii $i$ polityce wzrostu, [w:] Polityka ekonomiczna. Współczesne wyzwania, red. M. Klamut, Warszawa 2007. 
Friedman M., Monetary Studies of the National Bureau, przedruk, [w:] M. Friedman, The Optimum Quantity of Money and Other Essays, Chicago 1969.

Garlicki A., Historia, 1815-2004, Polska i świat, Warszawa 2005.

Gazzaaniga M. S., Przyrodniczy umyst, [w:] Odkrywajac wolność. Przeciw zniewoleniu umysłów, wyb. i wstęp L. Balcerowicz, Wydawnictwo Zysk i S-ka, Poznań 2012.

Godłów-Legiędź J., Doktryna społeczno-ekonomiczna Friedricha von Hayeka, Warszawa 1992.

Górski J., Polska myśl ekonomiczna a rozwój gospodarczy, Warszawa 1963.

Grabski J. W., Blizny dzieciństwa, Warszawa 1971.

Grabski S., Ekonomia społeczna, cz. I-X, Lwów 1927-1933.

Grabski S., Zur Erkenntnischie der Volkswirtschaflichen Erscheinungen (Przyczynek do nauki o poznaniu zjawisk gospodarczo-narodowych), Berno 1900.

Gruszecki T., Reforma pieniężna W. Grabskiego. Ile warta jest stabilizacja pieniądza?, [w:] Władysław Grabski. Uczony i mąż stanu, Lublin 2005.

Heady E. O., Economics of Agricultural Production and Resource Use, New York 1925.

Hansen A. H., Business Cycles Theory, Boston 1927.

Kalecki M., Landau L., Szacunek dochodu społecznego w roku 1929, Warszawa 1934.

Kautsky K., Kwestia agrarna, Warszawa 1958.

Keynes J. M., Ogólna teoria zatrudnienia, procentu i pieniądza, Warszawa 1956.

Keynes J. M., Treatise on Money, t. 1, New York 1930.

Kłusek M., Konwersja zadłużenia rolniczego jako element walki państwa z kryzysem $w$ rolnictwie $w$ Polsce międzywojennej, „Roczniki Naukowe Stowarzyszenia Ekonomistów Rolnictwa i Agrobiznesu" 2009, T. I, z. 2.

Kłusek M., Uruchomienie kredytu warrantowo-lombardowego, „Roczniki Naukowe Stowarzyszenia Ekonomistów Rolnictwa i Agrobiznesu” 2007, T. IX, z. 4.

Knakiewicz Z., Deflacja polska, Warszawa 1967.

Korab K., Władysław Grabski, Warszawa 2004.

Korab K., Władysław Grabski jako socjolog wsi, Warszawa 2004.

Koźniewski A., Czasowe obniżanie składek w ubezpieczeniach społecznych, „Przegląd Ubezpieczeń Społecznych" 1937, nr 8.

Krzyżanowski A., Dolar i złoty, Kraków 1936.

Krzyżanowski A., Polityka i gospodarstwo, Kraków 1931.

Krzyżanowski A., Trzy systemy polityki walutowej, „Przegląd Gospodarczy” 1932, z. 14.

Kwiatkowski E., Rekonstrukcja gospodarcza Polski, Warszawa 1929. 
Landau Z., Podatek majątkowy, [w:] Encyklopedia historii gospodarczej Polski do 1945 r., Warszawa 1981.

Landau Z., Polityczne aspekty działalności angielskiej misji doradców finansowych E. Hiltona Younga w Polsce (1923-1924), „Zeszyty Naukowe Szkoły Głównej Planowania i Statystyki” 1958, nr 9.

Landau Z., Pożyczki zagraniczne państwa polskiego, 1918-1939, „Finanse” 1969, nr 6.

Landau Z., Roszkowski W., Polityka gospodarcza II RP i PRL, Warszawa 1995.

Landau Z., Tomaszewski J., Gospodarka Polski międzywojennej 1918-1939, t. 1: W dobie inflacji 1918-1923, Warszawa 1967.

Landau Z., Tomaszewski J., Lata interwencjonizmu państwowego, 1936-1939, Warszawa 1989.

Landau Z., Tomaszewski J., Od Grabskiego do Pitsudskiego. Okres ożywienia koniunktury 1924-1929, Warszawa 1971.

Landau Z., Tomaszewski J., Zarys historii gospodarczej Polski, 1918-1939, Warszawa 1962.

Luszniewicz J., Druga Rzeczpospolita. Wrrost podporządkowany integracji $i$ modernizacji gospodarczej, [w:] Polskie osiagnięcia gospodarcze, red. J. Kaliński, Warszawa 2010.

Luszniewicz J., Wahania koniunktury a geneza, rozwój i kryzys keynesizmu. Refleksje historyczno-gospodarcze, [w:] Koniunktura gospodarcza a narodziny, wzrost $i$ upadek wielkich doktryn ekonomicznych. Księga pamiątkowa w 50-lecie śmierci profesora Andrzeja Grodka, red. J. Łazor, W. Morawski, Warszawa 2011.

Łychowski T., Rozwój systemów clearingowych, „Polska Gospodarcza” 1938, nr 4.

Maty Rocznik Statystyczny 1939, Warszawa 1939.

„Miesięczne Tablice Statystyczne” 1938, nr 7.

Mieszczankowski M., Struktura agrarna Polski międzywojennej, Warszawa 1960.

Miłkowski S., Agraryzm jako forma przebudowy ustroju społecznego, Kraków 1934.

Mitchell W. C., Business Cycles, The Problem and Its Setting, New York 1927.

Młynarski F., Wspomnienia, Warszawa 1971.

Müller A., Wybór wytwarzania w rolnictwie krajów ekonomicznie słabo rozwiniętych, [w:] Rolnictwo a wzrost gospodarczy, Warszawa 1966.

Niskanen W. A., Państwo opiekuńcze i kultura ubóstwa, [w:] Odkrywając wolność. Przeciw zniewoleniu umysłów, wyb. i wstęp L. Balcerowicz, Wydawnictwo Zysk i S-ka, Poznań 2012.

Orczyk J., Studia nad opłacalnościa gospodarstw rolnych w Polsce w latach 1929-1938, Warszawa 1981. 
Piątkowski W., Myśl agrarystyczna Stanisława Miłkowskiego, Warszawa 1983.

Pigou A. C., Industrial Fluctuations, London 1913.

Pobóg-Malinowski W., Najnowsza historia polityczna Polski, 1864-1945, t. 2, cz. 1, Londyn 1956.

Podolska-Meducka A., Od wojny do wojny. System świadczeń wojennych $w$ Polsce w latach 1918-1921, Warszawa 2011.

Polskie osiagnięcia gospodarcze, red. J. Kaliński, Warszawa 2010.

Poniatowski J., Rozmiary przeludnienia rolnictwa w świetle krytyki, Warszawa 1936.

Ponikowski W., Badania porównawcze gospodarstw wiejskich rozmaitych wielkości lub rozmaitych typów pracy, „Roczniki Nauk Rolniczych i Leśnych” 1934, T. XXIII.

Puliński W. J., Poglądy agrarne Władysława Grabskiego, praca doktorska, Łódź 1979, Biblioteka Uniwersytetu Łódzkiego.

Puliński W. J., Struktura agrarna a rozwój gospodarczy $w$ pracach Władysława Grabskiego, „Acta Universitatis Lodziensis” 1982, Folia oeconomica 19.

Puliński W. J., Teoria dekoncentracji jako ekonomiczna przesłanka agraryzmu w pogladach Władysława Grabskiego, „Roczniki Dziejów Ruchu Ludowego” 1983/1984.

Puliński W., Władysław Grabski jako historyk i ekonomista, [w:] Historia gospodarcza $i$ historia myśli ekonomicznej a teoria ekonomii. Problemy metodologiczne, red. J. Skodlarski, Łódź 2008.

Ritter K., Tendencje rozwojowe rolnictwa światowego, „Rolnictwo”, wrzesień 1929.

„Rocznik Statystyczne Królestwa Polskiego”. Dopełnienie do roku 1914, oprac. pod kierunkiem W. Grabskiego, Piotrogród 1915.

Roszkowski W., Gospodarcza rola większej prywatnej własności ziemskiej w Polsce, 1918-1939, Warszawa 1986.

Samuelson P. A., Nordhaus W. D., Ekonomia 1, Warszawa 1995; Ekonomia 2, Warszawa 1996.

Schmidt S., Problemy związane z naprawa ustroju rolnego, „Ekonomista” 1938, T. II.

Schumpeter J .A., Business Cycles, New York 1939.

Skodlarski J., Historia gospodarcza, Warszawa 2012.

Skodlarski J., Wybitni reformatorzy $i$ kreatorzy polskiego pieniądza a ich oblicze moralne, t. 1, Łódź 2009.

Skodlarski J., Zarys historii gospodarczej Polski, Warszawa-Łódź 2000.

Stecki J., Reforma rolna a kapitalizacja, „Przegląd Ekonomiczny” 1937, T. XVIII.

Styś W., Rolnictwo a uprzemystowienie, Lwów 1938. 
Sułkowska W., Twórcy polskiej myśli ekonomicznej: Władysław Grabski, Kraków 1990.

Szultz T. W., Agriculture in an Unstable Economy, New York 1945.

Tanzi V., Gospodarcza rola państwa w XXI wieku, [w:] Odkrywając wolność. Przeciw zniewoleniu umysłów, wyb. i wstęp L. Balcerowicz, Wydawnictwo Zysk i S-ka, Poznań 2012.

Thomas W., Znaniecki F., Chłop polski w Europie i Ameryce, Warszawa 1976.

Thorp W. L., Business Annals, New York 1926.

Tomaszewski J., Trzy projekty Władysława Grabskiego, „Kwartalnik Historyczny” 1969, nr 4.

Turczynowicz S., Z zagadnień polityki melioracyjnej w Polsce, „Rolnictwo” 1933/1934, z. 3.

Wierzbicki A., Wielka reforma, [w:] Wspomnienia i relacje o reformach Władystawa Grabskiego, wyb. i oprac. M. M. Drozdowski.

Wójtowicz G., Wójtowicz A., Historia monetarna Polski, Warszawa 2003.

Zarys historii Polski, red. J. Tazbir, Warszawa 1980.

Zawadzki W., Wykład o polityce finansowej, „Polska Gospodarcza” 1934, z. 19.

Żabko-Potopowicz A., Ś.p. prof. Władysław Grabski, „Ekonomista” 1938, nr 1.

Żabko-Potopowicz A., Zagadnienie najkorzystniejszego stosunku między gospodarstwami wiejskimi różnych rozmiarów w polskiej literaturze naukowej, „Ekonomista” 1937, T. III.

Żurawicki S., Myśl ekonomiczno-polityczna w Polsce okresu międzywojennego, Warszawa 1970.

\section{Prasa}

„Drogi Naprawy” 1926.

„Express” 1923.

„Gazeta Poranna” 1924.

„Kurier Warszawski” 1926, 1927.

„Nowiny Finansowe” 1923.

„Strażnica Polska” 1923 



\section{INDEKS OSÓB}

W indeksie nie uwzględniono nazwiska Władysława Grabskiego

\section{A}

Abramowski Edward 11

Antoniewski Stanisław 120, 121

B

Balukiewicz B. 87

Barański Leon 53

Bastiat Frédéric 45

Biegeleisen Leon W. 120, 121

Brzostowski Paweł 43

Burek 70

C

Chałasiński Józef 130

Chmielowski Piotr 11

Chrzanowski Ignacy 11

Curzytek J. 117

D

Dawid Jan Władysław 11

Dmowski Roman 17

Drozdowski Marian M. 12, 19

Drucki-Lubecki Ksawery 15

E

Estey James Arthur 57, 60

F

Fiedor Bogusław 78
G

Grabski Andrzej Rafał 9, 13

Grabski Feliks 9, 10

Grabski Franciszek 9

Grabski Jan Władysław 10, 13

Grabski Stanisław 9, 10

Grabski Wacław 13

Grabski Zdzisław 13

H

Hayek Friedrich von 60

J

Jabłonowska Anna 43

Jaroński Wiktor 16

Juglar Clement 57

K

Kalecki Michał 36

Karpiński Stanisław 23

Katarzyna z Lewandowskich 13, 14

Kemmerer Edwin W. 25, 26, 52, 53, 88

Keynes John M. 34, 60

Kirkor-Kiedroniowa Zofia 10

Knakiewicz Zenobia 49, 54

Korab Kazimierz 7, 11, 32

Korzon Tadeusz 11 
Krzywicki Ludwik 11, 111

Krzyżanowski Adam 53, 54

Kucharski Władysław 21

Kwiatkowski Eugeniusz 88

L

Landau Ludwik 36, 54

Lavisse E. 12

Leroy-Beaulieu P. 12

Linde Herbert I. 21

Ludkiewicz Zdzisław 121

M

Mahrburg Adam 11

Marks Karol 32, 33, 63, 64

Michalski Jerzy 21

Mikołajewicz Mikołaj 16

Mittelstaed Stanisława 9, 10

$\mathbf{N}$

Nordhaus William D. 29

$\mathbf{P}$

Paderewski Ignacy 17

Piłsudski Józef 17, 24

Poniatowski Juliusz 121

Ponikowski Wacław 121

Puliński Włodzimierz J. 111

$\mathbf{R}$

Radwan Władysław 41

Ritter Kurt 67

Roszkowski Wojciech 121

Rybarski Roman 20, 121

$\mathbf{S}$

Samuelson Paul A. 29
Say Leon 11

Schmidt Stefan 70

Seignobs Charles 12

Sienkiewicz Henryk 14, 29

Sikorski Władysław 20

Skulski Leon 17

Smoleński Władysław 11

Sondel Jan K. 121

Sorel Albert 11

Sosnkowski Kazimierz 19

Staniewicz Witold 121

Stolarski Błażej 121

Ś

Świeżyński Józef 17, 127

$\mathbf{T}$

Tanzi Vito 44

Thomas W. 111

Tomaszewski Jerzy 54

W

Wawrzyniak Piotr 13

Wierzbicki Andrzej 22, 25

Witos Wincenty 20, 21, 24, 25

Wojciechowski Stanisław 19, 20, 22, 23

Wojnarowski Jan 11

$\mathbf{Y}$

Young Hilton E. 25, 110

$\mathbf{Z}$

Zamojski Andrzej 43

Znaniecki Florian 111

$\dot{\mathbf{Z}}$

Żabko-Potopowicz Antoni 26, 29, 121 